G. PIRUMYAN, G. SIMONYAN, L. MARGARYAN

\title{
GEOECOLOGICAL EVALUATIONAL INTEGRATING INDEX OF NATURAL WATERS AND OTHER SYSTEMS
}




\section{Reviewers:}

Gheorghe Duca - President of NAS of the Republic of Moldova, Doctor of Science (Chemistry), professor

Armen Trchunyan - Correspondent Member of the NAS of the Republic of Armenia, Doctor of Science (Biology), professor Robert Minasyan - Doctor of Science (Geology), professor

Gevorg Pirumyan - Academician of RANS, Doctor of Science (Technical Sciences), professor

Gevorg Simonyan - Academician of IIA, Professor of RANH, Ph.D. (Chemistry), associate professor

Liana Margaryan - Doctor of Science (Technical Sciences), associate professor

Pirumyan G., Simonyan G., Margaryan L.

Geoecological Evaluational Integrating Index of Natural Waters and other Systems/ G. Pirumyan, G. Simonyan, L. Margaryan. -Yerevan, 2019, $244 \mathrm{p}$.

Monography is dedicated to determination and assessment of fresh water quality taking into consideration their hydrochemical indicators. Development of the Armenian indexes of water quality is based upon the results of the authors' investigations. On the suggestions of the foreign scientists these indexes have been applied for mathematical modelling of the different biosystems and oil as well.

The book is proper for the specialists, post-graduates and students in the fields of hydrology, hydrochemistry, ecosystems, oil and mathematical modelling as well.

ISBN 978-9939-875-29-3

(C) Pirumyan G., 2019

(C) Simonyan G.,2019

(C) Margaryan L., 2019 

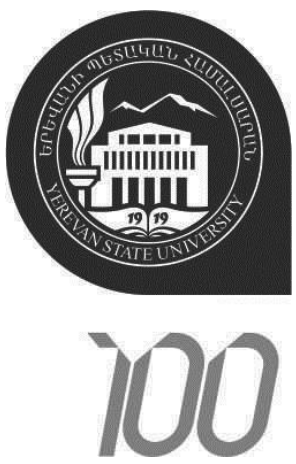

The monography is dedicated to the hundredth anniversary of the Yerevan State University 


\section{Contents}

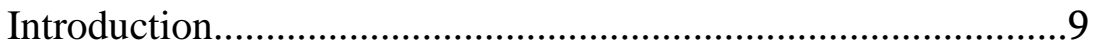

Chapter 1. Natural Water Characterization................................ 11

1.1 Representation about anomalous and specific properties of

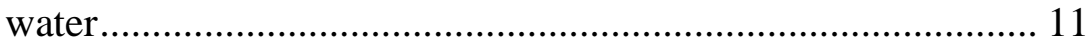

1.2 Assessment of Natural Water Quality................................ 18

1.2.1 Surface water ............................................................ 18

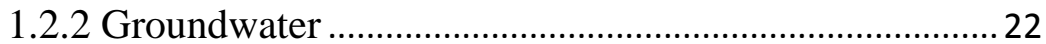

1.3 Study of the hydrochemical regime of natural water in the Republic of Armenia ............................................. 27

Chapter 2. Assessment of natural water quality......................... 31

2.1 Assessment of water quality through the water quality norms

2.2 New approaches for integrated assessment of natural water quality 35

2.3 Antropogenic Impact on water quality of natural water resources

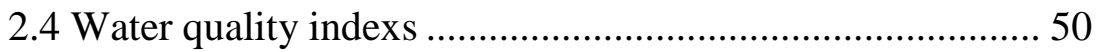

2.4.1 Horton Water Quality Index (HWQI) ........................... 52

2.4.2 National Sanitation Foundation Water Quality

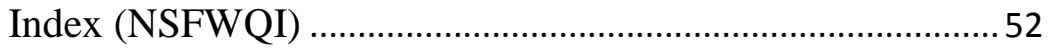

2.4.3 Canadian Council of Ministers of the Environment

Water Quality Index (CWQI).................................................. 54

2.4.4 British Columbia Water Quality Index (BCWQI)........55

2.4.5 Modified Canadian Water Quality Index

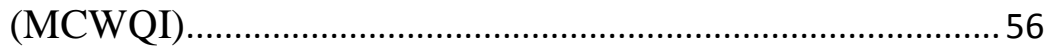

2.4.6 Oregon Water Quality Index (OWQI) ........................... 57

2.4.7 Malaysia Water Quality Index (MWQI) .........................59 
2.4.8 Dinius Water Quality Index (DWQI) .............................. 59

2.4.9 Bascarón Water Quality Index (BWQI) ......................... 60

2.4.10 Scottish Research Development Department

Water Quality Index (SWQI) ................................................... 61

2.4.11 Taiwan Water Quality Index (TWQI). River

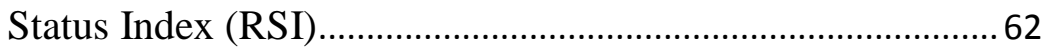

2.4.12 Overall Index of Pollution (OIP) .................................... 64

2.4.13 Bhargava Method Water Quality Index

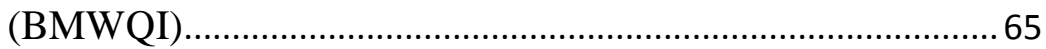

2.4.14 Smith's Water Quality Index (SWQI) ..........................66

2.4.15 Aquatic toxicity Water Quality Index (ATWQI) ....... 67

2.4.16 The River Ganga Index of Ved Prakash et al

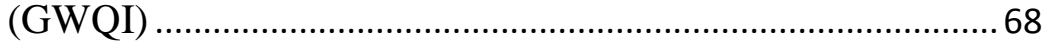

2.4.17 Catalan Water Agency Water Quality Index

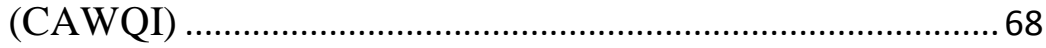

2.4.18 Universal Water Quality Index (UWQI) .......................69

2.4.19 Fuzzy Water Quality Index(FQWI) ............................ 70

2.4.20 Weighted Arithmetic Water Quality Index

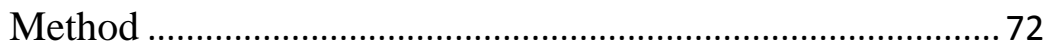

2.4.21 Water Contamination Index (WCI) ............................... 73

2.4.22 Specific Combinatory Water Quality Index

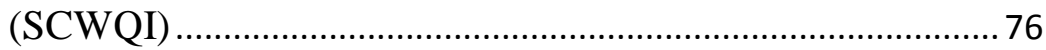

2.4.23 The Model of Flow Transferring Substance's

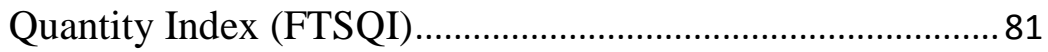

2.5 Examples of the Rivers' water quality assessment ............. 85

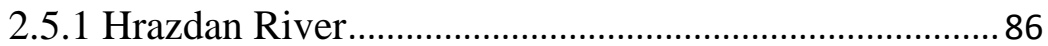

2.5.2 Akhuryan River ....................................................... 91 


\subsubsection{Sevdjur (Metsamor) River and its tributary}

Kasakh River .................................................................... 94

2.5.4 Reservoirs in Armenia.................................................... 98

2.6. Assessment of anthropogenic pressure on water qaulity of Sevdjur, Kasakh and Hrazdan rivers ........................ 99

2.7 Assessment of groundwater quality ................................. 106

Chapter 3. New proposed indexes ......................................... 116

3.1 Entropic Water Quality Index (EWQI) and Armenian Water Quality Index (AWQI) ..................................................... 116

3.1.1 Hydrological characterization of the Debed river

basin 118

3.1.2 The rivers Agstev and Getik ........................................ 122

3.1.3 Rivers Vorotan, Goris and Sisian ................................. 123

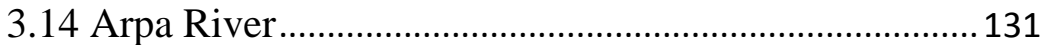

3.1.5 Rivers Voghji, Artsvanik and Geghi ............................ 134

3.1.6 Rivers Akhuryan, Ashotsk and Karkachun .................. 137

3.17 Water Quality Indexes for Rivers Sevdjur,

Kasakh and Aparan................................................................. 141

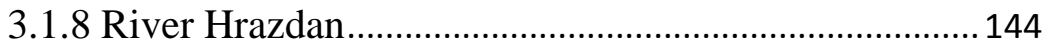

3.1.9 Lake Sevan........................................................ 147

3.1.10 The ecological status of reservoirs in Armenia ........ 149

3.2 Method on Integrated assessment of Natural Water

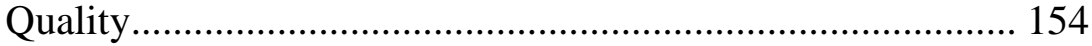

3.3 New method for natural Water Quality Prediction based on climate change scenarios

3.3.1 Prediction of the quality of natural water according to

the concentration of the hydrochloric acid ............................ 169 
Chapter 4. Natural Water Quality Assessment Methods 178 4.1 New system for surface water quality assessment in Armenia, based on EU WFD ................................................ 178

4.2 Water quality assessment of Debed River 182

4.3 Europian water quality indexes with biological content

4.3.1 Hulberts diversity index (ES100) ............................... 187

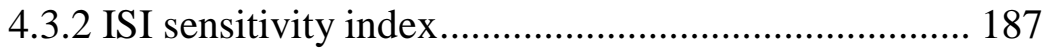

4.3.3.The Applied Marine Biotic Index (AMBI) ............... 188

4.3.4 Norwegian quality index version 1 (NQI1)............... 189

4.3.5 The Norwegian quality index version 2 (NQI2) ....... 190

4.3.6 The Danis index (DKI)................................................ 190

4.3.7 Infaunal quality index (IQI) ..................................... 191

4.3.8 Benthic quality index (BQI ) .................................... 191

4.3.9 Benthic habitat quality index (BHQ) ........................ 192

4.3.10 Denisenko Index................................................... 194

Chapter 5. Analyses of the ecological systems by geoecological evolving organized index................................. 195 5.1 Analysis of the biopolymers .............................................. 195

5.2 Analysis of environmental status of wood and shrub vegetation by the Armenian index of Environmental quality 202

5.3 Assessment of the maturity of oil and natural gas pools by means of the Entropy Index ................................... 210 5.4 Surface water pollution by vanadium ................................. 218

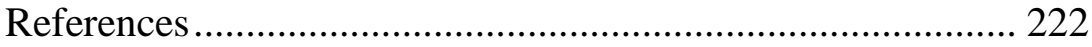




\section{Introduction}

This monograph concludes twenty-years study in the field of hydrochemistry, environmental chemistry and geoecology. It is dedicated to the creation of models of comprehensively assessing and predicting the quality of fresh water. New models are proposed for the integral assessment of the quality and ecological state of freshwater. The created models make it possible to thoroughly study, evaluate and classify the actual ecological state of fresh water objects, clearly assess the damage caused to anthropogenic impacts and its consequences, as well as predict changes in water quality.

The introduction of such models provides a scientific basis for the effective management and efficient use of water resources.

A large scientific school of hydrochemistry and ecological chemistry has been created in Armenia. This scientific school is well known and respected far beyond the borders of Armenia, in the countries of Europe and Asia.

Due to the continuous growth of anthropogenic impact on natural waters and the reduction of freshwater resources in the world, it is necessary to create simple, clear and practical methods for describing and explaining the ecological state of natural waters, as well as predicting possible changes in water quality.

This study results were published in more than 100 articles in scientific journals of Armenia and abroad, presented at more than 30 international conferences and symposia. The developed 
indices are applied to all rivers, lakes, artificial reservoirs, as well as to the groundwater of the Republic of Armenia.

In recent years, the authors have applied the indices developed by them to determine the quality of various bio- and eco-systems. Satisfactory results have been obtained, which have already been implemented at the Kazakh Agrotechnical University to study the state of green spaces in an urban area in order to determine the permanent negative impact of increased gas pollution and air pollution, adverse chemical and physical properties of the soil, asphalt cut, the presence of underground utilities and structures in the root zone of green plantings, etc.

The developed indices were also introduced in the city of Zheleznogorsk at the enterprise of the company "Cosmic Technology" to assess the maturity of naphthid systems (natural gas, oil, associated gas). An oil detection method is also presented, regardless of the depth of the deposits, based on hydrochemical analysis of surface water.

The monograph is published at the suggestion of the Russian Academy of Natural Science and the publishing house "Logos". 


\section{Chapter 1. Natural Water Characterization}

\subsection{Representation about anomalous and specific properties of water}

Water is a chemical combination of oxygen and hydrogen, which is usually denoted by the formula $\mathrm{H}_{2} \mathrm{O}$. It plays a fundamental role in many processes and phenomena occurring in the Earth, on the Earth and around the Earth. All the "secrets" of water have not yet been revealed, although its properties, behavior under various conditions and more are already studied about water. The chemical nature of it is still not fully established, and in fact the water has a more complex composition. The molecular mass of water is 18 , but there are molecules with molecular masses of 19,20, 21 and 22. They consist of heavier hydrogen and oxygen atoms, having an atomic mass of more than 1 and 16, respectively. Natural waters have different isotopic composition. Of the known varieties of water molecules, nine are stable [1-4].

The water molecule has an angular structure: it is an isosceles triangle with an apex angle of $104.5^{\circ}$. The oxygen atom is in the sp3 hybrid state; of the four hybrid oxygen orbitals, two are involved in the formation of single $\mathrm{O}-\mathrm{H}$ bonds, and the other two sp3 hybrid orbitals are occupied by lone electron pairs, their action is the cause of the decrease in the angle from $109.28^{\circ}$ to $104.5^{\circ}$. The water molecule is a dipole containing positive and negative charges at the poles. There is an excess of electron density near the oxygen nucleus, and on 
the opposite side of the molecule about the hydrogen nuclei there is a lack of electron density [2].

It is this structure that determines the polarity of the water molecule. The anomalous properties of water indicate that water molecules are rather tightly interconnected and form a characteristic molecular structure that resists thermal, mechanical and electrical destructive influences. According to modern concepts, the presence of hydrogen bonds between water molecules leads to the emergence of so-called water clusters or complexes. However, the unusual properties of water are associated not only with the presence of a hydrogen bond, but also with the fact that the structure of liquid water exhibits properties as an integral system [3-6].

Below we present the anomalous properties of water [6-9].

1. Heat capacity is the highest, except for $\mathrm{NH}_{3}$ (at $20^{\circ} \mathrm{C}$ $4731 \mathrm{~J} /(\mathrm{kg} \cdot \mathrm{K})$. At atmospheric pressure and temperature up to $100^{\circ} \mathrm{C}$ it is in the form of a liquid and its heat capacity varies from 4174 to $4220 \mathrm{~J} /(\mathrm{kg} \cdot \mathrm{K})$. The dependence of the heat capacity of water on temperature at atmospheric pressure is not linear. When water is heated to $27^{\circ} \mathrm{C}$, the heat capacity decreases from 4217 to $4174 \mathrm{~J} /(\mathrm{kg} \cdot \mathrm{K})$, then in the temperature range $27-40^{\circ} \mathrm{C}$ the value of this quantity remains almost constant (it should be noted that in this temperature range water has the most lower heat capacity.) At temperatures above $40^{\circ} \mathrm{C}$, its specific heat capacity increases and reaches its maximum at a boiling point of $4220 \mathrm{~J} /(\mathrm{kg} \cdot \mathrm{K})$.

With increasing pressure, the specific heat capacity of water decreases, but the boiling point of water also increases, for example, at a pressure of 100 bar (atmospheres), it is in a liquid 
state even at a temperature of $300^{\circ} \mathrm{C}$. The specific heat capacity of water in this case amounts to $5700 \mathrm{~J} /(\mathrm{kg} \cdot \mathrm{K})$. With continued heating of water, for example, up to $320^{\circ} \mathrm{C}$, it turns into steam, which has a large heat capacity. However, at low pressures, water begins to boil and turns into steam at temperatures well below $100^{\circ} \mathrm{C}$. For example, according to the table, at a pressure of $0.1 \mathrm{bar}$ and a temperature of $50^{\circ} \mathrm{C}$, water is already in the form of water vapor, and its heat capacity under these conditions is equal to $1929 \mathrm{~J} /(\mathrm{kg} \cdot \mathrm{K})$. As shown, in the temperature range of the human body of $30-40^{\circ} \mathrm{C}$, the heat capacity of water is minimal. This remarkable property of water determines the equal probability of the flow of reversible and irreversible biochemical reactions in the human body and provides entropy information management of them.

2. Boiling point and freezing water. If water were a normal monomolecular compound, such as, for example, the hydrides of its analogues: sulfur, selenium, and telur in the sixth group of the periodic system of elements D.I. Mendeleev, then in the liquid state the water would exist in the range from minus $100^{\circ} \mathrm{C}$ to minus $80^{\circ} \mathrm{C}$ (Table 1.1).

Table 1.1

Boiling and freezing points for water and its chemical analogues.

\begin{tabular}{|c|c|c|c|c|}
\hline \multirow{2}{*}{ Parameters } & \multicolumn{4}{|c|}{ Substances } \\
\cline { 2 - 5 } & $\mathbf{H}_{\mathbf{2}} \mathbf{O}$ & $\mathbf{H}_{\mathbf{2}} \mathbf{S}$ & $\mathbf{H}_{\mathbf{2}} \mathbf{S e}$ & $\mathbf{H}_{\mathbf{2}} \mathbf{T e}$ \\
\hline $\mathrm{M}, \mathrm{g} / \mathrm{mol}$ & 18 & 34 & 80 & 129 \\
\hline$<\mathrm{HRH}$ & 104,6 & 92 & 90 & 90 \\
\hline $\mathrm{T}_{\text {boil., }}{ }^{\circ} \mathrm{C}$ & 0 & -82 & -64 & -51 \\
\hline $\mathrm{T}_{\text {freez., }}{ }^{\circ} \mathrm{C}$ & 100 & -61 & -42 & -4 \\
\hline
\end{tabular}


3. Water volatility is the smallest, whereas for hydrogen compounds with elements of the oxygen subgroup, it increases during the transition from Telur to sulfur (Table 1).

4. Depending on temperature, the density of water is maximum at a temperature of 3.8 to $4.2^{\circ} \mathrm{C}$. Under these conditions, the exact value of the density of water is 999.972 $\mathrm{kg} / \mathrm{m}^{3}$. Such a temperature dependence of the density is characteristic only for water. Water exists as a separate liquid at a temperature of from 0 to $374.12^{\circ} \mathrm{C}$ - this is its critical temperature at which the interface between the liquid and the water vapor disappears. Other common liquids do not have a maximum density on this curve - their density decreases evenly as the temperature rises. Thus, for the entire biosphere, an extremely important feature of water is its ability to increase and not decrease its volume during freezing, i.e. reduce the density. When freezing the water expands, so the ice remains to float on the surface of the freezing reservoir. The temperature of the freezing water under ice is $0^{\circ} \mathrm{C}$. In the more dense layers of water at the bottom of the reservoir, the temperature is about $4^{\circ} \mathrm{C}$. Due to this, life can exist in the water of freezing reservoirs.

5. Compressibility, that is, the degree of volume reduction with increasing pressure. Typically, the compressibility of a liquid increases with temperature: at high temperatures, liquids are looser (less dense) and easier to compress. When water is heated from the melting point down to $46^{\circ} \mathrm{C}$, the compressibility decreases and then increases.

6. The specific heat of ice melting is the highest (330 $\mathrm{kJ} / \mathrm{kg}$ ), with the exception of $\mathrm{NH}_{3}-332.3 \mathrm{~kJ} / \mathrm{kg}$. 
7. The specific heat of evaporation is the highest of all substances. At normal atmospheric pressure, the specific heat of water vaporization is $2258 \mathrm{~kJ} / \mathrm{kg}$, and the boiling point of water is $100^{\circ} \mathrm{C}$. With increasing pressure, for example, to $100 \mathrm{~atm}$., The heat of water vaporization decreases to $1315 \mathrm{~kJ} / \mathrm{kg}$. The temperature of water boiling varies depending on pressure as follows: as pressure increases, water boiling temperature increases and reaches a maximum value of $374.15^{\circ}$ in critical state $\mathrm{C}$ at a pressure of 218.4 atmospheres. High specific heat of evaporation is extremely important for the transfer of heat and water in the atmosphere.

8. Thermal expansion - the temperature corresponding to the maximum density decreases with increasing salinity. The coefficient $\beta$ is called the temperature coefficient of volume expansion. This coefficient for liquids is tens of times greater than that of solids. In water, for example, at a temperature of $20^{\circ} \mathrm{C} \beta \mathrm{B} \approx 2 \cdot 10-4 \mathrm{~K}-1$. Thermal expansion of water has an anomaly that is interesting and important for life on Earth. At temperatures below $4^{\circ} \mathrm{C}$, water expands as the temperature decreases $(\beta<0)$. The maximum density is $\rho$ в $=103 \mathrm{~kg} / \mathrm{m}^{3}$ water has at a temperature of $4^{\circ} \mathrm{C}$.

9. Surface tension is the highest of all fluids except mercury. At water, the surface tension coefficient at a temperature of $20^{\circ} \mathrm{C}$ in air is $72.86 \mathrm{mN} / \mathrm{m}$. For mercury, $20^{\circ} \mathrm{C}$ in air is $486.5 \mathrm{mN} / \mathrm{m}$. High surface tension allows water to have a spherical shape with a free fall. Surface tension and wetting are the basis of the special properties of water and aqueous solutions, called capillarity. Capillarity is of paramount importance for the life of the plant and animal world, the 
formation of the structures of natural minerals and the fertility of the earth. In microchannels, water acquires amazing properties. It becomes more viscous, compressed by one and a half times, and freezes at $-75^{\circ} \mathrm{C}$. Bound by intermolecular forces with the surface of pores and microcavities of rocks and minerals of the earth's crust and other objects of animate and inanimate nature. This pore water has a special structure.

10. The relative dielectric constant is the highest among all liquids (for pure water $\varepsilon=81$ at $20^{\circ} \mathrm{C}$ ), with the exception of formamide $\left(\varepsilon=84\right.$ at $\left.20^{\circ} \mathrm{C}\right)$. The large value of the dielectric constant is due to the peculiarities of the molecule $\mathrm{H}_{2} \mathrm{O}$. This is due to the fact that water is a highly polar liquid and therefore has a soft orientational degree of freedom (that is, rotation of molecular dipoles). Each water molecule has a significant dipole moment. In the absence of an electric field, the dipoles are randomly oriented, and the total electric field created by them is zero. If water is placed in an electric field, then the dipoles will begin to reorient so as to weaken the applied field. This pattern is also observed in any other polar liquid, but water, due to the large value of the dipole moment of $\mathrm{H}_{2} \mathrm{O}$ molecules, is able to weaken the external field very strongly (80 times).

11. Solubility - as a rule, dissolves most substances. Experiments have shown that, after heating at high temperatures and pressures, water and water solutions are in a metastable state for some time after heating. Metastable water is characterized by increased dissolving ability with respect to carbonates, sulphates, oxides and silica; it has low $\mathrm{pH}$ values and keeps abnormal amounts of dissolved substance in its composition for a long time. Thus, water activated at 200,300 , and $400^{\circ} \mathrm{C}$ 
increases its dissolving capacity with respect to calcite by 2, 3, and 4 times, respectively [7-9]. The ability of water to maintain its structural state for some time after changing external conditions is called the structural memory of water [9].

12. Electrolytic dissociation is very small. Water is a neutral substance, although it contains $\mathrm{H}^{+}$and $\mathrm{OH}^{-}$ions.

13. Thermal conductivity - the highest of all liquids. At $35^{\circ} \mathrm{C}$ water has the lowest thermal conductivity. Plays the main role in the processes that occur in living cells, but for molecular processes it turns out to be much more important than the vortex conduction

14. Viscosity - at temperatures below $35^{\circ} \mathrm{C}$ with increasing pressure from atmospheric to $0.2 \mathrm{GPa}$, the viscosity of water decreases, passes through a minimum and only then increases. It determines the hydrodynamics of water bodies and sedimentation of suspended substances.

15. Transparency is relatively great. Strongly absorbs the radiant energy of the sun in the infrared and ultraviolet regions of the spectrum; relatively small electoral absorption is observed in the visible region of the spectrum, so water is colorless: absorption features are important for physical, chemical, and biological processes.

16. The speed of sound in water. For all liquids except water, the speed of sound decreases with increasing temperature. The dependence of the speed of sound in water on temperature at atmospheric pressure is not linear. When water is heated from 0 to $70^{\circ} \mathrm{C}$, the speed of sound in water increases from 1403 to $1555 \mathrm{~m} / \mathrm{s}$, then in the temperature range of $70-85^{\circ} \mathrm{C}$, the value of this value remains almost constant. At a temperature above 
$85^{\circ} \mathrm{C}$, the speed of sound in water decreases and boiling point reaches $1543 \mathrm{~m} / \mathrm{s}$.

\subsection{Assessment of Natural Water Quality}

\subsubsection{Surface water}

The greatest anthropogenic effect is currently under the influence of surface freshwater, and their protection against pollution is one of the most important issues worldwide. This is particularly relevant in the case of a transboundary river, where this problem can only be solved by the joint efforts of different states.

Surface water quality is a set of physical, chemical, and biological indicators, which determine the water availability for this or that water use industry. It is characterized by the content and quantity of substances in the water soluble or suspended in water, with the content of microorganisms and biomass, by temperature and by a number of other physical characteristics. A large amount of freshwater is used to meet the needs of the population, the majority of which reaches a natural water body due to the water circulation (with precipitation, surface flow, partially treated or treated without wastewater). Freshwater ecosystems are also in direct dependence on the state of the catchment basin, the level of its anthropogenic impact (buffering).

The buffering of water ecosystems (buffer level, ecological level, ecological reserve) is manifested as the ability of these natural formations, which, due to internal chemical, biological and physical processes, neutralizes or substantially reduces the 
negative effects of natural factors and anthropogenic load. Buffering imposes a limitation on the aquatic ecosystems [1012].

In many cases, changes in hydrochemical regimes caused by anthropogenic factors, first of all, chemical pollution, are aimed at humanitarian adverse effects - reduction of biological self-cleaning intensity. The sources of chemical pollution of natural waters are domestic, industrial wastewater, surface water flow from industrial plants and dwellings, agricultural and minefield and mineral wastewater.

Although household wastewater are subjected to certain pre-treatment sludge (other types of purification in the republic), they contain a large number of organic and mineral substances in a solvent or contaminated state. This type of wastewater is formed in residential and public buildings, in the premises of food, sanitation, after washing, and so on.

According to the literature data, the following amount of pollutants is dispatched from one person per day: $-65 \mathrm{~g}$ depending on the drainage system; organic substances (by BOD) in colorless liquid $-70 \mathrm{~g}$, colored $-40 \mathrm{~g}$, ammonium nitrogen -8 $\mathrm{g}$, phosphates (by anhydride) $3.3 \mathrm{~g}$, detergents $-1.6 \mathrm{~g}$, chlorides $9 \mathrm{~g}$, surface active substances $-2.5 \mathrm{~g}$.

Industrial wastewater (even from cellulose-paper, chemical, metallurgical and other industries), even they corresponds to good water quality that are officially allowed to shed rivers are commonly contaminated with powder, oil, mineral salts, heavy metals and are often dumped in hot form is the thermal pollution of natural waters. These streams are characterized by the high 
content of contaminants and ingredients, due to the type of production, water supply and drainage systems.

In industrial factories, $90 \%$ of water is consumed in the process of production mainly for the freezing of products or equipment, so that the waste water is only thermally polluted (1st grade wastewater). In this case, the emergency mode and leakage are ignored. In the 2 nd industrial waste water, water serves as an absorber and dissolved dispersing mixtures, partially soluble salts, which are polluted. 3rd grade waters are similar to the 2nd order, but they are pre-heated due to contact with the product. The 4 th grade industrial waste water is a direct reaction component and is contaminated by all the components of the process.

Surface flow is formed from rain, melting and dripping streams. The factors contributing to this flow are:

1) Intensity and continuity of atmospheric precipitation;

2) the total area of the settlement and its structural features;

3) location relay.

The concentration of pollutants in the surface flow varies widely and depends on the production direction of the plant. Mainly overcrowded (130-113 mg/L), organic matter, petroleum products, biological elements, heavy metals (mostly $\mathrm{Ni}, \mathrm{Cr}, \mathrm{Zn}$, $\mathrm{Pb})$ are revealed.

Depending on the high content of particles (often rich in heavy metals), they are characteristic of metallurgical factories, ore-dressing factories, and construction industry. The maximum content of organic pollutants is seen in food and light industry fluids. In some cases (leather factories, slaughterhouses, mecombinates), it is also possible to inflate surface flow through 
microfluenza, and the garbage of the road sections has a large amount of organism, biological elements, heavy metals.

Flows form agriculture is separated from animal breeding complexes, surface flow streams, drainage waters. The introduction of new production methods in the economy and the large concentration of livestock in smaller districts have made livestock breeding a major source of pollution of water objects. The amount of wastewater generated in livestock complexes and farms is quite large, and sometimes exceeds the amount of household wastewater. The main pollutants in this wastewater are organic materials, nitrogen, phosphorus, soluble materials, which comprise $20-35 \%$ of the total volume and the percentage of $65-80 \%$.

Outflow feeds from open feeding areas also have a significant impact on surface water pollution. The flow volumes depend on the rainfall intensity, the location relief, and the animal density. Flow coefficient of condensed livestock may reach up to 0.9-0.95.

In the composition of the surface springs, gullies and mudflows of agricultural spoons are substances that are used for soil fertilization and plant protection (nitrogen, phosphorus, potassium, pesticides). The possible removal of viable elements depends on many factors (from the quantity given, the chemical composition of the fertilizer, surface flow, soil type) and varies widely.

Long-term use of fertilizers penetrates surface and groundwater into $20 \%$ of imported nitrogen and $1.5-2 \%$ of phosphorus. The withdrawal of pesticides depends on the size of the feedstock, the rate of decay, the ability to migrate, the 
intensity of the water flow, the period between the release of pesticides and precipitation.

During land irrigation, washable surfaces and easily flowable solutes, primarily sodium, sulphates and chlorides pass through the surface. Mineralization of sludge-coated waters varies within the range of 1-15 g/l, mostly chloride-sulphatesodium. As a result of the inflow of these water bodies, water mineralization is rising primarily due to $\mathrm{Na}^{+}, \mathrm{SO}_{4}^{-2}, \mathrm{Cl}^{-}$ions, and the composition changes from hydrocarbonicalcium to chloridesulphate-sodium.

\subsubsection{Groundwater}

The natural factors that make up the composition of groundwater are mainly physico-geographical, geographical, hydro geographical, biogeographical factors. One of the most important things in the development of groundwater is climate. Annual atmospheric precipitation impacts not only on the chemical composition of groundwater, but also the deeper layers of water. In winter, the changes in hydrochemical content and increase in mineralization of the groundwater are revealed, due to lack of feeding the water table by atmospheric precipitation. Combination of groundwater level and chemical composition modes with the nature of atmospheric precipitation has shown that winter precipitation is more efficient, as the level of groundwater drainage in spring increases, and groundwater diminishes.

Combination of groundwater level and hydrochemical regime with the type of atmospheric precipitation is shown that 
the infiltration of the melting water into groundwater is more efficient in winter than in spring, when the groundwater table increases and the water mineralization decreases. The climate determines not only the addition of the water table at the expense of atmospheric precipitations, but also the intensities of the mountain rock rush. Thus, the basis of the Earthquake genetic classification lies in the landscape climatic factor, which determines the type of water regime, the average annual precipitation, and the air temperature. The participant of the Earthquake reaction is water, during which movement of reagents and removal of chemical reactions. The speed of water movement in the aeration and saturation belts determines the composition and density of soluble components in the water and the chemical changes of rock during their winding. Therefore, the intensity of waterlogging is an important factor for the chemical content of groundwater and wind gases of mountain rocks.

The impact of the hydrological factor on groundwater depends on the specifications of the hydrological network. The presence of a thick and deep-seated network contributes to the infiltration of groundwater and pressure water conduits. During the floods, rivers water fills the groundwater table in the coastal zone, reducing their mining and altering the composition. Underground and surface waters represent one hydraulically coupled system and the balance of some of the components affects the state of the other part.

Geological structure, location, origin, mineral composition and organic matter of rocks have a great impact on the formation of the composition of groundwater. One of the most important 
factors in the formation of water content is the dynamic order of aquifer horizons and their interaction and contact with surface water. The impact of the biological factors on hydrochemical content of groundawater through bacteria is appeared with transforming the organic substances. Organic substances in this or that quantity are available in all types of sedimentary rocks. Most of the organic materials are in the upper layer and this is due to vegetation. Organic acids accelerate the decay process. Biological carbon dioxide produced by oxidation of organic matter is dissolved in groundwater and reacts with rock minerals and is considered an aggressive agent for their solving.

The composition of ground water content depends on the properties of chemical elements and their compounds. Assessment of migratory forms of elements is important for studying the balance of groundwater and mountainous rocks.

The formation of groundwater content is closely related to the removal of mountainous rock and the removal of soluble components. The effects of the above factors are not stable. They are characterized by the dynamics of changing time and space, conditioned by the geo-geographical situation and the history of geological development.

Anthropogenic factors of the formation of groundwater content. The anthropogenic impact on the natural environment is related to the history of human society development. The vegetation was the first in nature to have human impact when the forests were demolished during the formation of agriculture. Atmospheric changes - climate warming and air pollution became increasingly common. Violations of certain factors of nature have regional or local nature. 
The hydrographic network in many areas has been transformed into reservoirs, water pipelines, and pipelines. Part of rivers, lakes, marshes and other relief deserts are used for emissions and accumulation of water. Artificial networks of surface water transport are created for the development of agriculture in scarce wetlands. During the irrigation season, the conditions of groundwater nourishment and drainage essentially change, and radical change in their composition occurs. The change in the hydrographic network is a violation of the natural flow of surface water. In riverside valleys, surface water flows through the underground stream, leading to changes in the composition of groundwater.

The relief changes in construction, agricultural works and mining operations have an indirect impact on the composition of groundwater. Relief of the relief decreases the land surface slopes, which leads to the violation of the natural surface formation conditions and promotes increase in atmospheric precipitation and groundwater infiltration. There is a significant increase in solid waste in the regions of mining and processing plants and the growth of solved quantities due to the peculiarities of man-made impacts. Violations of the natural process of solids and soluble substances transfer can dramatically change the natural conditions. Especially this refers to the release of liquid and solvents, which can lead to largescale pollution of the natural environment.

Violation of the conditions of groundwater formation may be filtered from reservoirs without an anti-filtration system and the waters penetrated by irrigation networks. Irrigation waters, as well as excessive wastewater and washing waters penetrate 
into the groundwater aquifer from agricultural land. Irrigation waters contain soluble salts whose composition and quantity depend on the source of irrigation water. The penetration of soluble compounds from a wide range of groundwater antibacterial activity is carried out by groundwater horizons through surface infiltration waters of natural or artificial origin and is often accompanied by changes in the composition of ground and intermountain water. Atmospheric, surface, groundwater and pressure water are associated with close contact and high dynamics of contamination of groundwater pollution.

Water is considered to be contaminated if the composition and condition of the human activity are directly or indirectly altered and become unusable. Currently, the main sources of pollution of surface and groundwater are unclear or incomplete industrial and utility-household waste water. The technician's intensification is accompanied by the increase in the volumes of waste water and the violation of the natural conditions of the groundwater protection from pollution. The polluted area of groundwater is maintained for a long time, even after the pollution source is destroyed. Thus, according to US hydrologists, the groundwater water supply is approximately 150 times slower than surface water scrubbing, and therefore if pollution occurs, decades will be needed for the recovery of consequences. Changes in hydrogeological conditions are directly or indirectly influenced by engineer activity. Underground waters are directly impacted by their exploitation, the creation of infiltration intakes, the lowering of the level in the exploitation of mines or the burial of industrial waste in 
underground construction, their depletion during the operation of existing oilfields, water infiltration from reservoirs and irrigation systems, etc.

Indirect effects are also varied. The most significant change in the conditions of groundwater formation is occurring in the construction sites and is determined by the surface water thermal equilibrium violations associated with the infiltration of irrigation water outflows from asphalting, sewerage, water mains and heating networks. All of these factors lead to a permanent breach of the water balance, as a result of additional groundwater extinction. It is accompanied by increase of groundwater level and development of waterlogging of territories. All these factors lead to changes in groundwater level, temperature and chemical regimes, and can lead to their qualitative and quantitative exhaustion [13].

\subsection{Study of the hydrochemical regime of natural water in the Republic of Armenia}

In Armenia, different types of hydrochemical monitoring of natural water are carried out since 1964. Hydrological surveys, minerals exploration, search of water supply sources for towns, rural areas and individual enterprises were conducted over time.

The study of the chemical composition of groundwater in the Republic of Armenia has a history of about a century. Geological prospecting services were carried out for the assessment of freshwater underground water resources to be exploited, inventory of well-watered horizons and systems suitable for use. Regime observations have begun since 1949, 
and since 1966, a permanent hydrogeological observation network has been established, covering about 1,000 groundwater sources. In 60 of the water reservoirs, hydrological and hydrochemical regime investigations were carried out. Hydrogeological maps of the Regions were based on groundwater conditions. Since 1980, the assessment of the natural protection of water sources from pollution and pollution has begun [14-24].

The drinking-household water supply sources were exploited for at least 3 years before exploitation. The study program included data on the general geological structure of the area, the water-intake basin, water-soluble rocks. The potential impact of the nutritional zone on water quality was taken into account, and the sanitary condition of the immediate vicinity of the well was investigated.

The further monitoring was carried out by organizations operating underground resources at least four times a year during the first year, following the results of the first year, in the most unfavorable period, but at least once a year. Perennial data contains data on organoleptic, dry sludge, total rigidity, hydrogen peroxide, permanganate oxidation, chlorides, sulphates, iron, magnesium, copper, zinc, nitrates, nitrates, ammonium ions, and fluorine content. Drinking and water supply sources of towns and villages in the Republic were subject to systematic observations. Water quality of the water bodies was regularly monitored by sanitary-epidemiological services.

The studies on groundwaters are mainly devoted to regional hydrogeology issues, such as the discovery of the relationship between the formation of groundwater chemical composition 
and the geological structure of the area, the composition of rocks and the nature of the physico-geographical factors. Underground waters were explored for a wide variety of application issues such as hydraulic engineering, manufacturing and other design, data bank creation, and sanitary-epidemiological surveillance.

The estimate of water discharges and pollution was carried out in the short 80s of the last century. The results of perennial hydrochemical observations were not summarized, the groundwater monitoring did not include the prediction of changes in water content, the impact of natural and anthropogenic factors. The studies did not take into account the consequences of long-term exploitation of water supply sources.

The characteristic of the most generalized groundwater is presented in the regional geoanalysis of Armenia. It is shown that the regional system has tremendous horizontal and vertical zones of tectonic and morphological view. The free-lane waterbelt zone includes the ground and groundwater flow, as well as all artesian basins. Most of the country's underground waters are part of this group. Difficult water-exchange zones are the waters of the lithological horizons of corrugated sediments, which are not of practical interest, in the structural slopes of the pre-poles. According to the chemical composition of the groundwater belongs to the following main types [13]:

1. Hydrocarbonate-sodium type, which is owned by most of the country's groundwater.

2. Sulphate-sodium type, which is attributed to gypsumsaline sediments, as well as to some sulphide mines. 
3. Chlorine-potassium type, which has a limited distribution and is attributed to regions with dysfunctional disorders that shift the pre-pollen corrugated structures.

4. Chlorine-magnesium type, which is attributed to the distribution areas of oligocene-benzene saline.

The chemical composition of ground freshwater in Armenia belongs to hydrocarbonate-calcium waters, in which several types of water-bearing horizon rocks are distinguished. Hydrocarbonate-chloride-sulphate-calcium-sodium waters dominate in the waters of the Andesitophosphate. Hydrocarbonate-chloridecalcium-sodium waters dominate in the waters attributed to older volcanic rocks. Hydro-carbonate-calcium-magnesiumsodium waters are found in the sedimentary rock, especially in carbonate rock waters $[13,21]$. 


\section{Chapter 2. Assessment of natural water quality}

One of the most important issues for water resources monitoring is their proper assessment and classification of pollution levels for which systematic, systematic and long-term studies of water content are required. The accurate water quality data allow for the rational use of water resources, improving the ecological state of the aquatic ecosystem and adjacent areas, reducing the anthropogenic impact and so on.

In general, two kinds of approaches are mostly used for water quality assessment: physico-chemical and biological. In a case of the physicochemical method the "point" assessment of water quality, determination of the nature and type of water pollution, and define the hazardous effects of pollutants are carried out. The main advantage of this method is that the results of the water analysis obtained through it are distinguished by high precision, give qualitative and quantitative data, which allows them to use water quality standards according to accepted standards. The biological method allows only the assessment of general impact of pollutants on water ecosystems, as well as determination of the size of the breaches in the ecosystem and allow for an integrated water quality assessment.

As a control indicator for the physicochemical assessment of surface water quality, the concept of the maximum allowable concentration (MAC) is considered [14-16, 22-23]. 


\subsection{Assessment of water quality through the water quality norms}

In order to prevent the negative impacts of pollutants on separate components of the environment, it is important to know their permissible limits, in which the normal functioning of organisms is possible. The main dimension of ecological norms for the content of harmful chemical compounds in the natural environment is the maximum allowable concentration. MAC is a concentration of the harmful substance in the environment, which does not affect human health and does not result in adverse effects for future generations in the case of continuous import or exposure to a certain period of time. When determining the MAC, not only the effects of pollutants on human health but also their effects on animals, vegetation, micro-organisms, as well as on ecosystems are taken into account.

In order to establish the MAC, it is become possible by two: by diluting the chemical in the water object or by emission control. In the first case, no improvement in production technology and construction of expensive cleaning equipment is required. Wastewater is immediately expelled from natural water bodies by artificially diluting the content of chemicals contained therein. However, the current ecological state of the environment requires full refusal from similar "preservation" methods of the biological environment of chemical pollutants and the transition to natural environment emission limitations and, in the future, to their full ban on some water objects. 
Surface water quality is normalized for economic, drinking, cultural and household water use. In the first two categories, the sanitary and hygienic norms are decisive. MACs for harmful substances are established for 521 pollutants in reservoirs and freshwaters. This number is grouped into the following hazardous limiting indicators: toxicological, organoleptic, fishery and general sanitary.

It should be noted that assessment of natural water quality through MAC do not give a complete picture of the state of natural water and are not a sufficient safeguard against contamination.

The above rules based on the concept of the achievement of good water quality of the rivers and open water bodies for the drinking, household and fish breeding use. This approach has already led to the fact that many rivers in the country are polluted locally or in a continuous flow through the whole stream. Self-cleaning processes in leaky and leaky reservoirs are progressing more slowly and often occur in emergency situations.

Modern water purification systems are built to perform destructive methods which mean the destruction of water pollutants by oxidation, rehabilitation, hydrolysis, and other ways in which decomposition products are removed from the water in the form of gases or sediments. As a result, non-toxic mineral salts penetrate the natural water system in the same quantities as the MACs, but many times exceed their natural concentrations in the aquatic environment. That is why rivers and reservoirs that polluted waste that have been thoroughly cleaned from organic compounds of nitrogen, phosphorus, 
sulfur, and other elements, however, increase the content of soluble sulphates, nitrates, phosphates and other mineral salts that in turn cause eutrophication processes bring to their "flowering" due to the rapid growth of bacterial algae.

The modern industry uses an annual amount of synthesis and uses a large number of new chemical compounds, which are inevitably delayed by the fact that penetration into natural water can cause these compounds to combine new, unexplored compounds with still unclear properties. Thus, the existing MACs cannot fully reflect the influence of foreign materials on the aquatic ecosystem and correctly assess the ecological state of the water object. New alternative methods of surface water quality assessment should be sought.

While MACs are used for the assessment of natural water quality, as a water quality norm is also applied the background concentration of hydrochemical parameters in the given water body. The assessment of the quality of natural water based on the background concentrations of hydrochemical indicators gives a more accurate picture of the ecological state of the water object, taking into account the natural content of the given hydrochemical indicator. Often, when evaluating the quality of the natural water quality, MACs are misleading results because the content of this or that hydrochemical index in the aquatic environment is higher (endemic origin) than that of the accepted MAC.

In this case, the water object cannot be considered polluted, but it is the long-term hydrochemical peculiarity of the given water object, proceeding from the geochemical characteristics of the site. For example, in a number of large rivers in Armenia, 
such as Hrazdan, Metsamor, Debed, Aghstev, Akhuryan, Voghji, Vorotan, the copper and vanadium exceed the MAC $(0.001 \mathrm{mg} / \mathrm{l}) 2-5$ times, but have a natural origin and is not a characteristic of pollution.

Based on these considerations, it is best expedient to replace the MACs with the background concentration of the hydrochloric acid in the river water during the evaluation of the natural water quality. In such a case, water quality norms are verified by a reference point (source of rivers) where there is no anthropogenic impact on the results of non-parametric statistical analysis of the results of the last five years of hydrochloric acid in the water. This approach has been based on the ecological norms of water quality in a number of rivers in Armenia.

Priority was given to the list of "primary" substances for the determination of the chemical status of the water object and the 5-point scale of the ecological status classification. As part of the class as a first class, excellent ecological status, the concentrations of hydrochemical indicators in the river water reference point are taken, and for the other classes, the doublelayer concentrations of hydrochemical indicators are given twice, and then quadrupled and eight [14-16, 22-36].

\subsection{New approaches for integrated assessment of natural water quality}

Controlling the regularity of chemical processes in the water environment allows developing water quality prediction methods, justifying the requirements for wastewater and 
drainage water purification, directing the impacts on the water environment self-cleaning and detoxification processes.

Solving the problems of rational utilization and management of water resources in the region provides for information on the current state of the quality of water resources, which will be aimed at further predictability of ecological burden. This focuses on the functioning of monitoring systems, taking into account the natural water selfpurification ability.

One of the interesting features of ecosystems is their ability to self- purification which called also ecological capacity. At the expense of internal chemistry and physical processes, ecosystems have significant mitigation of the adverse effects of anthrax and natural factors. This capability has limits that lead to structural and functional reconstruction of systems, and then to degradation and death. This refers to water ecosystems that are regularly polluted not only by a significant amount of chemicals, but also by expanding the list of pollutants. As a result, this water object becomes unfit for water use.

In recent years, new methods of water quality assessment have been developed to prevent natural gas consumption and intensive pollution. In 2000, EU Member States developed and entered into force with the Directive 2000/60/EC of the European Union (Water Framework Directive) aimed at the protection and improvement of natural water quality. The purpose of the Water Framework Directive (WFD) is to evaluate and classify the natural waters according to the ecological status, identify the risk areas of the water object, due to the human water and natural high levels of pressure and to take measures to 
restore the good status of the water object. According to the WFD, ecological status and chemical status concepts are defined for the quality of natural waters, which define the classification systems for water biological, hydromorphological and physicochemical quality indicators.

The ecological status of the water object is determined by the biological and hydromorphological indices according to which the water object is classified into 5 statuses [37-41]:

1. Excellent status when anthropogenic effects on the water body are insignificant or absent,

2. Good status when there is a slight change in the water object compared to its natural state,

3. Moderate status, when there are moderate changes compared to the natural state (many sensitive species disappear, but the ecosystem functions are largely preserved);

4. Poor status when biological coexistence varies greatly compared to nature (dominant dominant species, sensitive species are very rare, and the functions of the ecosystem have changed).

5. Bad status when biological coexistence has undergone significant changes compared to natural.

These 5 ecological statuses are determined by four basic biological indicators: phytoplankton, macrophytes, macroinvertebrates and fish. The ecological status of the water object's biological indexes is determined by the extent of the deviation from the value of this indicator in the absence or insignificance of anthropogenic (reference or pure state) value. 
Despite the theoretically clear argument, the definition of the ecological state of the water object is actually complicated and time-consuming process, which requires the development of the geological features of the region, the measurement of biological indicators and the identification of the reference state, the determination of the typology of the water object, and so on. Furthermore, the assessment of the ecological status by the biological indicators of the water object should be substantiated by appropriate hydromorphological and physicochemical indicators. The chemical status of the water object is determined by the concentrations of the hydrochemical indices, classifying it as "good chemical status" or "bad chemical status." The classification is made according to the list of 41 priority substances identified by the WFD, which includes the most commonly used substances for aquatic organisms. These substances have been adopted for environmental quality standards (EQS), the lower concentrations of which correspond to the "good chemical status". According to WFD requirements, in case of "bad chemical status" the concentrations of substances exceeding EQS should be reduced, and in the case of more toxic compounds, they will be completely eliminated.

Thus, according to WFD, the water body's water is considered to be of high quality when it is ecologically and chemically qualified for excellent / good quality [37]. 


\subsection{Antropogenic Impact on water quality of natural water resources}

As a result of rapid development of agriculture and industry, human activity has a great impact on water resources. These effects can be both quantitative and qualitative. Quantitative impacts are mainly due to the non-compliance of the river flow ecological flow due to large volumes of water, for hydropower, industrial or other purposes. Qualitative impacts on water objects are largely due to the entry of water objects into different types and quantities of pollutants [42-44].

Under continuous anhydrous effects, water objects are polluted not only by significant quantities of pollutants, but also increases their list.

In recent years, natural water systems have penetrated such synthetic chemical compounds that have never been synthesized by nature. The latter are subjected to extremely slow degradation in nature and can accumulate and retain water bodies (river, lake, reservoir, sea, etc.) for a long time. Therefore, in order to undertake appropriate measures to reduce or eliminate anthropogenic impacts on water objects, it is necessary to identify the extent and nature of anthropogenic impact on the water body.

In Armenia, surface waters, in particular, rivers, are polluted mainly by utility-household wastewater settlements, household solid waste, backward flows from agriculture, mining wastewater, surface waters formed by precipitation in open mines and tailings dumps. In recent years, the tourism 
development in the region also has a significant impact on the quality of river water in the country [23].

Hydrochemical monitoring data for 2007-2014 were analyzed for the preliminary assessment of the impact of different economic sectors on the water quality of rivers in Armenia [23].

The long-term surface water quality monitoring was carried out by the Environment Impact Monitoring Center of the Ministry of Nature Protection of the RA. The analysis of the monitoring data was carried out in accordance with the norms approved by the Government Decree \# 75-N [37], based on the background concentrations of hydrochemical indicators in the reference point for the given river or river basin. According to these standards, the quality of the evaluation rivers is classified as 5 classes, excellent (I), good (II), medium (III), insufficient (IV) and poor (V) (Table 2.1).

Table 2.1.

Water quality class, hydrochemical parameters and pressure-impact analysis of the rivers in Armenia in 2007-2014.

\begin{tabular}{|c|c|c|l|l|}
\hline \multirow{2}{*}{$\begin{array}{c}\text { Observation } \\
\text { point }\end{array}$} & $\begin{array}{c}\text { Water } \\
\text { quality } \\
\text { class }\end{array}$ & $\begin{array}{c}\text { Hydrochemical } \\
\text { parameters } \\
\text { specified the } \\
\text { water quality } \\
\text { class }\end{array}$ & $\begin{array}{c}\text { Main factor } \\
\text { pressure- } \\
\text { impact on } \\
\text { water quality }\end{array}$ \\
\hline \multirow{2}{*}{$\begin{array}{c}0.5 \mathrm{~km} \text { upstream } \\
\text { Hartagyugh } \\
\text { village }\end{array}$} & (II) good & All indicators & None \\
\cline { 2 - 5 } & $\begin{array}{c}0.5 \mathrm{~km} \\
\text { downstream } \\
\text { Spitak town }\end{array}$ & (II) good & All indicators & None \\
है & & \\
\hline
\end{tabular}




\begin{tabular}{|c|c|c|c|c|}
\hline 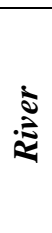 & $\begin{array}{c}\text { Observation } \\
\text { point }\end{array}$ & $\begin{array}{c}\text { Water } \\
\text { quality } \\
\text { class }\end{array}$ & $\begin{array}{c}\text { Hydrochemical } \\
\text { parameters } \\
\text { specified the } \\
\text { water quality } \\
\text { class }\end{array}$ & $\begin{array}{c}\text { Main factor } \\
\text { pressure- } \\
\text { impact on } \\
\text { water quality }\end{array}$ \\
\hline & $\begin{array}{l}0.6 \mathrm{~km} \text { upstream } \\
\text { Vanadzor town }\end{array}$ & (II) good & All indicators & None \\
\hline & $\begin{array}{c}4.5 \mathrm{~km} \\
\text { downstream } \\
\text { Vanadzor town }\end{array}$ & (IV) poor & $\begin{array}{l}\text { Ammonium and } \\
\text { phosphate ions }\end{array}$ & $\begin{array}{l}\text { Domestic } \\
\text { wastewater of } \\
\text { Vanadzor } \\
\text { town }\end{array}$ \\
\hline \multirow{3}{*}{ 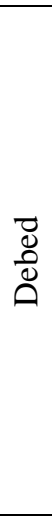 } & $\begin{array}{c}0.5 \mathrm{~km} \\
\text { downstreak } \\
\text { Martsiget river } \\
\text { intake }\end{array}$ & $\begin{array}{c}\text { (III) } \\
\text { moderate }\end{array}$ & $\begin{array}{l}\text { Ammonium and } \\
\text { phosphate ions }\end{array}$ & $\begin{array}{l}\text { Uncentralized } \\
\text { domestic } \\
\text { wastewaters, } \\
\text { return flows } \\
\text { from } \\
\text { agriculture }\end{array}$ \\
\hline & $\begin{array}{l}0.5 \mathrm{~km} \text { upstream } \\
\text { Ayrum village }\end{array}$ & $\begin{array}{c}\text { (III) } \\
\text { moderate }\end{array}$ & $\begin{array}{l}\text { Copper and } \\
\text { phosphate ion }\end{array}$ & \multirow{2}{*}{$\begin{array}{l}\text { Wastewater of } \\
\text { Akhtala mine, } \\
\text { uncentralized } \\
\text { domestic } \\
\text { wastewaters } \\
\end{array}$} \\
\hline & Near boarder & $\begin{array}{c}\text { (III) } \\
\text { moderate }\end{array}$ & $\begin{array}{l}\text { Copper and } \\
\text { phosphate ion }\end{array}$ & \\
\hline$\frac{\frac{\pi}{\pi}}{\stackrel{\frac{\pi}{\pi}}{\frac{1}{4}}}$ & near River mouth & (V) bad & $\begin{array}{l}\text { Sulphate ion, } \\
\text { zinc, copper, } \\
\text { manganese, iron } \\
\text { and cadmium }\end{array}$ & $\begin{array}{l}\text { Wastewater of } \\
\text { Akhtala mine }\end{array}$ \\
\hline $\begin{array}{l}\text { 萑 } \\
\stackrel{0}{\Xi} \\
\text { చ }\end{array}$ & near River mouth & (V) bad & $\begin{array}{l}\text { Molybdenum and } \\
\text { copper }\end{array}$ & $\begin{array}{l}\text { Wastewater of } \\
\text { the Teghut } \\
\text { Mine }\end{array}$ \\
\hline \multirow{2}{*}{$\frac{\vec{d}}{\frac{\pi}{2}}$} & $\begin{array}{c}1.2 \mathrm{~km} \text { upstream } \\
\text { Dilijan town }\end{array}$ & (II) good & All indicators & None \\
\hline & $\begin{array}{c}\text { 0.5km } \\
\text { downstream } \\
\text { Dilijan town }\end{array}$ & $\begin{array}{c}\text { (III) } \\
\text { moderate }\end{array}$ & $\begin{array}{l}\text { COD, ammonium } \\
\text { and phosphate } \\
\text { ions }\end{array}$ & $\begin{array}{l}\text { Domestic } \\
\text { wastewater of } \\
\text { Dilijan town }\end{array}$ \\
\hline
\end{tabular}




\begin{tabular}{|c|c|c|c|c|}
\hline ¿ें & $\begin{array}{l}\text { Observation } \\
\text { point }\end{array}$ & $\begin{array}{l}\text { Water } \\
\text { quality } \\
\text { class }\end{array}$ & $\begin{array}{c}\text { Hydrochemical } \\
\text { parameters } \\
\text { specified the } \\
\text { water quality } \\
\text { class }\end{array}$ & $\begin{array}{c}\text { Main factor } \\
\text { pressure- } \\
\text { impact on } \\
\text { water quality }\end{array}$ \\
\hline & $\begin{array}{l}1 \mathrm{~km} \text { upstream } \\
\text { Ijevan town }\end{array}$ & $\begin{array}{l}\text { (III) } \\
\text { moderate }\end{array}$ & Phosphate ion & $\begin{array}{l}\text { Uncentralized } \\
\text { domestic } \\
\text { wastewaters }\end{array}$ \\
\hline & Near boarder & $\begin{array}{c}\text { (III) } \\
\text { moderate }\end{array}$ & $\begin{array}{l}\text { COD and } \\
\text { phosphate ion }\end{array}$ & $\begin{array}{l}\text { Domestic } \\
\text { wastewater of } \\
\text { Ijevan town }\end{array}$ \\
\hline \multirow{5}{*}{ 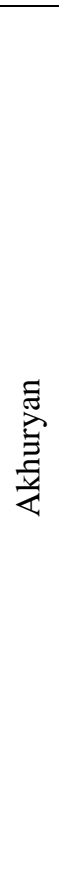 } & $\begin{array}{c}0.5 \mathrm{~km} \text { upstream } \\
\text { Amasia town }\end{array}$ & (II) good & All indicators & None \\
\hline & $\begin{array}{c}1 \mathrm{~km} \text { downstream } \\
\text { Amasia town }\end{array}$ & (II) good & All indicators & None \\
\hline & $\begin{array}{l}\text { 0.8km upstream } \\
\text { Gyumri town }\end{array}$ & $\begin{array}{c}\text { (III) } \\
\text { moderate }\end{array}$ & $\begin{array}{l}\text { Ammonium and } \\
\text { phosphate ions }\end{array}$ & $\begin{array}{l}\text { Uncentralized } \\
\text { domestic } \\
\text { wastewaters, } \\
\text { return flows } \\
\text { from } \\
\text { agriculture }\end{array}$ \\
\hline & $\begin{array}{c}\text { 5km downstream } \\
\text { Gyumri town }\end{array}$ & (IV) poor & $\begin{array}{l}\text { Ammonium and } \\
\text { phosphate ions }\end{array}$ & $\begin{array}{l}\text { Domestic } \\
\text { wastewater of } \\
\text { Gyumri town }\end{array}$ \\
\hline & $\begin{array}{c}0.5 \mathrm{~km} \\
\text { downstream } \\
\text { Yervandashat } \\
\text { villahe }\end{array}$ & $\begin{array}{c}\text { (III) } \\
\text { moderate }\end{array}$ & Phosphate ion & $\begin{array}{l}\text { Uncentralized } \\
\text { domestic } \\
\text { wastewaters, } \\
\text { return flows } \\
\text { from } \\
\text { agriculture }\end{array}$ \\
\hline
\end{tabular}




\begin{tabular}{|c|c|c|c|c|}
\hline ڤે & $\begin{array}{c}\text { Observation } \\
\text { point }\end{array}$ & $\begin{array}{l}\text { Water } \\
\text { quality } \\
\text { class }\end{array}$ & $\begin{array}{c}\text { Hydrochemical } \\
\text { parameters } \\
\text { specified the } \\
\text { water quality } \\
\text { class }\end{array}$ & $\begin{array}{c}\text { Main factor } \\
\text { pressure- } \\
\text { impact on } \\
\text { water quality }\end{array}$ \\
\hline 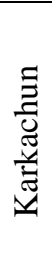 & near River mouth & (V) bad & $\begin{array}{l}\text { Dissolved } \\
\text { oxygen, } \\
\text { ammonium, } \\
\text { nitrite and } \\
\text { phosphate ions }\end{array}$ & $\begin{array}{l}\text { Uncentralized } \\
\text { domestic } \\
\text { wastewaters, } \\
\text { return flows } \\
\text { from } \\
\text { agriculture }\end{array}$ \\
\hline \multirow{3}{*}{ 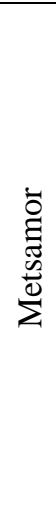 } & $\begin{array}{l}\text { 10km south of } \\
\text { Vagharshapat } \\
\text { town }\end{array}$ & $\begin{array}{c}\text { (III) } \\
\text { moderate }\end{array}$ & $\begin{array}{l}\text { COD, } \\
\text { Ammonium and } \\
\text { phosphate ions }\end{array}$ & $\begin{array}{l}\text { Return flows } \\
\text { from ponds } \\
\text { and swamps }\end{array}$ \\
\hline & $\begin{array}{c}11 \mathrm{~km} \text { south-east } \\
\text { of Vagharshapat } \\
\text { town }\end{array}$ & (IV) poor & $\begin{array}{l}\text { COD, ammonium, } \\
\text { nitrite and } \\
\text { phosphate ions }\end{array}$ & \multirow{2}{*}{$\begin{array}{l}\text { Return flows } \\
\text { from ponds } \\
\text { and swamps } \\
\text { domestic } \\
\text { wastewaters, } \\
\text { return flows } \\
\text { from } \\
\text { agriculture }\end{array}$} \\
\hline & $\begin{array}{c}0.5 \mathrm{~km} \\
\text { downstream } \\
\text { Ranchpar village }\end{array}$ & (IV) poor & $\begin{array}{l}\text { COD, ammonium, } \\
\text { nitrite and } \\
\text { phosphate ions }\end{array}$ & \\
\hline \multirow[b]{2}{*}{ 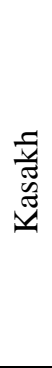 } & $\begin{array}{l}\text { 0.5km upstream } \\
\text { Aparan town }\end{array}$ & (II) good & All indicators & None \\
\hline & $\begin{array}{c}0.5 \mathrm{~km} \\
\text { downstream } \\
\text { Aparan town }\end{array}$ & $\begin{array}{c}\text { (III) } \\
\text { moderate }\end{array}$ & $\begin{array}{l}\text { Ammonium and } \\
\text { phosphate ions }\end{array}$ & $\begin{array}{l}\text { Uncentralized } \\
\text { domestic } \\
\text { wastewaters, } \\
\text { return flows } \\
\text { from } \\
\text { agriculture }\end{array}$ \\
\hline \multirow{2}{*}{ 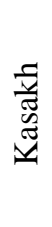 } & $\begin{array}{l}\text { 1km upstream } \\
\text { Ashtarak town }\end{array}$ & (II) good & All indicators & None \\
\hline & $\begin{array}{c}3.5 \mathrm{~km} \\
\text { downstream } \\
\text { Ashtarak town }\end{array}$ & $\begin{array}{c}\text { (III) } \\
\text { moderate }\end{array}$ & $\begin{array}{l}\text { Ammonium and } \\
\text { phosphate ions }\end{array}$ & $\begin{array}{l}\text { Uncentralized } \\
\text { domestic } \\
\text { wastewaters }\end{array}$ \\
\hline
\end{tabular}




\begin{tabular}{|c|c|c|c|c|}
\hline ¿े & $\begin{array}{c}\text { Observation } \\
\text { point }\end{array}$ & $\begin{array}{l}\text { Water } \\
\text { quality } \\
\text { class }\end{array}$ & $\begin{array}{c}\text { Hydrochemical } \\
\text { parameters } \\
\text { specified the } \\
\text { water quality } \\
\text { class }\end{array}$ & $\begin{array}{c}\text { Main factor } \\
\text { pressure- } \\
\text { impact on } \\
\text { water quality }\end{array}$ \\
\hline & near River mouth & (IV) poor & $\begin{array}{l}\text { COD, nitrite, } \\
\text { nitrate and } \\
\text { phosphate ions }\end{array}$ & $\begin{array}{l}\text { Uncentralized } \\
\text { domestic } \\
\text { wastewaters, } \\
\text { return flows } \\
\text { from } \\
\text { agriculture }\end{array}$ \\
\hline \multirow{5}{*}{ 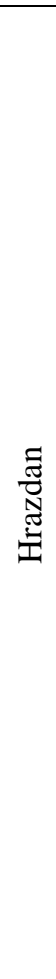 } & $\begin{array}{c}0.5 \mathrm{~km} \\
\text { downstream } \\
\text { Khaghsi village }\end{array}$ & (II) good & All indicators & None \\
\hline & $\begin{array}{c}0.5 \mathrm{~km} \\
\text { downstream } \\
\text { Argel village }\end{array}$ & (II) good & All indicators & None \\
\hline & $\begin{array}{c}0.5 \mathrm{~km} \\
\text { downstream } \\
\text { Arzni HPP }\end{array}$ & $\begin{array}{c}\text { (III) } \\
\text { moderate }\end{array}$ & $\begin{array}{l}\text { Ammonium and } \\
\text { phosphate ions }\end{array}$ & $\begin{array}{l}\text { Uncentralized } \\
\text { domestic } \\
\text { wastewaters, } \\
\text { return flows } \\
\text { from } \\
\text { agriculture }\end{array}$ \\
\hline & $\begin{array}{c}\text { Near Geghanist } \\
\text { village }\end{array}$ & (V) bad & \multirow{2}{*}{$\begin{array}{l}\mathrm{BOD}_{5}, \mathrm{COD}, \\
\text { dissolved oxygen, } \\
\text { ammonium, } \\
\text { nitrite, phosphate } \\
\text { ions, manganese, } \\
\text { vanadium }\end{array}$} & $\begin{array}{l}\text { Domestic } \\
\text { wastewater of } \\
\text { Yerevan city, } \\
\text { solid waste }\end{array}$ \\
\hline & $\begin{array}{c}\text { 6km downstream } \\
\text { Yerevan city, } \\
\text { near Darbnik } \\
\text { village }\end{array}$ & (V) bad & & $\begin{array}{l}\text { Domestic } \\
\text { wastewater of } \\
\text { Yerevan city, } \\
\text { solid waste }\end{array}$ \\
\hline
\end{tabular}




\begin{tabular}{|c|c|c|c|c|}
\hline ఏे & $\begin{array}{c}\text { Observation } \\
\text { point }\end{array}$ & $\begin{array}{l}\text { Water } \\
\text { quality } \\
\text { class }\end{array}$ & $\begin{array}{c}\text { Hydrochemical } \\
\text { parameters } \\
\text { specified the } \\
\text { water quality } \\
\text { class }\end{array}$ & $\begin{array}{l}\text { Main factor } \\
\text { pressure- } \\
\text { impact on } \\
\text { water quality }\end{array}$ \\
\hline & near River mouth & (V) bad & $\begin{array}{l}\text { Ammonium and } \\
\text { phosphate ions } \\
\text { and vanadium }\end{array}$ & $\begin{array}{l}\text { Uncentralized } \\
\text { domestic } \\
\text { wastewaters, } \\
\text { return flows } \\
\text { from } \\
\text { agriculture }\end{array}$ \\
\hline 茕 & near River mouth & (V) bad & $\begin{array}{l}\text { Ammonium and } \\
\text { phosphate ions } \\
\text { and vanadium }\end{array}$ & $\begin{array}{l}\text { Domestic } \\
\text { wastewater of } \\
\text { Yerevan city, } \\
\text { solid waste }\end{array}$ \\
\hline \multirow{2}{*}{ 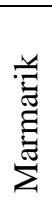 } & $\begin{array}{c}0.5 \mathrm{~km} \text { upstream } \\
\text { Hankhavan } \\
\text { village }\end{array}$ & (II) good & All indicators & None \\
\hline & near River mouth & (II) good & All indicators & None \\
\hline \multirow[b]{2}{*}{ 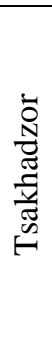 } & $\begin{array}{l}0.5 \mathrm{~km} \text { upstream } \\
\text { Tsakhadzor town }\end{array}$ & (II) good & All indicators & None \\
\hline & $\begin{array}{c}0.5 \mathrm{~km} \\
\text { downstream } \\
\text { Tsakhadzor town }\end{array}$ & (IV) poor & $\begin{array}{l}\text { Ammonium and } \\
\text { phosphate ions }\end{array}$ & $\begin{array}{l}\text { Domestic } \\
\text { wastewater of } \\
\text { Tsakhadzorto } \\
\text { wn and rest } \\
\text { houses }\end{array}$ \\
\hline \multirow[b]{2}{*}{ 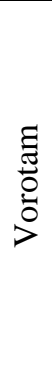 } & $\begin{array}{l}0.5 \mathrm{~km} \text { upstream } \\
\text { Gorhaikh village }\end{array}$ & (II) good & All indicators & None \\
\hline & $\begin{array}{l}1 \mathrm{~km} \text { upstream } \\
\text { Sisian town }\end{array}$ & (IV) poor & Phosphate ion & $\begin{array}{l}\text { Uncentralized } \\
\text { domestic } \\
\text { wastewaters, } \\
\text { return flows } \\
\text { from } \\
\text { agriculture }\end{array}$ \\
\hline
\end{tabular}




\begin{tabular}{|c|c|c|c|c|}
\hline ¿े̀ & $\begin{array}{c}\text { Observation } \\
\text { point }\end{array}$ & $\begin{array}{l}\text { Water } \\
\text { quality } \\
\text { class }\end{array}$ & $\begin{array}{c}\text { Hydrochemical } \\
\text { parameters } \\
\text { specified the } \\
\text { water quality } \\
\text { class }\end{array}$ & $\begin{array}{l}\text { Main factor } \\
\text { pressure- } \\
\text { impact on } \\
\text { water quality }\end{array}$ \\
\hline & $\begin{array}{c}2 \mathrm{~km} \text { downstream } \\
\text { Sisian town }\end{array}$ & (IV) poor & Phosphate ion & $\begin{array}{l}\text { Domestic } \\
\text { wastewaters of } \\
\text { downstream } \\
\text { settlements } \\
\text { and Sisian } \\
\text { town }\end{array}$ \\
\hline & $\begin{array}{c}0.5 \mathrm{~km} \\
\text { downstream the } \\
\text { Tatev HPP }\end{array}$ & $\begin{array}{c}\text { (III) } \\
\text { oderate }\end{array}$ & Phosphate ion & $\begin{array}{l}\text { Uncentralized } \\
\text { domestic } \\
\text { wastewaters, } \\
\text { return flows } \\
\text { from } \\
\text { agriculture }\end{array}$ \\
\hline \multirow{2}{*}{ 胥 } & $\begin{array}{c}0.5 \mathrm{~km} \text { upstream } \\
\text { Arevis village }\end{array}$ & (II) good & All indicators & None \\
\hline & $\begin{array}{l}\text { Near Tolors } \\
\text { Reservoir }\end{array}$ & (II) good & All indicators & None \\
\hline \multirow{2}{*}{ 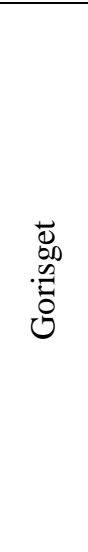 } & $\begin{array}{l}3 \mathrm{~km} \text { upstream } \\
\text { Goris town }\end{array}$ & (IV) poor & Phosphate ion & $\begin{array}{l}\text { Uncentralized } \\
\text { domestic } \\
\text { wastewaters, } \\
\text { return flows } \\
\text { from } \\
\text { agriculture }\end{array}$ \\
\hline & $\begin{array}{c}1.5 \mathrm{~km} \\
\text { downstream } \\
\text { Goris town }\end{array}$ & (V) bad & $\begin{array}{l}\text { Ammonium and } \\
\text { phosphate ions }\end{array}$ & $\begin{array}{l}\text { Domestic } \\
\text { wastewaters of } \\
\text { upstream } \\
\text { settlements } \\
\text { and Goris } \\
\text { town }\end{array}$ \\
\hline 美 & $\begin{array}{c}\text { Upstream } \\
\text { Dastakert mine }\end{array}$ & (II) good & All indicators & None \\
\hline
\end{tabular}




\begin{tabular}{|c|c|c|c|c|}
\hline $\begin{array}{l}\bar{\nu} \\
\dot{\vec{z}}\end{array}$ & $\begin{array}{c}\text { Observation } \\
\text { point }\end{array}$ & $\begin{array}{l}\text { Water } \\
\text { quality } \\
\text { class }\end{array}$ & $\begin{array}{c}\text { Hydrochemical } \\
\text { parameters } \\
\text { specified the } \\
\text { water quality } \\
\text { class }\end{array}$ & $\begin{array}{c}\text { Main factor } \\
\text { pressure- } \\
\text { impact on } \\
\text { water quality }\end{array}$ \\
\hline & $\begin{array}{c}\text { Near Dastakert } \\
\text { mine }\end{array}$ & (V) bad & Molybdenum & $\begin{array}{l}\text { Surface water } \\
\text { flow from non } \\
\text { operated } \\
\text { Dastakert } \\
\text { Copper- } \\
\text { Molybdenum } \\
\text { Mine and } \\
\text { Tailings pond } \\
\text { area }\end{array}$ \\
\hline$\stackrel{\vec{D}}{\stackrel{.00}{\rightleftarrows}}$ & $\begin{array}{l}\text { Downstream } \\
\text { Soflu village, } \\
\text { 100m upstream } \\
\text { of the Kishkosht } \\
\text { river intake }\end{array}$ & (II) good & All indicators & None \\
\hline 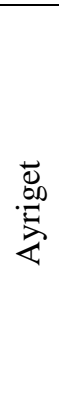 & $\begin{array}{l}100 \mathrm{~m} \\
\text { downstream of } \\
\text { the Kishkosht } \\
\text { river intake }\end{array}$ & (V) bad & Molybdenum & $\begin{array}{l}\text { Surface water } \\
\text { flow from non } \\
\text { operated } \\
\text { Dastakert } \\
\text { Copper- } \\
\text { Molybdenum } \\
\text { Mine and } \\
\text { Tailings pond } \\
\text { area }\end{array}$ \\
\hline \multirow{2}{*}{$\begin{array}{l}:= \\
\frac{7}{60} \\
8 \\
>\end{array}$} & $\begin{array}{c}1.7 \mathrm{~km} \text { upstream } \\
\text { Kajaran town }\end{array}$ & (II) good & All indicators & None \\
\hline & $\begin{array}{c}1.8 \mathrm{~km} \\
\text { downstream } \\
\text { Kajaran town }\end{array}$ & $(\mathrm{V})$ bad & $\begin{array}{l}\text { Ammonium and } \\
\text { phosphate ions }\end{array}$ & $\begin{array}{l}\text { Domestic } \\
\text { wastewater of } \\
\text { Khajaran town }\end{array}$ \\
\hline
\end{tabular}




\begin{tabular}{|c|c|c|c|c|}
\hline ఏे̃ & $\begin{array}{c}\text { Observation } \\
\text { point }\end{array}$ & $\begin{array}{l}\text { Water } \\
\text { quality } \\
\text { class }\end{array}$ & $\begin{array}{c}\text { Hydrochemical } \\
\text { parameters } \\
\text { specified the } \\
\text { water quality } \\
\text { class }\end{array}$ & $\begin{array}{l}\text { Main factor } \\
\text { pressure- } \\
\text { impact on } \\
\text { water quality }\end{array}$ \\
\hline & $\begin{array}{l}0.8 \mathrm{~km} \text { upstream } \\
\text { Kapan town }\end{array}$ & $\begin{array}{c}\text { (III) } \\
\text { moderate }\end{array}$ & $\begin{array}{l}\text { Vanadium, iron, } \\
\text { manganese, } \\
\text { cobalt, } \\
\text { molybdenum, } \\
\text { antimon }\end{array}$ & $\begin{array}{l}\text { Wastewater of } \\
\text { Khajaran } \\
\text { mine, surface } \\
\text { water flow } \\
\text { formed from } \\
\text { open mine } \\
\text { area }\end{array}$ \\
\hline & $\begin{array}{c}\text { Near Kapan } \\
\text { airport }\end{array}$ & (V) bad & $\begin{array}{l}\text { Manganese, } \\
\text { cobalt and copper }\end{array}$ & \multirow{2}{*}{$\begin{array}{l}\text { Polluted } \\
\text { waters of } \\
\text { Artsvanik, } \\
\text { Norashenik } \\
\text { and Kavart } \\
\text { tributaries }\end{array}$} \\
\hline & $\begin{array}{c}6.8 \mathrm{~km} \\
\text { downstream } \\
\text { Kapan town }\end{array}$ & (V) bad & $\begin{array}{l}\text { Manganese, } \\
\text { cobalt, copper and } \\
\text { molybdenum }\end{array}$ & \\
\hline \multirow[b]{2}{*}{ 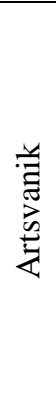 } & $\begin{array}{l}\text { Downstream } \\
\text { tailing pond }\end{array}$ & $\begin{array}{c}\text { (III) } \\
\text { moderate }\end{array}$ & $\begin{array}{l}\text { Sodium, } \\
\text { vanadium, iron, } \\
\text { cobalt }\end{array}$ & $\begin{array}{l}\text { Natural } \\
\text { condition }\end{array}$ \\
\hline & near River mouth & (V) bad & $\begin{array}{l}\text { Elements of } \\
\text { Mineralization } \\
\text { regime } \\
\left(\mathrm{Na}, \mathrm{K}, \mathrm{SO}_{4}{ }^{2-}\right) \text { and } \\
\text { heavy metals } \\
(\mathrm{Mn}, \mathrm{Mo}, \mathrm{Sb})\end{array}$ & $\begin{array}{l}\text { Wastewater of } \\
\text { Artsvanik } \\
\text { mine }\end{array}$ \\
\hline \multirow{3}{*}{$\begin{array}{l}-17 \\
000 \\
0\end{array}$} & $\begin{array}{c}0.5 \mathrm{~km} \text { upstream } \\
\text { Ajabaj village }\end{array}$ & (II) good & All indicators & None \\
\hline & $\begin{array}{l}\text { Near Ajabaj } \\
\text { village }\end{array}$ & (V) bad & Manganese & $\begin{array}{l}\text { Return flows } \\
\text { from tailing } \\
\text { ponds of the } \\
\text { «Ler-Ex» Ltd }\end{array}$ \\
\hline & near River mouth & (II) good & All indicators & None \\
\hline
\end{tabular}




\begin{tabular}{|c|c|c|c|c|}
\hline ఏे̃ & $\begin{array}{c}\text { Observation } \\
\text { point }\end{array}$ & $\begin{array}{l}\text { Water } \\
\text { quality } \\
\text { class }\end{array}$ & $\begin{array}{c}\text { Hydrochemical } \\
\text { parameters } \\
\text { specified the } \\
\text { water quality } \\
\text { class }\end{array}$ & $\begin{array}{l}\text { Main factor } \\
\text { pressure- } \\
\text { impact on } \\
\text { water quality }\end{array}$ \\
\hline 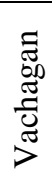 & In Kapan town & (II) good & All indicators & None \\
\hline$\stackrel{\vec{B}}{\mathscr{H}}$ & Near Tsav village & (II) good & All indicators & None \\
\hline \multirow{4}{*}{ 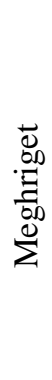 } & Near river source & (II) good & All indicators & None \\
\hline & $\begin{array}{c}0.5 \mathrm{~km} \\
\text { downstream } \\
\text { Tkhkut village }\end{array}$ & (V) bad & $\begin{array}{l}\text { Chromium, iron, } \\
\text { manganese, } \\
\text { cobalt, nickel }\end{array}$ & $\begin{array}{l}\text { Wastewater of } \\
\text { Litchqvaz-Tey } \\
\text { mine }\end{array}$ \\
\hline & $\begin{array}{l}\text { 0.5km upstream } \\
\text { Meghri town }\end{array}$ & (II) good & All indicators & None \\
\hline & near River mouth & (II) good & All indicators & None \\
\hline \multirow[t]{2}{*}{ 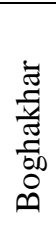 } & $\begin{array}{l}\text { At middlestream, } \\
\text { upstream } \\
\text { Litchqvaz-Tey } \\
\text { mine }\end{array}$ & (II) good & All indicators & None \\
\hline & near River mouth & (II) good & All indicators & None \\
\hline 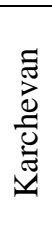 & near River mouth & (V) bad & $\begin{array}{l}\text { Elements of } \\
\text { Mineralization } \\
\text { regime, heavy } \\
\text { metals, organic } \\
\text { substances }\end{array}$ & $\begin{array}{l}\text { Wastewater of } \\
\text { Agarak mine }\end{array}$ \\
\hline
\end{tabular}




\subsection{Water quality indexs}

The suitability of water sources for human consumption has been described in terms of Water quality index (WQI), which is one of the most effective ways to describe the quality of water. WQI utilizes the water quality data and helps in the modification of the policies, which are formulated by various environmental monitoring agencies. WQI has the capability to reduce the bulk of the information into a single value and it takes information from a number of sources and combines them to develop an overall status of a water system. The WQI is a mathematical instrument used to transform large quantities of water quality data into a single number; which improves understanding of water quality issues. This is done by integrating relevant water quality data, to generate a score that describes water quality status and can also be used to evaluate water quality trends.

Water quality index provides a single number that expresses overall water quality at a certain location and time, based on several water quality parameters. The objective of water quality index is to turn complex water quality data into information that is understandable and usable by the public.

Water quality of any specific area or specific source can be assessed using physical, chemical and biological parameters. The values of these parameters are harmful for human health if they occurred more than defined limits. Different Water quality indices have been developed worldwide which are greatly differing in terms of mathematical structures, the numbers and types of variables included, etc. 
The present study reviews some of the important Water quality index and water quality indicesand provides their mathematical formula, set of parameters and calculations. Considering the simplicity and scientific basis of WQI, it is expected that these indices will provide meaningful summaries of overall water quality and possibly trends. While appreciating the importance and usability of WQI, it is important to understand the limitations of WQI. The WQI are not intended to replace a detailed analysis of environmental monitoring and modeling, nor should they be the sole tool for the management of water bodies. However, WQI can be used to provide a broad overview of environmental performance that can be conveyed to the public in an easy to understand format. The many advantages of these indices include their ability to represent measurements of a variety of variables in a single number; the ability to combine various measurements with a variety of measurement units in a single metric; and the facilitation of communication of the results. On the other hand, there are limitations in the use of WQI: the loss of information by combining several variables to a single index value; the sensitivity of the results to the formulation of the index; the loss of information on interactions between variables; and the lack of portability of the index to different ecosystems.

The study of ecological status of the rivers in Armenia is important for evaluation of their water quality, as well as for their further rational use. Currently, hydrological practice actively uses several dozen indices. It must be noted that most developing complex characteristics of water object in one way or another is connected with the existing maximum permissible concentration It must be noted that most developing complex 
characteristics of water object in one way or another is connected with the existing maximum permissible concentration.

\subsubsection{Horton Water Quality Index (HWQI)}

WQI was developed by Horton (1965) in United States by selecting 10 most commonly used water quality variables like dissolved oxygen (DO), $\mathrm{pH}$, coliforms, specific conductance, alkalinity and chloride etc. and has been widely applied and accepted in European, African and Asian countries. Horton put the rating scales and the weightings for the determinants to give the relative importance of each parameter in the water quality:

$$
H W Q I=\frac{\sum_{i=1}^{n} C_{i} W_{i}}{\sum_{i=1}^{n} W_{i}} M_{1} M_{2},
$$

where: HWQI: water quality index; $\mathrm{C}_{\mathrm{i}}$ : the rating of the ith determinant; $\mathrm{W}_{\mathrm{i}}$ : the weighting of the ith determinant; $\mathrm{n}$ : number of determinants; $\mathrm{M}_{1}, \mathrm{M}_{2}$ : additional determinant parameters [45].

\subsubsection{National Sanitation Foundation Water Quality Index (NSFWQI)}

The assigned weight reflected significance of a parameter for a particular use and has considerable impact on the index. Furthermore, a new WQI similar to Horton's index has also been developed by the group of Brown in 1970, which was based on weights to individual parameter. Recently, many modifications have been considered for WQI concept through various scientists and experts. 
A usual water quality index method was developed by paying great rigor in selecting parameters, developing a common scale and assigning weights. The attempt was supported by the National Sanitation Foundation (NSF) and therefore as NSFWQI in order to calculate WQI of various water bodies critically polluted. The proposed method for comparing the water quality of various water sources is based upon nine water quality parameters such as temperature, $\mathrm{pH}$, turbidity, fecal coliform, dissolved oxygen, biochemical oxygen demand, total phosphates, nitrates and total solids. The water quality data are recorded and transferred to a weighting curve chart, where a numerical value of $\mathrm{Q}_{\mathrm{i}}$ is obtained. The mathematical expression for NSF WQI is given by.

$$
N S F W Q I=\sum_{i=1}^{n} Q_{i} W_{i}
$$

where, $Q_{i}=$ sub-index for ith water quality parameter; $W_{i}=$ weight associated with ith water quality parameter; $n=$ number of water quality parameters. For this NSFWQI method, the ratings of water quality have been defined by using following [46-47]:

Table 2.2

Classes of water quality depending on the value of the NSFWQI.

\begin{tabular}{|c|c|c|}
\hline NSFWQI Value & Rating of Water Quality & $\begin{array}{c}\text { Water quality } \\
\text { classes }\end{array}$ \\
\hline $0-25$ & Excellent water quality & A \\
\hline $26-50$ & Good water quality & B \\
\hline $51-75$ & Poor water quality & D \\
\hline $76-100$ & Very Poor water quality & E \\
\hline Above 100 & $\begin{array}{l}\text { Unsuitable for drinking } \\
\text { purpose }\end{array}$ \\
\hline
\end{tabular}




\subsubsection{Canadian Council of Ministers of the Environment Water Quality Index (CWQI)}

CWQI provides a consistent method, which was formulated by Canadian jurisdictions to convey the water quality information for both management and the public. Moreover, a committee established under the Canadian Council of Ministers of the Environment (CCME) has developed WQI, which can be applied by many water agencies in various countries with slight modification. This method has been developed to evaluate surface water for protection of aquatic life in accordance to specific guidelines. The parameters related with various measurements may vary from one station to the other and sampling protocol requires atleast four parameters, sampled atleast four times. The calculation of index scores in CWQI method can be obtained by using the following relation [48]:

$$
C W Q I=100-\frac{\sqrt{F_{1}^{2}+F_{2}^{2}+F_{3}^{2}}}{1.732},
$$

where,

Scope $\left(F_{1}\right)=$ Number of variables, whose objectives are not met. $\mathrm{F}_{1}=$ [No.of failed variables /Total no. of variables $] * 100$ Frequency $\left(\mathrm{F}_{2}\right)=$ Number of times by which the objectives are not met. $F_{2}=[\text { No.of failed tests/Total no. of tests }]^{*} 100$ Amplitude $\left(\mathrm{F}_{3}\right)=$ Amount by which the objectives are not met.

(a) excursion $_{i}=[$ Failed test valuei /Objectivej $]-1$

(b) normalized sum of excursions (nse) $=$ $\sum_{i=1}^{n}$ excursionsi /No of tests

(c) $\mathrm{F}_{3}=[\mathrm{nse} / 0.01 \mathrm{nse}+0.01]$ 
Therefore, five categories have been suggested to categorize the water qualities which are summarized in Table 2.3.

Table 2.3.

Classes of water quality depending on the value of the CWQI.

\begin{tabular}{|c|c|c|}
\hline CWQI Value & $\begin{array}{c}\text { Rating of Water } \\
\text { Quality }\end{array}$ & Water quality classes \\
\hline $95-100$ & Excellent water quality & 1 \\
\hline $80-94$ & Good water quality & 2 \\
\hline $60-79$ & Fair water quality & 3 \\
\hline $45-59$ & Marginal water quality & 4 \\
\hline $0-44$ & Poor water quality & 5 \\
\hline
\end{tabular}

\subsubsection{British Columbia Water Quality Index (BCWQI)}

The BCWQI was developed by the Canadian Ministry of Environment in 1995 as an increasing index (the index numbers increase with the increasing degree of pollution) to evaluate water quality. This index is similar to the CWQI where water quality parameters are measured and their violation is determined by comparison with a predefined limit. It provides the possibility to make a classification on the basis of all existing measurement parameters. To calculate the final index value, the following equation is used [49]:

$$
B C W Q I=\frac{\sqrt{F_{1}^{2}+F_{2}^{2}+\left(\frac{F_{3}}{3}\right)^{2}}}{1.453},
$$

The number 1.453 was selected to give assurance to the scale index number from zero to 100. It is important to note that repeated samplings and increasing stations increase the accuracy of the British Columbia index. The WQI is a number ranging from 0 to 100 divided into one of five categories: excellent 
(0-3), good (4-17), fair (18-43), borderline (44-59) and poor (60-100).

Table 2.4.

Classes of water quality depending on the value of the BCWQI.

\begin{tabular}{|c|c|c|}
\hline BCWQI Value & $\begin{array}{c}\text { Rating of Water } \\
\text { Quality }\end{array}$ & Water quality classes \\
\hline $0-3$ & Excellent water quality & 1 \\
\hline $4-17$ & Good water quality & 2 \\
\hline $18-43$ & Fair water quality & 3 \\
\hline $44-59$ & Borderlin water quality & 4 \\
\hline $60-100$ & Poor water quality & 5 \\
\hline
\end{tabular}

\subsubsection{Modified Canadian Water Quality Index (MCWQI)}

The article performs the modified aggregation of CWQI using the following modification: Scope, $\mathrm{V}_{1}$ : The percentage of failed parameters is modified using the relative weights of the parameters [49]:

$$
V_{1}=\frac{\sum P_{i} x C}{\sum P_{i}},
$$

where: $\mathrm{C}$ is a count factor of 1 or 0 . If one parameter fails $\mathrm{C}=1$, otherwise $\mathrm{C}=0$.

Frequency and amplitude, $\mathrm{V}_{2}$ : Islam et al. have combined frequency and amplitude. Another modification is done by combining the relative weights for the normalized sum of excursions (nse):

$$
n s e=\frac{\sum_{i=1}^{n} S I_{i, k} \times P_{i}}{\sum_{i=1}^{n} P_{i}},
$$

where: $\mathrm{SI}=$ sub-index value; $\mathrm{i}=$ order of parameter; $\mathrm{k}=$ order for each time step; $\mathrm{P}=$ relative weight:

$$
V_{2}=\frac{n s e}{0.005 n s e+0.005} \text {, }
$$




$$
M C W Q I=100-\frac{\sqrt{V_{1}^{2}+V_{2}^{2}}}{1.414} .
$$

The value should be from 0 to 100 Therefore, sixe categories have been suggested to categorize the water qualities which are summarized in Table 2.5.

Table 2.5 .

Classes of water quality depending on the value of the MCWQI

\begin{tabular}{|c|c|c|}
\hline CWQI Value & $\begin{array}{c}\text { Rating of Water } \\
\text { Quality }\end{array}$ & Water quality classes \\
\hline $91-100$ & Excellent water quality & 1 \\
\hline $81-90$ & Veri good water quality & 2 \\
\hline $71-80$ & Good water quality & 3 \\
\hline $51-70$ & Fair water quality & 4 \\
\hline $21-50$ & Marginal water quality & 5 \\
\hline $0-20$ & Poor water quality & 6 \\
\hline
\end{tabular}

\subsubsection{Oregon Water Quality Index (OWQI)}

The OWQI is a single number that expresses water quality by taking eight water quality variables (temperature, $\mathrm{DO}, \mathrm{pH}$, BOD, total phosphorus, total solids, fecal coliform, ammonia and nitrate nitrogen) into account. The original OWQI was designed after the NSFWQI where the Delphi method was used for variable selection. Both indices used logarithmic transforms to convert water quality variable results into sub-index (SI) values. Logarithmic transforms take advantage of the fact that a change in magnitude at lower levels of impairment has a greater impact than an equal change in magnitude at higher levels of impairment. 
OWQI creates a score to evaluate the general water quality of Oregon's stream and the application of this method to other geographic regions, which combines eight water quality variables into a single number. The parameters covered in this method are temperature, dissolved oxygen (DO), biochemical oxygen demand $\left(\mathrm{BOD}_{5}\right), \mathrm{pH}$, ammonia and nitrate nitrogen, total phosphorus, total solids and fecal coliform. The original OWQI was designed after the NSFWQI where the Delphi method was used for variable selection. It expresses water quality status and trends for the legislatively mandated water quality status assessment. The index is free from the arbitration in weighting the parameters and employs the concept of harmonic averaging. The mathematical expression of this WQI method is given by [50-51]:

$$
O W Q I=\sqrt{\frac{n}{\sum_{i}^{n} \frac{1}{S I^{2}}}},
$$

where, $n$ - number of subindices, $S I$ - subindex of ith parameter Furthermore, the rating scale of this OWQI has also been categorized in various classes, which are given under Table 2.6.

Table 2.6.

Classes of water quality depending on the value of the OWQI

\begin{tabular}{|c|c|c|}
\hline OWQI Value & $\begin{array}{c}\text { Rating of Water } \\
\text { Quality }\end{array}$ & Water quality classes \\
\hline $90-100$ & Excellent water quality & 1 \\
\hline $85-89$ & Good water quality & 2 \\
\hline $80-84$ & Fair water quality & 3 \\
\hline $60-79$ & Poor water quality & 4 \\
\hline $0-59$ & Very poor water quality & 5 \\
\hline
\end{tabular}




\subsubsection{Malaysia Water Quality Index (MWQI)}

The MWQI is the WQI calculation method developed by the Department of Environment Malaysia. This method has been successfully applied to measure water quality for 462 rivers in Malaysia. The calculation involved six water parameters which are $\mathrm{DO}, \mathrm{BOD}_{5}, \mathrm{COD}$, ammonical nitrogen (AN), suspended solids (SS), and $\mathrm{pH}$. The procedure of calculation consists of three steps: to identify the SI equation based on the value of parameters, to calculate the SI of every parameter, and to calculate the WQI. Water quality can be ranked as polluted (0-59), slightly polluted (60-80), or excellent (81-100), according to the DOE scale (DOE 2013).

The formula used for calculating the DOEWQI is described as follows:

$$
\begin{aligned}
& \mathrm{MWQI}=0.22 \cdot \mathrm{SI}_{\mathrm{DO}}+0.19 \cdot \mathrm{SI}_{\mathrm{BOD}}+0.16 \cdot \mathrm{SI}_{\mathrm{COD}}+0.15 \cdot \mathrm{SI}_{\mathrm{AN}}+ \\
& +0.16 \cdot \mathrm{SI}_{\mathrm{SS}}+0.12 \cdot \mathrm{SI}_{\mathrm{PH}}
\end{aligned}
$$

where $\mathrm{SI}_{\mathrm{DO}}$ is Sub-index of DO, $\mathrm{SI}_{\mathrm{BOD}}$ - Sub-index of $\mathrm{BOD}_{5}$, $\mathrm{SI}_{\mathrm{COD}}$ - Sub-index of COD, SI $\mathrm{SS}_{\mathrm{SS}}$ - Sub-index of SS, SI $\mathrm{AN}_{\mathrm{AN}}$ - Subindex of $\mathrm{AN}$, and $\mathrm{SI}_{\mathrm{pH}}$ - Sub-index of $\mathrm{pH}$ [52-53].

\subsubsection{Dinius Water Quality Index (DWQI)}

It is a multiplicative WQI developed by Dinius for six categories of water uses: public water supply, recreation, fish, shellfish, agriculture and industry. He employed the liberal use of Delphi for decision making. The index included 12 parameters: $\mathrm{DO}, \mathrm{BOD}_{5}$, coliform count, Escherichia coli count, 
$\mathrm{pH}$, alkalinity, hardness, chloride, specific conductivity, temperature, color and nitrate. The weightage of each parameter was assigned based on the evaluation of importance by the Delphi panel members. Water quality can be ranked as not acceptable (0-40), doubtful (40-50), necessary treatment becoming more expensive (50-80), minor purification required (80-90), or purification not necessary (90-100), according to the DWQI scale. The individual SI functions were combined with the help of a multiplicative aggregation function as follows:

$$
D W Q I=\sum_{i=1}^{n} I_{i} W_{i}
$$

where $I_{i}$ is the sub-index function of the pollutant parameter, $W_{i}$ is the unit weight of the pollutant parameter whose value ranges from $0-1$ and $\mathrm{n}$ is the number of pollutant parameters (see Dinius for details) [54-56].

\subsubsection{Bascarón Water Quality Index (BWQI)}

The Bascarón index was developed by Bascarón (1979) specifically for Spain. This index has been used in several studies, particularly from South American countries, in India and in New Zealand:

$$
B W Q I=\frac{\sum_{i=1}^{n} C_{i} x P_{i}}{\sum_{i=1}^{n} P_{i}}
$$

where BWQI is the aggregated index, $n$ is number of parameters, $C i$ is the sub-index value (called normalization factorin Bascarón index)and $P i$ is the relative weight of each parameter. Details of the method used for calcu-lating $C i$ are presented later, when the Bascarón index isdiscussed in detail However it was recommended that twenty-six parameters be 
considered in the final index aggregation. Generation of subindices were obtained by normalising the actual parameter values to a common scale ranging from $0-100$. Using the normalisation factors, the sub-indices can take one of the values from $[0,10,20,30,40,50,60,70,80,90$, and 100]. Establishing weights In the Bascarón index, different weights are assigned for different parameters. The values of weights vary from 1 to 4, with the sum of all weights being 54. This subindices had weights as presented in brackets - $\mathrm{pH}(1), \mathrm{BOD}_{5}(3)$, DO (4), temperature (1), TC (3), colour (2), turbidity (4), permanganate reduction (3), detergents (4), hardness (1), DO (2), pesticides (2), oil and grease (2), $\mathrm{SO}_{4}^{-2}$ (2), $\mathrm{NO}_{3}^{-}(2)$, cyanides (2), sodium (1), free $\mathrm{CO}_{2}$ (3), ammonia $-\mathrm{N}(3), \mathrm{Cl}$ (1), conductivity (4), $\mathrm{Mg}$ (1), $\mathrm{P}(1), \mathrm{NO}_{2}$ (2), $\mathrm{Ca}$ (1) and apparent aspect (no weight given). Index aggregation Index aggregation is undertaken using a modified version of the additive method, which was presented in Equation [16] Final index value interpretation The interpretation of the final index is done based on five categories: good (final index value from 91-100), acceptable (61-90), regular (31-60), bad (16-30) and very bad (0-15) [57-60].

\subsubsection{Scottish Research Development Department Water Quality Index (SWQI)}

In 1976, the general WQI was improved and developed by The Scottish Research Development Department (SRDD) index was developed by the Engineering Division of the SRDD based 
on steps similar to those in the NSF WQI. It is also called as the Scottish WQI. Although the SRDD index was originally developed for Scotland, it has later been modified and used to evaluate the status of water quality in several river basins from different countries (for example, Thailand and Portugal. The steps used for the application of SRDD index are as follows: It was considered as a sufficiently sensitive formula for water quality conditions in Scotland and was expressed as:

$$
S W Q I=\frac{1}{100} \sum_{i=1}^{n}\left(Q_{i} W_{i}\right)^{2} .
$$

Similar to the NSF WQI, higher values of the SRDD index indicates better overall water quality. There are seven levels of water quality status in the SRDD index, namely clean (final index from 90-100), good (80-89), good water quality with some treatment (70-79), tolerable (40-69), polluted (30-39), severely polluted (20-29), and finally water akin to piggery waste (0-19) [61-63].

\subsubsection{Taiwan Water Quality Index (TWQI). River Status Index (RSI)}

An effective gradation index for diagnosing a generalized river quality has been developed and illustrated with the case study of the Keya River in Taiwan. Furthermore, the proposed index is established for evaluating river quality around the island in general.The thirteen variables are employed, which are dissolved oxygen (DO, mg/L), organics oxygen demand $\left(\mathrm{BOD}_{5}\right.$, $\mathrm{mg} / \mathrm{L})$, ammonia nitrogen $\left(\mathrm{NH}_{3}-\mathrm{N}, \mathrm{mg} / \mathrm{L}\right)$, faecal coliforms (CFU/100 mL), turbidity (NTU), suspended solids (SS, mg/L), 
temperature $\left({ }^{\circ} \mathrm{C}\right), \mathrm{pH}$, cadmium $(\mathrm{Cd}, \mathrm{mg} / \mathrm{L})$, lead $(\mathrm{Pb}, \mathrm{mg} / \mathrm{L})$, chromium $(\mathrm{Cr}, \mathrm{mg} / \mathrm{L})$, copper $(\mathrm{Cu}, \mathrm{mg} / \mathrm{L})$ and zinc $(\mathrm{Zn}, \mathrm{mg} / \mathrm{L})$. In surface water quality, $\mathrm{DO}, \mathrm{BOD}_{5}, \mathrm{NH}_{3}-\mathrm{N}$, faecal coliforms, turbidity and SS are potential contaminants contributed by microbial communities and human activities. $\mathrm{Cd}$, $\mathrm{Pb}, \mathrm{Cr}, \mathrm{Cu}$ and $\mathrm{Zn}$ are toxic substances found to cause adverse effects on human health. Measurements of environmental monitoring variables encompass natural scales that may range from a few micrograms per litre to hundreds of grams per litre.

$$
\begin{aligned}
& T W Q I= \\
& C_{t e m} C_{p^{H}} C_{t o x}\left[\left(\sum_{i=1}^{3} I_{i} W_{i}\right) X\left(\sum_{j=1}^{2} I_{j} W_{j}\right) X\left(\sum_{k=1}^{1} I_{k}\right)\right]^{1 / 3},
\end{aligned}
$$

where, the unweighted arithmetic mean is assigned for the variables associated in the same components. Ii denotes the subindex values for the 'organics' and three variables are contained that are $\mathrm{DO}, \mathrm{BOD}_{5}$ and ammonia nitrogen $\left(\mathrm{I}_{1}\right.$ for the subindex of $\mathrm{DO}, \mathrm{I}_{2}$ for the subindex of $\mathrm{BOD}_{5}$ and $\mathrm{I}_{3}$ for the subindex of $\mathrm{NH}_{3}-\mathrm{N}$ ); $\mathrm{I}_{\mathrm{j}}$ represents the subindex values for the 'particulates', which consist of suspended solids and turbidity; $\mathrm{I}_{\mathrm{k}}$ is the measurement of faecal coliform, which represents the 'microorganisms'. In addition, the geometric mean is appointed on the extracted components. Three scaling coefficients are prefixed, which address the subindices of temperature $\left(\mathrm{C}_{\text {tem }}\right), \mathrm{pH}$ $\left(\mathrm{C}_{\mathrm{pH}}\right)$ and toxicity substances $\left(\mathrm{C}_{\mathrm{tox}}\right)$, respectively. The multipliers are commended with regards to the characteristics of effects and the rating structures of the three variables. In the majority of situations the three variables would take on a value of 100 , but water is considered injurious to human, animals and 
aquatic life and makes the recovery of water quality difficult as lower ratings are evaluated. Finally, the overall water quality index consists of the arithmetic mean, geometric mean and multiplied by three coefficients. From the proposed aggregation function, if any one of the components closes to zero, theoverall index RSI approaches to zero.

The proposed measurement RSI, applied in the Keya River shows that the quality, affected by industrial activities, causing water quality problems in Taiwan, does not significant represent the existing index [64].

\subsubsection{Overall Index of Pollution (OIP)}

Sargaonkar and Deshpande developed OIP for Indian rivers based on measurements and subsequent classification of $\mathrm{pH}$, turbidity, dissolved oxygen, $\mathrm{BOD}_{5}$, hardness, total dissolved solids, total coliforms, arsenic, and fluoride. Each water quality observation was scored as Excellent, Acceptable, Slightly Polluted, Polluted, and Heavily Polluted, according to Indian standards and/or other accepted guidelines and standards such as World Health Organization and European Community Standards. Once categorized, each observation was assigned a pollution index value and the OIP was calculated as the average of each index value given by the mathematical expression:

$$
O I P=\sum P_{i} / n
$$

where $P_{i}=$ pollution index for $i$ th parameter, $n=$ number of parameters.

Based on the status of water quality, the index value range from 0 to 100 and is classified into five categories: heavily 
polluted (0-24), poor (25-49), fair (50-74), good (75-94) and excellent (95-100). The status of water corresponding to different OWQI values is presented in Table 2.6. If the index goes down, then it indicates that some of the water quality parameters are being affected due to any particular reason and suitable measures are needed to further improve the quality of water. Thus this index may be used as a guiding rule in management of quality of surface water resources [59].

\subsubsection{Bhargava Method Water Quality Index (BMWQI)}

Bhargava Method had been used in many countries, and it is easy to deal with relative parameters for different uses by using sensitivity functions' curves which take value between zeros to one. The results were accumulated by using the geometric mean. The sensitivity functions' curves are used to evaluate the quality of river water and give the importance of any parameter for a specific use. It also give weight to every parameter ,for example; when the concentration of sulfate $\left(\mathrm{SO}_{4}^{-2}\right)$ get value $400 \mathrm{ppm}$ the sensitivity function will be very low which make water worse according to sensitivity functions' curves for drinking use, while the same concentration value can give sensitivity function equal to 0.8 for irrigation use which mean it is acceptable $80 \%$. The relative parameters for irrigation use are: dissolved solids (TDS), hydrogen number $\mathrm{pH}$, sulfate $\left(\mathrm{SO}_{4}^{-2}\right)$, sodium adsorption ratio (SAR), electrical conductivity (EC), chloride $\left(\mathrm{Cl}^{-}\right)$.

This index was used to classify rivers into five groups (table 4) and to determine the water quality index for each activity of 
different water activities depending upon the variables which effects on that activity by using geometric mean formula.

The geometric mean formula expressed as below [65-67]:

$$
B M W Q I=\left[\prod_{i=1}^{n} f_{i}\left(P_{i}\right)\right]^{1 / n} X 100,
$$

where: $\mathrm{f}_{\mathrm{i}}\left(\mathrm{P}_{\mathrm{i}}\right)$ the sensitivity function for each variable including the effect of variable weight concentration which is related to a certain activity and varies from (0-1),and $\mathrm{n}$ is the number of variables. Therefore, five categories have been suggested to categorize the water qualities which are summarized in Table 2.7.

Table 2.7.

Classes of water quality depending on the value of the BMWQI.

\begin{tabular}{|c|c|c|}
\hline BMWQI Value & $\begin{array}{c}\text { Rating of Water } \\
\text { Quality }\end{array}$ & Water quality classes \\
\hline $90-100$ & Excellent water quality & 1 \\
\hline $65-89$ & Good water quality & 2 \\
\hline $35-64$ & Acceptable water quality & 3 \\
\hline $11-34$ & Polluted water quality & 4 \\
\hline $0-10$ & Severe water quality & 5 \\
\hline
\end{tabular}

\subsubsection{Smith's Water Quality Index (SWQI)}

Smith developed an index for four water uses i.e., contact as well as non-contact. It is a hybrid of the two common index types and is based on expert opinion as well as water quality standards. The selection of parameters for each water class, developing sub indices, and assigning weightages were all done using Delphi. Index development was linked to recommend water quality standards developed for New Zealand water legislation. The minimum operator technique was used to obtain the final index score: 


$$
\mathrm{I}_{\min }=\Sigma_{\min }\left(\mathrm{I}_{\text {sub } 1}, \mathrm{I}_{\text {sub2 } 2}, \ldots \ldots . \mathrm{I}_{\text {subn }}\right)
$$

where, $I_{\min }$ equals the lowest sub index value [68-69].

\subsubsection{Aquatic toxicity Water Quality Index (ATWQI)}

The aquatic toxicity index was developed by Wepener et al. to assess the health of aquatic ecosystems. Since extensive toxicity databases are available for fishes, the toxic effects of different water quality on fishes have been employed as health indicators of the aquatic ecosystem. The physical water quality parameters employed were $\mathrm{pH}, \mathrm{DO}$ and turbidity while the chemical determinants included ammonium, total dissolved salts, fluoride, potassiumand orthophosphates, and the potentially hazardous metals chosen were total zinc, manganese, chromium, copper, lead and nickel concentrations. For the ATWQI, the aggregation technique employed was the Solway Modified Unweighted Additive Aggregation function.

$$
A T W Q I=\frac{1}{100}\left(\frac{1}{n} \sum_{i=1}^{n} q_{i}\right)^{2},
$$

where qi is the quality of the ith parameter (a value between $0-100)$ and $\mathrm{n}$ is the number of determinants in the indexing system. Water quality can be ranked as totally unsuitable for normal fish life (0-50), suitable only for hardy fish species (51-59), or suitable for all fish life (60-100) [70-71]. 


\subsubsection{The River Ganga Index of Ved Prakash et al (GWQI)}

The index was developed to evaluate the water quality profile of river Ganga in its entire stretch. The index had the weighted multiplication form and was based on the NSFWQI, with slight modifications in terms of weightages to confirm to the water quality criteria for different categories of uses as set by Central Water Pollution Board, India. Water Quality over the study period was evaluated using the River Ganga Index of Ved Prakash et al. This WQI is based on the weighted multiplication form and is given by the equation:

$$
G W Q I=\sum_{i=1}^{n} I_{i} W_{i},
$$

where $I_{i}$ is the denoter sub-index function of the pollutant parameter, $W_{i}$ is the unit weight of the pollutant parameter and $n$ is the number of pollutant parameters.

A list of parameters was selected through Delphi. Subindex values were obtained from subindex equations for different parameters. To assign weightages, significance ratings were given to all parameters. A temporary weight of 1 was assigned to parameter with highest significance rating e.g., Dissolved Oxygen. Final weight was arrived at by dividing the temporary weight by the sum of all weights [72].

\subsubsection{Catalan Water Agency Water Quality Index (CAWQI)}

The Simplified is currently applied by the Catalan water agency. It is mainly a correlation of DO, TOC, SS, and conductivity, with a weight vector of $0.30,0.25,0.25$, and 0.20 , 
respectively Water quality can be ranked as very poor (0-25), poor (26-50), medium (51-70), good (71-90) or excellent (91-100) according to the ISQA scale.

$$
\mathrm{CAWQI}=\mathrm{SI}_{\mathrm{Temp}}\left(\mathrm{SI}_{\mathrm{TOC}}+\mathrm{SI}_{\mathrm{SS}}+\mathrm{SI}_{\mathrm{DO}}+\mathrm{SI}_{\mathrm{Con}}\right) \text {, }
$$

where $\mathrm{SI}_{\mathrm{Temp}}=\mathrm{Sub}$-index temperature, $\mathrm{SI}_{\mathrm{TOC}}=\mathrm{Sub}$-index TOC, $\mathrm{SI}_{\mathrm{SS}}=$ Sub-index SS, $\mathrm{SI}_{\mathrm{DO}}=$ Sub-index DO, and $\mathrm{SI}_{\mathrm{Con}}=$ Subindex conductivity [73].

\subsubsection{Universal Water Quality Index (UWQI)}

The UWQI was developed by Boyacioglu on the basis of water quality standards set by the Council of the European CommunitiesA, the Turkish water pollution control regulations and other scientific information to select 12 water-quality parameters as the most representative for drinking water quality. Water quality determinants of the new index are cadmium, cyanide, mercury, selenium, arsenic, fluoride, nitrate-nitrogen, dissolved oxygen, biochemical oxygen demand, total phosphorus, $\mathrm{pH}$ and total coliform. To assign weights to the water-quality variables the following factors are taken into account:

- Chemical parameters had a lower weight than microbiological parameters, because microbial contaminants belong to the greatest health impact category.

- Higher weight was given to those parameters which are of known health concern.

The temporary weights ranged from 1 to 4 on a basic scale of importance. On this scale 1, 2, 3 and 4 denote respectively 
little, average, great and very great importance. Each weight was then divided by the sum of all weights to arrive at the final weight factor. The index is given by:

$$
U W Q I=\sum_{i=1}^{n} W_{i} I_{i},
$$

where $W_{i}$ is the weight for ith parameter and $I_{i}$ is the subindex for ith parameter.

Water quality can be ranked as poor (0-24), marginal (25-49), fair (50-74), good (75-94), or excellent (95-100), according to the UWQI scale [74-75].

\subsubsection{Fuzzy Water Quality Index(FQWI)}

Fuzzy Expert System is a rule based expert system where fuzzy logic is used as a tool for representing different form of knowledge about the problem. The proposed system consists of 5 input, 1 output and 10 rules Here FWQI based on five input parameter. System output is actually giving the drinking water quality which is divided into four types. The knowledge base describing the system's behavior is represented by the membership functions designing the linguistic variables. Hence, for the proposed system's behavior, six linguistic variables are defined. Out of these six, five is input variables namelyturbidity (T), dissolved oxygen (DO), biochemical oxygen demand (BOD), $\mathrm{pH}$ value ( $\mathrm{pH}$ ), and Fecal Coli form (FC) and one is output variable drinking water quality. fuzzyfier unit computes the membership values of each input variable in accordance with the fuzzy values defined in the database. Inference engine interprets the rules combined in the rule base. The Inference engine is performed in three steps, (1) antecedent 
establishment (2) implication (3) aggregation. Finally, defuzzification convert the fuzzy output into cripes value. Water quality is determined by its physical, chemical, and bacteriological characteristics and in order to evaluate quality of water. The parameters measured for analysis are turbidity $(\mathrm{T})$, dissolved oxygen (DO), biochemical oxygen demand (BOC), $\mathrm{pH}$ value $(\mathrm{pH})$, and Fecal Coli form (FC) Input Parameters Turbidity (T)- Turbidity is categorized into three fuzzy sets with membership functions as follows: (1) Good (G): 0-5NTU, (2) Little bit good (LG): 3-8NTU, (3) Poor (P): 7-10NTU. Dissolved Oxygen (DO) - DO is categorized into four fuzzy sets and their membership functions are given below: (1) Low (L): 0-4 mg/L, (2) Moderate (M): 2-6 mg/L, (3) High (H): 5-9 $\mathrm{mg} / \mathrm{L}$, (4) Very high (VH): 7-10mg/L. Biochemical Oxygen Dissolved $\left(\mathrm{BOD}_{5}\right)-\mathrm{BOD}_{5}$ is categorized into four fuzzy sets and their membership functions are given below: (1) Low (L): 0-3 mg/L, (2) High (H): 2-6 mg/L, (3) V. High (VH): 5-10 $\mathrm{mg} / \mathrm{L}, \mathrm{pH}$ Factor $(\mathrm{pH})$. The $\mathrm{pH}$ factor is categorized into three fuzzy sets and their membership functions are given below: (1) Acidic (A): 0-6 (2) Desirable (D): 6-9 (3) Basic (B): 8-10 Fecal Coli form (FC) - FC is categorized into four fuzzy sets and their membership functions are given below: (1) Good (G) : 5000. Output variable is quality of drinking water. There are three classes of drinking water quality and the range for membership function is from 0 to 10. (1)Good for drinking water: 7-10 (2) Good for drinking water after treatment: 5-7 (3) Not good for drinking water: 0-5. A triangular and trapezoid membership function is used that determines how each point in the input space is mapped to a membership value between 0 and 1 [76]. 


\subsubsection{Weighted Arithmetic Water Quality Index Method}

Weighted arithmetic water quality index method classified the water quality according to the degree of purity by using the most commonly measured water quality variables [77]. The method has been widely used by the various scientists and the calculation of WQI was made by using the following equation:

$$
W Q I=Q_{i} W_{i} / W_{i} \text {. }
$$

Table 2.8.

Water Quality Rating as per Weight Arithmetic Water Quality Index Method.

\begin{tabular}{|c|c|c|}
\hline WQI Value & $\begin{array}{c}\text { Rating of Water } \\
\text { Quality }\end{array}$ & Grading \\
\hline $91-100$ & Excellent water quality & 1 \\
\hline $71-90$ & Good water quality & 2 \\
\hline $51-70$ & Medium water quality & 3 \\
\hline $26-50$ & Bad water quality & 4 \\
\hline $0-25$ & Very bad water quality & 5 \\
\hline
\end{tabular}

The quality rating scale $\left(\mathrm{Q}_{\mathrm{i}}\right)$ for each parameter is calculated by using this expression:

$$
W_{i}=100\left[\left(V_{i}-V_{0} / S_{i}-V_{0}\right)\right],
$$

where, $V_{i}$ is estimated concentration of ith parameter in the analysed water,

$V_{o}$ is the ideal value of this parameter in pure water, $V_{o}=0$ (except $\mathrm{pH}=7.0$ and $\mathrm{DO}=14.6 \mathrm{mg} / \mathrm{l}$ ) is recommended standard value of ith parameter The unit weight (Wi) for each water quality parameter is calculated by using the following formula:

$$
W_{i}=K / S_{i},
$$


where, $\mathrm{K}$ is proportionality constant and can also be calculated by using the following equation [77]:

$$
\mathrm{K}=\frac{1}{\Sigma\left(1 / s_{i}\right)} \text {. }
$$

\subsubsection{Water Contamination Index (WCI)}

WCI is established by the USSR Goskomgidromet and belongs to the category of indicators most often used to assess the quality of water bodies. This index is a typical additive coefficient and represents the average percentage of exceeding the MAC for a strictly limited number of individual ingredients [78]:

$$
W C I=\frac{1}{n} \sum_{i=1}^{n} \frac{C_{i}}{M A C_{i}},
$$

where: $\boldsymbol{C}_{\boldsymbol{i}}$ - concentration of the component (in some cases - the value of the physicochemical parameter); $\boldsymbol{n}$ is the number of indicators used to calculate the index, $\boldsymbol{n}=6(\mathrm{pH}$, biological oxygen demand of $\mathrm{BOD}_{5}$ dissolved oxygen in water, $\mathrm{BOD}_{5}$, petroleum products, nitrite ions $\left(\mathrm{NO}_{2}^{-}\right)$, and ammonium ion $\left.\left(\mathrm{NH}_{4}^{+}\right)\right) . \mathrm{MAC}_{\mathbf{i}}$ - the established value of the standard for the relevant type of water body. To calculate the water pollution index for the entire set of standardized components, including the $\mathrm{pH}$-value, the biological oxygen demand of $\mathrm{BOD}_{5}$ and the dissolved oxygen content, the $\boldsymbol{C}_{\boldsymbol{i}} / \mathrm{MAC}$ ratios of the actual concentrations are found to be the MAC and the obtained list is sorted. The WCI is calculated strictly according to six indicators having the highest values of the given concentrations, regardless of whether they exceed the MAC or not. When calculating the 
IZV for the components $C_{i} / \mathrm{MAC}_{I}$, the following conditions apply unambiguously to the normed components:

- for biological oxygen consumption $\mathrm{BOD}_{5}$ (maximum permissible concentration - $3 \mathrm{mg} \mathrm{O}_{2} / \mathrm{dm}^{3}$ for water bodies for domestic and drinking water use and not more than $6 \mathrm{mg} \mathrm{O}_{2} / \mathrm{dm}^{3}$ for water bodies for domestic and cultural water use), special values of standards are established, depending on the very value of $\mathrm{BOD}_{5}$ :

$\mathrm{BOD}_{5}\left(\mathrm{mgO}_{2} / \mathrm{dm}^{3}\right)$

The value of the standard (MAC)

Less than 3

3 to 15

More than 15

- the concentration of dissolved oxygen is normalized to the exact opposite: its content in the sample should not be less than $4 \mathrm{mg} / \mathrm{dm}^{3}$, therefore for each range of concentrations of the component, special values of the terms $C_{\mathrm{i}} / \mathrm{MAC}_{i \text { are set. }}$

Table 2.9.

Correlation between concentrations of $\mathrm{DO}$ and $C_{\mathrm{i}} / \mathrm{MAC}_{i}$.

\begin{tabular}{|l|l|}
\hline Concentration $\left(\mathbf{m g O}_{2} / \mathbf{d m}^{3}\right)$ & The value of the term $\boldsymbol{C}_{\boldsymbol{i}} / \mathbf{M A C}_{\boldsymbol{i}}$ \\
\hline Greater than or equal to 6 & 6th \\
\hline Less than 6 to 5 & 12 \\
\hline Less than 5 to 4 & 20 \\
\hline Less than 4 to 3 & 30 \\
\hline Less than 3 to 2 & 40 \\
\hline Less than 2 to 1 & 50 \\
\hline Less than 1 & 60 \\
\hline
\end{tabular}


- For the $\mathrm{pH}$-value of $\mathrm{pH}$, the current standards for water in reservoirs for various purposes regulate the range of permissible values in the range from 6.5 to 8.5 , therefore, for any excess $\mathrm{pH}$ exceeding the limits of this range, special values of the $\boldsymbol{C}_{\mathrm{i}} /$.

Table 2.10.

Correlation between concentrations of $\mathrm{pH}$ and $C_{\mathrm{i}} / \mathrm{MAC}_{i}$.

\begin{tabular}{|l|l|l|}
\hline $\begin{array}{c}\text { The pH value is below the } \\
\text { normal range }(<\mathbf{6 . 5})\end{array}$ & $\begin{array}{c}\text { pH above normal } \\
\text { range }(>\mathbf{8 . 5})\end{array}$ & $\begin{array}{c}\text { The value of the } \\
\text { summand } \boldsymbol{C}_{\boldsymbol{i}} / \mathbf{M A C}_{\boldsymbol{i}}\end{array}$ \\
\hline Less than 6.5 to 6 & Over 8.5 to 9 & 2 \\
\hline Less than 3 to 5 & More than 9 to 9.5 & 5 \\
\hline Less than 5 & More than 9.5 & 20 \\
\hline
\end{tabular}

Depending on the magnitude of the IWW, water body sites are divided into classes (Table 2.11). It is required that water pollution indices be compared for water bodies of one biogeochemical province and of a similar type for the same watercourse (with the flow, in time, etc.) and also taking into account the actual water availability of the current year [78].

Table 2.11.

Classes of water quality depending on the value of the WCI

\begin{tabular}{|c|c|c|}
\hline WCI Value & Rating of Water Quality & Water quality classes \\
\hline up to 0,2 & Very clean & I \\
\hline $0.2-1.0$ & Clean & II \\
\hline $1.0-2.0$ & Moderately polluted & III \\
\hline $2.0-4.0$ & Contaminated & IV \\
\hline $4.0-6.0$ & Dirty & V \\
\hline $6.0-10.0$ & Very dirty & VI \\
\hline$>10.0$ & Extremely dirty & VII \\
\hline
\end{tabular}




\subsubsection{Specific Combinatory Water Quality Index (SCWQI)}

In accordance with RD 52.24.643-2002, "The method for the integrated assessment of the degree of contamination of surface waters by hydrochemical indicators" introduced the calculation of the specific combinatorial water quality indexs index. To assess the quality of water in rivers and water bodies, they are divided by contamination into several classes. The classes are based on the intervals of the specific combinatory water pollution index, depending on the number of critical pollution indicators. At least 15 indicators are analyzed. Required list: dissolved oxygen in water, $\mathrm{BOD}_{5}$, chemical oxygen consumption - COD, phenols, petroleum products, nitrite ions $\left(\mathrm{NO}_{2}^{-}\right)$, nitrate ions $\left(\mathrm{NO}_{3}^{-}\right)$ammonium ion $\left(\mathrm{NH}_{4}^{+}\right)$, iron total $\left(\mathrm{Fe}^{2+}\right.$ and $\left.\mathrm{Fe}^{3+}\right)$, copper $\left(\mathrm{Cu}^{2+}\right)$, zinc $\left(\mathrm{Zn}^{2+}\right)$, nickel $\left(\mathrm{Ni}^{2+}\right)$, manganese $\left(\mathrm{Mn}^{2+}\right)$, chlorides and sulphates

2 stage. Preliminary assessment of contamination with using the coefficient of complexity of water pollution (K), which is the ratio of the number pollutants, the content of which exceeds the MAC, to the total number taken into account in the calculation of substances [79]:

$$
K=\frac{n^{*}}{n} 100 \%,
$$

where $n *$ is the number of ingredients and quality indicators, the content which exceeds the established MAC; $\mathrm{n}$ is the total number standardized ingredients and quality indicators. The coefficient of complexity $\mathrm{K}$ characterizes in mainly the participation of the anthropogenic component in the formation of the chemical composition of water in water bodies. Than 
more $\mathrm{K}$, the worse the quality of water and the greater the impact on the formation of quality has an anthropogenic factor. This coefficient is measured in percent, the range its changes are $1-100 \%$. If the value is $\mathrm{K} \geq 10 \%$, apply method of integrated water quality assessment. At $\mathrm{K}<10 \%$ water contamination is caused by single components and a detailed differentiated examination is carried out.

3. stage. Relative assessment of water quality to the studied ingredient. At this stage, the frequency of cases is determined excess of standards. Repeatability of contamination cases aij, i.e. frequency detection of concentrations exceeding the MAC:

$$
\alpha_{i j}=\frac{n_{i j}}{n_{i j}} 100 \%,
$$

where $\mathrm{n}_{\mathrm{ij}}^{\prime}$ is the number of analysis results for the $\mathrm{i}$-th ingredient in the $\mathrm{h}$ jt during the considered period of time, in which the content or value exceeds the corresponding MAC; $\mathrm{n}_{\mathrm{ij}}$ is the total number of chemical analysis results for the period of time for the $\mathrm{i}$-th ingredient in the jth alignment. By the value of the frequency of occurrence of excess norms $\left(\alpha_{\mathrm{ij}}\right)$ and classification of water on this basis a separate scoring score is calculated for the repeatability of Saij, the value of which can vary from 1 to 4 . This procedure -The first stage of classification of water pollution. In addition to the repeatability, the mean value multiplication of MAC excess by the results of samples, where such the excess was observed $\left(\beta_{\mathrm{ij}}\right)$.

$$
\bar{\beta}_{i j}^{\prime}=\frac{\sum_{i j}^{n} \beta_{i f j}}{n_{i j}^{\prime}},
$$


where $\beta_{i j}=\frac{C_{i j}}{M A C}$ is the multiplicity of exceeding the MAC by $\mathrm{i}$ ingredient in the fth result of the chemical analysis for the jth alignment; Determination of the rate of violation of the standard for dissolved in water oxygen is carried out according to the formula: Calculation of the average value of the multiplicity of excess MAC is carried out according to the formula:

$$
\beta_{O_{2}}=\frac{M A C_{O_{2}}}{C_{O_{2}}}
$$

where $\mathrm{C}_{\mathrm{O} 2 \mathrm{fj}}$ is the concentration of dissolved oxygen in $\mathrm{f}-\mathrm{m}$ result of chemical analysis for the $\mathrm{j}$-th line, $\mathrm{mg} / \mathrm{dm}^{3}$. By the value of the average multiplicity of excess MAC $\left(\beta_{\mathrm{ij}}\right)$ and the classification of water according to this characteristic is calculated a partial scoring score for $\left(\beta_{\mathrm{ij}}\right)$, which can vary from 1 to 4 . This procedure is the second stage of classification water pollution.

Further, in the fourth stage, a generalized the score $\left(S_{i j}\right)$ as the product ofpoints on the frequency and multiplicity that can vary from 1 to 16 .

5 stage. Calculation of combinatorial index and specific combinatorial index of water pollution. Combinatory water pollution index is determined as the sum of the generalized scores $\left(\mathrm{S}_{\mathrm{ij}}\right)$ according to the following formula:

$$
S_{j}=\sum_{i=1}^{N_{j}} S_{i j},
$$

where $S_{j}$ is the combinatorial water pollution index in the jth alignment; $\mathrm{N}_{\mathrm{j}}$ is the number of ingredients considered in the evaluation.

Specific combinatorial index of water pollution is determined by the following formula: 


$$
S C W Q I=\frac{S_{j}}{N_{j}},
$$

where $S_{j}$ - combinatorial index of water pollution in $j$-th alignment; $\mathrm{N}_{\mathrm{j}}$ is the number of ingredients considered in the evaluation. Specific combinatorial index of water pollution It is also used to estimate the level of contamination and is a very convenient and indicative characteristic. Him use is mandatory if the calculations were made in different ways number of ingredients.

Stage 6. Classification of water quality by degree contamination. Classification of water quality by degree contamination is carried out taking into account the following data: combinatorial index of water pollution, the number of water storage tanks (see the text above), the safety factor, the number of evaluation of ingredients and pollution indicators. The safety factor $\mathrm{k}$ is calculated by the formula:

$$
\mathrm{k}=1-0.1 \mathrm{~F}(3.61) \text {, }
$$

where $\mathrm{F}$ is the number of critical indicators of water pollution. The safety factor $\mathrm{k}$ is introduced further in graduation water quality classes in addition to combinatorial index of water pollution to tighten the assessment in the case of detection of concentrations close to or reaching levels high or extremely high pollution. Its meaning decreases with increasing number of bullpen: from unity at The absence of a bullpen to 0.9 at one bullpen, etc. Coefficient The reserve is calculated at $\mathrm{F} \leq 5$. 
Table 2.12.

Surface water quality categories.

\begin{tabular}{|c|c|c|c|c|c|c|c|}
\hline \multirow{3}{*}{$\begin{array}{l}\text { Class and } \\
\text { rank }\end{array}$} & \multirow{3}{*}{$\begin{array}{l}\text { Characteristics } \\
\text { of the state of } \\
\text { water pollution }\end{array}$} & \multicolumn{6}{|c|}{ Specific combinatorial index of water pollution } \\
\hline & & \multirow{2}{*}{\begin{tabular}{|c|}
$\begin{array}{c}\text { without } \\
\text { regard to } \\
\text { the }\end{array}$ \\
number \\
of bullpen
\end{tabular}} & \multicolumn{5}{|c|}{$\begin{array}{l}\text { depending on the number of } \\
\text { accountable bullpen }\end{array}$} \\
\hline & & & 1 & 2 & 3 & 4 & 5 \\
\hline $1 \mathrm{st}$ & $\begin{array}{l}\text { Conditionally } \\
\text { pure }\end{array}$ & 1 & 0.9 & 0.8 & 0.7 & 0.6 & 0.5 \\
\hline 2 nd & $\begin{array}{l}\text { Slightly } \\
\text { contaminated }\end{array}$ & 12 & $\begin{array}{c}0.9- \\
1.8\end{array}$ & $\begin{array}{c}0.8- \\
1.6\end{array}$ & $\begin{array}{c}0.7- \\
1.4\end{array}$ & $\begin{array}{c}0.6- \\
1.2\end{array}$ & $\begin{array}{c}0.5- \\
1.0\end{array}$ \\
\hline $3 \mathrm{rd}$ & Contaminated & $2-4$ & $\begin{array}{c}1.8- \\
3.6\end{array}$ & $1.6-3.2$ & $1.4-2.8$ & $\begin{array}{c}1,2- \\
2,4\end{array}$ & $\begin{array}{c}1.0- \\
2.0\end{array}$ \\
\hline $\begin{array}{l}\text { discharge } \\
\text { "a" }\end{array}$ & Contaminated & $2-3$ & $1.8-2.7$ & $1.6-2.4$ & $1.4-2.1$ & $\begin{array}{c}1,2- \\
1,8\end{array}$ & $\begin{array}{c}1.0- \\
1.5\end{array}$ \\
\hline Rank "b" & Very polluted & $3-4$ & $\begin{array}{c}2.7- \\
3.6\end{array}$ & $2.4-3.2$ & $\begin{array}{c}2.1- \\
2.8\end{array}$ & $\begin{array}{c}1.8- \\
2.4 \\
\end{array}$ & $1.5-2.0$ \\
\hline 4 th & Dirty & $4-11$ & $\begin{array}{c}3.6- \\
9.9\end{array}$ & $3.2-8.8$ & $\begin{array}{c}2.8- \\
7.7\end{array}$ & $\begin{array}{c}2.4- \\
6.6\end{array}$ & $2.0-5.5$ \\
\hline $\begin{array}{l}\text { discharge } \\
\text { "a" } \\
\end{array}$ & Dirty & $4-6$ & $\begin{array}{c}3.6- \\
5.4 \\
\end{array}$ & $3.2-4.8$ & $\begin{array}{c}2.8- \\
4.2 \\
\end{array}$ & $2.4-3.6$ & $\begin{array}{c}2.0- \\
3.0 \\
\end{array}$ \\
\hline Rank "b" & Dirty & $6-8$ & $\begin{array}{c}5.4- \\
7.2\end{array}$ & $\begin{array}{c}4.8- \\
6.4\end{array}$ & $4.2-5.6$ & $\begin{array}{c}3.6- \\
4.8\end{array}$ & $\begin{array}{c}3.0- \\
4.0\end{array}$ \\
\hline Rank "B" & Very dirty & $8-10$ & $\begin{array}{c}7.2- \\
9.0\end{array}$ & $\begin{array}{c}6.4- \\
8.0\end{array}$ & $\begin{array}{c}5.6- \\
7.0\end{array}$ & $\begin{array}{c}4.8- \\
6.0\end{array}$ & $\begin{array}{c}4.0- \\
5.0\end{array}$ \\
\hline Grade "g" & Very dirty & $8-11$ & $\begin{array}{c}9.0- \\
9.9 \\
\end{array}$ & $\begin{array}{c}8.0- \\
8.8 \\
\end{array}$ & $\begin{array}{c}7.0- \\
7.7\end{array}$ & $\begin{array}{c}6.0- \\
6.6 \\
\end{array}$ & $5.0-5.5$ \\
\hline 5 th & Extremely dirty & $\begin{array}{l}11 \text { and } \\
\text { more }\end{array}$ & $\begin{array}{c}9.9 \text { and } \\
\text { more }\end{array}$ & $\begin{array}{c}8,8 \\
\text { and } \\
\text { more }\end{array}$ & $\begin{array}{c}7.7 \\
\text { and } \\
\text { more }\end{array}$ & \begin{tabular}{|c}
6.6 \\
and \\
more
\end{tabular} & \begin{tabular}{|c|}
5,5 \\
and \\
more
\end{tabular} \\
\hline
\end{tabular}


The definition of water quality classes is based on the product of these values and the subsequent the grading of the class corresponding to it classification. The value of the SWQI is determined by the frequency and the multiplicity of the MAC exceeding by several indicators and can vary in waters of different degree of contamination from 1 to 16 (for pure water 0 ). The higher the index value corresponds to the worst water quality. taking into account the number of bullpen, allows you to divide the surface waters into 5 classes, depending on the degree of their contamination. The 3rd and 4th classes for a more detailed water quality assessment are divided into 2 and 4 categories respectively. The classification of water quality is given in Table $2.12[6,79]$.

\subsubsection{The Model of Flow Transferring Substance's Quantity Index (FTSQI)}

Nowadays, hydrochemical assessment of rivers is based on integrated methods, which can uniquely determine the status of water body, the level of water pollution and its change due to anthropogenic impact, given the wide range of contaminants. Frequently, as the general tool for expressing integrated assessment result of water pollution of waterbody is water quality index (WQI). WQIs have different structure, the list of accounted hydro parameters and unique assessment mechanism of water pollution depending on the purpose of water consumption. All kinds of WQIs directed to sum up the main hydrochemical, biological and/or hydrological data in a single integrated unit, through which it becomes possible to classify 
water body by pollution level. The calculation of WQI is based on logarithmic modifications of each hydrochemical or biological or hydrological parameter data through a set of mathematical equations, which also include maximum available concentration and background concentration for the parameter. Only a few amount of these WQI can integrate both hydrochemical and hydrological data at the same time [6].

In order to combine the hydrological and hydrochemical parameters for integrated assessment of water resources changes as a result of climatic changes of the region, it was suggested new model - Index of Transfer Quantity of Substance by River Flow (ITQSRF). Through ITQSRF it is possible to calculate annual or monthly quantity of transferring substance by river flow. Also, it is allowed for long-term calculation dynamics, usually per five years.

The model has wide spectrum using of transferring hydrochemical parameters calculation, such as mineralization, heavy metals, hardness, total nitrogen, phosphorus and etc. For annual transferring of the substance, it is calculated as follow:

$$
I T Q S R F=31.536 \cdot \sum_{i=1}^{n} W_{i} \overline{C_{i}},
$$

where $\mathrm{W}_{\mathrm{i}}$ is the river water flow during i time period $\left(\mathrm{m}^{3} / \mathrm{sec}\right)$; $\mathrm{C}_{\mathrm{i}}$ is average concentration of the hydrochemical parameter during i time period $\left(\mathrm{mg} / \mathrm{dm}^{3}\right)$, ITQSRF's unit is tons by year. For monthly calculation it becomes:

$$
I T Q S R F=2.592 \cdot \sum_{i=1}^{n} W_{i} \overline{C_{i}}
$$


In this case ITQSRF's unit is tons by month. If there are no any data about concentration of the hydrochemical parameter (or hydrological data of river), the Index value can be calculated as comparison with analog river transferring amount of the same substance. It could be as follow:

$$
I T Q S R F=\frac{I T Q S R F_{a} \cdot W}{W_{a}},
$$

where $\mathrm{W}$ is the river water flow of the study river and $\mathrm{W}_{\mathrm{a}}-$ for analog river $\left(\mathrm{m}^{3} / \mathrm{sec}\right)$; ITQSRF $\mathrm{I}_{\mathrm{a}}$ is calculated for analog river.

The analog-river is the river comparable or semi-comparable discharge and geochemical region of flow with the study river. This kind of ITQSRF's determination is indicative, and it could become more accuracy if the analog-river will be chosen not only as comparable with river flow, but also comparable with hydrochemical content. The ITQSRF has also another component, which is anthropogenic contribution of transferring amount of the substance. The idea of the anthropogenic component is to reduce from total transferring amount of substances its background part. This anthropogenic component is calculated as follow:

$$
\mathrm{ITQSRF}_{\mathrm{a}}=\mathrm{ITQSRF}_{\mathrm{p}}-\mathrm{K}_{\mathrm{B}} \cdot \mathrm{ITQSRF}_{\mathrm{f}},
$$

where ITQSRF $F_{a}$ is the anthropogenic component of transferring amount of substance given for relevant period, ITQSRF $\mathrm{F}_{\mathrm{p}}$ is the total amount of transferring amount of substance given for relevant period, $\mathrm{ITQSRF}_{\mathrm{f}}$ is the background amount of transferring substance, $\mathrm{K}_{\mathrm{B}}$ - correction factor for the difference of water flow during the study and background periods. 
The background period, in this case, is determined as the time, when were absent any antropogenic influence on river's hydrochemical regime or their impact was uncertainty. Mostly, that time period is considered up to 1980, because of the human impact on natural water resources was extremely increased in the coming years. The relative error of calculation of ITQSRF for (2.33) and (2.34) is determined according to assumptions of the theory of errors.

It will be:

$$
S_{C_{i}}=\sqrt{S_{W_{i}}^{2}+S_{K_{i}}^{2}}
$$

where $S_{\mathrm{Ci}}$ is the relative error for ITQSRF calculation for i time period, $\mathrm{S}_{\mathrm{Wi}_{\mathrm{i}}}$ - the relative error of determination of river flow for $i$ time period, $S_{\mathrm{Ki}}-$ the relative error of determination of average concentration of transferring substance for i time period.

The relative error for determination of river flow $\left(\mathrm{S}_{\mathrm{Wi}}\right)$ is approximately $10 \%$, in the case of determination method was defined as "velocity-area" with using of hydrological turntables, which was the mostly used method in practice. The relative error of determination of average concentration of transferring substance is calculated as follow:

$$
S_{K_{i}}=\frac{1}{\bar{C}} \sqrt{\frac{\sigma_{B}^{2}+\left(\bar{C} \cdot v_{a}\right)^{2}}{n}},
$$

where $\sigma_{B}^{2}$ - standard deviation of the time series of the average concentrations in the river section; $\mathrm{C}$ - the average concentration of transferring substance for i time period, $v_{a}-$ relative error of the method of analysis, $\mathrm{n}-$ the number of water samples for $\mathrm{i}$ time period. 
Summarizing, absolute error $\left(\triangle \mathrm{ITQSRF}_{\mathrm{i}}\right)$ for ITQSRF calculation for i time period will be:

$$
\Delta \mathrm{ITQSRF}_{\mathrm{i}}= \pm \mathrm{ITQSRF}_{\mathrm{i}} \cdot \mathrm{S}_{\mathrm{G}_{\mathrm{i}}},
$$

The suggested by authors the new model (ITQSRF) also has computer based calculation annexe in MsExcel program. The created annexe automatically calculates $(2.33,2.36,2.37,2.38$, 2.39) equations after inputting all necessary data of river (river flow, concentration ranges of transferring substances, relative error of the method of analysis, and etc.) [6].

\subsection{Examples of the Rivers' water quality assessment}

Hydrochemical Measures: Hydrochemical observation of Hrazdan River was performed in both sampling points for general ions, Mineralization, Total Hardness, $\mathrm{BOD}_{5}$ and Dissolved oxygen. Water sampling was carried out for almost all months of a year during 1983-2013, according to ISO 56671:2006 international standards. The mineralization of river water was assessed as the sum of general ions (calcium, manganese, potassium, sodium, sulphate, chloride, bicarbonate). The total hardness of water was assessed as the sum of calcium and manganese equivalents amount. Concentrations of calcium, manganese, potassium and sodium were determined by ICPmass spectrometric methods on ISO 17294-2:2005 via Elan 9000 device.

Concentrations of sulphate and chloride were determined by ion-chromatography method on ISO 10304-1:2007 via Dionex 1000 device. Concentrations of bicarbonate in water samples 
were measured by Turbidimetric method on GOST 20806228:069(02)-77. The dissolved oxygen was measured by ISO 5814:1990 (E) via WTW 320i multi parameter device [80-85].

Hydrological Measures: Hydrological observations of Hrazdan River were performed in Hrazdan-Hrazdan sampling point by meteorological station of Armenian State Hydro-Meteorological Service SNCO during 1983-2013. The river flow was assessed by "velocity-area" with using of hydrological turntables methods [86].

\subsubsection{Hrazdan River}

The objective of the current task is to focus on the Hrazdan River, which is one of the major rivers of Armenia, the river bed of which flows through the center of territory of the republic [42].

Selection of the Hrazdan River is based on the following principles and criteria:

- availability of data time series for systematic meteorological observations and availability of all major hydrological and hydrochemical data;

- importance of the river water for agriculture. Hrazdan River is one of the major rivers in Armenia, which has significant role for agriculture. The lower flow of the river water irrigates the Ararat valley.

Sampling points for the Hrazdan River are located: №51near Geghamavan village, $13 \mathrm{~km}$ above Hrazdan city, № 52- 0.5 $\mathrm{km}$ below the village of Kaghsi, № 53- $0.5 \mathrm{~km}$ below Argel 
village, №54- $0.5 \mathrm{~km}$ below Arzni HPP, №55- near Darbnik village, $6 \mathrm{~km}$ below the Yerevan city, №56- near the river mouth [14].

Hydrology: Hrazdan River originates from the largest freshwater lake in the Caucasus region, Lake Sevan, at about $1900 \mathrm{~m}$ above the sea level. The head water of the Hrazdan River is an artificially dug canal. In Sevan city the canal flows into a $5 \mathrm{~km}$ long underground tunnel and in Geghamavan village flows into the surface passing. The river flows into Araks River. The river's length is $141 \mathrm{~km}$ and its catchment area is 2650 sq.km. The annual mean discharge of the river is $22.6 \mathrm{~m}^{3} / \mathrm{sec}$, maximum discharge $-138 \mathrm{~m}^{3} / \mathrm{sec}$. and the minimum discharge $9 \mathrm{~m}^{3} / \mathrm{sec}$, the annual flow is $712 \mathrm{mln} . \mathrm{m}^{3}$. The river's largest tributary is Marmark River. Hrazdan River feeds by melting snow (55\%), rain (18\%) and groundwater $(62.5 \%)$. The River's water is mainly used for irrigation, hydro energy, municipal and sanitary service and industrial purposes.

Starting from Lake Sevan and flowing through major cities and villages, the River Hrazdan is one of the most polluted rivers in the country. The upper streams of the river, as well as the downtown Yerevan suburb, are mainly polluted with economic, communal-household wastewater of the settlements, inorganic and organic fertilizers, pesticides and pesticides used for agricultural purposes, wastewater of livestock farms, etc.

Passing through the territory of Yerevan (capital city of Armenia), the Hrazdan River, due to inadequate operation of the "Aeratsia" wastewater treatment plant, besides the city municipal waste water, is also polluted with synthetic rubber, polymeric materials and plastics, tires and rubber technical 
items, synthetic corundum and synthetic filaments, varnishes, paints, laundry, chemical reagents, nitrogen fertilizers, cyanamide and other materials, as a result of construction works carried out on the bank of the river it is polluted with building materials, while crossing the City of Yerevan, it is also polluted by wastewater of the restaurant complex, solid waste, which often has discharged directly into the river without treatment.

The river discharge of the river at №55 sampling point is the point of observation under the influence of a high anthropogenic load. Point of observation №55 is located near the "Aeratsia" WWT plant in Yerevan, where municipal and domestic wastewater is discharged from small industrial enterprises. Considering that the plant "Aeratsia" of the city does not work at full capacity and performs only mechanical cleaning, it can be assumed that sewage is discharged into the river almost uncleaned.

From the observation point №55 to the river mouth, the anthropogenic load on the river is significantly reduced, but bearing in mind that this part of the river flows through densely populated areas (most small villages) and passes through irrigated fields, its complete elimination is not possible [42].

Assessment of Hrazdan River Water Quality using WQOI method. The water quality in the Hrazdan River during 2008-2012 is corresponding to 4th (poor) and 5th (bad), and in the lower streams of the Hrazdan River, water is corresponded to the 5 th water quality class. 
Table 2.13

Water Pollution level of Hrazdan River for 2008-2012 determined by WQOI.

\begin{tabular}{|c|c|c|c|c|c|c|c|c|c|c|}
\hline $\begin{array}{c}\text { Sampling } \\
\text { points }\end{array}$ & \multicolumn{2}{|c|}{2008} & \multicolumn{2}{c|}{2009} & \multicolumn{2}{c|}{2010} & \multicolumn{2}{c|}{2011} & \multicolumn{2}{c|}{2012} \\
\hline 51 & 26.60 & 5cll. & 65.69 & 4cll. & 26.73 & 5 cll. & 74.81 & 4cll. & 26.53 & 5cll. \\
\hline 52 & 72.78 & 4cll. & 69.53 & 4cll. & 69.93 & 4cll. & 68.25 & 4cll. & 58.60 & 5cll. \\
\hline 53 & 68.22 & 4cll. & 66.80 & 4cll. & 64.10 & 4cll. & 62.51 & 4cll. & 52.83 & 5cll. \\
\hline 54 & 69.80 & 4cll. & 59.95 & 5cll. & 25.18 & 5cll. & 25.79 & 5cll. & 60.46 & 4cll. \\
\hline 55 & 15.48 & 5cll. & 15.83 & 5cll. & 15.83 & 5cll. & 14.01 & 5cll. & 14.02 & 5cll. \\
\hline 56 & 15.98 & 5 cll. & 16.00 & 5cll. & 16.07 & 5cll. & 18.99 & 5 cll. & 18.94 & 5cll. \\
\hline
\end{tabular}

Getting out of Lake Sevan, the Hrazdan River water, according to WQOI values, belongs to the 4th (poor), and in separate years, through the third (moderate), by passing through large and small settlements, to the lake in Yerevan, the river's water is predominantly 4th (5th WQ class in separate years) poor water quality class. There is no difference between the values of the WQOI, which flows down the river up to the Yerevan Lake.

Crossing the city of Yerevan, Hrazdan River water is exposed to strong anthropogenic load, as a result of which the WQOI does not exceed the value of 19.4, the annual change is not observed and the water belongs to the 5th grade, with extraordinary dirty quality.

Assessment of Hrazdan River Water Quality using WQMI method. According to long-term monitoring data of the Hrazdan River, the quality of water is according to 2nd class (good), downstream from the Hrazdan River Yerevan and the 
third part of the riverbed (moderate), and in some years in the 4th (poor) class.

The water of the WQMI values in the upper streams of the Hrazdan River is the second (poorly polluted) order and does not expire annually and down the river. Water in these sections of the river is suitable for water supply, recreation, fisheries and irrigation purposes.

Table 2.14

Water Pollution level of Hrazdan River for 2008-2012 determined by WQMI.

\begin{tabular}{|c|c|c|c|c|c|c|c|c|c|c|}
\hline $\begin{array}{c}\text { Sampling } \\
\text { points }\end{array}$ & \multicolumn{2}{|c|}{2008} & \multicolumn{2}{c|}{2009} & \multicolumn{2}{c|}{2010} & \multicolumn{2}{c|}{2011} & \multicolumn{2}{c|}{2012} \\
\hline 51 & 80.61 & 2cll. & 87.11 & 2cll. & 79.93 & 2cll. & 85.20 & 2cll. & 81.33 & 2cll. \\
\hline 52 & 84.23 & 2cll. & 85.29 & 2cll. & 85.86 & 2cll. & 84.42 & 2cll. & 82.30 & 2cll. \\
\hline 53 & 85.94 & 2cll. & 87.17 & 2cll. & 85.26 & 2cll. & 85.28 & 2cll. & 84.93 & 2cll. \\
\hline 54 & 85.84 & 2cll. & 85.87 & 2cll. & 82.26 & 2cll. & 82.83 & 2cll. & 81.47 & 2cll. \\
\hline 55 & 59.50 & 3cll. & 68.85 & 3cll. & 68.83 & 3cll. & 63.15 & 3cll. & 56.66 & 3cll. \\
\hline 56 & 70.07 & 3 3cll. & 72.30 & 3cll. & 68.84 & 3cll. & 72.52 & 3cll. & 66.23 & 3cll. \\
\hline
\end{tabular}

As a result of industrial and economic activity of Yerevan city, WQMI values are within the limits of the 3rd and 4th categories in recent years downstream from Hrazdan River Yerevan and near the estuary. According to the WQMI values, the water is suitable for use in water, for recreational, fishery and irrigation purposes, and water can be used for irrigation only because of high pollution in the downstream city of Yerevan, and only some resistant fish can survive in the river. 


\subsubsection{Akhuryan River}

Sampling points for the Akhuryan River are located: №31$0.5 \mathrm{~km}$ above the city of Amasia, №32 - $1 \mathrm{~km}$ below the city of Amasia, №33- $0.8 \mathrm{~km}$ above the city of Gyumri, №34-5 km above the city of Gyumri [17].

Hydrology. Akhuryan River is one of the largest rivers in the Republic, beginning with the Arpilsh reservoir and flowing through the Shirak region. The Akhuryan River is quite abundant and irrigates the agricultural areas of the province. The Akhuryan River originates from the Arpilich Reservoir, located at the absolute altitude of $2,017 \mathrm{~m}$, and at $708 \mathrm{~km}$ from the river mouth flows into Araks River (at the altitude of $905 \mathrm{~m}$ ). The total length of the river is $186 \mathrm{~km}$. The largest tributaries of the Akhuryan River are: Karkachun, Tavshut, Ashotzq and Jradzor.

River flows along its flow in the territory of the Republic of Armenia are polluted mainly by communal-economic streams of adjacent settlements. In the upper streams Akhuryan River flows into many smaller villages, communities and towns. There are no water treatment plants in this area, which is why the utilityhousehold waste water in the settlements does not flow into the river immediately without polluting, contaminating it with various household waste.

Agriculture has also contributed to the pollution of the Akhuryan River. Passing through the agricultural land, the river is flooded with the surface flows formed by precipitation, which, as a result of soil leaching, contain various chlorotic pesticides, natats, phosphates, etc. 
The big anthropogenic river of the Akhuryan River also falls on the Gyumri city. The flow of utility-economic, smallscale industrial enterprises in the capital without flowing into the river is causing great damage to the river ecosystem [42].

Assessment of Akhuryan River Water Quality by WQOI method. According to the hydrochemical assessment results for Akhuryan River in 2008-2012 the WQOI values indicate that river water is corresponded to the 4th class, poor, and 5th class, bad water quality classes. The water quality in the upper and middle currents of the river has changed in proportion to years, diminishing up to "extreme contamination" or climbing to a maximum of 4th class of poor quality (Table 3 ).

Throughout the study, the water was characterized as a 5th class - extremely polluted quality in the downstream part of the Akhuryan River in Gyumri. According to the WQOI assessment or river water, the pollution was particularly high in 2008 and in 2012, when the water across the whole river was of the 5th class - an extremely polluted quality. The high values of WQOI indicate that there is always high pollution in the communal water of the river.

Table 2.15

Water Pollution level of Akhuryan River for 2008-2012

determined by WQOI.

\begin{tabular}{|c|c|c|c|c|c|c|c|c|c|c|}
\hline $\begin{array}{c}\text { Sampling } \\
\text { points }\end{array}$ & \multicolumn{2}{|c|}{2008} & \multicolumn{2}{|c|}{2009} & \multicolumn{2}{c|}{2010} & \multicolumn{2}{c|}{2011} & \multicolumn{2}{c|}{2012} \\
\hline 31 & 78.35 & 4cll. & 79.88 & 4cll. & 26.76 & 5cll. & 77.41 & 4cll. & 26.67 & 5cll. \\
\hline 32 & 75.73 & 4cll. & 73.62 & 4cll. & 76.24 & 4cll. & 76.06 & 4cll. & 26.66 & 5cll. \\
\hline 33 & 71.56 & 4cll. & 68.54 & 4cll. & 68.96 & 4cll. & 19.51 & 5cll. & 26.38 & 5cll. \\
\hline 34 & 25.24 & 5cll. & 19.56 & 5cll. & 16.12 & 5cll. & 16.11 & 5cll. & 16.06 & 5cll. \\
\hline
\end{tabular}


Assessment of Akhuryan River Water Quality by WQMI method. According to the study data in 2008-2012, water of the Akhuryan River is basically corresponded to the 2nd class - poorly polluted or good water quality class. In some areas of the river, the quality of the river water has been reduced to the 3rd class of polluted water in separate years.

The hydrochemical results obtained show that according to WQMI, the pollution of the Akhuryan River has increased since 2008.

Table 2.16

Water Pollution level of Akhuryan River for 2008-2012 determined by WQMI.

\begin{tabular}{|c|c|c|c|c|c|c|c|c|c|c|}
\hline $\begin{array}{c}\text { Sampling } \\
\text { points }\end{array}$ & \multicolumn{2}{|c|}{2008} & \multicolumn{2}{c|}{2009} & \multicolumn{2}{c|}{2010} & \multicolumn{2}{c|}{2011} & \multicolumn{2}{c|}{2012} \\
\hline 31 & 78.39 & 2 cll. & 86.41 & 2cll. & 83.76 & 2cll. & 83.80 & 2cll. & 75.85 & 3cll. \\
\hline 32 & 75.78 & 3 cll. & 84.84 & 2cll. & 83.64 & 2cll. & 84.30 & 2cll. & 79.27 & 2cll. \\
\hline 33 & 77.05 & 2cll. & 77.93 & 2cll. & 75.75 & 3cll. & 81.67 & 2cll. & 76.67 & 2cll. \\
\hline 34 & 68.60 & 3cll. & 70.13 & 3cll. & 69.97 & 3cll. & 69.66 & 3cll. & 67.51 & 3cll. \\
\hline
\end{tabular}

As a result of the active economic and construction activities of Gyumri, the river water is exposed to continuous anthropogenic load which has led to a decrease in water quality in this part of the river in recent years.

According to the WQMI estimation, Akhuryan River water is suitable for upper and middle currents, as well as for reclamation, fish breeding, irrigation, microbiological and weak chemical treatment for water supply. As a result of continuous contamination of upper and middle currents in the downstream part of the river Gyumri, water can become unusable for breeding sensitive fish species. 


\subsubsection{Sevdjur (Metsamor) River and its tributary Kasakh River}

Sampling points for the Sevdjur River are located: №40$10 \mathrm{~km}$ South of Vagharshapat town, №41 - 11km south-east of Vagharshapat town, №42- $0.5 \mathrm{~km}$ downstream Ranchpar village.

Sampling points for the Kasakh River are located: №43$00.5 \mathrm{~km}$ above the city of Aparan, №44 - $0.5 \mathrm{~km}$ below the city of Aparan, №45- $01 \mathrm{~km}$ above the city of Ashtarak, №46-3.5 km below the city of Ashtarak, and №47- at the mouth of the river [17].

Sevdjur and Kasakh rivers are the underground and surface water catchment where household, communal, economic waste water, small and medium-sized enterprises in small and medium-sized enterprises are inadequate and efficient under the conditions of the operation or absence of their municipal waste disposal facilities.

The Sevdjur River flows through the small ponds that are built for the swampy and fishery activities, subjected to various organic and biological contamination. Source of the Sevdjur River is wetlands located west of the Ayghr Lake, at the absolute altitude of $860 \mathrm{~m}$. At the same time, the Ayghr Lake has also a great role in feeding the river. The river flows through the Ararat Valley and discharges into Araks River at $625 \mathrm{~km}$ upstream the Araks River mouth. The total length of Sevdjur River, which has exclusively groundwater feeding, is $38 \mathrm{~km}$.

Sevdjur and Kasakh rivers are widely used in agriculture, livestock and fish farming, irrigation systems, and therefore 
polluted with various pesticides, toxic chemicals, inorganic and organic compounds of nitrogen and phosphorus.

The lower currents of the Kasagh River are also considered as holiday zones and are actively used especially in the summer months, leading to pollution of water in the river with solid domestic waste - polyethylene bags, plastic bottles, household waste, etc. In recent years, the urbanization has increased the number of different types of construction on the territory of the Kasakh River Basin, and the river has started to pollute construction materials, construction materials (cement, nonferrous metals) [42].

Complex assessment of Sevdjur and Kasakh rivers pollution by WQOI method. According to the calculation data for the Sevjur and Kasagh rivers in 1978-2008 the water quality in the Kasakh River corresponded to the 4th (poor) and 5th (bad) classes, while the water in the Sevjur River is of the 5th water quality class, with extremely unclear quality.

The Sevdjur River water is constantly being polluted by household and economic wastewater from large and small dwellings, polluting with a large number of nitrogen and phosphorus compounds, which results in the values of WQOI estimated water does not rise to the 5th class, nor is it also viewed by river flow up to the estuary, change of index values. Based on WQOI values in 1978-1987, during the whole period of the river they had a volatile nature within the limits of Class 5 pollution, reaching the 4th and 5th levels in separate years. ranging from the river spatial pollution, to WQOI constant values (range 19-27). 
Starting from the slopes of Aragats and passing through the small rural communities, upstream from the town of Aparan (sampling point 43), the Kasakh River is a communal, communal, pollution pollution of household waste, which results in the quality of the river water as WQOI is ranked 4th class, and crossing the major cities (sampling points- below the city of Aparan, No44, and below Ashtarak city, No46), the effects of pollution pollution on the river are substantially increased, resulting in the river water quality dropping to 5 th WQ class.

In 2001 from the sampling point above the town of Aparan (No43) to the bottom of the Ashtarak town (No46) belongs to the 4th WQ class, and as a result of the pollution level in the estuary, the 5th class is extremely polluted quality limits.

Table 2.17.

WQOI values for Sevjur and Kasakh rivers for the period of 1978-2008.

\begin{tabular}{|c|c|c|c|}
\hline Sampling points & $\mathbf{1 9 7 8 - 1 9 8 9}$ & $\mathbf{1 9 9 0 - 1 9 9 9}$ & $\mathbf{2 0 0 0 - 2 0 0 8}$ \\
\hline 40 & $25.4-67.1$ & $19.1-56.6$ & $19.0-52.7$ \\
\hline 41 & $16.0-65.9$ & $18.9-26.5$ & $19.3-53.8$ \\
\hline 42 & $24.9-63.8$ & $19.3-26.6$ & $19.3-53.4$ \\
\hline 43 & $26.2-64.9$ & $26.5-75.8$ & $26.4-81.9$ \\
\hline 44 & $19.2-26.8$ & $26.1-65.6$ & $19.1-78.7$ \\
\hline 45 & $26.7-68.8$ & $26.2-63.4$ & $25.7-74.9$ \\
\hline 46 & $19.3-65.9$ & $26.2-58.5$ & $19.5-71.0$ \\
\hline 47 & - & $26.5-63.6$ & $19.4-60.0$ \\
\hline
\end{tabular}

Comprehensive assessment of water quality of the Sevdjur and Kasakh rivers by the WQMI method. According to the long-term monitoring data of the Sevjur and Kasakh 
rivers, the quality of water by WQMI belongs to the 2nd (poorly polluted) water quality class.

Table 2.18. WQMI values for Sevjur and Kasakh rivers for the period of 1978-2008.

\begin{tabular}{|c|c|c|c|}
\hline Sampling points & $\mathbf{1 9 7 8 - 1 9 8 9}$ & $\mathbf{1 9 9 0 - 1 9 9 9}$ & $\mathbf{2 0 0 0 - 2 0 0 8}$ \\
\hline 40 & $75.6-84.3$ & $78.2-89.4$ & $81.7-90.1$ \\
\hline 41 & $74.5-86.9$ & $76.6-88.0$ & $81.1-88.9$ \\
\hline 42 & $70.6-84.4$ & $76.5-86.8$ & $80.7-88.9$ \\
\hline 43 & $80.6-87.0$ & $83.9-89.4$ & $79.5-88.7$ \\
\hline 44 & $70.9-85.8$ & $79.9-89.5$ & $93.1-86.8$ \\
\hline 45 & $83.0-89.3$ & $80.9-88.6$ & $83.1-90.2$ \\
\hline 46 & $60.7-87.4$ & $80.3-88.0$ & $79.0-86.4$ \\
\hline 47 & - & $81.3-85.1$ & $77.6-87.8$ \\
\hline
\end{tabular}

According to the WQMI values, the water of the Sevjur and Kasakh rivers belong to the 2 nd moderate water quality class and is not viewed as an annual change of its values, but down the river flows through major cities (in the case of Sevjur River, view of the town of Vagharshapat, in the case of the river Aparan, sampling point 44, and Ashtarak-sampling point 46, cities). The WQMI values are diminishing, staying within the same order. According to the WQMI values classification, the Sevjur and Kasakh rivers are suitable for use in water supply, recreation, fishery and irrigation purposes, however, due to relatively high levels of pollution in the Kasakh River estuary and Aparan reservoir, water can only be used for water supply purposes only after deep cleansing. 


\subsubsection{Reservoirs in Armenia}

The water quality index methods have been evaluated for the quality and availability of 6 water reservoirs (Akhuryan, Arpi Lake, Aparan, Azat, Yerevan Lake and Kechut) used for irrigation purposes in Armenia. The evaluation of reservoirs' water quality and their suitability for irrigation purposes were made based on the Water Quality Malaysian Index (WQMI), based on 2009-2012 hydrochemical monitoring data.

The WQMI provides for the assessment of the water quality of the water object by the annual data of a small number of hydrochemical indicators, according to the water usability. To calculate the index, the values of oxygen saturation of water, suspended solids, ammonium nitrogen, $\mathrm{pH}, \mathrm{BOD}_{5}, \mathrm{COD}-\mathrm{Cr}$, which can generally characterize the anthropogenic pollution of the water object, are taken.

Table 2.19.

Assessment of water quality and water suitable for irrigation use of reservoirs in Armenia by WQMI in 2009-2012.

\begin{tabular}{|l|c|c|c|c|c|}
\hline Reservoirs & $\mathbf{2 0 0 9}$ & $\mathbf{2 0 1 0}$ & $\mathbf{2 0 1 1}$ & $\mathbf{2 0 1 2}$ & $\begin{array}{c}\text { Water } \\
\text { quality class }\end{array}$ \\
\hline Akhuryan & 75.83 & 65.23 & 61.06 & 59.03 & 3 \\
\hline Arpi Lake & 62.62 & 57.37 & 56.84 & 55.84 & 3 \\
\hline Aparan & 77.83 & 64.29 & 63.37 & 64.05 & 3 \\
\hline Yerevan Lake & 68.17 & 60.39 & 54.60 & 56.92 & 3 \\
\hline Azat & 68.19 & 61.50 & 61.86 & 62.09 & 3 \\
\hline Kechut & 67.32 & 67.12 & 67.46 & 67.50 & 3 \\
\hline
\end{tabular}


The water of the explored reservoirs belongs to the 3rd moderate water quality class and is suitable for irrigation purposes without restrictions.

According to the WQMI values, the quality of water in Aparan, Azat and Kechut reservoirs has remained unchanged during the study period. Akhuryan, Lake Arpi and water quality in Yerevan Lake, on the contrary, have dropped to a 4th, dirty class which limits water use for irrigation purposes. The decrease in water quality of Akhuryan water basin and Yerevan Lake is due to the pollution of major settlements in the river basin, respectively, in Gyumri and Yerevan, with communalhousehold wastewater. As a result of household wastewater pollution, the river water increases with the content of ammonium nitrogen, $\mathrm{BOD}_{5}$ and dependent particles and comes with oxygen deficiency. The deterioration of the water quality of the Arpilha reservoir is due to the improper regulation of the reservoir water regime, which results in the accumulation of particles and organic matter in the water, reduced oxygen content and increased nitrogen compounds. In case of continuous pollution of such reservoirs, the use of water for irrigation purposes is foreseen and then non-eligibility.

\subsection{Assessment of anthropogenic pressure on water qaulity of Sevdjur, Kasakh and Hrazdan rivers}

According to the WQMI values, the water of the Sevjur and Kasakh rivers belong to the $2^{\text {nd }}$ class of poorly polluted quality and is not viewed as an annual change of its values, but down the river flows through major cities (in the case of Sevjur River, 
sampling point №41, downstream Vagharshapat town, in the case of the river Kasakh, downstream Aparan town-sampling point №44, and downstream Ashtarak town- sampling point №46) the WQMI's values are diminishing, staying within the same order. Based on the WQMI's values classification, the Sevjur and Kasakh rivers are suitable for water supply, recreation, fisheries and irrigation purposes. However, due to a relatively high level of pollution in downstream the Kasakh River and in the Aparan reservoir, in this site water can be used only after deep chemical treatment of river water.

Anthropogenic pressure on water quality of the Sevjur, Kasakh and Hrazdan rivers has been determined through the Index of Transfer Quantity of Substance by River Flow (ITQSRF) based on its anthropogenic component (ITQSRF ${ }_{\text {ant }}$ ), as well as the generalized assessment point of the Specific Combinatory Water Quality Index (SCWQI) was used (with the use of fishery standards) to determine the duration of pollution and its level. According to the results obtained in the rivers, the dominant pollutants are nitrite, ammonium, sulphate ions, magnesium and copper.

Based on the WPSCI assessment data, since 1986 the water quality in Sevdjur and Kasakh rivers was characterized by characteristic-average polluted by nitrite ion and copper, and in 1978-1985 and 2001-2008 was characterized by unstablemedium. Based on the assessment results of the ITQSRF ${ }_{\text {ant }}, 54 \%$ of the annual amount of nitrite ion conveyed through the Sevjur River, 57\% in the Kasagh River, and 76\%, and 98\%, respectively, of copper, are caused by anthropogenic factors, and the rest are caused by natural processes. 
Ammonium ion contamination of the water in the rivers is characterized as unstable-average, however, in 1993-2000 pollution level has been dropped to unstable-low. According to ITQSRF $_{\text {ant, }} 72 \%$ of the ion annually transferred through the Sevdjur River and 57\% of the ion in the Kasagh River has an anthropogenic origin. Excess of sulphate ion and magnesiumpermeable fish values were observed in the Sevdjur River, where pollutants pollutants are characterized as characteristiclow (duration and level of magnesium contamination observed as unstable-low in 1978-1985).

In the 90's, sulphate ion contamination has diminished to unstable-average, and magnesium ion contamination has not been observed at all. The high content of sulphate ions and magnesium in the Sevjur River is not anthropogenic and is a peculiarity.

In 1978-2008 the values of the ITQSRF values determined by the hydro-chemical and water-soluble data of the rivers indicate that by the average annual flows of the Sevdjur River, 0.1-1.9 thous. tons of inorganic nitrogen, 0.5-8.3 tons of copper, 12.2-90.2 thousand tons of copper. tons of sulphates, 2.3-13.8 thousand tons of magnesium. The river of Sevdjur flows through the river Kasakh 0.2-0.9 thousand a year. tons of inorganic nitrogen, 0.2-2.0 thousand tons of copper, 1.5-5.7 thousand tons of sulfates and 1.2-3.9 thousand tons of magnesium. Always being under the anthropogenic load of utility-household and economic wastewater in the settlements, the natural background of nitrite, ammonium ions and copper in the Sevdjur River has increased artificially by increasing their ability. At the same time, $35 \%$ of nitrous ion contamination in the Sevdjur River 
water, 33\% of ammonium ion and copper are contracted by anthropogenic water pollution in the Kasakh River.

The results of assessment for 1978-2008, the duration of pollution and pollution level of individual pollutants, such as ammonium, nitrite, sulphate ions, copper, and magnesium, were dominated in total pollution of the water of Hrazdan River.

According to the data, the pollution of the upstream and middle-stream river (before the Yerevan Lake) by nitrite ion in 1978-1992 was defined as unstable-medium and unstable-low, and in subsequent years it was defined as a characteristicaverage along with the increase of anthropogenic load on the river. 
Table 2.20

Characterization of water quality pollution type and level in the Kasakh River.

\begin{tabular}{|c|c|c|c|c|c|c|c|c|c|c|c|c|}
\hline \multirow{2}{*}{ 青嵒 } & \multicolumn{3}{|c|}{$1980-1985$} & \multicolumn{3}{|c|}{ 1986-1992 } & \multicolumn{3}{|c|}{ 1993-1998 } & \multicolumn{3}{|c|}{ 2000-2007 } \\
\hline & $\mathrm{NO}_{2}^{-}$ & $\mathrm{NH}_{4}^{+}$ & $\mathrm{Cu}$ & $\mathrm{NO}_{2}^{-}$ & $\mathrm{NH}_{4}^{+}$ & $\mathrm{Cu}$ & $\mathrm{NO}_{2}^{-}$ & $\mathrm{NH}_{4}^{+}$ & $\mathrm{Cu}$ & $\mathrm{NO}_{2}$ & $\mathrm{NH}_{4}^{+}$ & $\mathrm{Cu}$ \\
\hline 43 & & & & $\begin{array}{c}\text { Char/ } \\
\text { med }\end{array}$ & $\begin{array}{c}\mathrm{St} / \\
\text { med }\end{array}$ & Char/med & Char/med & $\begin{array}{l}\text { Unst/ } \\
\text { low }\end{array}$ & Char/med & Char/med & - & Char/med \\
\hline 44 & & & & $\begin{array}{c}\text { Char/ } \\
\text { med }\end{array}$ & Char/med & Char/med & Char/med & $\begin{array}{c}\text { Char/ } \\
\text { med }\end{array}$ & Char/med & Char/med & - & Char/med \\
\hline 111 & $\mathrm{St} / \mathrm{med}$ & Unst/med & Char/med & $\begin{array}{c}\text { Char/ } \\
\text { med }\end{array}$ & Unst/ low & Char/med & Char/med & $\begin{array}{c}\text { Stable/ } \\
\text { med }\end{array}$ & Char/med & - & - & Char/med \\
\hline 45 & Unst/ low & Unst/med & Unst/med & Unst/ low & Unst/med & Char/med & Char/med & $\begin{array}{c}\text { Unst/ } \\
\text { low }\end{array}$ & $\begin{array}{c}\text { Char/ } \\
\text { med }\end{array}$ & Unst/med & $\begin{array}{c}\text { Char/ } \\
\text { med }\end{array}$ & Char/med \\
\hline 46 & Unst/ low & $\begin{array}{l}\text { Unst/ } \\
\text { med }\end{array}$ & Unst/med & Char/med & Unst/ med & $\begin{array}{c}\text { Char/ } \\
\text { med }\end{array}$ & $\begin{array}{c}\text { Char/ } \\
\text { med }\end{array}$ & Unst/ low & Char/med & Unst/med & Char/med & Char/med \\
\hline 47 & & & & & & & Char $/$ med & Unst/med & Char/med & Unst/med & Unst/med & Char/med \\
\hline
\end{tabular}

Table 2.21

Characterization of water quality pollution type and level in the Sevdjur River.

\begin{tabular}{|c|c|c|c|c|c|c|c|c|c|c|c|c|c|c|c|c|c|c|c|c|}
\hline \multirow{2}{*}{ 哭 } & \multicolumn{5}{|c|}{ 1978-1985 } & \multicolumn{5}{|c|}{ 1986-1992 } & \multicolumn{5}{|c|}{$1993-2000$} & \multicolumn{5}{|c|}{ 2001-2008 } \\
\hline & $\mathrm{NO}_{2}^{-}$ & $\mathrm{NH}_{4}^{+}$ & $\mathrm{SO}_{4}^{-2}$ & Mg & $\mathrm{Cu}$ & $\mathrm{NO}_{2}^{-}$ & $\mathrm{NH}_{4}^{+}$ & $\mathrm{SO}_{4}^{-2}$ & Mg & $\mathrm{Cu}$ & $\mathrm{NO}_{2}^{-}$ & $\mathrm{NH}_{4}^{+}$ & $\mathrm{SO}_{4}^{-2}$ & Mg & $\mathrm{Cu}$ & $\mathrm{NO}_{2}^{-}$ & $\mathrm{NH}_{4}^{-}$ & $\mathrm{SO}_{4}^{-2}$ & $\mathbf{M g}$ & $\mathrm{Cu}$ \\
\hline 40 & $\begin{array}{c}\text { UnSt/ } \\
\text { med }\end{array}$ & $\begin{array}{c}\text { UnSt/ } \\
\text { med }\end{array}$ & $\begin{array}{l}\text { Char/ } \\
\text { low }\end{array}$ & $\begin{array}{l}\text { Unst/ } \\
\text { low }\end{array}$ & $\begin{array}{c}\text { UnSt } \\
\text { med }\end{array}$ & $\begin{array}{l}\text { Char/ } \\
\text { med }\end{array}$ & $\begin{array}{c}\text { UnSt/ } \\
\text { med }\end{array}$ & $\begin{array}{c}\text { Char/ } \\
\text { low }\end{array}$ & $\begin{array}{c}\text { Char/ } \\
\text { low }\end{array}$ & $\begin{array}{l}\text { Char/ } \\
\text { med }\end{array}$ & $\begin{array}{c}\text { Char/ } \\
\text { low }\end{array}$ & - & $\begin{array}{c}\text { UnSt/ } \\
\text { med }\end{array}$ & - & $\begin{array}{l}\text { Char/ } \\
\text { med }\end{array}$ & $\begin{array}{c}\text { Char/ } \\
\text { med }\end{array}$ & $\begin{array}{c}\text { UnSt/ } \\
\text { med }\end{array}$ & $\begin{array}{l}\text { Char/ } \\
\text { low }\end{array}$ & $\begin{array}{c}\text { Char/ } \\
\text { low }\end{array}$ & $\begin{array}{c}\text { Char/ } \\
\text { med }\end{array}$ \\
\hline 41 & $\begin{array}{l}\text { Char/m } \\
\text { ed }\end{array}$ & $\begin{array}{c}\text { UnSt/ } \\
\text { med }\end{array}$ & $\begin{array}{l}\text { Char/ } \\
\text { low }\end{array}$ & $\begin{array}{l}\text { Unst/ } \\
\text { low }\end{array}$ & $\begin{array}{c}\text { St } \\
\text { med }\end{array}$ & $\begin{array}{l}\text { Char/ } \\
\text { med }\end{array}$ & $\mathrm{St} / \mathrm{med}$ & $\begin{array}{c}\text { Char/ } \\
\text { low }\end{array}$ & $\begin{array}{c}\text { Char/ } \\
\text { low }\end{array}$ & $\begin{array}{c}\text { Char/ } \\
\text { med }\end{array}$ & $\begin{array}{c}\text { Char/ } \\
\text { med }\end{array}$ & $\begin{array}{l}\text { Unst/ } \\
\text { low }\end{array}$ & $\begin{array}{c}\text { UnSt } \\
\text { med }\end{array}$ & - & $\begin{array}{c}\text { Char/ } \\
\text { med }\end{array}$ & $\begin{array}{c}\text { Char/ } \\
\text { med }\end{array}$ & $\begin{array}{l}\text { Stable/ } \\
\text { low }\end{array}$ & $\begin{array}{c}\text { Char/ } \\
\text { med }\end{array}$ & $\begin{array}{l}\text { Char/ } \\
\text { low }\end{array}$ & $\begin{array}{c}\text { Char/ } \\
\text { med }\end{array}$ \\
\hline 42 & $\begin{array}{l}\text { Char/m } \\
\text { ed }\end{array}$ & $\begin{array}{c}\text { UnSt/ } \\
\text { med }\end{array}$ & $\begin{array}{l}\text { Char/ } \\
\text { low }\end{array}$ & $\begin{array}{l}\text { Unst/ } \\
\text { low }\end{array}$ & $\begin{array}{c}\text { UnSt } \\
\text { med }\end{array}$ & & & & & & $\begin{array}{l}\text { Char/ } \\
\text { med }\end{array}$ & $\begin{array}{l}\text { Unst/ } \\
\text { low }\end{array}$ & $\begin{array}{c}\text { UnSt/ } \\
\text { med }\end{array}$ & - & $\begin{array}{l}\text { Char/ } \\
\text { med }\end{array}$ & $\begin{array}{l}\text { Char/ } \\
\text { med }\end{array}$ & $\begin{array}{c}\text { UnSt } \\
\text { med }\end{array}$ & $\begin{array}{c}\text { Char/ } \\
\text { med }\end{array}$ & $\begin{array}{l}\text { Char/ } \\
\text { low }\end{array}$ & $\begin{array}{l}\text { Char/ } \\
\text { med }\end{array}$ \\
\hline
\end{tabular}


Table 2.22

Characterization of water quality pollution type and level in the Hrazdan River.

\begin{tabular}{|c|c|c|c|c|c|c|c|c|c|c|c|c|c|c|c|c|c|}
\hline \multirow{2}{*}{ 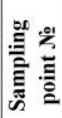 } & \multicolumn{4}{|c|}{$1978-1985$} & \multicolumn{4}{|c|}{ 1986-1992 } & \multicolumn{4}{|c|}{$1993-2000$} & \multicolumn{5}{|c|}{ 2001-2008 } \\
\hline & $\mathrm{NO}_{2}^{-}$ & $\mathrm{NH}_{4}^{+}$ & $\mathrm{SO}_{4}^{-2}$ & $\mathrm{Cu}$ & $\mathrm{NO}_{2}^{-}$ & $\mathrm{NH}_{4}^{+}$ & $\mathrm{SO}_{4}^{-2}$ & $\mathrm{Cu}$ & $\mathrm{NO}_{2}^{-}$ & $\mathrm{NH}_{4}^{+}$ & $\mathrm{SO}_{4}^{-2}$ & $\mathrm{Cu}$ & $\mathrm{NO}_{2}^{-}$ & $\mathrm{NH}_{4}^{+}$ & $\mathrm{SO}_{4}^{-2}$ & Mg & $\mathrm{Cu}$ \\
\hline 51 & $\begin{array}{c}\text { UnSt/ } \\
\text { med }\end{array}$ & $\begin{array}{c}\text { UnSt/ } \\
\text { med }\end{array}$ & $\begin{array}{l}\text { Unst/ } \\
\text { low }\end{array}$ & $\begin{array}{l}\text { Char } \\
\text { /med }\end{array}$ & $\begin{array}{l}\text { Unst/ } \\
\text { low }\end{array}$ & $\mathrm{St} / \mathrm{med}$ & - & $\begin{array}{c}\text { Char/ } \\
\text { med }\end{array}$ & $\begin{array}{c}\text { Char/ } \\
\text { med }\end{array}$ & - & - & $\begin{array}{c}\text { Char/ } \\
\text { med }\end{array}$ & $\begin{array}{c}\text { Char/ } \\
\text { med }\end{array}$ & $\begin{array}{l}\text { Unst/ } \\
\text { low }\end{array}$ & - & $\begin{array}{c}\text { Charac. } \\
\text { / low }\end{array}$ & $\begin{array}{l}\text { Char } \\
\text { /med }\end{array}$ \\
\hline 52 & $\begin{array}{c}\text { UnSt/ } \\
\text { med }\end{array}$ & $\begin{array}{c}\text { UnSt/ } \\
\text { med }\end{array}$ & $\begin{array}{l}\text { Unst/ } \\
\text { low }\end{array}$ & $\begin{array}{l}\text { Char } \\
\text { /med }\end{array}$ & $\begin{array}{l}\text { Unst/ } \\
\text { low }\end{array}$ & $\mathrm{St} / \mathrm{med}$ & $\begin{array}{c}\text { Unst/ } \\
\text { low }\end{array}$ & $\begin{array}{c}\text { Char/ } \\
\text { med }\end{array}$ & $\begin{array}{c}\text { Char/ } \\
\text { med }\end{array}$ & $\begin{array}{l}\text { Unst/ } \\
\text { low }\end{array}$ & - & $\begin{array}{c}\text { Char/ } \\
\text { med }\end{array}$ & $\begin{array}{c}\text { Charac } \\
\text { / low }\end{array}$ & $\begin{array}{c}\text { UnSt/ } \\
\text { med }\end{array}$ & - & $\begin{array}{c}\text { UnSt/ } \\
\text { med }\end{array}$ & $\begin{array}{l}\text { Char } \\
\text { /med }\end{array}$ \\
\hline 53 & $\begin{array}{l}\text { UnSt/ } \\
\text { med }\end{array}$ & $\begin{array}{c}\text { UnSt/ } \\
\text { med }\end{array}$ & - & $\begin{array}{l}\text { Char } \\
\text { /med }\end{array}$ & $\begin{array}{l}\text { Unst/ } \\
\text { low }\end{array}$ & $\begin{array}{c}\text { Char } / \mathrm{m} \\
\text { ed }\end{array}$ & - & $\begin{array}{c}\text { Char/ } \\
\text { med }\end{array}$ & $\begin{array}{c}\text { Stable/ } \\
\text { low }\end{array}$ & - & - & $\begin{array}{l}\text { Char/ } \\
\text { med }\end{array}$ & $\begin{array}{l}\text { Unst/ } \\
\text { low }\end{array}$ & $\begin{array}{c}\text { UnSt/ } \\
\text { med }\end{array}$ & - & $\begin{array}{l}\text { Unst/ } \\
\text { low }\end{array}$ & $\begin{array}{l}\text { Char } \\
\text { /med }\end{array}$ \\
\hline 54 & & & & $\begin{array}{l}\text { Char } \\
\text { /med }\end{array}$ & $\begin{array}{l}\text { Unique/ } \\
\text { med }\end{array}$ & $\begin{array}{c}\text { UnSt/ } \\
\text { med }\end{array}$ & $\begin{array}{c}\text { Stable/ } \\
\text { low }\end{array}$ & $\begin{array}{c}\text { Char/ } \\
\text { med }\end{array}$ & $\mathrm{St} / \mathrm{med}$ & - & - & $\begin{array}{c}\text { Char/ } \\
\text { med }\end{array}$ & $\begin{array}{c}\text { Char/ } \\
\text { med }\end{array}$ & $\begin{array}{l}\text { Unst/ } \\
\text { low }\end{array}$ & $\begin{array}{c}\text { Unique } \\
\text { /low }\end{array}$ & $\begin{array}{l}\text { Unst/ } \\
\text { low }\end{array}$ & $\begin{array}{l}\text { Char } \\
\text { /med }\end{array}$ \\
\hline 112 & & & & $\begin{array}{l}\text { Char } \\
\text { /med }\end{array}$ & & & & $\begin{array}{c}\text { Char/ } \\
\text { med }\end{array}$ & $\begin{array}{c}\text { Char/ } \\
\text { med }\end{array}$ & $\begin{array}{c}\text { Char } / \mathrm{m} \\
\text { ed }\end{array}$ & $\begin{array}{l}\text { Unst/ } \\
\text { low }\end{array}$ & $\begin{array}{c}\text { Char/ } \\
\text { med }\end{array}$ & $\begin{array}{l}\text { Char/ } \\
\text { med }\end{array}$ & $\begin{array}{c}\text { Char/ } \\
\text { med }\end{array}$ & $\begin{array}{l}\text { Unst/ } \\
\text { low }\end{array}$ & $\begin{array}{c}\text { unique/l } \\
\text { ow }\end{array}$ & $\begin{array}{l}\text { Char } \\
\text { /med }\end{array}$ \\
\hline 55 & $\begin{array}{c}\text { Char } / \mathrm{m} \\
\text { ed }\end{array}$ & $\begin{array}{l}\text { Char/ } \\
\text { high }\end{array}$ & $\begin{array}{c}\text { Char/ } \\
\text { low }\end{array}$ & $\begin{array}{l}\text { Char } \\
\text { /med }\end{array}$ & $\mathrm{St} / \mathrm{med}$ & $\begin{array}{c}\text { Char } / \mathrm{m} \\
\text { ed }\end{array}$ & $\begin{array}{c}\text { Char/ } \\
\text { low }\end{array}$ & $\begin{array}{c}\text { Char/ } \\
\text { med }\end{array}$ & $\begin{array}{c}\text { Char/ } \\
\text { med }\end{array}$ & $\begin{array}{l}\text { Char/ } \\
\text { high }\end{array}$ & $\begin{array}{c}\text { Unst/ } \\
\text { low }\end{array}$ & $\begin{array}{c}\text { Char/ } \\
\text { med }\end{array}$ & $\begin{array}{c}\text { Char/ } \\
\text { med }\end{array}$ & $\begin{array}{l}\text { Char/ } \\
\text { high }\end{array}$ & $\begin{array}{c}\text { Stable/ } \\
\text { low }\end{array}$ & $\begin{array}{c}\text { Unst/ } \\
\text { low }\end{array}$ & $\begin{array}{l}\text { Char } \\
\text { /med }\end{array}$ \\
\hline 56 & $\begin{array}{c}\text { Char } / \mathrm{m} \\
\text { ed }\end{array}$ & $\begin{array}{l}\text { Char/ } \\
\text { high }\end{array}$ & $\begin{array}{l}\text { Unst/ } \\
\text { low }\end{array}$ & $\begin{array}{l}\text { Char } \\
\text { /med }\end{array}$ & $\mathrm{St} / \mathrm{med}$ & $\begin{array}{c}\text { Char } / \mathrm{m} \\
\text { ed }\end{array}$ & $\begin{array}{l}\text { Char/ } \\
\text { low }\end{array}$ & $\begin{array}{c}\text { Char/ } \\
\text { med }\end{array}$ & $\begin{array}{c}\text { Char/ } \\
\text { med }\end{array}$ & $\begin{array}{c}\text { Char } / \mathrm{m} \\
\text { ed }\end{array}$ & $\begin{array}{l}\text { Unst/ } \\
\text { low }\end{array}$ & $\begin{array}{c}\text { Char/ } \\
\text { med }\end{array}$ & $\begin{array}{c}\text { Char/ } \\
\text { med }\end{array}$ & $\begin{array}{c}\text { Char/ } \\
\text { med }\end{array}$ & $\begin{array}{c}\text { Char/ } \\
\text { low }\end{array}$ & $\begin{array}{l}\text { Unst/ } \\
\text { low }\end{array}$ & $\begin{array}{l}\text { Char } \\
\text { /med }\end{array}$ \\
\hline
\end{tabular}


Contamination with nitrous ion in the lower streams of the river was characterized as a characteristic-average (Table 2.22) as a result of constant elevated anthropogenic influences of Yerevan. Ammonium ion contamination is defined by upstream and middle-stream of the Hrazdan River, mostly predominantly as unstable-medium (no pollution in ammonia in 1990s), and characteristic-medium in lower streams. As a result of strong urban pollution of the Yerevan city in downstream Hrazdan River, ammonium ion contamination is characterized as characteristic-high.

The assessment data of ITQSRF ${ }_{\text {ant, }}$ based on combined calculations of hydrochemical and hydrological data, was showed that $44 \%$ and $64 \%$ of the pollution of nitrite and ammonium ions in the upstream river have anthropogenic anomalies at are rapidly increasing in the downstream the Yerevan city, making up $80 \%$ and $98 \%$. Due to anthropogenic pressure of Yerevan, the concentration of ammonium ion in the river water was increased. For example, if the area upstream the city of Yerevan (sampling point 54) is transferred to the Hrazdan River at the rate of 0.026-0.393 thousand tones of ammonium ion, and then downstream the city of Yerevan (sampling point 55), this values increased 25.9 times making 0.653-3.955 thousand tons.

The pollution of the Hrazdan River with sulphate ion is characterized as unstable-low and since 1993 it did not registered in the upper streams of the river. According to data of ITQSRF $_{\text {ant }}$, only $7 \%$ of total annual transmitted amounts of anthropogenic origin are due to the river flow and the rest are conditioned by natural factors. 
In water of the Hrazdan River, downstream the city of Yerevan, sulphate ion dominated in the total anthropogenic pollution, which results in an annual quantity of anthropogenic factors, as well as the pollution was characterized as stable and characteristic-low. In 2001-2008 there was also a constant pollution of magnesium in the Hrazdan River, which was characterized as unstable-low. According to data of ITQSRF $F_{\text {ant }}$, $11 \%$ of total pollution had antropogenic origin. The river pollution by copper had been characterized as a characteristicaverage and $96 \%$ of its annual transmitted amounts had an anthropogenic origin based on ITQSRF $F_{\text {ant }}$ values. Such a high percentage shows that being under constant elevated anhydrous load, the natural background of copper in the river water has changed, transforming into a characteristic background changed from anthropogenic impact.

\subsection{Assessment of groundwater quality}

In Armenia groundwater freshwater by chemical composition (according to MGKurlov) belongs to hydrocarbonate-calcium waters, in which several types of waterbearing horizon rocks are distinguished. Hydro-carbonatechloride-sulphate-calcium-sodium waters dominate in the waters of the Andesitophosphate. Hydrocarbonate-chloride-calciumsodium waters dominate in the waters attributed to older volcanic rocks. Hydro-carbonate-calcium-magnesium-sodium waters are found in the sedimentary rock, especially in carbonate rock waters. 
Table 2.23.

Hydrochemical data of Shakhi source for 2008-2012.

\begin{tabular}{|l|c|c|c|}
\hline \multirow{2}{*}{\multicolumn{1}{|c|}{ Parameters }} & \multicolumn{3}{|c|}{ Years } \\
\cline { 2 - 4 } & $\mathbf{2 0 0 8}$ & $\mathbf{2 0 1 1}$ & $\mathbf{2 0 1 2}$ \\
\hline Mineralization, mg/l & 141.60 & 154.90 & 153.30 \\
\hline Total hardness, mmol/l & 0.90 & 0.93 & 1.00 \\
\hline Alkalinity, mmol/L & 1.14 & 1.14 & 1.04 \\
\hline $\mathrm{pH}$ & 7.20 & 7.30 & 7.40 \\
\hline $\mathrm{Cl}, \mathrm{mg} / \mathrm{l}$ & 6.04 & 3.10 & 1.85 \\
\hline $\mathrm{SO}_{4}^{2-}, \mathrm{mg} / \mathrm{l}$ & 9.70 & 5.00 & 10.00 \\
\hline $\mathrm{SiO}_{4}^{2-}, \mathrm{mg} / \mathrm{l}$ & 25.90 & 51.87 & 54.18 \\
\hline $\mathrm{F}^{-}, \mathrm{mg} / \mathrm{l}$ & 0.10 & 0.54 & 0.64 \\
\hline $\mathrm{NH}_{4}^{+}, \mathrm{mg} / \mathrm{l}$ & 0.00 & 0.00 & 0.00 \\
\hline $\mathrm{NO}_{2}^{-}, \mathrm{mg} / \mathrm{l}$ & 0.00 & 0.00 & 0.00 \\
\hline $\mathrm{NO}_{3}^{-}, \mathrm{mg} / \mathrm{l}$ & 0.69 & 0.71 & 2.50 \\
\hline $\mathrm{Fe}_{\text {total. }}, \mathrm{mg} / \mathrm{l}$ & 0.01 & 0.03 & 0.02 \\
\hline $\mathrm{Zn}^{2+}, \mathrm{mg} / \mathrm{l}$ & 0.00 & 0.00 & 0.01 \\
\hline $\mathrm{Cu}^{+2}, \mathrm{mg} / \mathrm{l}$ & 0.00 & 0.00 & 0.00 \\
\hline $\mathrm{Oxydetion}$ & 0.80 & 0.80 & 1.00 \\
\hline
\end{tabular}

The quality of groundwater (drinking water sources) in the southern part of the republic has been studied. The following sources have been examined:

Kapan town- water supplier Surin connection, Halidzor underground sources,

$>$ Sisian town- water supply scheme, Shaki, Zuiaghbyur and Zor Zor sources,

$>$ Goris town- Akner and Mukhturur Sources,

$>$ Meghri and Agarak towns- the source of the water supply source, and Agarak's father respectively. 
Table 2.24

Hydrochemical data of Akner source for 2008-2012.

\begin{tabular}{|l|c|c|c|}
\hline \multirow{2}{*}{ Parameters } & \multicolumn{3}{c|}{ Years } \\
\cline { 2 - 4 } & $\mathbf{2 0 0 8}$ & $\mathbf{2 0 1 1}$ & $\mathbf{2 0 1 2}$ \\
\hline Mineralization, mg/l & 143.9 & 132.8 & 158.1 \\
\hline Total hardness, mmol/l & 0.71 & 0.68 & 0.93 \\
\hline Alkalinity, mmol/L & 0.93 & 1.05 & 0.97 \\
\hline $\mathrm{pH}$ & 7.1 & 7.3 & 7.1 \\
\hline $\mathrm{Cl}^{-}, \mathrm{mg} / \mathrm{l}$ & 2.41 & 1.85 & 2.68 \\
\hline $\mathrm{SO}_{4}^{2-}, \mathrm{mg} / \mathrm{l}$ & 13.9 & 3.8 & 4 \\
\hline $\mathrm{SiO}_{4}^{2-}, \mathrm{mg} / \mathrm{l}$ & 45.4 & 40.14 & 65.4 \\
\hline $\mathrm{F}^{-}, \mathrm{mg} / \mathrm{l}$ & 0.24 & 0.239 & 0.755 \\
\hline $\mathrm{NH}_{4}^{+}, \mathrm{mg} / \mathrm{l}$ & 0.005 & 0 & 0 \\
\hline $\mathrm{NO}_{2}^{-}, \mathrm{mg} / \mathrm{l}$ & 0 & 0 & 0 \\
\hline $\mathrm{NO}_{3}^{-}, \mathrm{mg} / \mathrm{l}$ & 0.25 & 0.79 & 2.42 \\
\hline $\mathrm{Fe}_{\text {total. }}, \mathrm{mg} / \mathrm{l}$ & 0.02 & 0.001 & 0.01 \\
\hline $\mathrm{Zn}^{2+}, \mathrm{mg} / \mathrm{l}$ & 0 & 0 & 0.02 \\
\hline $\mathrm{Cu}^{+2}, \mathrm{mg} / \mathrm{l}$ & 0 & 0 & 0 \\
\hline $\mathrm{Oxydetion}^{2}$ & 0.7 & 0.9 & 0.79 \\
\hline
\end{tabular}

Table 2.25.

Hydrochemical data of Mukhuturyan source for 2008-2012.

\begin{tabular}{|l|c|c|c|}
\hline \multirow{2}{*}{ Parameters } & \multicolumn{3}{|c|}{ Years } \\
\cline { 2 - 4 } & $\mathbf{2 0 0 8}$ & $\mathbf{2 0 1 1}$ & $\mathbf{2 0 1 2}$ \\
\hline Mineralization, mg/l & 177.7 & 140.6 & 115.3 \\
\hline Total hardness, mmol/l & 0.95 & 0.71 & 0.71 \\
\hline Alkalinity, mmol/L & 1.56 & 1.04 & 0.65 \\
\hline $\mathrm{pH}$ & 7.3 & 7.3 & 7.2 \\
\hline $\mathrm{Cl}^{-}, \mathrm{mg} / \mathrm{l}$ & 5.2 & 2.86 & 2.84 \\
\hline $\mathrm{SO}_{4}^{2-}, \mathrm{mg} / \mathrm{l}$ & 7.71 & 4 & 7.2 \\
\hline $\mathrm{SiO}_{4}^{2-}, \mathrm{mg} / \mathrm{l}$ & 30.9 & 46.5 & 44.94 \\
\hline
\end{tabular}




\begin{tabular}{|l|c|c|c|}
\hline \multirow{2}{*}{ Parameters } & \multicolumn{3}{c|}{ Years } \\
\cline { 2 - 4 } & $\mathbf{2 0 0 8}$ & $\mathbf{2 0 1 1}$ & $\mathbf{2 0 1 2}$ \\
\hline $\mathrm{F}^{-}, \mathrm{mg} / \mathrm{l}$ & 0.25 & 0.179 & 0.592 \\
\hline $\mathrm{NH}_{4}^{+}, \mathrm{mg} / \mathrm{l}$ & 0 & 0 & 0.003 \\
\hline $\mathrm{NO}_{2}^{-}, \mathrm{mg} / \mathrm{l}$ & 0 & 0.001 & 0.002 \\
\hline $\mathrm{NO}_{3}^{-}, \mathrm{mg} / \mathrm{l}$ & 1.2 & 0.78 & 1.85 \\
\hline $\mathrm{Fe}_{\text {total }}, \mathrm{mg} / \mathrm{l}$ & 0.01 & 0.009 & 0.02 \\
\hline $\mathrm{Zn}^{2+}, \mathrm{mg} / \mathrm{l}$ & 0 & 0 & 0.01 \\
\hline $\mathrm{Cu}^{+2}, \mathrm{mg} / \mathrm{l}$ & 0 & 0 & 0.01 \\
\hline Oxydetion & 1.2 & 1 & 1.3 \\
\hline
\end{tabular}

Table 2.26.

Hydrochemical data of Setents source for 2008-2012.

\begin{tabular}{|l|c|c|c|}
\hline \multirow{2}{*}{ Parameters } & \multicolumn{3}{|c|}{ Years } \\
\cline { 2 - 4 } & $\mathbf{2 0 0 8}$ & $\mathbf{2 0 1 1}$ & $\mathbf{2 0 1 2}$ \\
\hline Mineralization, mg/l & 212.9 & 190.9 & 246.9 \\
\hline Total hardness, mmol/l & 1.99 & 1.96 & 2.53 \\
\hline Alkalinity, mmol/L & 1.95 & 1.63 & 2.49 \\
\hline $\mathrm{pH}$ & 7.3 & 7.3 & 7.4 \\
\hline $\mathrm{Cl}^{-}, \mathrm{mg} / \mathrm{l}$ & 11.2 & 11 & 5.05 \\
\hline $\mathrm{SO}_{4}^{2-}, \mathrm{mg} / \mathrm{l}$ & 29.9 & 25 & 23.8 \\
\hline $\mathrm{SiO}_{4}^{2-}, \mathrm{mg} / \mathrm{l}$ & 11.7 & 11.5 & 18.12 \\
\hline $\mathrm{F}^{-}, \mathrm{mg} / \mathrm{l}$ & $0 . .15$ & 0.15 & 0.523 \\
\hline $\mathrm{NH}_{4}^{+}, \mathrm{mg} / \mathrm{l}$ & 0.009 & 0.009 & 0.002 \\
\hline $\mathrm{NO}_{2}^{-}, \mathrm{mg} / \mathrm{l}$ & 0 & 0 & 0.008 \\
\hline $\mathrm{NO}_{3}^{-}, \mathrm{mg} / \mathrm{l}$ & 12.1 & 1.57 & 1.93 \\
\hline $\mathrm{Fe}_{\text {total. }}, \mathrm{mg} / \mathrm{l}$ & 0.04 & 0.04 & 0 \\
\hline $\mathrm{Zn}^{2+}, \mathrm{mg} / \mathrm{l}$ & 0.03 & 0.01 & 0.01 \\
\hline $\mathrm{Cu}^{+2}, \mathrm{mg} / \mathrm{l}$ & 0.02 & 0.01 & 0 \\
\hline $\mathrm{Oxydetion}$ & 1.1 & 1.1 & 0.18 \\
\hline
\end{tabular}


Table 2.27.

Hydrochemical data of Geghi source for 2008-2012.

\begin{tabular}{|l|c|c|c|c|}
\hline \multirow{2}{*}{ Parameters } & \multicolumn{4}{|c|}{ Years } \\
\cline { 2 - 5 } & $\mathbf{2 0 0 8}$ & $\mathbf{2 0 0 9}$ & $\mathbf{2 0 1 1}$ & $\mathbf{2 0 1 2}$ \\
\hline Mineralization, mg/l & 267.7 & 252.2 & 134 & 127.7 \\
\hline Total hardness, mmol/l & 2.92 & 3 & 1.32 & 1.32 \\
\hline Alkalinity, mmol/L & 2.51 & 2.3 & 1.39 & 1.28 \\
\hline $\mathrm{pH}$ & 7.5 & 7.5 & 7.3 & 7.3 \\
\hline $\mathrm{Cl}, \mathrm{mg} / \mathrm{l}$ & 11.92 & 12 & 3.14 & 1.36 \\
\hline $\mathrm{SO}_{4}^{2-}, \mathrm{mg} / \mathrm{l}$ & 29.6 & 30 & 6.9 & 7.4 \\
\hline $\mathrm{SiO}_{4}^{2-}, \mathrm{mg} / \mathrm{l}$ & 8.9 & 9 & 9.3 & 13.56 \\
\hline $\mathrm{F}^{-}, \mathrm{mg} / \mathrm{l}$ & 0.08 & 0.1 & 0.044 & 0.2 \\
\hline $\mathrm{NH}_{4}^{+}, \mathrm{mg} / \mathrm{l}$ & 0.009 & 0.01 & 0 & 0.017 \\
\hline $\mathrm{NO}_{2}^{-}, \mathrm{mg} / \mathrm{l}$ & 0 & 0 & 0 & 0.025 \\
\hline $\mathrm{NO}_{3}^{-}, \mathrm{mg} / \mathrm{l}$ & 1.62 & 1.98 & 2.18 & 0.84 \\
\hline $\mathrm{Fe}_{\text {total }}, \mathrm{mg} / \mathrm{l}$ & 0.03 & 0.02 & 0.031 & 0.07 \\
\hline $\mathrm{Zn}^{2+}, \mathrm{mg} / \mathrm{l}$ & 0.01 & 0.01 & 0 & 0 \\
\hline $\mathrm{Cu}^{+2}, \mathrm{mg} / \mathrm{l}$ & 0 & 0 & 0 & 0.01 \\
\hline $\mathrm{Oxydetion}^{-}$ & 1.5 & 1.8 & 1.2 & 0.4 \\
\hline
\end{tabular}

Table 2.28.

Hydrochemical data of Chanakhchi source for 2008-2012.

\begin{tabular}{|l|c|c|c|}
\hline \multirow{2}{*}{ Parameters } & \multicolumn{3}{|c|}{ Years } \\
\cline { 2 - 4 } & $\mathbf{2 0 0 8}$ & $\mathbf{2 0 1 1}$ & $\mathbf{2 0 1 2}$ \\
\hline Mineralization, mg/l & 267.9 & 253.7 & 318.9 \\
\hline Total hardness, mmol/l & 2.67 & 2.64 & 3.21 \\
\hline Alkalinity, mmol/L & 1.98 & 2.38 & 2.8 \\
\hline $\mathrm{pH}$ & 7.4 & 7.3 & 7.5 \\
\hline $\mathrm{Cl}^{-}, \mathrm{mg} / \mathrm{l}$ & 9.81 & 11.82 & 14.2 \\
\hline $\mathrm{SO}_{4}^{2-}, \mathrm{mg} / \mathrm{l}$ & 11.6 & 20.6 & 24.5 \\
\hline $\mathrm{SiO}_{4}^{2-}, \mathrm{mg} / \mathrm{l}$ & 10.5 & 9.8 & 41.52 \\
\hline $\mathrm{F}^{-}, \mathrm{mg} / \mathrm{l}$ & 0.02 & 0.003 & 0.385 \\
\hline
\end{tabular}




\begin{tabular}{|l|c|c|c|}
\hline \multicolumn{1}{|c|}{ Parameters } & \multicolumn{3}{|c|}{ Years } \\
\cline { 2 - 4 } & $\mathbf{2 0 0 8}$ & & $\mathbf{2 0 0 8}$ \\
\hline $\mathrm{NH}_{4}^{+}, \mathrm{mg} / \mathrm{l}$ & 0.007 & 0 & 0.009 \\
\hline $\mathrm{NO}_{2}^{-}, \mathrm{mg} / \mathrm{l}$ & 0.001 & 0.001 & 0.02 \\
\hline $\mathrm{NO}_{3}^{-}, \mathrm{mg} / \mathrm{l}$ & 1.2 & 3.33 & 0.54 \\
\hline $\mathrm{Fe}_{\text {total. }}, \mathrm{mg} / \mathrm{l}$ & 0.06 & 0.059 & 0.03 \\
\hline $\mathrm{Zn}^{2+}, \mathrm{mg} / \mathrm{l}$ & 0.02 & 0 & 0.02 \\
\hline $\mathrm{Cu}^{+2}, \mathrm{mg} / \mathrm{l}$ & 0 & 0.01 & 0 \\
\hline Oxydetion & 1.2 & 0.5 & 1.17 \\
\hline
\end{tabular}

Table 2.29.

Hydrochemical data of Vachagan source for 2008-2012.

\begin{tabular}{|l|c|c|c|}
\hline \multirow{2}{*}{ Parameters } & \multicolumn{3}{|c|}{ Years } \\
\cline { 2 - 4 } & $\mathbf{2 0 0 8}$ & $\mathbf{2 0 1 1}$ & $\mathbf{2 0 1 2}$ \\
\hline Mineralization, mg/l & 230.9 & 261.5 & 230.5 \\
\hline Total hardness, mmol/l & 2.43 & 2.89 & 2.25 \\
\hline Alkalinity, mmol/L & 2.49 & 2.72 & 2.47 \\
\hline $\mathrm{pH}$ & 7.6 & 7.4 & 7.4 \\
\hline $\mathrm{Cl}^{-}, \mathrm{mg} / \mathrm{l}$ & 11.1 & 12.91 & 2.53 \\
\hline $\mathrm{SO}_{4}^{2-}, \mathrm{mg} / \mathrm{l}$ & 12.8 & 10 & 10.2 \\
\hline $\mathrm{SiO}_{4}^{2-}, \mathrm{mg} / \mathrm{l}$ & 12.3 & 11.5 & 16.8 \\
\hline $\mathrm{F}^{-}, \mathrm{mg} / \mathrm{l}$ & 0 & 0.13 & 0.539 \\
\hline $\mathrm{NH}_{4}^{+}, \mathrm{mg} / \mathrm{l}$ & 0.015 & 0 & 0.019 \\
\hline $\mathrm{NO}_{2}^{-}, \mathrm{mg} / \mathrm{l}$ & 0.001 & 0 & 0.009 \\
\hline $\mathrm{NO}_{3}^{-}, \mathrm{mg} / \mathrm{l}$ & 1.95 & 0.61 & 0.7 \\
\hline $\mathrm{Fe}_{\text {total }}, \mathrm{mg} / \mathrm{l}$ & 0.05 & 0.032 & 0.01 \\
\hline $\mathrm{Zn}^{2+}, \mathrm{mg} / \mathrm{l}$ & 0.02 & 0 & 0 \\
\hline $\mathrm{Cu}^{+2}, \mathrm{mg} / \mathrm{l}$ & 0 & 0.01 & 0 \\
\hline $\mathrm{Oxydetion}$ & 1.6 & 1 & 1.04 \\
\hline
\end{tabular}


Table 2.30.

Hydrochemical data of Zvar source for 2008-2012.

\begin{tabular}{|l|c|c|c|}
\hline \multirow{2}{*}{ Parameters } & \multicolumn{3}{|c|}{ Years } \\
\cline { 2 - 4 } & $\mathbf{2 0 0 8}$ & $\mathbf{2 0 1 1}$ & $\mathbf{2 0 1 2}$ \\
\hline Mineralization, mg/l & 93 & 108.5 & 76.1 \\
\hline Total hardness, mmol/l & 1 & 0.96 & 0.57 \\
\hline Alkalinity, mmol/L & 0.82 & 1.11 & 0.63 \\
\hline $\mathrm{pH}$ & 7.1 & 7.3 & 7.1 \\
\hline $\mathrm{Cl}^{-}, \mathrm{mg} / \mathrm{l}$ & 10.9 & 10.7 & 4 \\
\hline $\mathrm{SO}_{4}^{2-}, \mathrm{mg} / \mathrm{l}$ & 8.25 & 6.5 & 6.2 \\
\hline $\mathrm{SiO}_{4}^{2-}, \mathrm{mg} / \mathrm{l}$ & 26.9 & 26.7 & 10.02 \\
\hline $\mathrm{F}^{-}, \mathrm{mg} / \mathrm{l}$ & 0.1 & 0.01 & 0.412 \\
\hline $\mathrm{NH}_{4}^{+}, \mathrm{mg} / \mathrm{l}$ & 0.016 & 0 & 0.021 \\
\hline $\mathrm{NO}_{2}^{-}, \mathrm{mg} / \mathrm{l}$ & 0.002 & 0.002 & 0.024 \\
\hline $\mathrm{NO}_{3}^{-}, \mathrm{mg} / \mathrm{l}$ & 2.1 & 1.43 & 0.38 \\
\hline $\mathrm{Fe}_{\text {total. }}, \mathrm{mg} / \mathrm{l}$ & 0.07 & 0.07 & 0.02 \\
\hline $\mathrm{Zn}^{2+}, \mathrm{mg} / \mathrm{l}$ & 0.02 & 0 & 0 \\
\hline $\mathrm{Cu}^{+2}, \mathrm{mg} / \mathrm{l}$ & 0.2 & 0.01 & 0 \\
\hline $\mathrm{Oxydetion}$ & 1.9 & 1.9 & 2.16 \\
\hline
\end{tabular}

Table 2.31.

Hydrochemical data of Agarak source for 2008-2012.

\begin{tabular}{|l|c|c|}
\hline \multirow{2}{*}{\multicolumn{1}{|c|}{ Parameters }} & \multicolumn{2}{|c|}{ Years } \\
\cline { 2 - 3 } & $\mathbf{2 0 0 9}$ & $\mathbf{2 0 1 2}$ \\
\hline Mineralization, $\mathrm{mg} / \mathrm{l}$ & 295.4 & 94.3 \\
\hline Total hardness, $\mathrm{mmol} / \mathrm{l}$ & 3.2 & 0.75 \\
\hline Alkalinity, $\mathrm{mmol} / \mathrm{L}$ & 1.8 & 0.78 \\
\hline $\mathrm{pH}$ & 7.3 & 7.2 \\
\hline $\mathrm{Cl}^{-}, \mathrm{mg} / \mathrm{l}$ & 18.9 & 3.73 \\
\hline $\mathrm{SO}_{4}^{2-}, \mathrm{mg} / \mathrm{l}$ & 35.2 & 7.5 \\
\hline
\end{tabular}




\begin{tabular}{|l|c|c|}
\hline \multirow{2}{*}{\multicolumn{1}{|c|}{ Parameters }} & \multicolumn{2}{|c|}{ Years } \\
\cline { 2 - 3 } & $\mathbf{2 0 0 9}$ & $\mathbf{2 0 1 2}$ \\
\hline $\mathrm{SiO}_{4}^{2-}, \mathrm{mg} / \mathrm{l}$ & 9.3 & 14.7 \\
\hline $\mathrm{F}, \mathrm{mg} / \mathrm{l}$ & 0.1 & 0.264 \\
\hline $\mathrm{NH}_{4}^{+}, \mathrm{mg} / \mathrm{l}$ & 0 & 0.02 \\
\hline $\mathrm{NO}_{2}^{-}, \mathrm{mg} / \mathrm{l}$ & 0 & 0.023 \\
\hline $\mathrm{NO}_{3}^{-}, \mathrm{mg} / \mathrm{l}$ & 1.5 & 0.86 \\
\hline $\mathrm{Fe}_{\text {total. }}, \mathrm{mg} / \mathrm{l}$ & 0.03 & 0.02 \\
\hline $\mathrm{Zn}^{2+}, \mathrm{mg} / \mathrm{l}$ & 0.02 & 0 \\
\hline $\mathrm{Cu}^{+2}, \mathrm{mg} / \mathrm{l}$ & 0.01 & 0 \\
\hline $\mathrm{Oxyydetion}$ & 1.8 & 1 \\
\hline
\end{tabular}

Table 2.32.

Hydrochemical data of Surin Kap source for 2008-2012.

\begin{tabular}{|l|c|c|}
\hline \multirow{2}{*}{\multicolumn{1}{|c|}{ Parameters }} & \multicolumn{2}{|c|}{ Years } \\
\cline { 2 - 3 } & $\mathbf{2 0 0 8}$ & $\mathbf{2 0 1 1}$ \\
\hline Mineralization, mg/l & 227.3 & 332 \\
\hline Total hardness, mmol/l & 2.4 & 3.81 \\
\hline Alkalinity, mmol/L & 2 & 3.46 \\
\hline $\mathrm{pH}$ & 7.3 & 7.6 \\
\hline $\mathrm{Cl}^{-}, \mathrm{mg} / \mathrm{l}$ & 15 & 12.35 \\
\hline $\mathrm{SO}_{4}^{2-}, \mathrm{mg} / \mathrm{l}$ & 21 & 19 \\
\hline $\mathrm{SiO}_{4}^{2-}, \mathrm{mg} / \mathrm{l}$ & 12.5 & 16.5 \\
\hline $\mathrm{F}^{-}, \mathrm{mg} / \mathrm{l}$ & 0.1 & 0.227 \\
\hline $\mathrm{NH}_{4}^{+}, \mathrm{mg} / \mathrm{l}$ & 0 & 0 \\
\hline $\mathrm{NO}_{2}^{-}, \mathrm{mg} / \mathrm{l}$ & 0 & 0 \\
\hline $\mathrm{NO}_{3}^{-}, \mathrm{mg} / \mathrm{l}$ & 1.4 & 0.63 \\
\hline $\mathrm{Fe}_{\text {total. }}, \mathrm{mg} / \mathrm{l}$ & 0.01 & 0.03 \\
\hline $\mathrm{Zn}^{2+}, \mathrm{mg} / \mathrm{l}$ & 0 & 0 \\
\hline $\mathrm{Cu}^{+2}, \mathrm{mg} / \mathrm{l}$ & 0 & 0 \\
\hline $\mathrm{Oxydetion}$ & 1.5 & 1.7 \\
\hline
\end{tabular}


Based on the main ions content, the underground watersheds are classified according to KEPitiva. In the formula of the water of the iodine composition it contains the anions and cations whose content is more than or equal to $20 \%$ in water, and the letter " $\mathrm{n}$ " is given before the ions, whose number is $5-10 \%$.

Table 2.33.

Hydrochemical composition of drinking water sources.

\begin{tabular}{|c|c|}
\hline Source & Water Composition \\
\hline Shakhi & $\mathrm{HCO}_{3} \mathrm{nSO}_{4} \mathrm{nCI} \mathrm{Ca} \mathrm{Na} \mathrm{nMg}$ \\
\hline Akner & $\mathrm{HCO}_{3} \mathrm{CI} \mathrm{nSO}_{4} \mathrm{Ca} \mathrm{Na} \mathrm{Mg}$ \\
\hline Mukhuturyan & $\mathrm{HCO}_{3} \mathrm{Ca} \mathrm{Na} \mathrm{Mg}$ \\
\hline Zuygaghbyur & $\mathrm{HCO}_{3} \mathrm{nCI} \mathrm{Ca} \mathrm{Mg}$ \\
\hline Zor-Zor & $\mathrm{HCO}_{3} \mathrm{nCI} \mathrm{nSO}_{4} \mathrm{Ca} \mathrm{Mg} \mathrm{Na}$ \\
\hline Setents & $\mathrm{HCO}_{3} \mathrm{SO}_{4} \mathrm{nCI} \mathrm{Ca} \mathrm{Na} \mathrm{Mg}$ \\
\hline Surin Kap & $\mathrm{HCO}_{3} \mathrm{nSO}_{4} \mathrm{nCI} \mathrm{Ca} \mathrm{Mg} \mathrm{nNa}$ \\
\hline Halidzor & $\mathrm{HCO}_{3} \mathrm{nCI} \mathrm{nSO} \mathrm{nSa}_{4} \mathrm{Mg} \mathrm{nNa}$ \\
\hline Agarak well & $\mathrm{HCO}_{3} \mathrm{SO}_{4}$ nCI Ca Mg \\
\hline Geghi & $\mathrm{HCO}_{3} \mathrm{nSO}_{4} \mathrm{nCI} \mathrm{Ca} \mathrm{Mg}$ \\
\hline
\end{tabular}

The results of 2008-2012 (Tables 21 to 30) showed that the water sources in the region are characterized by very low fluorine content and zinc, copper and iron content have not exceeded the norms during the observed period. Nitrogencontaining compounds have been tested for ammonium, nitride and nitrous ions content in water. As a result of studies conducted in 2008-2012, it has become clear that the contents 
of the ions have not exceeded the values of the STC at the time of the study, but a slight increase in the content of nitrous ion in the water of Shaki, Akner, Moukhuturian and Geghi. 


\section{Chapter 3. New proposed indexes}

This chapter is dedicated to the development of the new integrated methods, firstly proposed by us to assess and predict water quality in the freshwater systems.

Proposed by us the new approach allows to study and deeply understand the actual ecological state of a natural water body, assess the water quality, clearly estimate the damages of anthropogenic and natural impacts and their consequences, as well as to predict water quality changes. Using the developed approach by the water resources management agencies will contribute to correct and scientifically based decision-making during issuing water use permits and in developing the program of measures for water resources protection.

Taking into consideration that natural water bodies are complicated and aquatic systems for studies, the proposed methods become possible to observe and assess the natural water bodies on an integrated basis. The principles of the methods can be used in a wide range and they are not focused only on hydrochemical aspects [28, 87-94].

\subsection{Entropic Water Quality Index (EWQI) and Armenian Water Quality Index (AWQI)}

The concept of entropy has many interpretations in various fields of human knowledge. The system interacts with the outside world as a whole. An open system can exchange energy, material and, which is not less important, information with environment. The system consumes information from the 
environment and provides information to environment for act and interact with environment. Shannon was the first who related concepts of entropy and information [87-88]. He was suggested that entropy is the amount of information attributable to one basic message source, generating statistically independent reports. Get any amount of information entropy is equal to the lost. Information entropy for independent random event $\mathrm{x}$ with $\mathrm{N}$ possible states is calculated by the equation:

$$
H=-\sum_{i=1}^{N} p_{i} \log _{2} p_{i},
$$

where $P_{i}$ - probability of frequency of occurrence of an event.

As a result of these works widespread and universal recognition received index Shannon $\mathrm{H}$, sometimes referred to as a Shannon information index of diversity:

$$
H=-\Sigma n_{i} / N \log _{2}\left(n_{i} / N\right) \text {. }
$$

Different processes in hydroecological systems both with increasing and decreasing of entropy can occur. Pollution of water systems can be represented as a system of the hydrochemical parameters (elements), the concentration of which exceeds the MAC. Then in the equation Shannon Pi- probability of the number of cases of MAC excess of $i$-substance or water indicator of total cases of MAC - N, $P_{i}=n_{i} / N$.

The following computational algorithm is used for determination of EWQI and AWQI values:

1. Determines the number of cases of MAC excess of isubstance or indicator of water $-n$.

2. Estimates the total amount of cases the maximum permissible concentration $(N)-N=\sum n$.

3. Computes $\log _{2} N, n \log _{2} n$ and $\sum n \log _{2} n$. 
4. Determines geoecological syntropy (I) and entropy $(\mathrm{H})$ :

$$
I=\sum n \log _{2} n / \mathrm{N} \text { and } H=\log _{2} N-I \text {. }
$$

5. Then EWQI is determined: $E W Q I=H / I$.

6. Further, the total amount multiplicity of MAC exceedances is estimated (M) $M=\sum m$.

7. Computes $\log _{2} M$.

8. Finally, Armenian Water Quality Index was obtained: $A W Q I=E W Q I+0.1 \log _{2} M$.

Therefore, five categories have been suggested to categorize the water qualities which are summarized in Table 3.1.

Table 3.1.

Classes of water quality depending on the value of the EWQI and AWQI.

\begin{tabular}{|c|c|c|c|}
\hline EWQI Value & AWQI Value & $\begin{array}{c}\text { Rating of Water } \\
\text { Quality }\end{array}$ & $\begin{array}{c}\text { Water quality } \\
\text { classes }\end{array}$ \\
\hline$<0.7$ & $<1.1$ & $\begin{array}{c}\text { Excellent water } \\
\text { quality }\end{array}$ & 1 \\
\hline $0.7-1.0$ & $1,1-1,4$ & Good water quality & 2 \\
\hline $1.0-1.4$ & $1.4-1.8$ & Fair water quality & 3 \\
\hline $1.4-1.7$ & $1.8-2.1$ & $\begin{array}{c}\text { Marginal water } \\
\text { quality }\end{array}$ & 4 \\
\hline$>1.7$ & $>2.1$ & Poor water quality & 5 \\
\hline
\end{tabular}

\subsubsection{Hydrological characterization of the Debed river basin}

Debed is the largest river in the Kur River basin. It is composed of two rivers, one of which is Pambak, which originates from Jajur pass, and the other is Dzoraget, which starts from the mountains of the Lori plateau. They are joined by two kilometers north of the Tumanyan station. Debed is the tallest mountain river in Armenia. Debed is composed of Dzoraget and Pambak joints and flows into Khrami River. The 
length is $178 \mathrm{~km}, 152 \mathrm{~km}$ in Armenia and the rest in Georgia. The basin is $4080 \mathrm{~km}^{2}$, of which $3790 \mathrm{~km}^{2}$ is in Armenia with mixed feeding, uneven mode. It hurts in spring, climbing up to 1 $\mathrm{m}$. Debed has important hydropower and irrigation. Most of the orchard gardens in the lower parts of the Noyemberyan region are irrigated by its waters. The most famous streams are Martziget, Ajir, Shnogh.

The water quality monitoring sampling points of the Debed River are located at No. 5-0.5 km downstream from the Marziget River Ground, in the range of 6 to $0.5 \mathrm{~km}$. In the area above the Ayrum and near the border \# 7 .

The Pambak River is the main tributary of Debed. The length of the river is $86 \mathrm{~km}$, the basin is $1370 \mathrm{~km}^{2}$. Surrounded by the north, Bazum, in the south, on the Pambak mountain range. The largest tributary is Getik (Tichkhan), which flows into the Pambak River $52 \mathrm{~km}$ from the estuary. The Pambak River Water Quality Monitoring Points are located at No. 1 to $0.5 \mathrm{~km}$. Above Artashen, no. 2-0.5 km. Down the Spitak, No. $3-$ $0.5 \mathrm{~km}$. Above Vanadzor and No. 4-4 km. Below Vanadzor.

Dzoraget River is one of the Debed Tributaries: The length is $67 \mathrm{~km}$. Starts from the slopes of Javakhk Ridge. Riversidetype river. In the upper stream, on the Lori plain, has a plausible nature, slow down, low, sometimes flooded, and frequently generates scales. Under the river Stepanavan, accepting a large tributary of Tashir, it enters deep, up to 100-120 $\mathrm{m}$ in the gorges. Getahovit narrows into gorge, then narrow and deep cyanide. Dzoraget drainage sand area is $1460 \mathrm{~km}^{2}$. Dzoraget water quality monitoring stations are located at \# 8 to $0.5 \mathrm{~km}$ above $\mathrm{St}$ Stepanavan and to No. 10 river basin. 
Marziget is the right tributary of Debed. The length is 29 $\mathrm{km}$, the basin is $252 \mathrm{~km}^{2}$. Starts from the southern slope of the Mountain of Mount Gugarats, about $2000 \mathrm{~m}$ high. It flows south-west and then to the north-west. Near the town of Tumanyan sank into Debed. It's mixed with spring mushrooms, with summer frosts. Low-activity water-soluble floods are observed. Martziget Water Quality Monitoring Points No. 13 are located in the river Erebuni on the Debed River.

The Tashir River originates from the western part of the Georgian mountains, $4 \mathrm{~km}$ south from the village of Getavan, joining Dzoraget. It has a length of $54 \mathrm{~km}$. One of the streams of the river is Achkajur. Tashir River Water Quality Monitoring Points are located at No. 11-0.5 km. Above Mikhailovka and No. 12-0.5 km. Below Saratovka.

The Akhtala River is the left-hand tributary of Debed. Starts from the mountains of Georgia. The length is $14 \mathrm{~km}$, the drainage basin is $48.42 \mathrm{~km}^{2}$. The main pollution source for the river is the Akhtala tailing dump. The river Debed is near Akhtala settlement. Monitoring No. 14 - is in the estuary.

Integrated assessment results [95-99] for the rivers Debed, Pambak, Zoraget, Tashir, Marciget and Akhtala are shown below in Table 3.2.

$$
\begin{gathered}
\mathrm{AWQI}=(0.809 \pm 0.138)+(0.147 \pm 0.056) \cdot \mathrm{WCI} \\
\mathrm{R}^{2}=0.93854, \mathrm{~N}=12 \\
\mathrm{AWQI}=(0.343 \pm 0.206)+(0.377 \pm 0.092) \cdot \mathrm{SCWQI} \\
\mathrm{R}^{2}=0.77709, \mathrm{~N}=13 \\
\mathrm{AWQI}=(0.180 \pm 0.144)+(1.454 \pm 0.207) \cdot \mathrm{EWQI} \\
\mathrm{R}^{2}=0.90410, \mathrm{~N}=13
\end{gathered}
$$




$$
\begin{gathered}
\mathrm{AWQI}=(2.762 \pm 0.220)-(0.024 \pm 0.003) \cdot \mathrm{CWQI} \\
\mathrm{R}^{2}=0.91115, \mathrm{~N}=13
\end{gathered}
$$

Table 3.2.

WQI data for the Rivers Debed, Pambak, Zoraget, Tashir, Martsiget and Akhtala (2009).

\begin{tabular}{|c|c|c|c|c|c|}
\hline Samp.point & AWQI & EWQI & WCI & CWQI & SCWQI \\
\hline 1 & 1.321 & 0.773 & 1.75 & 62.23 & 1.78 \\
\hline 2 & 1.093 & 0.741 & 1.33 & 75.98 & 2.03 \\
\hline 3 & 1.309 & 0.766 & 2.69 & 62.12 & 2.02 \\
\hline 4 & 1.435 & 0.907 & 3.11 & 61.63 & 2.83 \\
\hline 5 & 0.981 & 0.575 & 1.88 & 73.37 & 2.07 \\
\hline 6 & 1.027 & 0.576 & 2.95 & 68.51 & 2.33 \\
\hline 7 & 1.505 & 0.907 & 5.30 & 56.53 & 2.47 \\
\hline 8 & 0.649 & 0.314 & 1.25 & 80.78 & 1.8 \\
\hline 10 & 0.837 & 0.476 & 1.52 & 80.86 & 1.42 \\
\hline 11 & 1.151 & 0.613 & 1.49 & 64.17 & 1.99 \\
\hline 12 & 1.413 & 0.914 & 1.78 & 64.97 & 2.53 \\
\hline 13 & 0.722 & 0.455 & 1.23 & 78.2 & 1.35 \\
\hline 14 & 1.603 & 0.722 & 30.94 & 41.36 & 3.59 \\
\hline
\end{tabular}

Table 3.3.

WQI Data for the River Debed (2013)

\begin{tabular}{|c|c|c|c|}
\hline \multirow{2}{*}{ Indexes } & \multicolumn{3}{|c|}{ Sampling points } \\
\cline { 2 - 4 } & $\mathbf{5}$ & $\mathbf{6}$ & $\mathbf{7}$ \\
\hline AWQI & 1.6229 & 1.6929 & 1.8929 \\
\hline EWQI & 1.106 & 1.1448 & 1.1868 \\
\hline WCI & 1.9 & 3.94 & 14.38 \\
\hline CWQI & 69.13 & 62.37 & 45.32 \\
\hline SCWQI & 2.84 & 3.13 & 4.29 \\
\hline
\end{tabular}

For river Debed excellant correlation:

$$
\begin{gathered}
\text { AWQI }=(1.596 \pm 0.018)+(0.021 \pm 0.002) \cdot \mathrm{WCI} \\
\mathrm{R}^{2}=0.99505, \mathrm{~N}=3 \\
\mathrm{AWQI}=(1.113 \pm 0.040)+(0.182 \pm 0.011) \cdot \mathrm{SCWQI} \\
\mathrm{R}^{2}=0.99806, \mathrm{~N}=3 \\
\mathrm{AWQI}=(0.053 \pm 0.122)+(1.486 \pm 0.115) \cdot \mathrm{EWQI} \\
\mathrm{R}^{2}=0.97966, \mathrm{~N}=9
\end{gathered}
$$




$$
\begin{gathered}
\mathrm{AWQI}=(2.409 \pm 0.018)-(0.011 \pm 0.001) \cdot \mathrm{CWQI} \\
\mathrm{R}^{2}=0.99965, \mathrm{~N}=3
\end{gathered}
$$

\subsubsection{The rivers Agstev and Getik}

The river Agstev is the right tributary of the Kura. The length is $133 \mathrm{~km}$, the basin area is $2,589 \mathrm{~km}^{2}$. It starts in the territory of Armenia, on the north-western slope of Tezhler mountain - one of the peaks of the Pambak mountain range. In the upper reaches of Agstev there is a mountain river flowing in a narrow wooded gorge, somewhat widening near the city of Dilijan. Below there is a wider valley. The largest tributaries are Bldan, Sarnajur, Voskepar, Getik, Agdan [42]. There are four sections on the Agstev River (monitoring posts): No. 15-1.2 km above Dilijan, No. 16-0.5 km below Dilijan, No. 17-1.0 km above Ijevan, No. $18-8.0 \mathrm{~km}$ below Ijevan. The river Getikik is the right tributary of the river Agstev. The length of the river is $48 \mathrm{~km}$. It originates on the eastern slope of the Sevan Ridge near the top of Kashatakh. On the river Getik there are two sections: No. 19-0.5 km above the town of Chambarak and No. 20 - the mouth of the river [17].

Table 3.4.

Water Quality Indexes for Rivers Aghstev and Getik (2009)

\begin{tabular}{|c|c|l|c|c|c|}
\hline $\begin{array}{c}\text { Sampling } \\
\text { points N }\end{array}$ & AWQI & EWQI & WCI & CWQI & SCWQI \\
\hline 15 & 0.828 & 0.485 & 0.97 & 81.61 & 1.56 \\
\hline 16 & 1.109 & 0.688 & 1.59 & 73.13 & 2.33 \\
\hline 17 & 1.005 & 0.588 & 1.42 & 74.17 & 2.06 \\
\hline 18 & 1.006 & 0.580 & 1.46 & 72.23 & 2.40 \\
\hline 19 & 1.161 & 0.733 & 1.5 & 71.52 & 2.11 \\
\hline 20 & 0.871 & 0.476 & 1.4 & 72.15 & 1.95 \\
\hline
\end{tabular}


Analysis of obtained data $[93,100]$ indicate that $A W Q I$ has liner dependence with $W C I, S C W Q I, E W Q I$ and an inverse dependence with $C W Q I$ :

$$
\begin{gathered}
\text { AWQI }=(0,338 \pm 0,257)+(0,474 \pm 0,183) \cdot \mathrm{WCI} ; \\
\mathrm{R}^{2}=0,79116 ; \mathrm{N}=6 ; \\
\text { AWQI }=(0,358 \pm 0,313)+(0,309 \pm 0,150) \cdot \mathrm{SCWQI} ; \\
\mathrm{R}^{2}=0,71722 ; \mathrm{N}=6 ; \\
\text { AWQI }=(0,271 \pm 0,065)+(1,227 \pm 0,108) \cdot \mathrm{EWQI} ; \\
\mathrm{R}^{2}=0,98481 ; \mathrm{N}=6 ; \\
\text { AWQI }=(2,631 \pm 0,977)-(0,022 \pm 0,013) \cdot \mathrm{CWQI} ; \\
\mathrm{R}^{2}=0,64206 ; \mathrm{N}=6 .
\end{gathered}
$$

For river Aghstev excellent correlation, $\mathrm{AWQI}=(0,408 \pm 0,074)+(0,426 \pm 0,053) \cdot \mathrm{WCI}$;

$$
\mathrm{R}^{2}=0,98468 ; \mathrm{N}=4 ;
$$

AWQI $=(0,417 \pm 0,207)+(0,273 \pm 0,098) \cdot S C W Q I$

$$
\mathrm{R}^{2}=0,89146 ; \mathrm{N}=4 ;
$$

AWQI $=(0,181 \pm 0,119)+(1,377 \pm 0,203) \cdot$ EWQI;

$$
\mathrm{R}^{2}=0,97886 ; \mathrm{N}=4 ;
$$

AWQI $=(2,823 \pm 0,642)-(0,024 \pm 0,009) \cdot \mathrm{CWQI} ;$

$$
\mathrm{R}^{2}=0,89661 ; \mathrm{N}=4 \text {. }
$$

\subsubsection{Rivers Vorotan, Goris and Sisian}

River Vorotan originates in Artsakh Plateau and flows into the river Araz. The length of $178 \mathrm{~km}$ of the river, the river basin of 5,650 square kilometers Mountain River, flows through the winding canyon. Drop $16 \mathrm{~m}$ to $1 \mathrm{~km}$. Major tributaries of Sisian, Lernashen, Goris, Akari [42]. On the Vorotan River are four monitoring post: number 99-0.5 km above with. Gorayr, number 100-1.0 km above the city of Sisian, number 101-2.0 km below 
the city of Sisian, number 102-0.5 km downstream from village Vorotan. River Sisian - right tributary of the Vorotan. The river is $33 \mathrm{~km}$. On Sisian river located positions: number $103-0.5 \mathrm{~km}$ above the Arevis and number 104 - at the mouth of the river. River Goris leght tributary of the Vorotan. Goris is $29 \mathrm{~km}$ long. Two monitoring posts located on the river Goris: number 106$3.0 \mathrm{~km}$ above the city of Goris, number 107-1.5 km below the city of Goris [17].

Table 3.5.

Entropic and Armenian Water Quality Indexes for River Vorotan (2009).

\begin{tabular}{|c|c|c|c|c|c|c|c|c|}
\hline \multirow{3}{*}{$\begin{array}{l}\text { Parameters } \\
\text { and } \\
\text { indicators }\end{array}$} & \multicolumn{8}{|c|}{ Sampling points } \\
\hline & \multicolumn{2}{|r|}{99} & \multicolumn{2}{|r|}{100} & \multicolumn{2}{|c|}{101} & \multicolumn{2}{|r|}{102} \\
\hline & $\mathbf{n}$ & $n \log _{2} n$ & $\mathbf{n}$ & $n \log _{2} n$ & $\mathbf{n}$ & $\underset{n}{n \log _{2}}$ & $\mathbf{n}$ & $n \log _{2} n$ \\
\hline $\mathrm{NO}_{2}^{-}$ & 0 & 0 & 0 & 0 & 6 & 15.51 & 0 & 0 \\
\hline $\mathrm{Al}$ & 11 & 38.03 & 5 & 11.61 & 5 & 11.61 & 11 & 38.03 \\
\hline V & 12 & 43.00 & 12 & 43.00 & 12 & 43 & 12 & 43.00 \\
\hline $\mathrm{Cr}$ & 3 & 4.755 & 2 & 2 & 3 & 4.755 & 2 & 2 \\
\hline $\mathrm{Mn}$ & 0 & 0 & 4 & 8 & 4 & 8 & 3 & 4.755 \\
\hline $\mathrm{Cu}$ & 0 & 0 & 0 & 0 & 0 & 0 & 8 & 24 \\
\hline $\mathrm{Se}$ & 0 & 0 & 0 & 0 & 1 & 0 & 1 & 0 \\
\hline $\mathrm{N}$ & \multicolumn{2}{|r|}{26} & \multicolumn{2}{|r|}{23} & \multicolumn{2}{|r|}{31} & \multicolumn{2}{|r|}{37} \\
\hline$\sum n \log _{2} n$ & \multicolumn{2}{|r|}{85.8} & \multicolumn{2}{|c|}{64.61} & \multicolumn{2}{|c|}{82.875} & \multicolumn{2}{|c|}{111.78} \\
\hline $\mathrm{I}$ & \multicolumn{2}{|r|}{3.29} & \multicolumn{2}{|r|}{2.81} & \multicolumn{2}{|c|}{2.67} & \multicolumn{2}{|r|}{3.02} \\
\hline $\mathrm{H}$ & \multicolumn{2}{|r|}{1.41} & \multicolumn{2}{|c|}{1.711} & \multicolumn{2}{|c|}{2.28} & \multicolumn{2}{|c|}{2.186} \\
\hline EWQI & \multicolumn{2}{|c|}{0.4278} & \multicolumn{2}{|c|}{0.610} & \multicolumn{2}{|c|}{0.8544} & \multicolumn{2}{|r|}{0.724} \\
\hline $\mathrm{M}=\Sigma \mathrm{m}$ & \multicolumn{2}{|r|}{9.9} & \multicolumn{2}{|r|}{24.0} & \multicolumn{2}{|c|}{30.2} & \multicolumn{2}{|r|}{20.1} \\
\hline $\log _{2} M$ & \multicolumn{2}{|r|}{3.305} & \multicolumn{2}{|c|}{4.596} & \multicolumn{2}{|c|}{4.913} & \multicolumn{2}{|c|}{4.327} \\
\hline AWQI & \multicolumn{2}{|c|}{0.7583} & \multicolumn{2}{|c|}{1.0696} & & 3457 & & .1567 \\
\hline
\end{tabular}


Table 3.6.

Entropic and Armenian Water Quality Indexes for River Vorotan

(2010).

\begin{tabular}{|c|c|c|c|c|c|c|c|c|}
\hline \multirow{3}{*}{$\begin{array}{c}\text { Parameters } \\
\text { and } \\
\text { indicators }\end{array}$} & \multicolumn{8}{|c|}{ Sampling points } \\
\hline & \multicolumn{2}{|r|}{99} & \multicolumn{2}{|r|}{100} & \multicolumn{2}{|r|}{101} & \multicolumn{2}{|r|}{102} \\
\hline & $\mathbf{n}$ & $n \log _{2} n$ & $\mathbf{n}$ & $n \log _{2} n$ & $\mathbf{n}$ & $n \log _{2} n$ & $\mathbf{n}$ & $n \log _{2} n$ \\
\hline $\mathrm{NO}_{2}^{-}$ & 0 & 0 & 0 & 0 & 5 & 11.602 & 0 & 0 \\
\hline $\mathrm{Al}$ & 11 & 38.03 & 10 & 33.2 & 10 & 33.2 & 10 & 33.2 \\
\hline $\mathrm{V}$ & 11 & 38.03 & 10 & 33.2 & 10 & 33.2 & 11 & 38.03 \\
\hline $\mathrm{Cu}$ & 4 & 8 & 0 & 0 & 0 & 0 & 7 & 19.64 \\
\hline $\mathrm{N}$ & \multicolumn{2}{|r|}{26} & \multicolumn{2}{|r|}{20} & \multicolumn{2}{|r|}{25} & \multicolumn{2}{|r|}{28} \\
\hline$\sum \log _{2} \mathrm{n}$ & \multicolumn{2}{|c|}{84.055} & \multicolumn{2}{|r|}{66.4} & \multicolumn{2}{|c|}{78.00} & \multicolumn{2}{|r|}{90.87} \\
\hline $\mathrm{I}$ & \multicolumn{2}{|c|}{3.232} & \multicolumn{2}{|r|}{3.32} & \multicolumn{2}{|r|}{3.12} & \multicolumn{2}{|r|}{3.245} \\
\hline $\mathrm{H}$ & \multicolumn{2}{|c|}{1.465} & \multicolumn{2}{|r|}{0.99} & \multicolumn{2}{|r|}{1.52} & \multicolumn{2}{|r|}{1.559} \\
\hline EWQI & \multicolumn{2}{|c|}{0.453} & \multicolumn{2}{|r|}{0.30} & \multicolumn{2}{|r|}{0.48} & \multicolumn{2}{|r|}{0.480} \\
\hline $\mathrm{M}=\Sigma \mathrm{m}$ & \multicolumn{2}{|r|}{13.3} & \multicolumn{2}{|r|}{21.0} & \multicolumn{2}{|r|}{24.8} & \multicolumn{2}{|r|}{14.6} \\
\hline $\log _{2} \mathrm{M}$ & \multicolumn{2}{|c|}{3.731} & \multicolumn{2}{|c|}{4.389} & \multicolumn{2}{|c|}{4.629} & \multicolumn{2}{|r|}{3.865} \\
\hline AWQI & \multicolumn{2}{|c|}{0.8261} & \multicolumn{2}{|c|}{0.7389} & \multicolumn{2}{|c|}{0.9429} & & 0.8665 \\
\hline
\end{tabular}

Table 3.7.

Entropic and Armenian Water Quality Indexes for River Vorotan (2011)

\begin{tabular}{|c|c|c|c|c|c|c|c|c|}
\hline \multirow{2}{*}{\begin{tabular}{c} 
Parameters $\begin{array}{c}\text { and } \\
\text { indicators }\end{array}$ \\
\cline { 2 - 9 }
\end{tabular}} & \multicolumn{2}{|c|}{$\mathbf{9 9}$} & \multicolumn{2}{|c|}{$\mathbf{1 0 0}$} & \multicolumn{2}{|c|}{$\mathbf{1 0 1}$} & \multicolumn{2}{|c|}{$\mathbf{1 0 2}$} \\
\cline { 2 - 9 } & $\mathbf{n}$ & $\mathbf{n l o g}_{2} \mathbf{n}$ & $\mathbf{n}$ & $\mathbf{n} \log _{2} \mathbf{n}$ & $\mathbf{n}$ & $\mathbf{n l o g}_{2} \mathbf{n}$ & $\mathbf{n}$ & $\mathbf{n} \log _{2} \mathbf{n}$ \\
\hline $\mathrm{NH}_{4}^{+}$ & 0 & 0 & 0 & 0 & 6 & 15.510 & 0 & 0 \\
\hline $\mathrm{NO}_{2}^{-}$ & 0 & 0 & 0 & 0 & 6 & 15.510 & 0 & 0 \\
\hline $\mathrm{Al}$ & 6 & 15.510 & 6 & 15.510 & 6 & 15.510 & 10 & 33.2 \\
\hline $\mathrm{V}$ & 7 & 19.64 & 9 & 28.529 & 9 & 28.529 & 11 & 38.03 \\
\hline $\mathrm{Cu}$ & 0 & 0 & 0 & 0 & 5 & 11.610 & 10 & 33.2 \\
\hline $\mathrm{Mn}$ & 0 & 0 & 0 & 0 & 3 & 4.755 & 3 & 4.755 \\
\hline
\end{tabular}




\begin{tabular}{|c|c|c|c|c|}
\hline $\mathrm{N}$ & 13 & 15 & 35 & 34 \\
\hline$\sum \mathrm{nlog} 2 \mathrm{n}$ & 35.15 & 44.03 & 91.42 & 109.18 \\
\hline $\mathrm{I}$ & 2.70 & 2.935 & 2.612 & 3.211 \\
\hline $\mathrm{H}$ & 0.998 & 0.969 & 2.514 & 1.873 \\
\hline $\mathrm{EQWI}$ & 0.369 & 0.330 & 0.962 & 0.583 \\
\hline $\mathrm{M}=\Sigma \mathrm{m}$ & 9.0 & 20.0 & 28.8 & 14.3 \\
\hline $\log _{2} \mathrm{M}$ & 3.168 & 4.319 & 4.845 & 3.835 \\
\hline $\mathrm{AQWI}$ & 0.6858 & 0.7619 & 1.4465 & 0.9665 \\
\hline
\end{tabular}

It was established that the water of the Rivers Rivers Vorotan, Sisian and Goris regularly exceeded the value concentrations of nitrite and ammonium ions, due to water pollution by domestic wastewater. It was shown that water of Rivers is also contaminated by some metals. Thus, in the rivers water is regularly increased MAC of copper, vanadium, aluminum, chrom, manganese and selenium. For example, in 2009 year in the position № 101 of River Vorotan $\mathrm{NO}_{2}^{-}, \mathrm{Al}, \mathrm{V}$, $\mathrm{Cr}, \mathrm{Mn}$ and Se number of MAC increasing cases is 6, 5, 12, 3, 4, and 1 times, respectively. The amount of excess cases of MAC $\mathrm{N}=31, \sum n \log _{2} n=82.875, \mathrm{I}=52.875 / 31=2.67, \mathrm{H}=\log _{2} 31-$ $2.67=2.28$, EWQ I= 2.28/2.67=0.8544. The total amount of the multiplicity of MAC exceedances $-\mathrm{M}=\sum \mathrm{m}=30.2, \log _{2} \mathrm{M}=4.913$, AWGI $=0.8544+0.4913=1.3457($ Table 3.5$)$ 
Table 3.8.

Entropic and Armenian Water Quality Indexes for River Vorotan (2012).

\begin{tabular}{|c|c|c|c|c|c|c|c|c|}
\hline \multirow{3}{*}{$\begin{array}{l}\text { Parameters } \\
\text { and } \\
\text { indicators }\end{array}$} & \multicolumn{8}{|c|}{ Sampling points } \\
\hline & \multicolumn{2}{|r|}{99} & \multicolumn{2}{|r|}{100} & \multicolumn{2}{|r|}{101} & \multicolumn{2}{|r|}{102} \\
\hline & $\mathbf{n}$ & $n \log _{2} n$ & $\mathbf{n}$ & $n \log _{2} n$ & $\mathbf{n}$ & $n \log _{2} n$ & $\mathbf{n}$ & $n \log _{2} n$ \\
\hline $\mathrm{NO}_{2}^{-}$ & 0 & 0 & 0 & 0 & 5 & 11.61 & 0 & 0 \\
\hline $\mathrm{Al}$ & 10 & 33.2 & 8 & 23.98 & 8 & 23.98 & 11 & 38.03 \\
\hline $\mathrm{V}$ & 10 & 33.2 & 12 & 43.00 & 11 & 38.03 & 12 & 43.00 \\
\hline $\mathrm{Cr}$ & 0 & 0 & 4 & 8 & 4 & 8 & 5 & 11.61 \\
\hline $\mathrm{Mn}$ & 0 & 0 & 0 & 0 & 3 & 4.755 & 4 & 8 \\
\hline $\mathrm{Cu}$ & 0 & 0 & 8 & 24 & 8 & 24 & 12 & 43.00 \\
\hline $\mathrm{Se}$ & 0 & 0 & 0 & 0 & 3 & 4.755 & 0 & 0 \\
\hline $\mathrm{N}$ & & 20 & & 32 & & 42 & & 44 \\
\hline$\sum n \log _{2} n$ & & 66.4 & & 8.95 & & 115.1 & & 143.63 \\
\hline I & & 3.32 & & 3.09 & & 2.74 & & 3.26 \\
\hline $\mathrm{H}$ & & 0.99 & & 1.90 & & 2.64 & & 2.196 \\
\hline EWQI & & 0.298 & & 0.61 & & 0.96 & & 0.67 \\
\hline $\mathrm{M}=\Sigma \mathrm{m}$ & & 8.4 & & 22.5 & & 24 & & 14.7 \\
\hline $\log _{2} M$ & & 3.068 & & 4.489 & & 4.582 & & 3.875 \\
\hline AWQI & & .6048 & & .0589 & & 1.418 & & 1.0575 \\
\hline
\end{tabular}


Table 3.9.

Entropic and Armenian Water Quality Indexes for Rivers Sisian and Goris (2009).

\begin{tabular}{|c|c|c|c|c|c|c|c|c|}
\hline \multirow{3}{*}{ Parameters } & \multicolumn{4}{|c|}{ Sisian } & \multicolumn{4}{|c|}{ Goris } \\
\hline & \multicolumn{2}{|r|}{103} & \multicolumn{2}{|c|}{104} & \multicolumn{2}{|c|}{106} & \multicolumn{2}{|r|}{107} \\
\hline & $\mathbf{n}$ & $n \log _{2} n$ & $\mathbf{n}$ & $n \log _{2} n$ & $\mathbf{n}$ & $n \log _{2} n$ & $\mathbf{n}$ & $n \log _{2} n$ \\
\hline $\mathrm{BOD}_{5}$ & 0 & 0 & 0 & 0 & 0 & 0 & 4 & 8 \\
\hline $\mathrm{NH}_{4}^{+}$ & 0 & 0 & 0 & 0 & 0 & 0 & 12 & 43 \\
\hline $\mathrm{NO}_{2}^{-}$ & 0 & 0 & 0 & 0 & 0 & 0 & 12 & 43 \\
\hline $\mathrm{Cu}$ & 3 & 4.75 & 8 & 24 & 0 & 0 & 11 & 38 \\
\hline $\mathrm{V}$ & 0 & 0 & 11 & 38.0 & 12 & 43.0 & 12 & 43 \\
\hline $\mathrm{Al}$ & 5 & 11.6 & 9 & 28.5 & 4 & 8 & 4 & 8 \\
\hline $\mathrm{Mn}$ & 4 & 8 & 0 & 0 & 0 & 0 & 0 & 0 \\
\hline $\mathrm{Cr}$ & 0 & 0 & 0 & 0 & 3 & 4.75 & 5 & 11.6 \\
\hline $\mathrm{Se}$ & 0 & 0 & 0 & 0 & 0 & 0 & 1 & 0 \\
\hline $\mathrm{N}$ & \multicolumn{2}{|r|}{12} & \multicolumn{2}{|c|}{28} & \multicolumn{2}{|r|}{19} & \multicolumn{2}{|r|}{61} \\
\hline$\sum \operatorname{nlog}_{2} n$ & \multicolumn{2}{|c|}{24.35} & \multicolumn{2}{|c|}{90.5} & \multicolumn{2}{|c|}{55.75} & \multicolumn{2}{|c|}{194.6} \\
\hline $\mathrm{I}$ & \multicolumn{2}{|c|}{2.03} & \multicolumn{2}{|c|}{3.231} & \multicolumn{2}{|c|}{2.934} & \multicolumn{2}{|c|}{3.190} \\
\hline $\mathrm{H}$ & \multicolumn{2}{|c|}{1.55} & \multicolumn{2}{|c|}{1.57} & \multicolumn{2}{|c|}{1.311} & \multicolumn{2}{|c|}{2.737} \\
\hline EWQI & \multicolumn{2}{|c|}{0.765} & \multicolumn{2}{|c|}{0.487} & \multicolumn{2}{|c|}{0.447} & \multicolumn{2}{|c|}{0.858} \\
\hline $\mathrm{M}=\sum \mathrm{m}$ & \multicolumn{2}{|c|}{12.7} & \multicolumn{2}{|c|}{10} & \multicolumn{2}{|c|}{16.4} & \multicolumn{2}{|r|}{39.2} \\
\hline $\log _{2} M$ & \multicolumn{2}{|c|}{3.70} & \multicolumn{2}{|c|}{3.32} & \multicolumn{2}{|c|}{4.03} & \multicolumn{2}{|c|}{5.369} \\
\hline AWQI & & 1.135 & & .819 & & .850 & & 1.395 \\
\hline
\end{tabular}

The obtained data [101-103] indicate that along the source to the mouth of the river water quality decreases (Tables 3.33.9). After the cities of Goris and Sisian AWQI increases, this indicates a decline in water quality of Rivers Vorotan and Goris caused by water pollution by domestic wastewater.

Watre quality of River Vorotan, Sisian and Goris also comprehensively evaluate by other indexes: Water Contamination Index (WCI), Canadian Water Quality Index 
(CWQI) and Specific-combinatorial Water Quality Index (SCWQI) are used for evaluation surface water quality in Republic of Armenia (Table 3.10).

Table 3.10.

Water Quality Indexes for Rivers Vorotan, Sisian and Goris (2009).

\begin{tabular}{|c|c|c|c|c|c|}
\hline Sampling points & AWQI & EWQI & WCI & CWQI & SCWQI \\
\hline 99 & 0.7583 & 0.4278 & 1.42 & 86.69 & 1.08 \\
\hline 100 & 1.0696 & 0.610 & 4.36 & 73.30 & 1.67 \\
\hline 101 & 1.3457 & 0.8544 & 4.33 & 70.77 & 2.14 \\
\hline 102 & 1.1567 & 0.724 & 2.12 & 80.05 & 1.76 \\
\hline 103 & 1.135 & 0.765 & 0.80 & 83.77 & 1.30 \\
\hline 104 & 0.819 & 0.487 & 1.30 & 87.25 & 1.47 \\
\hline 106 & 0.850 & 0.447 & 2.88 & 79.99 & 1.45 \\
\hline 107 & 1.395 & 0.858 & 5.76 & 67.55 & 2.16 \\
\hline
\end{tabular}

With the help of a computer program «Origin-6» made an analysis of the linear relationship between AWQI and drugimy water quality index (WQI):

$$
\mathrm{AWQI}=\mathrm{a}+\mathrm{b} \cdot[\mathrm{WQI}] \text {. (3.8) }
$$

A good correlation is obtained also when the rivers Vorotan, Sisian and Goris considered together:

$$
\begin{gathered}
\text { AWQI }=(0.8084 \pm 0.1362)+(0.0897 \pm 0.0410) \cdot \mathrm{WCI} \\
\mathrm{R}^{2}=0.66599, \mathrm{~N}=8 \\
\mathrm{AWQI}=(0.1894 \pm 0.2161)+(0.5383 \pm 0.1296) \cdot \mathrm{SCWQI}, \\
\mathrm{R}^{2}=0.86133, \mathrm{~N}=8 \\
\mathrm{AWQI}=(0.2154 \pm 0.0751)+(1.3155 \pm 0.1125) \cdot \mathrm{EWQI} \\
\mathrm{R}^{2}=0.97875, \mathrm{~N}=8 \\
\mathrm{AWQI}=(3.1810 \pm 0.5838)-(0.0269 \pm 0.0074) \cdot \mathrm{CWQI} \\
\mathrm{R}^{2}=0.82942, \mathrm{~N}=8
\end{gathered}
$$


For the rivers Sisian and Goris good correlation.

$$
\begin{gathered}
\text { AWQI }=(0.838 \pm 0.215)+(0.079 \pm 0.065) \cdot \mathrm{WCI} \\
\mathrm{R}^{2}=0.65178, \mathrm{~N}=4 \\
\text { AWQI }=(0.229 \pm 0.554)+(0.514 \pm 0.340) \cdot \mathrm{SCWQI}, \\
\mathrm{R}^{2}=0.73018, \mathrm{~N}=4 \\
\text { AWQI }=(0.225 \pm 0.154)+(1.290 \pm 0.232) \cdot \mathrm{EWQI}, \\
\mathrm{R}^{2}=0.96899, \mathrm{~N}=4 \\
\text { AWQI }=(3.082 \pm 1.044)-(0.025 \pm 0.013) \cdot \mathrm{CWQI} \\
\mathrm{R}^{2}=0.81023, \mathrm{~N}=4
\end{gathered}
$$

For the river Vorotan gets better correlation .

$$
\begin{gathered}
\text { AWQI }=(0.736 \pm 0.271)+(0.113 \pm 0.081) \cdot \mathrm{WCI}, \\
\mathrm{R}^{2}=0.70050, \mathrm{~N}=4 \\
\text { AWQI }=(0.156 \pm 0.042)+(0.558 \pm 0.024) \cdot \mathrm{SCWQI}, \\
\mathrm{R}^{2}=0.99807, \mathrm{~N}=4 \\
\text { AWQI }=(0.204 \pm 0.083)+(1.343 \pm 0.123) \cdot \mathrm{EWQI}, \\
\mathrm{R}^{2}=0.99170, \mathrm{~N}=4 \\
\text { AWQI }=(3.361 \pm 0.973)-(0.029 \pm 0.013) \cdot \mathrm{CWQI}, \\
\mathrm{R}^{2}=0.85675, \mathrm{~N}=4
\end{gathered}
$$

It was established the correlation between AWQI and other water quality indexes. Analysis of obtained data indicate that AWQI has liner dependence with WCI, SCWQI, EWQI and an inverse dependence with CWQI: 


\subsubsection{Arpa River}

Arpa River originates in north-west of Artsakh Plateau, at an altitude of $3200 \mathrm{~m}$ and flows into the Araks River, on the border of Nakhijevan and Turkey. The length of river is $126 \mathrm{~km}$ (in Armenia 90km), basin - $2630 \mathrm{~km}^{2}$. It flows through the gorges with a big difference in altitude. Mines and waterfalls are fallen into the river near the town Jermuk. Arpa valley is wide in some parts of average flow, the river flows through Araks plain in lower flow [42]. On the Arpa River are five monitoring post: number $83-0.5 \mathrm{~km}$ above the city of Jermuk, number $84-0.5 \mathrm{~km}$ above the city of Vayk, number $85-0.5 \mathrm{~km}$ below the city of Vayk, number $86-0.5 \mathrm{~km}$ above the city of Yeghegnadzor, number $87-0.5 \mathrm{~km}$ below the village Areni [17].

Kechut Reservoir is located on the Arpa River, $3.5 \mathrm{~km}$ south of the resort town of Jermuk. Reservoir has an area of 145 hectares, the total amount - 23 million cubic meters, the average depth - $20 \mathrm{~m}$, coastline length $-8.5 \mathrm{~km}$ [42]. The sampling point for water monitoring in the Kechut reservoir is under the number of 114 [17].

It was established in the river water is regularly increased MAC of copper, vanadium, aluminum, chrom, manganese and selenium. For example, in 2009 year in the position № 85 of River Arpa $\mathrm{NO}_{2}{ }^{-}, \mathrm{V}, \mathrm{Al}, \mathrm{Mn}$ and Se number of MAC increasing cases is $2,11,11,2$, and 1 times, respectively. The amount of excess cases of MAC $-\mathrm{N}=27, \sum \log _{2} n=80.06, \mathrm{I}=80.06 /$ $27=2.96, \mathrm{H}=\log _{2} 27-2.96=4.75-2.96=1.79, \mathrm{EWQI}=\mathrm{G}=$ $1.79 / 2.96=0.604$. The total amount of the multiplicity of MAC exceedances $-\mathrm{M}=\sum \mathrm{m}=12.6, \log _{2} \mathrm{M}=3.653$, AWQI $=$ $0.604+0.3653=0.9693$. 
Table 3.11.

Entropic and Armenian water quality indexes for River Arpa and

Kechut Reservoir.

\begin{tabular}{|c|c|c|c|c|c|c|c|c|c|c|c|c|}
\hline \multirow[t]{3}{*}{ Indicator } & \multicolumn{12}{|c|}{ Sampling points } \\
\hline & \multicolumn{2}{|c|}{83} & \multicolumn{2}{|c|}{84} & \multicolumn{2}{|c|}{85} & \multicolumn{2}{|r|}{86} & \multicolumn{2}{|c|}{87} & \multicolumn{2}{|c|}{114} \\
\hline & $\mathbf{n}$ & $\operatorname{nlog}_{2} n$ & n & $n \log _{2} n$ & $\mathbf{n}$ & $n \log _{2}$ & $\mathbf{n}$ & $n \log _{2} n$ & $\mathbf{n}$ & $n \log _{2} n$ & $\mathbf{n}$ & $n \log _{2} n$ \\
\hline $\mathrm{NO}_{2}^{-}$ & 0 & 0 & 0 & 0 & 2 & 2 & 0 & 0 & 0 & 0 & 0 & 0 \\
\hline $\mathrm{Al}$ & 10 & 33.2 & 9 & 28.5 & 11 & 38 & 11 & 38 & 10 & 33.2 & 10 & 33.2 \\
\hline $\mathrm{V}$ & 10 & 33.2 & 11 & 38 & 11 & 38 & 12 & 43 & 12 & 43 & 10 & 33.2 \\
\hline $\mathrm{Cr}$ & 5 & 11.6 & 0 & 0 & 0 & 0 & 0 & 0 & 4 & 8 & 0 & 0 \\
\hline $\mathrm{Mn}$ & 0 & 0 & 0 & 0 & 2 & 2 & 3 & 4.75 & 0 & 0 & 0 & 0 \\
\hline $\mathrm{Se}$ & 0 & 0 & 1 & 0 & 1 & 0 & 1 & 0 & 1 & 0 & 0 & 0 \\
\hline $\mathrm{N}$ & \multicolumn{2}{|c|}{25} & \multicolumn{2}{|c|}{21} & \multicolumn{2}{|c|}{27} & \multicolumn{2}{|r|}{27} & \multicolumn{2}{|r|}{27} & \multicolumn{2}{|c|}{20} \\
\hline$\sum n \log _{2} n$ & \multicolumn{2}{|c|}{78} & \multicolumn{2}{|c|}{66.54} & \multicolumn{2}{|c|}{80.06} & \multicolumn{2}{|c|}{85.75} & \multicolumn{2}{|c|}{84.2} & \multicolumn{2}{|c|}{66.4} \\
\hline $\mathrm{I}$ & \multicolumn{2}{|c|}{3,12} & \multicolumn{2}{|c|}{3.17} & \multicolumn{2}{|c|}{2,96} & \multicolumn{2}{|c|}{3.18} & \multicolumn{2}{|c|}{3.12} & \multicolumn{2}{|c|}{3.32} \\
\hline $\mathrm{H}$ & \multicolumn{2}{|c|}{1.52} & \multicolumn{2}{|c|}{1,22} & \multicolumn{2}{|c|}{1,79} & \multicolumn{2}{|c|}{1,57} & \multicolumn{2}{|c|}{1.63} & \multicolumn{2}{|c|}{1.0} \\
\hline EWQI & \multicolumn{2}{|c|}{0.488} & \multicolumn{2}{|c|}{0,385} & & 604 & &, 494 & &, 523 & & .301 \\
\hline$M=\Sigma m$ & & 8.1 & & 9.0 & & 2.6 & & 12.5 & & 13.9 & & 6.7 \\
\hline $\log _{2} \mathrm{M}$ & & 016 & & 168 & & 653 & & .642 & & .795 & & .742 \\
\hline AWQI & & 7896 & & 7018 & & 693 & & 8582 & & 9025 & & 5752 \\
\hline
\end{tabular}

Table 3.12.

Data of WQIs for Arpa River and Kechut Reservoir.

\begin{tabular}{|c|c|c|c|c|c|}
\hline Sampling points & AWQI & EWQI & WCI & CWQI & SCWQI \\
\hline $\mathbf{8 3}$ & 0.7896 & 0.488 & 1.14 & 83.78 & 1.60 \\
\hline $\mathbf{8 4}$ & 0.7018 & 0.385 & 1.16 & 82.04 & 1.51 \\
\hline $\mathbf{8 5}$ & 0.9693 & 0.604 & 1.45 & 77.67 & 1.87 \\
\hline $\mathbf{8 6}$ & 0.8582 & 0.494 & 1.45 & 79.47 & 1.76 \\
\hline $\mathbf{8 7}$ & 0.9025 & 0.523 & 1.30 & 76.90 & 1.53 \\
\hline $\mathbf{1 1 4}$ & 0.5750 & 0.301 & 1.22 & 80.68 & 1.9 \\
\hline
\end{tabular}

With the help of a computer program «Origin-6» made an analysis of the linear relationship between AWQI and drugimy water quality index (WQI):

$$
\mathrm{AWQI}=\mathrm{a}+\mathrm{b} \cdot[\mathrm{WQI}]
$$


For the river Arpaa good correlation.

$$
\begin{gathered}
\text { AWQI }=(0.1303 \pm 0.3107)+(0.5492 \pm 0.2378) \cdot \mathrm{WCI} \\
\mathrm{R}^{2}=0.80004, \mathrm{~N}=5 \\
\mathrm{AWQI}=(0.0809 \pm 0.4551)+(0.4615 \pm 0.2741) \cdot \mathrm{SCWQI}, \\
\mathrm{R}^{2}=0.69692, \mathrm{~N}=5 \\
\mathrm{AWQI}=(0.2133 \pm 0.0997)+(1.2650 \pm 0.1985) \cdot \mathrm{EWQI} \\
\mathrm{R}^{2}=0.96514, \mathrm{~N}=5 \\
\mathrm{AWQI}=(3.1571 \pm 0.9495)-(0.0289 \pm 0.0119) \cdot \mathrm{CWQI} \\
\mathrm{R}^{2}=0.81512, \mathrm{~N}=5
\end{gathered}
$$

A good correlation is obtained also when the river Arpa and Kechut Reservoir considered together.

$$
\begin{gathered}
\text { AWQI }=(-0.1095 \pm 0.4916)+(0.7064 \pm 0.3802) \cdot \mathrm{WCI} \\
\mathrm{R}^{2}=0.68059, \mathrm{~N}=6 \\
\mathrm{AWQI}=(3.4995 \pm 1.7499)-(0.0332 \pm 0.0218) \cdot \mathrm{SCWQI}, \\
\mathrm{R}^{2}=0.60529, \mathrm{~N}=6 \\
\mathrm{AWQI}=(0.1846 \pm 0.0548)+(1.3198 \pm 0.1151) \cdot \mathrm{EWQI}, \\
\mathrm{R}^{2}=0.98511, \mathrm{~N}=6,
\end{gathered}
$$

Analysis of obtained data $[92,104]$ indicate that AWQI has liner dependence with WCI, SCWQI, EWQI and an inverse dependence with CWQI. 


\subsubsection{Rivers Voghji, Artsvanik and Geghi}

River Voghji left tributary of the Aras. It rises near the town of Kajaran in Armenia from the merger Kadzharants and Kaputdzhur Rivers. The River is $85 \mathrm{~km}$. Two monitoring posts located on the river Voghji: number 91-1.7 km above the city of Kajaran, number 92-1.8 km below the city of Kajaran, number 93-0.8 km above the city of Kapan, number 94-0.8 km below the city of Kapan. Artsvanik River - left tributary Voghji. The river is $17 \mathrm{~km}$ [42]. On Artsvanik river located positions: number 95-0.5 km above the tailings Artsvanik and number 96 $3.0 \mathrm{~km}$ above the city of Kapan. Geghi River - left tributary Voghji. On the river Geghi located positions: number $97-0.5 \mathrm{~km}$ above s.Adzhabadzha and number 98 - at the mouth of the river [17].

It was established that the water of the River Voghji regularly exceeded the value of $\mathrm{BOD}_{5}$ and concentrations of nitrite and ammonium ions, due to water pollution by domestic wastewater. It was shown that water of River Voghji is also contaminated by some metals. Thus, in the river water is regularly increased MAC of copper, zinc, vanadium, aluminum, cobalt, manganese and selenium. For example, in the position № 92 of River Voghji $\mathrm{BOD}_{5}, \mathrm{NO}_{2}^{-}, \mathrm{NH}_{4}^{+}, \mathrm{V}, \mathrm{Cu}, \mathrm{Al}, \mathrm{Mn}$ and $\mathrm{Se}$ number of MAC increasing cases is $6,5,9,3,12,6,5$ and 9 times, respectively. The amount of excess cases of MAC $-\mathrm{N}=$ $55, \sum n \log _{2} n=159.07, \mathrm{I}=159.07 / 55=2.892, \mathrm{H}=\log _{2} 55-$ $2.892=2.891, \mathrm{G}=2.891 / 2.892=1.0$. The total amount of the 
multiplicity of MAC exceedances - $\mathrm{M}=\sum \mathrm{m}=19.1, \log _{2} \mathrm{M}=4.86$, $\mathrm{A}=1.0+0.448=1.486$.

Table 3.13.

Entropic and Armenian Water Quality Indexes for River Voghji, Artsvanik and Geghi (2009).

\begin{tabular}{|c|c|c|c|c|c|c|c|c|}
\hline \multirow{2}{*}{ Indicator } & \multicolumn{10}{|c|}{ Sampling points } \\
\cline { 2 - 9 } & $\mathbf{9 1}$ & $\mathbf{9 2}$ & $\mathbf{9 3}$ & $\mathbf{9 4}$ & $\mathbf{9 5}$ & $\mathbf{9 6}$ & $\mathbf{9 7}$ & $\mathbf{9 8}$ \\
\hline $\mathrm{N}$ & 14 & 55 & 24 & 79 & 11 & 95 & 8 & 17 \\
\hline$\sum$ nlog2n & 38 & 159.07 & 68.54 & 250.71 & 23.51 & 329.65 & 16 & 43.97 \\
\hline $\mathrm{I}$ & 2.714 & 2.892 & 2.858 & 3.173 & 2.131 & 3.47 & 2.0 & 2.586 \\
\hline $\mathrm{H}$ & 1.086 & 2.891 & 1.734 & 3.131 & 1.317 & 3.046 & 1.0 & 1.495 \\
\hline $\mathrm{G}$ & 0.4 & 1.0 & 0.607 & 0.987 & 0.618 & 0.878 & 0.5 & 0.578 \\
\hline $\mathrm{M}=\sum \mathrm{m}$ & 5.5 & 19.1 & 12.8 & 119.1 & 8 & 63.1 & 5.3 & 6.0 \\
\hline $\log _{2} \mathrm{M}$ & 2.46 & 4.86 & 3.54 & 6.83 & 3.0 & 5.9 & 2.4 & 2.58 \\
\hline $\mathrm{AWQI}$ & 0.646 & 1.486 & 0.961 & 1.67 & 0.918 & 1.475 & 0.74 & 0.836 \\
\hline
\end{tabular}

Table 3.14.

Entropic and Armenian Water Quality Indexes for Rivers Voghji, Artsvanik and Geghi (2009-2012).

\begin{tabular}{|c|c|c|c|c|c|c|c|c|}
\hline \multirow{2}{*}{$\begin{array}{c}\text { Sampling } \\
\text { points }\end{array}$} & \multicolumn{2}{|c|}{2009} & \multicolumn{2}{c|}{ 2010 } & \multicolumn{2}{c|}{ 2011 } & \multicolumn{2}{c|}{ 2012 } \\
\hline & EWQI & AWQI & EWQI & AWQI & EWQI & AWQI & EWQI & AWQI \\
\hline 91 & 0.4 & 0.646 & 0 & 0.2 & 0 & 0.158 & 0.61 & 0.98 \\
\hline 92 & 1 & 1.486 & 0.8 & 1.3 & 0.88 & 1.39 & 0.94 & 1.49 \\
\hline 93 & 0.607 & 0.961 & 0.3 & 0.71 & 0.33 & 0.74 & 0.96 & 1.30 \\
\hline 94 & 0.987 & 1.67 & 0.73 & 1.41 & 0.92 & 1.66 & 1.03 & 1.77 \\
\hline 95 & 0.618 & 0.918 & 0.49 & 0.79 & 0.74 & 1.04 & 0.84 & 1.12 \\
\hline 96 & 0.878 & 1.475 & 0.82 & 1.37 & 1.02 & 1.56 & 1.17 & 1.77 \\
\hline 97 & 0.5 & 0.74 & 0 & 0.07 & 0.43 & 0.73 & 0.87 & 1.24 \\
\hline 98 & 0.578 & 0.836 & 0.32 & 0.51 & 0.33 & 0.58 & 0.25 & 0.51 \\
\hline
\end{tabular}

The obtained data [105] indicate that along the source to the mouth of the river water quality decreases. After the cities of Kajaran and Kapan AWQI increases, this indicates a decline in 
water quality of River Voghji caused by water pollution by domestic wastewater.

Quality of River Voghji, Artsvanik and Geghi water also comprehensively evaluate by other indexes: WCI, EWQI, CWQI, SCWQI (Table 3.15).

Table 3.15.

Water Quality Indexes for Rivers Voghji, Artsvanik and Geghi (2009).

\begin{tabular}{|c|c|c|c|c|c|}
\hline $\begin{array}{c}\text { Sampling } \\
\text { points }\end{array}$ & AWQI & EWQI & WCI & CWQI & SCWQI \\
\hline 91 & 0.646 & 0.4 & 0.87 & 86.05 & 1.21 \\
\hline 92 & 1.486 & 1 & 6.84 & 61.26 & 2.79 \\
\hline 93 & 0.961 & 0.607 & 1.77 & 79.48 & 1.71 \\
\hline 94 & 1.67 & 0.987 & 16.68 & 48.68 & 2.89 \\
\hline 95 & 0.918 & 0.618 & 1.3 & 85.75 & 1.19 \\
\hline 96 & 1.475 & 0.878 & 3.69 & 54.03 & 2.67 \\
\hline 97 & 0.74 & 0.5 & 0.73 & 88.69 & 1.34 \\
\hline 98 & 0.836 & 0.578 & 1 & 84.24 & 1.83 \\
\hline
\end{tabular}

Analysis of obtained data indicate that AWQI has liner dependence with WCI, SCWQI, EWQI and an inverse dependence with CWQI.

$$
\begin{gathered}
\text { AWQI }=(0.845 \pm 0.108)+(0.059 \pm 0.017) \cdot \mathrm{WCI} \\
\mathrm{R}^{2}=0.82579, \mathrm{~N}=8 \\
\text { AWQI }=(0.088 \pm 0.140)+(0.514 \pm 0.067) \cdot \mathrm{SCWQI} \\
\mathrm{R}^{2}=0.95168, \mathrm{~N}=8 \\
\text { AWQI }=-(0.082 \pm 0.093)+(1.686 \pm 0.129) \cdot \mathrm{EWQI} \\
\mathrm{R}^{2}=0.98297, \mathrm{~N}=8 \\
\text { AWQI }=(2.824 \pm 0.164)-(0.023 \pm 0.002) \cdot \mathrm{CWQI} \\
\mathrm{R}^{2}=0.97505, \mathrm{~N}=8
\end{gathered}
$$


Thus, for the first time using AWQI the quality of Rivers Voghji, Artsvanik and Geghi water evaluate. It was shown that from the source to the mouth of the river there is an increase in the value of the AWQI, which indicates the decline in the quality of water of the rivers from the first to the second class of pollution. After the cities of Kajaran and Kapan AWQI increases, indicating a decrease in water quality due to pollution of water River Vohchi by domestic wastewaters. It was established the correlation between AWQI and other water quality indexes.

\subsubsection{Rivers Akhuryan, Ashotsk and Karkachun}

Akhuryan is a river running along the Armenian plateau in the South Caucasus. It is the left tributary of Araks . In the upper current flows through the territory of Armenia, in the lower one - along the border of Armenia with Turkey. It flows from the Arpi lich reservoir, flows into the Araks near the village of Bagaran. The river Akhuryan has length of $186 \mathrm{~km}$ and river basin of $9670 \mathrm{~km}^{2}$ [42]. There are five monitoring posts on the Akhuryan River: № $31-0.5 \mathrm{~km}$ above Amasia City; № $32-1.0$ km below Amasia City; № 33 - 1.0 km above Gyumri City; № 34 - $5.0 \mathrm{~km}$ below Gyumri City; № $35-0.5 \mathrm{~km}$ below Ervandashat village [17].

The river Ashotsk has length of $20 \mathrm{~km}$ and river basin of $197 \mathrm{~km}^{2}$, it is the left tributary of the Akhuryan river. Two monitoring posts, № $36-0.5 \mathrm{~km}$ belowe the Artashen village and № 37 - at the mouth of the river. The river Karkachun has length of $55 \mathrm{~km}$ and river basin of $1220 \mathrm{~km}^{2}$, it is the left 
tributary of the Akhuryan river. Monitoring posts, № $38-0.5$ $\mathrm{km}$ belowe the Garibjanyan village.

Table 3.15.

Entropic and Armenian water quality indexes for river Akhurtan.

\begin{tabular}{|c|c|c|c|c|c|c|c|c|c|c|}
\hline Positions & \multicolumn{2}{|r|}{31} & \multicolumn{2}{|r|}{32} & \multicolumn{2}{|r|}{33} & \multicolumn{2}{|r|}{34} & \multicolumn{2}{|r|}{35} \\
\hline Indicator & $\mathbf{n}$ & $n \log _{2} n$ & $\mathbf{n}$ & $n \log _{2} n$ & $\mathbf{n}$ & $n \log _{2} n$ & $\mathbf{n}$ & $n \log _{2} n$ & $\mathbf{n}$ & $n \log _{2} n$ \\
\hline $\mathrm{NO}_{2}^{-}$ & 0 & 0 & 0 & 0 & 0 & 0 & 6 & 15.5 & 0 & 0 \\
\hline $\mathrm{NH}_{4}^{+}$ & 0 & 0 & 0 & 0 & 0 & 0 & 6 & 15.5 & 0 & 0 \\
\hline $\mathrm{Al}$ & 6 & 15.5 & 7 & 19.64 & 7 & 19.64 & 7 & 19.64 & 5 & 11.6 \\
\hline $\mathrm{V}$ & 6 & 15.5 & 7 & 19.64 & 7 & 19.64 & 7 & 19.64 & 7 & 19.64 \\
\hline $\mathrm{Cu}$ & 4 & 8 & 4 & 8 & 6 & 15.5 & 7 & 19.64 & 4 & 8 \\
\hline$\overline{\mathrm{Mn}}$ & 0 & 0 & 4 & 8 & 6 & 15.5 & 6 & 15.5 & 4 & 8 \\
\hline $\mathrm{Fe}$ & 0 & 0 & 0 & 0 & 3 & 4.75 & 4 & 8 & 0 & 0 \\
\hline $\mathrm{Cr}$ & 0 & 0 & 0 & 0 & 0 & 0 & 5 & 11.6 & 2 & 2 \\
\hline $\mathrm{N}$ & & 16 & & 22 & & 29 & & 48 & & 22 \\
\hline$\sum \mathrm{n} \log _{2} \mathrm{n}$ & & 39 & & 55.28 & & 75.03 & & 05.38 & & 49.24 \\
\hline I & & 2.4375 & & 2.512 & & 2,59 & & .1954 & & 2.238 \\
\hline $\mathrm{H}$ & & 1.5625 & & 1,945 & & 2.265 & & 3.386 & & 2.219 \\
\hline EWQI & & 0.641 & & 0,774 & & .8745 & & .5423 & & 0,991 \\
\hline $\mathrm{M}=\Sigma \mathrm{m}$ & & 17.8 & & 20.4 & & 32.6 & & 42 & & 17.8 \\
\hline $\log _{2} \mathrm{M}$ & & 4.151 & & 4.348 & & 5.024 & & 5.389 & & 4.151 \\
\hline AWQI & & 1.056 & & .2088 & & .3469 & & 2.081 & & .4065 \\
\hline
\end{tabular}

It was established in the river Akhuryan water is regularly increased MAC of copper, vanadium, aluminum, chrom, manganese and iron. For example, in the position № 34 of river Akhuryan $\mathrm{NO}_{2}^{-}, \mathrm{NH}_{4}^{+}, \mathrm{Al}, \mathrm{V}, \mathrm{Cu}, \mathrm{Mn}, \mathrm{Fe}$ and $\mathrm{Cr}$ number of MAC increasing cases is $6,6,7,7,7,6,4$ and 5 times, respectively. The amount of excess cases of MAC $-\mathrm{N}=46$, $\sum \mathrm{n} \log _{2} n=105.38, \mathrm{I}=105.38 / 48=2.195, \mathrm{H}=\log _{2} 48-2.195$ $=5.581-2.195=3.386, \mathrm{EWQI}=\mathrm{G}=3.386 / 2.195=1.5423$. The total amount of the multiplicity of MAC exceedances - 
$\mathrm{M}=\sum \mathrm{m}=42, \log _{2} \mathrm{M}=5.389, \mathrm{AWQI}=1.5423+0.5389=2.081$

(Table 3.15).

Table 3.16.

Entropic and Armenian water quality indexes

for rivers Ashotsk and Karkachun.

\begin{tabular}{|c|c|c|c|c|c|c|}
\hline \multirow{3}{*}{$\begin{array}{c}\text { Parameters } \\
\text { and Indicators }\end{array}$} & \multicolumn{4}{|c|}{ Ashotsk } & \multirow{2}{*}{\multicolumn{2}{|c|}{$\begin{array}{c}\text { Karkachun } \\
38\end{array}$}} \\
\hline & \multicolumn{2}{|c|}{36} & \multicolumn{2}{|r|}{37} & & \\
\hline & $\mathbf{n}$ & $n \log _{2} n$ & $\mathbf{n}$ & $n \log _{2} n$ & $\mathbf{n}$ & $n \log _{2} n$ \\
\hline $\mathrm{NO}_{2}^{-}$ & 0 & 0 & 0 & 0 & 7 & 19.64 \\
\hline $\mathrm{NH}_{4}^{+}$ & 0 & 0 & 0 & 0 & 5 & 11.6 \\
\hline $\mathrm{Al}$ & 4 & 8 & 6 & 15.5 & 5 & 11.6 \\
\hline $\mathrm{V}$ & 1 & 0 & 6 & 15.5 & 7 & 19.64 \\
\hline $\mathrm{Cu}$ & 0 & 0 & 4 & 8 & 6 & 15.5 \\
\hline $\mathrm{Mn}$ & 0 & 0 & 0 & 0 & 6 & 15.5 \\
\hline $\mathrm{N}$ & \multicolumn{2}{|r|}{5} & \multicolumn{2}{|r|}{16} & \multicolumn{2}{|r|}{36} \\
\hline$\sum n \log _{2} n$ & \multicolumn{2}{|c|}{8} & \multicolumn{2}{|r|}{39} & \multicolumn{2}{|c|}{93.48} \\
\hline I & \multicolumn{2}{|c|}{1.6} & \multicolumn{2}{|c|}{2.4375} & \multicolumn{2}{|r|}{2.59} \\
\hline $\mathrm{H}$ & \multicolumn{2}{|c|}{0.72} & \multicolumn{2}{|c|}{1.5625} & \multicolumn{2}{|c|}{2.576} \\
\hline EWQI & \multicolumn{2}{|c|}{0.45} & \multicolumn{2}{|c|}{0.641} & \multicolumn{2}{|c|}{0.995} \\
\hline $\mathrm{M}=\Sigma \mathrm{m}$ & \multicolumn{2}{|c|}{4.1} & \multicolumn{2}{|c|}{15.1} & \multicolumn{2}{|r|}{29.8} \\
\hline $\log _{2} M$ & \multicolumn{2}{|c|}{2.03} & \multicolumn{2}{|c|}{3.914} & \multicolumn{2}{|c|}{4.894} \\
\hline AWQI & \multicolumn{2}{|c|}{0.653} & \multicolumn{2}{|c|}{1.032} & \multicolumn{2}{|c|}{1.4844} \\
\hline
\end{tabular}

It was shown that from the source to the mouth of the river there is an increase in the value of the EWQI, which indicates the decline in the quality of water of the rivers from the first to the fourth class of pollution. After the cities of Amasia and Gyumri AWQI increases, indicating a decrease in water quality due to pollution of water in the River Akhuryan by domestic wastewaters. 
It was established in the river Ashotsk water is regularly increased MAC of copper, vanadium, aluminum. It has been shown that from the source to the river mouth there is an increase in the cost of AWQI, however, water quality remains of the first class.

For the river Karkachun water quality of the second class. For example, in the position № 38 of River Karkachun $\mathrm{NO}_{2}^{-}$, $\mathrm{NH}_{4}^{+}, \mathrm{Al}, \mathrm{V}, \mathrm{Cu}$ and $\mathrm{Mn}$ number of MAC increasing cases is 7, 5, 5, 7, 6, and 6 times, respectively (Table 3.16).

Quality of rivers Akhurtan, Ashotsk and Karkachun water also comprehensively evaluate by other indexes: WCI, EWQI, CWQI, SCWQI (Table 3.17).

Table 3.17.

WQI for the rivers Akhurtan, Ashotsk and Karkachun.

\begin{tabular}{|c|c|c|c|c|c|}
\hline $\begin{array}{c}\text { Sampling } \\
\text { points }\end{array}$ & AWQI & EWQI & WQI & CWQI & SCWQI \\
\hline 31 & 1.0561 & 0.641 & 1.78 & 71.58 & 1.77 \\
\hline 32 & 1.2088 & 0.774 & 1.81 & 68.37 & 1.96 \\
\hline 33 & 1.3469 & 0.8745 & 2.65 & 63.04 & 2.01 \\
\hline 34 & 2.081 & 1.5423 & 4.87 & 57.04 & 2.64 \\
\hline 35 & 1.4065 & 0.991 & 2.09 & 71.4 & 2.17 \\
\hline 36 & 0.653 & 0.45 & 0.64 & 92.2 & 0.92 \\
\hline 37 & 1.032 & 0.641 & 1.63 & 68.51 & 1.44 \\
\hline 38 & 1.4844 & 0.995 & 4.0 & 58.99 & 2.15 \\
\hline
\end{tabular}

With the help of a computer program «Origin-6» is done an analysis of the linear relationship between EWQI and other WQI: EWQI $=a+b$ (WQI). A good correlation is obtained also when the rivers Akhurtan, Ashotsk and Karkachun are considered together: 


$$
\begin{gathered}
\text { EWQI }=(0,334 \pm 0,146)+(0,219 \pm 0,050) \cdot \mathrm{WCI} \\
\mathrm{R}^{2}=0,89103 ; \mathrm{N}=7 \\
\mathrm{EWQI}=-(0,659 \pm 0,267)+(0,783 \pm 0,130) \cdot \mathrm{SCWQI} \\
\mathrm{R}^{2}=0,93702 ; \mathrm{N}=7 \\
\mathrm{EWQI}=-(0,271 \pm 0,040)+(869 \pm 0,029) \cdot \mathrm{AWQI} \\
\mathrm{R}^{2}=0,99732 ; \mathrm{N}=7 \\
\mathrm{EWQI}=(3.488 \pm 1.032)-(0.039 \pm 0,016) \cdot \mathrm{CWQI} \\
\mathrm{R}^{2}=0,74469 ; \mathrm{N}=7
\end{gathered}
$$

Thus, the correlation between EWQI and other WQI is established. Analysis of obtained data [94, 106] indicates that EWQI has liner dependence on WCI, SCWQI, AWQI and an inverse dependence on CWQI.

\subsubsection{Water Quality Indexes for Rivers Sevdjur, Kasakh and Aparan}

The Sevjur River flows from the springs of the Aragats mountain massif and flows into the Araks River. The length of the river is $40 \mathrm{~km}$, the area of the basin is $1610 \mathrm{~km}^{2}$. In comparison with other rivers, Armenia has one of the most stable regimes. The current of the river is very slow. The main tributary of Sevjur is the Kasaha River [27]. There are three monitoring posts on the Sevjur River: No. 40 - $10 \mathrm{~km}$ above the town of Vagarshapat, No. 41 - $11 \mathrm{~km}$ south-west of Vagarshapat No. 42 - 0.5 km below Ranchpar village [17].

The Kasakh River is the left tributary of the Sevjur River. The source of the river is located at the foot $(3200 \mathrm{~m})$ of Mount Aragats. The length of the river is $89 \mathrm{~km}$. The main tributaries of Kasaha are the rivers Gecharot and Amberd. In the middle 
reaches, Kasakh forms a canyon with a depth of up to $200 \mathrm{~m}$ and a length of $10 \mathrm{~km}$. The monitoring posts of the Kasakh River are located: No. 43 - $0.5 \mathrm{~km}$ above Aparan, No. 44 - $0.5 \mathrm{~km}$ below Aparan No. 45 - $1.0 \mathrm{~km}$ above the city of Ashtarak, No. 46 - 3.5 km lower than the city of Ashtarak, No. 47 - the mouth of the river.

Table 3.19

Entropic and Armenian Water Quality Indexes for River Sevdjur (2009).

\begin{tabular}{|c|c|c|c|c|c|c|}
\hline \multirow{3}{*}{ Indicator } & \multicolumn{6}{|c|}{ Sampling points } \\
\hline & \multicolumn{2}{|c|}{40} & \multicolumn{2}{|c|}{41} & \multicolumn{2}{|c|}{42} \\
\hline & $\mathbf{n}$ & $n \log _{2} n$ & $\mathbf{n}$ & $n \log _{2} n$ & $\mathbf{n}$ & $n \log _{2} n$ \\
\hline $\mathrm{NO}_{2}^{-}$ & 12 & 43.0 & 12 & 43.0 & 12 & 43.0 \\
\hline $\mathrm{SO}_{4}^{-}$ & 12 & 43.0 & 12 & 43.0 & 11 & 38.0 \\
\hline $\mathrm{Cu}$ & 8 & 24 & 10 & 33.2 & 8 & 24 \\
\hline $\mathrm{V}$ & 12 & 43.0 & 12 & 43.0 & 12 & 43.0 \\
\hline $\mathrm{Al}$ & 5 & 11.61 & 6 & 15.51 & 7 & 19.64 \\
\hline $\mathrm{Cr}$ & 11 & 38.0 & 11 & 38.0 & 11 & 38.0 \\
\hline $\mathrm{Mn}$ & 10 & 33.2 & 11 & 38.0 & 11 & 38.0 \\
\hline $\mathrm{Br}$ & 11 & 38.0 & 10 & 33.2 & 7 & 19.64 \\
\hline $\mathrm{Se}$ & 11 & 38.0 & 11 & 38.0 & 11 & 38.0 \\
\hline $\mathrm{N}$ & \multicolumn{2}{|c|}{92} & \multicolumn{2}{|c|}{95} & \multicolumn{2}{|c|}{90} \\
\hline$\sum n \log _{2} n$ & \multicolumn{2}{|c|}{311.81} & \multicolumn{2}{|c|}{324.91} & \multicolumn{2}{|c|}{301.28} \\
\hline I & \multicolumn{2}{|c|}{3.39} & \multicolumn{2}{|c|}{3.42} & \multicolumn{2}{|c|}{3.34} \\
\hline $\mathrm{H}$ & \multicolumn{2}{|c|}{3.13} & \multicolumn{2}{|c|}{3.15} & \multicolumn{2}{|c|}{3.15} \\
\hline EWQI & \multicolumn{2}{|c|}{0.92} & \multicolumn{2}{|c|}{0.92} & \multicolumn{2}{|c|}{0.94} \\
\hline $\mathrm{M}=\sum \mathrm{m}$ & \multicolumn{2}{|c|}{38.2} & \multicolumn{2}{|c|}{36.6} & \multicolumn{2}{|c|}{33.2} \\
\hline$\sum \log _{2} \mathrm{M}$ & \multicolumn{2}{|c|}{5.25} & \multicolumn{2}{|c|}{5.190} & \multicolumn{2}{|c|}{5.05} \\
\hline AWQI & \multicolumn{2}{|c|}{1.445} & \multicolumn{2}{|c|}{1.439} & \multicolumn{2}{|c|}{1.445} \\
\hline
\end{tabular}


Table 3.20.

Entropic and Armenian Water Quality Indexes for River Kasakh (2009).

\begin{tabular}{|c|c|c|c|c|c|c|c|c|c|c|}
\hline \multirow{3}{*}{ Parameters } & \multicolumn{10}{|c|}{ Sampling points } \\
\hline & \multicolumn{2}{|r|}{43} & \multicolumn{2}{|r|}{44} & \multicolumn{2}{|r|}{45} & \multicolumn{2}{|r|}{46} & \multicolumn{2}{|r|}{47} \\
\hline & $\mathrm{n}$ & $\operatorname{lng}_{2} n$ & $\mathbf{n}$ & nlog $n$ & $\mathrm{n}$ & $n \log _{2} n$ & $\mathbf{n}$ & $n \log _{2} n$ & $\mathbf{n}$ & $n \log _{2} n$ \\
\hline $\mathrm{BOD}_{5}$ & 3 & 4.75 & 4 & 8 & 0 & 0 & 0 & 0 & 0 & 0 \\
\hline $\mathrm{NO}_{2}^{-}$ & 0 & 0 & 4 & 8 & 0 & 0 & 0 & 0 & 0 & 0 \\
\hline $\mathrm{NH}_{4}^{+}$ & 0 & 0 & 6 & 15.5 & 0 & 0 & 0 & 0 & 0 & 0 \\
\hline $\mathrm{Al}$ & 6 & 15.5 & 6 & 15.5 & 5 & 11.61 & 4 & 8 & 6 & 15.5 \\
\hline V & 5 & 11.61 & 6 & 15.5 & 9 & 28.5 & 9 & 28.5 & 6 & 15.5 \\
\hline $\mathrm{Cu}$ & 6 & 15.5 & 5 & 11.61 & 0 & 0 & 0 & 0 & 5 & 11.61 \\
\hline $\mathrm{Cr}$ & 0 & 0 & 0 & 0 & 3 & 4.75 & 4 & 8 & 6 & 15.5 \\
\hline $\mathrm{Mn}$ & 6 & 15.5 & 6 & 15.5 & 0 & 0 & 0 & 0 & 0 & 0 \\
\hline $\mathrm{N}$ & & 23 & & 37 & & 17 & & 17 & & 23 \\
\hline$\sum n \log _{2} n$ & & 52.51 & & 39.61 & & 44.87 & & 44.5 & & 58.11 \\
\hline I & & 2.72 & & 2.42 & & 2.64 & & 2.61 & & 2.52 \\
\hline $\mathrm{H}$ & & 1.77 & & 2.79 & & 1.45 & & 1.48 & & 2.00 \\
\hline EWQI & & .651 & & 1.153 & & 0,549 & & .567 & & 0.794 \\
\hline $\mathrm{M}=\sum \mathrm{m}$ & & 17 & & 19.7 & & 15.5 & & 15.9 & & 13.4 \\
\hline $\log _{2} M$ & & 4.085 & & 4.30 & & 3.95 & & 3.99 & & 3.74 \\
\hline AWQI & & 1.055 & & 1.583 & & 0.944 & & .966 & & 1.168 \\
\hline
\end{tabular}

Table 3.21

Water Quality Indexes for Rivers Sevdjur, Kasakh and Aparan (2009).

\begin{tabular}{|c|c|c|c|c|c|}
\hline $\begin{array}{c}\text { Sampling } \\
\text { points }\end{array}$ & EWQI & AWQI & WCI & CWQI & SCWQI \\
\hline 40 & 0.92 & 1.445 & 3.91 & 64.01 & 2.96 \\
\hline 41 & 0.92 & 1.439 & 3.41 & 65.09 & 2.83 \\
\hline 42 & 0.94 & 1.445 & 4.03 & 64.25 & 3.28 \\
\hline 43 & 0.651 & 1.055 & 1.21 & 71.18 & 1.81 \\
\hline 44 & 1.153 & 1.583 & 2.25 & 65.63 & 1.95 \\
\hline 45 & 0.549 & 0.944 & 1.43 & 74.65 & 1.45 \\
\hline 46 & 0.567 & 0.966 & 1.43 & 72.68 & 1.58 \\
\hline 47 & 0.794 & 1.168 & 2.1 & 69.77 & 1.98 \\
\hline 111 & 0.693 & 0.973 & 1.18 & 78.55 & 1.56 \\
\hline
\end{tabular}


With the help of a computer program «Origin-6» made an analysis of the linear relationship between AWQI and drugimy water quality index (WQI) [106].

$$
\mathrm{AWQI}=\mathrm{A}+\mathrm{B} \cdot[\mathrm{WQI}]
$$

Table 3.22.

Coefficient of correlation.

\begin{tabular}{|c|c|c|c|c|}
\hline WQI & $\mathbf{A} \pm \mathbf{a}$ & $\mathbf{B} \pm \mathbf{b}$ & $\boldsymbol{R}$ & $\boldsymbol{N}$ \\
\hline \multicolumn{5}{|c|}{ Sevjur } \\
\hline WCI & $1.404 \pm 0.007$ & $0.010 \pm 0.002$ & 0.98321 & 3 \\
\hline SCWQI & $1.410 \pm 0.031$ & $0.011 \pm 0.010$ & 0.72297 & 3 \\
\hline EWQI & $0.416 \pm 0.288$ & $2.014 \pm 0.306$ & 0.90131 & 12 \\
\hline CWQI & $1.828 \pm 0.083$ & $-0.006 \pm 0.001$ & 0.97736 & 3 \\
\hline \multicolumn{5}{|c|}{ Kasakh } \\
\hline WCI & $0.355 \pm 0.321$ & $0.468 \pm 0.185$ & 0.82497 & 5 \\
\hline SCWQI & $0.309 \pm 0.777$ & $0.828 \pm 0.440$ & 0,73536 & 5 \\
\hline EWQI & $0.365 \pm 0.029$ & $1.047 \pm 0.038$ & 0.99806 & 5 \\
\hline CWQI & $6.392 \pm 0.813$ & $-0.074 \pm 0.011$ & 0.96587 & 5 \\
\hline \multicolumn{5}{|c|}{ Sevjur. Kasakh and Aparan } \\
\hline WCI & $0.814 \pm 0.125$ & $0.176 \pm 0.055$ & 0.80874 & 9 \\
\hline SCWQI & $0.613 \pm 0.202$ & $0.284 \pm 0.089$ & 0.76632 & 9 \\
\hline EWQI & $0.256 \pm 0.104$ & $1.212 \pm 0.127$ & 0.96394 & 9 \\
\hline CWQI & $4.331 \pm 0.528$ & $-0.045 \pm 0.007$ & 0.91235 & 9 \\
\hline
\end{tabular}

\subsubsection{River Hrazdan}

Table 3.23.

Entropic and Armenian Water Quality Indexes for River Hrazdan

(2009).

\begin{tabular}{|c|c|c|c|c|c|c|c|c|c|c|c|}
\hline \multirow{2}{*}{ Indicator } & \multicolumn{10}{c|}{ Smpling points } \\
\cline { 2 - 12 } & $\mathbf{5 2}$ & \multicolumn{2}{|c|}{$\mathbf{5 3}$} & \multicolumn{2}{|c|}{$\mathbf{5 4}$} & \multicolumn{2}{|c|}{$\mathbf{5 5}$} & \multicolumn{2}{|c|}{$\mathbf{5 6}$} \\
\cline { 2 - 12 } & $\mathbf{n}$ & $\mathbf{n} \log _{2} \mathbf{n}$ & $\mathbf{n}$ & $\mathbf{n} \log _{2} \mathbf{n}$ & $\mathbf{n}$ & $\mathbf{n} \log _{2} \mathbf{n}$ & $\mathbf{n}$ & $\mathbf{n} \log _{2} \mathbf{n}$ & $\mathbf{n}$ & $\mathbf{n} \log _{2} \mathbf{n}$ \\
\hline $\mathrm{BOD}_{5}$ & 7 & 19.64 & 0 & 0 & 0 & 0 & 12 & 43 & 5 & 11.61 \\
\hline $\mathrm{COD}$ & 0 & 0 & 0 & 0 & 0 & 0 & 8 & 24 & 5 & 11.61 \\
\hline $\mathrm{NO}_{2}^{-}$ & 0 & 0 & 0 & 0 & 0 & 0 & 12 & 43 & 12 & 43 \\
\hline $\mathrm{NH}_{4}^{+}$ & 0 & 0 & 0 & 0 & 0 & 0 & 12 & 43 & 12 & 43 \\
\hline $\mathrm{SO}_{4}^{-2}$ & 0 & 0 & 0 & 0 & 0 & 0 & 0 & 0 & 7 & 19.64 \\
\hline
\end{tabular}




\begin{tabular}{|c|c|c|c|c|c|c|c|c|c|c|}
\hline \multirow[t]{3}{*}{ Indicator } & \multicolumn{10}{|c|}{ Smpling points } \\
\hline & \multicolumn{2}{|r|}{52} & \multicolumn{2}{|c|}{53} & \multicolumn{2}{|c|}{54} & \multicolumn{2}{|c|}{55} & \multicolumn{2}{|c|}{56} \\
\hline & \begin{tabular}{|l|}
$\mathbf{n}$ \\
\end{tabular} & $\mathbf{n}$ & $n \log _{2} n$ & $\mathbf{n}$ & $\operatorname{nn} \log _{2} n$ & $\mathbf{n}$ & $\log _{2} n$ & $\mathbf{n}$ & $\operatorname{nlog} 2 n$ & $\mathbf{n}$ \\
\hline $\mathrm{Al}$ & 9 & 28.5 & 9 & 28.5 & 9 & 28.5 & 7 & 19.64 & 8 & 24 \\
\hline $\mathrm{V}$ & 11 & 38 & 12 & 43 & 12 & 43 & 12 & 43 & 12 & 43 \\
\hline $\mathrm{Cu}$ & 7 & 19.64 & 10 & 33.2 & 8 & 24 & 11 & 38 & 11 & 38 \\
\hline $\mathrm{Cr}$ & 6 & 15.5 & 8 & 24 & 9 & 28.5 & 10 & 33.2 & 11 & 38 \\
\hline $\mathrm{Mn}$ & 8 & 24 & 8 & 24 & 10 & 33.2 & 12 & 43 & 12 & 43 \\
\hline $\mathrm{Se}$ & 0 & 0 & 0 & 0 & 0 & 0 & 0 & 0 & 7 & 19.64 \\
\hline $\mathrm{N}$ & & 48 & 4 & & 48 & & 9 & & 10 & 2 \\
\hline$\sum n \log _{2} \mathrm{n}$ & & 45.28 & 152 & & 157 & & 329 & .82 & 33 & 4.5 \\
\hline $\mathrm{I}$ & & 3,02 & 3.2 & & 3.2 & & 3. & & 3.2 & 28 \\
\hline $\mathrm{H}$ & & 2.56 & 2.3 & & 2.3 & & 3. & & 3.3 & 32 \\
\hline EWQI & & .848 & 0,7 & & 0,7 & & 0.9 & & 1.0 & 33 \\
\hline $\mathrm{M}=\sum \mathrm{m}$ & & 19.1 & 19 & & 23 & & 10 & & 45 & .3 \\
\hline $\log _{2} M$ & & .253 & 4.2 & & 4.5 & & 6.6 & & 5.4 & \\
\hline AWQI & & .273 & 1.1 & & 1.1 & & 1.5 & & 1.5 & \\
\hline
\end{tabular}

Table 3.24.

Water Quality Indexes for River Hrazdan (2009).

\begin{tabular}{|c|c|c|c|c|c|}
\hline $\begin{array}{c}\text { Smpling } \\
\text { points }\end{array}$ & EWQI & AWQI & WCI & CWQI & SCWQI \\
\hline 51 & 0.936 & 1.292 & 1.34 & 71.24 & 1.63 \\
\hline 52 & 0.848 & 1.273 & 2.77 & 67.71 & 2.66 \\
\hline 53 & 0.708 & 1.136 & 2.39 & 65.12 & 2.89 \\
\hline 54 & 0.708 & 1.160 & 2.69 & 62.52 & 2.54 \\
\hline 55 & 0.913 & 1.583 & 4.67 & 45.23 & 3.17 \\
\hline 56 & 1.033 & 1.583 & 5.18 & 55.31 & 3.01 \\
\hline 57 & 0.303 & 0.415 & 0.99 & 90.15 & 0.69 \\
\hline 58 & 0.793 & 1.213 & 1.48 & 72.74 & 1.89 \\
\hline 59 & 0.798 & 1.340 & 6.37 & 57.53 & 2.82 \\
\hline
\end{tabular}

Analysis of obtained data [107] indicate that AWQI has liner dependence with WCI, SCWQI, EWQI and an inverse dependence with CWQI: 
Table 3.25.

Entropic and Armenian Water Quality Indexes for River Hrazdan

(2009).

\begin{tabular}{|c|c|c|c|c|c|c|c|c|c|c|}
\hline \multirow[t]{3}{*}{ Indicator } & \multicolumn{10}{|c|}{ Smpling points } \\
\hline & \multicolumn{2}{|r|}{51} & \multicolumn{2}{|r|}{57} & \multicolumn{2}{|r|}{58} & \multicolumn{2}{|r|}{59} & \multicolumn{2}{|r|}{56} \\
\hline & $\mathbf{n}$ & $n \log _{2} n$ & $\mathbf{n}$ & $n \log _{2} n$ & $\bar{n}$ & $n \log _{2} n$ & $\mathbf{n}$ & $\log _{2} n$ & $\mathbf{n}$ & $n \log _{2} n$ \\
\hline $\mathrm{BOD}_{5}$ & 0 & 0 & 0 & 0 & 0 & 0 & 0 & 0 & 5 & 11.61 \\
\hline COD & 0 & 0 & 0 & 0 & 7 & 19.64 & 7 & 19.64 & 5 & 11.61 \\
\hline $\mathrm{NO}_{2}^{-}$ & 0 & 0 & 0 & 0 & 0 & 0 & 12 & 43 & 12 & 43 \\
\hline $\mathrm{NH}_{4}^{+}$ & 0 & 0 & 0 & 0 & 3 & 4.75 & 12 & 43 & 12 & 43 \\
\hline $\mathrm{Al}$ & 0 & 0 & 6 & 15.51 & 11 & 38 & 1 & 0 & 8 & 24 \\
\hline $\mathrm{V}$ & 5 & 11.61 & 0 & 0 & 9 & 28.5 & 12 & 43 & 12 & 43 \\
\hline $\mathrm{Cu}$ & 0 & 0 & 6 & 15.51 & 10 & 33.2 & 4 & 8 & & \\
\hline $\mathrm{Mn}$ & 0 & 0 & 0 & 0 & 10 & 33.2 & 0 & 0 & & \\
\hline $\mathrm{Cr}$ & 3 & 4.75 & 0 & 0 & 0 & 0 & 9 & 28.5 & 11 & 38 \\
\hline $\mathrm{Br}$ & 5 & 11.61 & 0 & 0 & 0 & 0 & 0 & 0 & 12 & 43 \\
\hline $\mathrm{Se}$ & 4 & 8 & 0 & 0 & 0 & 0 & 0 & 0 & 7 & 19.64 \\
\hline $\mathrm{N}$ & & 17 & & 12 & & 50 & & 57 & & 102 \\
\hline$\sum \operatorname{nlog}_{2} \mathrm{n}$ & & 35.97 & & 31 & & 57.29 & & 85.14 & & 34.5 \\
\hline I & & 2.11 & & 2.583 & & 3.146 & & .248 & & 3.28 \\
\hline $\mathrm{H}$ & & 1.97 & & 2.30 & & 2.494 & & .581 & & 3.32 \\
\hline EWQI & & 0.936 & & 0,708 & & 0,793 & & .798 & & .033 \\
\hline $\mathrm{M}=\sum \mathrm{m}$ & & 11.8 & & 19.4 & & 18.8 & & 43 & & 45.3 \\
\hline $\log _{2} M$ & & 3.558 & & 4.276 & & 4.230 & & .423 & & .498 \\
\hline AWQI & & 1.292 & & 1.136 & & 1.216 & & .340 & & .583 \\
\hline
\end{tabular}

$$
\begin{gathered}
\mathrm{AWQI}=(0.976 \pm 0.129)+(0.114 \pm 0.037) \cdot \mathrm{WCI} \\
\mathrm{R}^{2}=0.83405, \mathrm{~N}=6 \\
\mathrm{AWQI}=(0.929 \pm 0.443)+(0.154 \pm 0.164) \cdot \mathrm{SCWQI} \\
\mathrm{R}^{2}=0.42510, \mathrm{~N}=6 \\
\mathrm{AWQI}=(0.221 \pm 0.349)+(1.302 \pm 0.403) \cdot \mathrm{EWQI} \\
\mathrm{R}^{2}=0.85004, \mathrm{~N}=6
\end{gathered}
$$




$$
\begin{gathered}
\text { AWQI }=(2.235 \pm 0.415)-(0.016 \pm 0.007) \cdot \mathrm{CWQI} \\
\mathrm{R}^{2}=0.7682, \mathrm{~N}=6: \\
\mathrm{AWQI}=(0.855 \pm 0.187)+(0.118 \pm 0.052) \cdot \mathrm{WCI} \\
\mathrm{R}^{2}=0.64967, \mathrm{~N}=9 \\
\text { AWQI }=(0.389 \pm 0.224)+(0.356 \pm 0.090) \cdot \mathrm{SCWQI} \\
\mathrm{R}^{2}=0.82769, \mathrm{~N}=9 \\
\text { AWQI }=(0.014 \pm 0.140)+(1.579 \pm 0.174) \cdot \mathrm{EWQI} \\
\mathrm{R}^{2}=0.96023, \mathrm{~N}=9 \\
\text { AWQI }=(2.805 \pm 0.304)-(0.024 \pm 0.005) \cdot \mathrm{CWQI} \\
\mathrm{R}^{2}=0.89455, \mathrm{~N}=9:
\end{gathered}
$$

\subsubsection{Lake Sevan}

Lake Sevan is located at an altitude of $1900 \mathrm{~m}$; The area is $1240 \mathrm{~km}^{2}\left(1360 \mathrm{~km}^{2}\right.$ before the level is lowered). The area of the Sevan catchment area is 4.7 thousand $\mathrm{km}^{2} .28$ rivers flow into the lake, the largest of which reaches a length of $50 \mathrm{~km}$. From Sevan flows only one river - Hrazdan, flowing into the Araks. Lake Sevan - freshwater, the water surface has azure blue. The mineralization of water is about $700 \mathrm{mg} / \mathrm{l}$, the dry residue is 0.5 $\mathrm{g} / \mathrm{l}$. Lake is a tectonic barren nature. The same name of the basin is of tectonic origin, and the dam was formed due to the outflow of the Holocene lavas. Sevan is surrounded by mountain ranges: from the north Pambak and Areguni, from the north-east by Sevan, from the west by Gegham, and from the south by the Vardenis. Shorzhinsky underwater shaft-threshold, Artanishsky peninsula and Noratus crook entering the lake, Sevan is divided into two parts: Small and Big Sevan. Small Sevan is very deep up to $83 \mathrm{~m}$ and rugged banks. It is in this part that the greater volume of lake water is concentrated. In the Greater Sevan the 
bottom is level, the banks are not very rugged, the depth does not exceed 30 meters [27] .

There are 26 stations on the Lake Sevan (monitoring posts), from No. 115 to No. 119, also 130 and 131 are located in the small Sevan and from No. 120 to 129 in the big Sevan [14].

Table 3.26.

Water quality indices of Lake Sevan 2009.

\begin{tabular}{|c|c|c|c|c|c|}
\hline Sampling points & EWQI & AWQI & WCI & CWQI & SCWQI \\
\hline 116 & 0.811 & 1.181 & 1.41 & 70.37 & 1.65 \\
\hline 117 & 0.826 & 1.207 & 1.42 & 70.95 & 1.56 \\
\hline $117^{\prime}{ }^{*}$ & 0.831 & 1.201 & 1.43 & 70.21 & 1.81 \\
\hline 118 & 0.867 & 1.276 & 1.87 & 65.98 & 1.88 \\
\hline 119 & 0.847 & 1.228 & 1.48 & 69.12 & 1.81 \\
\hline $119^{\prime}$ & 0.923 & 1.334 & 1.90 & 66.35 & 2.11 \\
\hline 120 & 0.939 & 1.340 & 1.67 & 67.24 & 1.65 \\
\hline $12{ }^{\prime}$ & 0.921 & 1.332 & 1.92 & 65.50 & 1.96 \\
\hline 121 & 0.803 & 1.187 & 1.60 & 66.79 & 1.94 \\
\hline $121^{\prime}$ & 0.799 & 1.192 & 1.56 & 66.89 & 1.83 \\
\hline 122 & 0.820 & 1.204 & 1.50 & 66.65 & 2.19 \\
\hline $122^{\prime}$ & 0.820 & 1.214 & 1.49 & 68.68 & 1.59 \\
\hline 123 & 0.811 & 1.205 & 1.50 & 67.05 & 1.69 \\
\hline $123^{\prime}$ & 0.819 & 1.212 & 1.55 & 66.58 & 1.75 \\
\hline 124 & 0.819 & 1.212 & 1.53 & 68.16 & 1.85 \\
\hline 125 & 0.819 & 1.222 & 1.52 & 66.49 & 1.59 \\
\hline 126 & 0.825 & 1.229 & 1.54 & 67.27 & 1.82 \\
\hline 127 & 0.833 & 1.237 & 1.55 & 67.14 & 1.78 \\
\hline 128 & 0.883 & 1.3117 & 1.75 & 66.02 & 2.11 \\
\hline $128^{\prime}$ & 0.825 & 1.209 & 1.44 & 68.25 & 2.03 \\
\hline 129 & 0.815 & 1.198 & 1.44 & 67.60 & 1.93 \\
\hline $129^{\prime}$ & 0.815 & 1.198 & 1.52 & 67.96 & 1.79 \\
\hline 130 & 0.825 & 1.209 & 1.43 & 68.64 & 1.63 \\
\hline 131 & 0.834 & 1.217 & 1.43 & 68.48 & 1.88 \\
\hline $131^{\prime}$ & 0.825 & 1.208 & 1.46 & 68.45 & 1.95 \\
\hline
\end{tabular}

*- sampling point located at $20 \mathrm{~m}$ depth 
Analysis of obtained data [108] indicate that AWQI has liner dependence with WCI, SCWQI, EWQI and an inverse dependence with CWQI.

$$
\begin{gathered}
\text { AWQI }=(0.739 \pm 0.074)+(0.313 \pm 0.047) \cdot \mathrm{WCI} \\
\mathrm{R}^{2}=0.80233, \mathrm{~N}=26 \\
\text { AWQI }=(1.047 \pm 0.127)+(0.096 \pm 0.069) \cdot \mathrm{SCWQI} \\
\mathrm{R}^{2}=0.27301, \mathrm{~N}=26 \\
\mathrm{AWQI}=(0.203 \pm 0.038)+(1.225 \pm 0.046) \cdot \mathrm{EWQI} \\
\mathrm{R}^{2}=0.98339, \mathrm{~N}=26 \\
\text { AWQI }=(2.637 \pm 0.513)-(0.021 \pm 0.008) \cdot \mathrm{CWQI} \\
\mathrm{R}^{2}=0.49061, \mathrm{~N}=26
\end{gathered}
$$

\subsubsection{The ecological status of reservoirs in Armenia}

The purpose of this article is to assess the water quality of the reservoirs of Lake Arpi, Lake Yerevan, Akhurian, Azat, Aparan and Kechut using the Armenian Water Quality Index.

About 74 reservoirs with total volume of 988 million $\mathrm{m}^{3}$ are concentrated in Armenia today. The largest reservoir in the territory of Armenia is Akhurian reservoir with a volume of 525 million $\mathrm{m}^{3}$. The volume and spilway heighr resetvuars are shown in Table 3.27.

Table 3.27.

The volume fnd spilway heighr for reservuars.

\begin{tabular}{|c|c|c|c|}
\hline $\begin{array}{c}\text { Name of } \\
\text { reservoir }\end{array}$ & Region & $\begin{array}{c}\text { Volume (per } \\
\text { million } \mathbf{~ m}^{\mathbf{3}} \text { ) }\end{array}$ & $\begin{array}{c}\text { Spillway Height } \\
(\mathbf{m})\end{array}$ \\
\hline Akhuryan & Shirak & 525 & 59.1 \\
\hline Lake Arpi & Shirak & 105 & 15 \\
\hline Aparan & Aragatsotn & 91 & 52.6 \\
\hline Azat & Ararat & 70 & 76 \\
\hline Kechut & Syunik & 23 & 20 \\
\hline Lake Yerevan & Yerevan & 5 & 18 \\
\hline
\end{tabular}


Akhurian Reservoir is a reservoir on the Akhurian River between Armenia and Turkey. The reservoir has a surface area of $54 \mathrm{~km}^{2}$, max long $20 \mathrm{~km}$. It is one of the largest reservoirs in the Caucasus. Coordinates $40^{\circ} 33^{\prime} 47.67^{\prime \prime N} 43^{\circ} 39^{\prime} 16.26 " E$. Lake Arpi is situated in the north-west of the Republic of Armenia. The lake is fed by meltwater and four streams, and it is the source of the Akhurian River. Being alpine specific ecosystem with its rare flora and fauna it ensures ecological balance of adjacent extensive area. The reservoir-lake spans $7.3 \mathrm{~km}$ long and $4.3 \mathrm{~km}$ wide, with an area of $20 \mathrm{~km}^{2}$.Coordinates $41^{\circ} 03^{\prime} 0{ }^{\prime \prime} \mathrm{N}$ $43^{\circ} 37^{\prime} 00$ "E. Yerevan Lake is an artificial reservoir located in the capital of Armenia in Yerevan. The reservoir-lake Yerevan spans $7.3 \mathrm{~km}$ long and $5.0 \mathrm{~km}$ wide, with an area of $0.65 \mathrm{~km}^{2}$. Coordinates $40^{\circ} 9^{\prime} 35.04 " \mathrm{~N} 44^{\circ} 28^{\prime} 36.54^{\prime \prime} \mathrm{E}$. Aparan Reservoir is a reservoir in Armenia, in the Aragatsotn region. Built on the river Kassah. Area of $7.9 \mathrm{~km}^{2}$. Used for irrigation. Coordinates $40^{\circ} 29^{\prime} 49^{\prime \prime} \mathrm{N} 44^{\circ} 26^{\prime} 07^{\prime \prime E}$. Ketchut Reservoir is a reservoir in the Vayots Dzor region of Armenia, on the river Arpa, $3.5 \mathrm{~km}$ south of the resort town of Jermuk. The reservoir was built in 1981 . Water from it through the conduit enters Lake Sevan to regulate the level. Coordinates $39^{\circ} 47^{\prime} 54^{\prime \prime} \mathrm{N} 45^{\circ} 39^{\prime} 22^{\prime \prime} \mathrm{E}$. Azat Reservoir is a reservoir located in Armenia, in the Ararat region, above the village of Lanjazat, at an altitude of $1050 \mathrm{~m}$ above sea level. The reservoir was built on the Azat River. The volume of the lake is 70 million $\mathrm{m}^{3}$. Water is used to irrigate the Ararat Plain. Coordinates $40^{\circ} 04^{\prime} 00^{\prime \prime} \mathrm{N} 44^{\circ} 36^{\prime} 00^{\prime \prime} \mathrm{E}$. 


\section{Reservoirs Lake Arpi, Akhuryan and Lake \\ Yerevan}

It was established in the rezervoirs Lake Arpi, Lake Yerevan and Akhuryan water is regularly increased MAC of nitrite ions, ammonium ion, copper, vanadium, aluminum, chrom, manganese and iron.

Table 3.28.

EWQI and AWQI indexes for reservoirs Lake Arpi, Akhuryan and Lake Yerevan.

\begin{tabular}{|c|c|c|c|c|c|c|}
\hline \multirow{3}{*}{$\begin{array}{l}\text { Parameters and } \\
\text { Indicators }\end{array}$} & \multicolumn{4}{|c|}{ Lake Arpi Akhuryan } & \multirow{2}{*}{\multicolumn{2}{|c|}{$\frac{\text { Lake Yerevan }}{112}$}} \\
\hline & \multicolumn{2}{|c|}{109} & \multicolumn{2}{|r|}{110} & & \\
\hline & $n$ & $n \log _{2} n$ & $n$ & $n \log _{2} n$ & $n$ & $n \log _{2} n$ \\
\hline $\mathrm{NO}_{2}^{-}$ & 0 & 0 & 4 & 8 & 12 & 43.0 \\
\hline $\mathrm{NH}_{4}^{+}$ & 0 & 0 & 0 & 0 & 10 & 33.2 \\
\hline $\mathrm{DOD}_{5}$ & 0 & 0 & 0 & 0 & 6 & 15.5 \\
\hline $\mathrm{Al}$ & 6 & 15.5 & 3 & 4.75 & 7 & 19.64 \\
\hline $\mathrm{V}$ & 6 & 15.5 & 7 & 19.64 & 12 & 43.0 \\
\hline $\mathrm{Cu}$ & 6 & 15.5 & 6 & 15.5 & 10 & 33.2 \\
\hline $\mathrm{Mn}$ & 5 & 11.6 & 0 & 0 & 0 & 0 \\
\hline $\mathrm{Fe}$ & 4 & 8 & 0 & 0 & 0 & 0 \\
\hline $\mathrm{Cr}$ & 2 & 2 & 0 & 0 & 0 & 0 \\
\hline $\mathrm{Se}$ & 0 & 0 & 0 & 0 & 6 & 15.5 \\
\hline $\mathrm{N}$ & \multicolumn{2}{|c|}{29} & \multicolumn{2}{|r|}{20} & \multicolumn{2}{|r|}{63} \\
\hline$\sum n \log _{2} n$ & \multicolumn{2}{|c|}{68.1} & \multirow{2}{*}{\multicolumn{2}{|c|}{$\begin{array}{l}47.9 \\
205\end{array}$}} & \multicolumn{2}{|c|}{203.04} \\
\hline I & \multirow{2}{*}{\multicolumn{2}{|c|}{$\frac{2.348}{2.507}$}} & & & & 3,22 \\
\hline $\mathrm{H}$ & & & \multicolumn{2}{|c|}{1.924} & \multicolumn{2}{|c|}{2.75} \\
\hline EWQI & \multicolumn{2}{|c|}{1.068} & \multicolumn{2}{|c|}{0.8035} & \multicolumn{2}{|c|}{0.855} \\
\hline $\mathrm{M}=\Sigma \mathrm{m}$ & \multicolumn{2}{|c|}{35.5} & \multicolumn{2}{|r|}{13.2} & \multicolumn{2}{|c|}{36.3} \\
\hline $\log _{2} M$ & \multirow{2}{*}{\multicolumn{2}{|c|}{$\begin{array}{c}5.14 \\
1582\end{array}$}} & \multirow{2}{*}{\multicolumn{2}{|c|}{$\begin{array}{c}3.72 \\
1.1755\end{array}$}} & \multirow{2}{*}{\multicolumn{2}{|c|}{$\begin{array}{l}5.180 \\
1.373\end{array}$}} \\
\hline AWQI & & & & & & \\
\hline
\end{tabular}

For example, in rezervoir Lake Arpi $\mathrm{Al}, \mathrm{V}, \mathrm{Cu}, \mathrm{Mn}, \mathrm{Fe}$ and Cr number of MAC increasing cases are 6, 6, 6, 5, 4 and 2 times, respectively. The amount of excess cases of MAC $-N=20$, $\sum n \log _{2} n=47.9, I=47.9 / 20=2.395, H=\log _{2} 20-2.395=$ 
$4.319-2.395=1.924, \mathrm{EWQI}=G=1.924 / 2.395=0.8035$. The total amount of the multiplicity of MAC exceedances - $\mathrm{M}=$ $\sum \mathrm{m}=13.2, \log _{2} \mathrm{M}=3.72$, EWQI $=0.8035+0.372=1.1755$. The values of the indices EWQI and AWQI are given in Table 3.28.

Reservoirs Aparan, Azat and Kechut

Table 3.29.

EWQI and AWQ I indexes for reservoirs Aparan, Azat and Lake Kechut.

\begin{tabular}{|c|c|c|c|c|c|c|}
\hline \multirow{3}{*}{$\begin{array}{l}\text { Parameters and } \\
\text { Indicators }\end{array}$} & \multicolumn{4}{|c|}{ Aparan Azat } & \multirow{2}{*}{\multicolumn{2}{|c|}{ Kechut }} \\
\hline & \multicolumn{2}{|r|}{111} & \multicolumn{2}{|c|}{113} & & 114 \\
\hline & $n$ & $n \log _{2} n$ & $n$ & $n \log _{2} n$ & $n$ & $n \log _{2} n$ \\
\hline $\mathrm{NO}_{2}^{-}$ & 1 & 0 & 0 & 0 & 0 & 0 \\
\hline $\mathrm{Al}$ & 4 & 8 & 2 & 2 & 10 & 33.2 \\
\hline $\mathrm{V}$ & 5 & 11.6 & 7 & 19.64 & 10 & 33.2 \\
\hline $\mathrm{Cu}$ & 0 & 0 & 2 & 2 & 0 & 0 \\
\hline $\mathrm{N}$ & \multicolumn{2}{|r|}{10} & \multicolumn{2}{|c|}{11} & \multicolumn{2}{|r|}{20} \\
\hline$\sum n \log _{2} n$ & \multicolumn{2}{|r|}{19.6} & \multirow{2}{*}{\multicolumn{2}{|c|}{$\frac{23.64}{215}$}} & \multicolumn{2}{|r|}{66.4} \\
\hline I & \multirow{2}{*}{\multicolumn{2}{|c|}{$\frac{1.96}{1.36}$}} & & & \multirow{2}{*}{\multicolumn{2}{|c|}{$\frac{3.32}{1.0}$}} \\
\hline $\mathrm{H}$ & & & \multicolumn{2}{|c|}{$\begin{array}{l}2.15 \\
131\end{array}$} & & \\
\hline EWQI & \multicolumn{2}{|r|}{0.693} & \multicolumn{2}{|c|}{0.608} & \multicolumn{2}{|c|}{0.301} \\
\hline $\mathrm{M}=\Sigma \mathrm{m}$ & \multicolumn{2}{|r|}{7.2} & \multicolumn{2}{|c|}{11.7} & \multicolumn{2}{|r|}{6.7} \\
\hline $\log _{2} M$ & \multicolumn{2}{|c|}{2.846} & & \multicolumn{2}{|c|}{2.742} \\
\hline AWQI & \multicolumn{2}{|c|}{0.978} & \multicolumn{2}{|c|}{$\frac{3.546}{0.963}$} & \multicolumn{2}{|c|}{$\frac{2.742}{0.575}$} \\
\hline
\end{tabular}

It was established in the rezervoirs Aparan, Azat and Kechut water is regularly increased MAC of copper, vanadium and aluminum. Calculations and values of the EWQI and AWQI indices are given in Table 3.29.

The quality of reservoirs Lake Arpi, Lake Yerevan, Akhuryan, Azat, Aparan and ketchut water also comprehensively evaluated by other indexes: WCI, CWQI, SCWQI. Values of the WQI indices are given in Table 3.30 [109-122]. 
Table 3.30.

WQI for the reservoirs.

\begin{tabular}{|c|c|c|c|c|c|}
\hline Reservoirs & AWQI & EWQI & WCI & CWQI & SCWQI \\
\hline Lake Arpi & 1.5826 & 1.068 & 2.11 & 69.29 & 2.04 \\
\hline Lake Yerevan & 1.373 & 0.855 & 5.11 & 53.8 & 3.49 \\
\hline Akhuryan & 1.1755 & 0.8035 & 2.24 & 72.84 & 2.09 \\
\hline Aparan & 0.978 & 0.693 & 1.18 & 78.55 & 1.56 \\
\hline Azat & 0.963 & 0.608 & 1.94 & 81.87 & 1.42 \\
\hline Ketchut & 0.575 & 0.301 & 1.22 & 80.68 & 1.9 \\
\hline
\end{tabular}

According to WQI values, the water quality in the Aparansky, Azatsky and Kechutsky reservoirs is good from the 1 st excellent class to the 2 nd, good grade. The water quality of the reservoirs of Akhuryan, Lake Arpi and in Yerevan Lake, on the contrary, is poor from 3rd to 2nd poor class, and restricts the use of water for irrigation purposes. Poor water quality of the Lake Arpi reservoir is associated with an increase in the amount of metals. Reduced water quality of the Akhuryan reservoir and lake Yerevan is associated with pollution of the main settlements in the river basin, respectively, in Gyumri and Yerevan, with municipal wastewater. As a result of pollution of domestic wastewater, river water increases with the content of nitrite and ammonium nitrogen, $\mathrm{BOD}_{5}$ and has an oxygen deficiency.

With the help of the computer program 'Origin-6' is done an analysis of the linear relationship between AWQI and other WQI: AWQI $=a+b$ (WQI).

$$
\begin{gathered}
\mathrm{AWQI}=(0,797 \pm 0,268)+(0,136 \pm 0,101) \cdot \mathrm{WCI} ; \\
R^{2}=0,55911 ; N=6 ; \\
\mathrm{AWQI}=(0,635 \pm 0,461)+(0,226 \pm 0,210) \cdot \mathrm{SCWQI} ; \\
R^{2}=0,47329 ; N=6 ;
\end{gathered}
$$




$$
\begin{gathered}
\mathrm{AWQI}=(0,139 \pm 0,092)+(1.342 \pm 0,121) \cdot \mathrm{EWQI} ; \\
R^{2}=0,984100 ; N=6 ; \\
\mathrm{AWQI}=(2.825 \pm 0.881)-(0.024 \pm 0,012) \cdot \mathrm{CWQI} ; \\
R^{2}=0,70105 ; N=6 .
\end{gathered}
$$

Thus, a correlation between AWQI and other WQI is established. Analysis of obtained data [92, 94, 106, 109-111] indicates that AWQI has liner dependence on WCI, SCWQI, EWQI and an inverse dependence on CWQI. This results from the fact that the scale of the Canadian index of quality of water begins with 100, and scales of indexes of impurity of water, EWQI, WQI and SCWQI of water start from scratch.

\subsection{Method on Integrated assessment of Natural Water Quality}

New method of integrated assessment of natural water quality has been developed which complements the requirements of the EU WFD and the complex approach to water quality indices. It presupposes a comprehensive review of the water body, taking into account both anthropogenic and natural effects, including the ability to self-purge the water object.

The proposed integrated approach, according to WFD approaches, identifies 5 ecological status for natural water bodies [10, 37]:

1. natural ecological status when natural and anthropogenic impacts on the river are insignificant and the river is in a natural state. 
2. unstable status when there are natural and anthropogenic effects on the aquatic ecosystem, but they are variable and weak. In the event of anthropogenic changes, the ecological status of the river water can easily be changed, returning to the natural state, or, to the contrary, to the 3rd, most stable, polluted state.

3. buffer status, when the "conservative functions" of the river water ecosystem are substantially resistant to anthropogenic influences. River self-cleaning processes reduce human impact on water quality and prevent pollution as much as possible. In this case, long-term anthropogenic impact can eliminate the ability of the river's water ecosystem to self-purify and lead to severe river pollution, the 4 th status.

4. very polluted, transition state, transition from 3rd to buffer status, 5th, eutrophic, status. The 4th transition status between 3rd and 5th degrees is very dangerous for the river water ecosystem and can lead to the river's irreversible pollution and destruction of water bodies. This transitional status of river water quality is seen in the case of long-term high levels of anthrax, in which case the buffer stability of the river water ecosystem is gradually violated. Consequently, in case of taking appropriate environmental measures, the reestablishment of status 4 through 3 also requires a long time and cost. Destruction of buffer waters of the river ecosystems, as well as its rehabilitation can take years and require long-term rehabilitation measures. In the 
case of the 4th status, the evolutionary processes are significantly activated in the river water.

5. eutrophic status, when the eutrophic processes are evident in the river. They bring significant damage to the water ecosystem of the river, break down the natural water-chemical regime and reduce or eliminate biodiversity.

Ecological status of natural waters can be described as the water quality of the water body (G) and the degree of anthropogenic effect $(\mathrm{P})$. This dependence is expressed in the following mathematical equation [91]:

$$
E S=\frac{-10 G \cdot(1+P-G)}{P},
$$

where, ES is the ecological status of a water object, $\mathrm{P}$ is an anthropogenic impact on the water body, $\mathrm{G}$ is the actual water quality of the water object.

The ecological value of a natural water body is determined by the value of the ES.

1st, natural ecological status $(\mathrm{ES}=0-5)$,

2nd, unstable status ( $\mathrm{ES}=6-20)$,

3rd, buffer status $(E S=21-35)$,

4th, extremely polluted, transitional status ( $\mathrm{ES}=36-55)$;

5th, eutrophic status $(E S=56-100)$.

Anthropogenic impact on the quality of natural water is variable and depends on a number of factors.

Therefore, the level of anthropogenic impact of the water quality integrated assessment, $\mathrm{P}$, is regarded as a variable value and determined as a combination of the self-purification ability of a water object, natural factors and the actual water quality. 


$$
[\mathrm{P}]=[\mathrm{G}]+[\mathrm{S}] \cdot \mathrm{a}-[\mathrm{N}],
$$

where, $[\mathrm{P}]$ is an anthropogenic impact on a water object in the form of a variable value, [G] - the actual water quality of a water body as a variable value, [S] is the ability to self-purification capacity of water object; $\alpha$, water buffer activity, $[\mathrm{N}]$ is the ratio of natural factors to the water object.

Numerical methods, biological indicators, maximum permissible concentrations, water quality indicators of different significance are used to determine the actual water quality of the water object. The determination of the actual water quality in the proposed water quality integrated assessment method is based on the water quality indices, in particular the Canadian Water Quality Index. According to the selected hydrochemical indices, CWQI provides a comprehensive description of the degree of pollution of the water object by turning the output indices into relative values and comparing them with the relevant norms or background values.

Each water object is characterized by the ability of selfpurification (self-renewal, ecological ability, buffering, buffer stability). Due to the chemical, physical and biological processes occurring in the water of the natural water body, water ecosystems are capable of neutralizing or substantially minimizing the negative natural and man-made effects.

The ability to self-cleaning during the integrated water quality assessment of the water jet has been considered as a radical self-cleaning ability, which, unlike other types of selfcleaning, is measurable and has a significant contribution to the cost of self-cleaning. It is unstable and depends on the ecological state of the water object as well as the continuity and 
size of anthropogenic effect. Variable values of $[\mathrm{P}]$ and $[\mathrm{S}]$ are opposite, and an elevated anthropogenic pressure leads to a decrease in the river's self-cleaning capacity.

The ability to self-purge in equation (3.4), [S], is determined by the following formula:

$$
S=\frac{\log \sum k_{i}\left[S_{i}\right]}{10 \cdot\left(\log \sum k_{i}\left[S_{i}\right]-\log \sum k_{p}\left[S_{p}\right]\right)},
$$

where $\Sigma \mathrm{k}_{\mathrm{i}}\left[\mathrm{S}_{\mathrm{i}}\right]$ is the inhibitory coefficient measured in that part of the water object, and $\Sigma \mathrm{k}_{\mathrm{mW}}\left[\mathrm{S}_{\mathrm{m}}\right]$, the value of an inhibitory coefficient determined in the pure state of the same water object.

The ability of a water object to self-purge has some limit (threshold level), where structural and functional deviations occur in the high water ecosystem resulting in degradation and destruction. The degree of self-cleaning capacity of water objects is expressed in the equation (3.4) in the form of $\alpha$ coefficients. It is determined as follows:

$$
\alpha=1-\left(\log \sum k_{i}\left[S_{i}\right]-\log \sum k_{p}\left[S_{p}\right]\right),
$$

$\alpha$ conditionally accepts values from 0 to 1 . In the case of natural processes in the aquatic ecosystems, $\alpha$ accepts value 1 . Otherwise, when anthrax is significantly higher, $\alpha$ coefficient tends to 0 . Absolute 0 value of $\alpha$ coefficient means irreducible degradation of aquatic ecosystem, high degree of eutrophication and loss of natural water body (migration).

In addition to the quality of natural water, natural factors also have an impact on anthropogenic impacts that are characterized as changes in the hydro-meteorological and geochemical conditions of the site. The latter predetermine the formation of the rivers' hydrochemical regime, and their modification leads to the change in the chemical composition 
and quality of water. Thus, the coefficient of natural factors in the integrated water quality assessment of the water object is also unstable, depending on the change in climate conditions (observing the geochemical conditions as unchanged) and determined by the following formula:

$$
N=\frac{\sum_{i=1}^{n}\left(C_{i} / c_{\mathrm{p}}\right) \cdot 100}{n},
$$

where $\mathrm{C}_{\mathrm{i}}$ is the concentration of the i-hydrogen-index, $\mathrm{Cm}$, the pure state (background) of the i-hydroeconomic indicator, $\mathrm{n}$ is the number of observed hydrochemical indicators. Here, the concentration of a pure state is taken from the baseline concentration of the given hydrochemical index of 1961-1990.

In the case of high anthropogenic impact on the natural water body, $\alpha \rightarrow 0,[\mathrm{P}]>[\mathrm{N}],[\mathrm{N}]<1$ and $[\mathrm{G}] \cong[\mathrm{P}]$, and in nonsignificant effects, $[P] \rightarrow 0, \alpha=1$ l $[G]=\frac{N^{2}-1}{N}$. In the latter, the actual quality of water is conditioned only by natural factors.

Thus, the integrated determination of the ecological status of natural water quality is widely used and may be used as a practical method for the study and evaluation of natural water quality during the basin management.

The proposed method for integrating the quality of natural water has been used for the Hrazdan River. According to this, the ecological status of the Hrazdan River water was determined and estimated at the upper, middle and lower streams of the river. Monitoring data for following six monitoring observation points were used for assessment:

№52- downstream Argel village, as a background site, №54- downstream Arzni HPP, 
№55- 8km downstream the City of Yerevan, near Darbnik village, after "Aeratsa" wastewater treatment plant,

№56-near river mouth.

From each of the selected points, each sample of water was taken in each month in 2010, which included an inhibitory coefficient, soluble oxygen, hydrogen oxide, $\mathrm{BOD}_{5}$, nitrite, nitrate, ammonium, sulphate, chloride, hydrochloric ions, potassium, magnesium, calcium and sodium concentrations, mining and rigidity.

Determination of an Inhibitory Coefficient. The inhibitory coefficient of the river water was determined by the method of titration with parandrotodimethylalanine (PNDMA). According to this, it was determined during the titration of the PNDMA degradation rate in the distilled water and the tested sample, through which the rate of initiation of each of the $\cdot \mathrm{OH}$ radicals was calculated, followed by the inhibitory coefficient $\left(\sum k_{i}\left[S_{i}\right]\right)$.

$$
\sum k_{i}\left[S_{i}\right]=\frac{V_{\text {total }}}{V_{n w}} k_{a}[\text { PNDMA }]\left(\frac{W_{d w}}{W_{n w}}-1\right),
$$

where $\mathrm{W}_{\mathrm{d} w} / \mathrm{W}_{\mathrm{n}} \mathrm{w}$ is the PNDMA color degradation rates are, respectively, distilled and natural,, $\mathrm{V}_{\text {tot }}$ is total volume of water, $\mathrm{V}_{\mathrm{n} w}$ is volume of taken water, $\mathrm{k}_{\mathrm{a}}$ is the rate of interaction ${ }^{\circ} \mathrm{OH}$ radicals with PNDMA and equals to $1.2510^{10} \mathrm{~mol}^{-1} \mathrm{sec}^{-1}$.

PNDMA titration method is assessed by the intensity of self-cleaning processes involving $\cdot \mathrm{OH}$ radicals in natural waters (radical self-cleaning ability of a natural water body), in particular, the destruction of organic pollutants. For the relatively pure natural water, the inhibitory coefficient accepts 
values less than $10^{4} \mathrm{sec}^{-1}$, and for polluted waters greater than $10^{6} \mathrm{sec}^{-1}$.

Determination of hydrochemical parameters. Water samples taken from the Hrazdan River were determined at the sampling site through the field WTW Multi-340i. $\mathrm{BOD}_{5}$, nitrite, nitrate, ammonium, sulphate, chloride, hydrocarbon ions, potassium, magnesium, calcium and sodium concentrations, mineralization and rigidity values were determined in laboratory conditions using analytical methods corresponding to ISO international standards.

According to the results of the hydrochemical monitoring, based on the Canadian Water Quality Index, the quality of water in the four Hrazdan River points (Table 15) was determined. Then, the values of self-cleaning, buffering, actual water quality and natural factors have been calculated based on the degree of anthropogenic impact and the ecological status of the river (Table 3.31).

Table 3.31

The values for determining the ecological status of

Hrazdan River in 2010.

\begin{tabular}{|c|c|c|c|c|}
\hline $\begin{array}{c}\text { Sampling } \\
\text { point № }\end{array}$ & $\begin{array}{c}\text { \% of } \\
\text { parameters } \\
\text { which exceeded } \\
\text { the norms* } \mathbf{F}_{\mathbf{1}}\end{array}$ & $\begin{array}{c}\text { \% of } \\
\text { analyzes } \\
\text { exceeding } \\
\text { norms, } \mathbf{F}_{\mathbf{2}}\end{array}$ & $\begin{array}{c}\text { The total } \\
\text { number of } \\
\text { results of the } \\
\text { analysis, } \mathbf{n}\end{array}$ & $\begin{array}{c}\text { Excessive } \\
\text { Excellence, } \\
\mathbf{F}_{\mathbf{3}}\end{array}$ \\
\hline 52 & 16.67 & 9.38 & 128 & 3.73 \\
\hline 54 & 33.33 & 16.13 & 124 & 13.24 \\
\hline 55 & 25.0 & 25.37 & 134 & 78.35 \\
\hline 56 & 41.67 & 26.32 & 133 & 55.06 \\
\hline
\end{tabular}

* Water quality standards used for water-chemical indicators have been used. 
According to the Ecological Status (ES) values, the ecological status of the Hrazdan River has been assessed: №52$2^{\text {nd }}$, unstable status, №54- $3^{\text {rd }}$, buffer status, №55-4 ${ }^{\text {th }}$ and $5^{\text {th }}$, eutrophic boundary line, №56-4 ${ }^{\text {th }}$, extremely polluted, transitional status.

Table 3.32

Parameters determining the ecological status of Hrazdan River

in 2010.

\begin{tabular}{|c|c|c|c|c|c|c|}
\hline $\begin{array}{c}\text { Sampling } \\
\text { point № }\end{array}$ & $\begin{array}{c}\text { Actual } \\
\text { water } \\
\text { quality } \\
\text { index G }\end{array}$ & $\begin{array}{c}\text { Natural } \\
\text { factors, } \\
\mathbf{N}\end{array}$ & $\begin{array}{c}\text { Self- } \\
\text { purification } \\
\text { capacity, S }\end{array}$ & $\begin{array}{c}\text { Buffer } \\
\text { capacity, } \\
\propto\end{array}$ & $\begin{array}{c}\text { Anthropo- } \\
\text { genic } \\
\text { impact, P }\end{array}$ & ES \\
\hline 52 & 11.25 & 4.5 & 3.48 & 0.846 & 9.69 & 6.5 \\
\hline 54 & 22.71 & 6.6 & 3.22 & 0.833 & 18.79 & 35.3 \\
\hline 55 & 49.69 & 7.5 & 2.00 & 0.726 & 43.64 & 57.5 \\
\hline 56 & 42.66 & 7.35 & 2.34 & 0.768 & 37.11 & 52.3 \\
\hline
\end{tabular}

The highest degree of anemia was observed in the midstream of Hrazdan River, downstream from Yerevan, where the ecological status of the river corresponded to the 4th and 5th eutrophic limits. The ecological status of the river valley has been restored to a 4th, heavily polluted, transitional state, with a reduction in self-cleaning processes and anthropogenic impact. The impact of natural factors on the quality of water at the entire stream of the Hrazdan River has been relatively constant and not significant.

Thus, the Hrazdan River Water Quality Assessment, in the nominal integrated way, shows that natural effects are essential only on the rocks of the river, and along the river, downstream, with anthropogenic impact, they do not play a role in changing water quality. Due to the high degree of anthropogenic effect, 
the water downstream also reduces the self-cleaning ability. Although, according to the $\alpha$ values, the river water has a large buffer, it decreases in the lower streams of the river due to its high anthropogenic impact. Low self-cleaning and buffering values as well as the worst ecological status have been observed in the Hrazdan River, downstream from the city of Yerevan, from $13 \mathrm{~km}$ to the estuary to a considerable degree of selfcleaning due to anthropogenic effect [17].

\subsection{New method for natural Water Quality Prediction based on climate change scenarios}

One of the serious contemporary challenges in the World is the global climate change, impact which has already felt across the globe. Changes in water resources availability, stream flow and in river ecosystems are the major expected impacts of climate changes in watersheds. Due to increase in air temperature and reduce of precipitation, the shortage of water supply and an increase in water demand are enhanced. According to the World Bank assessment, Armenia is among the most sensitive countries in the Europe and Central Asia region in regard to climate change, the impact of which has been already revealed on freshwater resources of the country. Based on long-term meteorological studies, there is a decrease in the maximum and minimum river flow by $3-5 \%$ for the most of the rivers in the country. The climate change is expected to influence the quantity as well as the quality of freshwater resources by, for instance, increasing "natural" pollution. Consequently, it may lead to deterioration of water resources 
and destruction of ecosystems, along with extinction of endemic species of flora and fauna [24].

In order to investigate the impact of climate change on the natural water quality, in particular, a hydrochemical content of natural water body, the appropriate water quality assessment and prediction methods should be applied. There are several hydrological studies related to quantitative assessment of river flow conditions due to changes on climate indicators that are listed in the USAID (2012) research report [69]. Most of these studies used often, hypothetical scenarios of possible changes of air temperature and deposits, as a rule, due to climate change. However, there are seldom studies on the water resources quality changes caused by climate change.

Currently, the several water quality prediction methods are known, such WEAP, BASINS 4.0 Climate Assessment Tool (CAT), SWAT, NEVA, CHyM and DSS. The existing methods are based on several mathematical models, which are difficult to apply and need long-term data series [125].

For this purpose, we offer a new method for natural water quality assessment and prediction based on IPCC climate change scenarios. The present study investigates the impact of the climate change on water resources and prediction of the hydro- parameters change, namely, the river runoff and concentration of the main hydrochemical parameters (major ions, ammonium and nitrate nitrogen, phosphorus, etc), applying new and easy assessment approach method, which combines the water quantity and quality.

Water Quality Prediction Method Development. The method based on the combination of the hydrochemical and 
hydrological parameters together and their possible variations by 2 main climate change scenarios: A2 scenario= business-asusual and B1 scenario=with mitigation measures. In order to combine the hydrological and hydrochemical parameters for integrated assessment and prediction of natural water quality changes as a result of climatic changes of the region, it was suggested new method - The Predicted Concentration of Hydrochemical Parameter (PCHP) based on the River Flow Substance Quantity Transfer Index (RFSQTI). Through RFSQTI it is possible to calculate annual or monthly quantity of transferring substance by river flow. Also, it is allowed for longterm calculation dynamics, usually per five years. Combination of the RFSQTI with calculation methods of the water balance and the natural flow changes through climate change scenarios for a water body makes it possible to predict the concentration changes of each hydrochemical parameters. The PCHP method has a wide spectrum of hydrochemical parameters' prediction possibility, such as mineralization, heavy metals, hardness, total nitrogen, phosphorus and etc.

At first, the annual flux of subject substance, then the anthropogenic impacts and correction factor for the difference of water flow during the study and background periods are calculated. So, the total amount of flux amount of the substance (RFSQTI) for relevant period is calculated as:

$$
G_{p}=G_{a}+\frac{W_{a}}{W_{B P}} \cdot G_{f} .
$$

The water balance for rivers mathematically expressed as follow: 


$$
W_{n}=W_{a}+U_{I}+U_{\text {other }} \pm T,
$$

where $W_{n}$ is natural flow; $W_{a}$ - actual flow; $U_{I}$ - water flow that uses for irrigation proposes; $U_{\text {other }}=$ water flow that uses for other proposes (drinking, industrial, etc.); $\mathrm{T}$-transfer flow.

Natural flow $\left(W_{n}\right)$ predictions should be calculated according to climate change scenarios. Projections of future climate change in a watershed can be performed with PRECIS regional climate modeling system, which is based on the third generation regional climate model (HadRM3), developed by the UK Met Office Hedley Center. HadRM3 uses the output data of global climate models (GCMs) and performs a dynamic downscaling, in order to acquire regional-scale climate projections with the resolution of $0.22^{0} \times 0.22^{0}(25 \times 25 \mathrm{~km})$. Temperature and precipitation are first simulated in PRECIS for the base period of 1961-1990 and the periods of 2011-2040, 2041-2070, and 2071-2100, under A2 and B1 emission scenarios, developed by Intergovernmental Panel on Climate Change (IPCC). For water quality prediction it is not recommended to go so far, and it will be better to use short time predictions, such as 6,12 and 18 years. After the temperature and precipitation simulations, the assessment of the vulnerability of the water resources (a water flow change) in watershed should be conducted by applying a physical-statistical regression modeling method. For simulation of the natural flow under climate change scenarios, the annual average natural river flow and the multi-annual observation data on precipitation and air temperature, collected by PRECIS regional climate modeling 
system are used by establishing a correlation between the mentioned parameters through regression.

After calculating the predicted natural flow by appropriate climate change scenario, the actual flow of river should be determined for the same predicted year, according to eq. (3.10).

$$
W_{\text {al pred }}=W_{n / \text { pred }}-U_{I / \text { pred }}-U_{\text {other/ pred }} \pm T_{\text {pred }} \text {. }
$$

Based on the eq. (3.9) and (3.11), the predicted amount of flux amount of the substance (Gp/pred) (the prediction should be given for 2020, 2025, etc.) can be calculated as:

$$
G_{p / \text { pred }}=G_{a / \text { pred }}+\frac{W_{a / \text { pred }}}{W_{B P}} \cdot G_{f} .
$$

The values of the anthropogenic component of flux amount of subject substance $\left(\mathrm{G}_{\mathrm{a}}\right)$ directly depend on the emission scenarios type. In the case of A2 (business-as-usual) scenario, when the continuous emission of pollutants without their amount's reduction is stimulated, as the amount of $G_{a}$ in shortterm forecasting is offered to take the arithmetic mean or progressive growth of the $\mathrm{G}_{\mathrm{a}}$ for last 3 years (eq. (3.13)).

$$
G_{a / A_{2} \text { pred }}=\sum_{i=1}^{3} \overline{G_{a}} \text {. }
$$

Based on eq. (3.12), the Predicted Concentration of Hydrochemical Parameter (PCHP) for A2 emission scenario will be calculated as:

$$
C_{p / \text { A2pred }}=\frac{\sum_{i=1}^{3} \bar{G}_{a}+\frac{W_{a / A_{2} p r e d}}{W_{B P}} \cdot G_{f}}{31.536 \cdot W_{a / A_{2} p r e d}} .
$$


In the case of B1 (with mitigation measures) scenario, when the reduction of emission of pollutants and environmental measures implementation are simulated, the environmental investment coefficient $(\beta)$ for calculation of $\mathrm{Ga}$ in short-term forecasting is introduced.

$$
G_{a / B 1 \text { pred }}=\beta \cdot G_{a} .
$$

The value of $\beta$ depends on type and amount of upcoming environmental measures to improve water quality of a subject water body. The environmental measures to improve the water quality may be technical, institutional or legislative (totally five main environmental measures). Building of wastewater treatment plant, establishing sustainable agriculture, reduction of solid waste pollution are the examples of technical environmental measures. $\beta$ values rages from 0 to 1 . $\beta$ equal to 0 , when all kinds of environmental measures would be conducted in the predicted period, and $\beta=1$, if no any environmental measures would be taken. For A2 scenario the $\beta=1$, and for B1 scenario $\beta$ should be calculates as follow: for each environmental measure $\left(\beta_{\mathrm{i}}\right)$ it is equal $0.2-\beta=1-\beta_{\mathrm{i}}$ :

Thus, the Predicted Concentration of Hydrochemical Parameter (PCHP) for B1 emission scenario will be calculated as:

$$
C_{p / B 1 \text { pred }}=\frac{\beta \cdot G_{a}+\frac{W_{a / B_{1} \text { pred }} \cdot G_{f}}{W_{B P}}}{31.536 \cdot W_{a / B_{1} \text { pred }}}
$$

Eq. (3.14) and eq. (3.16) help to predict the changes in concentrations of each hydrochemical parameters in the water body during short term period (5-12 years), based on A2 and B1 climate scenarios. 
The suggested method of emission scenarios based water quality prediction involves minor uncertainty. No one can predict what pollutant loadings will occur in the future, especially from area-wide non-point sources. However, the method available to help scientists and water managers predict water quality impacts that are relatively simple compared to the complexities of the actual water ecosystem.

\subsubsection{Prediction of the quality of natural water according to the concentration of the hydrochloric acid}

An example of the proposed method of predicting natural water quality is the study and forecast of the Voghji River water quality based on the long-term water monitoring results from 2020-2025. Water quality predictions have been implemented at the monitoring station downstream of the Kapan town (No. 94) [17], where the water is polluted with mining wastewater, city municipal waste water, and back flow from agriculture. In this part of the Voghji River, water is intensively polluted with nitrate, ammonium, phosphate ions, and heavy metals (copper, zinc, molybdenum). Located under constant elevated anthrax, the river's water is in the category of poor $(\mathrm{V})$ quality of water.

For this purpose, possible changes in nitrate, ammonium ions, copper and zinc concentrations in the river water (A2 screenplay) in the case of irreversible anthropogenic impacts have been studied and predicted in the coming years, 20202025.

For forecasting purposes, the hydrochemical and hydrological data for 2008-2015 of the Voghji River at №94 sampling point were used. 
Table 3.33.

The average annual values of hydrochemical indicators in the sampling point downstream of the Kapan town of Voghji River.

\begin{tabular}{|c|c|c|c|c|}
\hline \multirow{2}{*}{ Years } & \multicolumn{4}{|c|}{ Concentrations of parameters (C), mg/dm } \\
\cline { 2 - 5 } & Nitrate nitrogen & $\begin{array}{c}\text { Ammonium } \\
\text { nitrogen }\end{array}$ & Copper & Zinc \\
\hline 1980 & 0.890 & 0.000 & 0.008 & 0.001 \\
\hline 2008 & 0.778 & 0.763 & 0.112 & 0.079 \\
\hline 2009 & 0.652 & 0.453 & 0.094 & 0.096 \\
\hline 2010 & 0.915 & 0.470 & 0.093 & 0.074 \\
\hline 2011 & 0.979 & 0.417 & 0.128 & 0.109 \\
\hline 2012 & 1.088 & 0.894 & 0.120 & 0.108 \\
\hline 2013 & 0.806 & 0.636 & 0.110 & 0.114 \\
\hline 2014 & 0.931 & 1.190 & 0.120 & 0.139 \\
\hline 2015 & 0.952 & 0.670 & 0.122 & 0.137 \\
\hline
\end{tabular}

First of all, according to the average annual data, the amount of nitrous nitrogen, ammonium nitrogen, copper and zinc (G) transported by river flow was determined and then the cost of an NHS antibacterial value was calculated for each year.

The background period was taken in 1980 when mining in the region was still developing and the environmental damage was minimal. ITQSRF and ITQSRF $F_{\text {ant }}$ values indicate that most of the ammonium ion, copper, and zinc quantities in the river water are caused by anthropogenic influences that have continued to grow over the years.

In order to predict the possible changes in the hydrogenbased concentrations of the Voghji River water, it is necessary to forecast the natural flow rate (natural water flow of the river, $\mathrm{m}^{3} / \mathrm{sec}$ ) in 2020-2025 at A2 scenario. Regression physics- 
statistical analytical method was used to predict the river's natural flow. For this reason, the actual water outlet data from the river has been transposed into water. The natural flow of river water was determined by a water economy balance (3.19) for which the abstraction rates granted to all water users in the downstream part of the Voghji River Kapan were examined, as well as the amount of waste water discharges (Table 3.34).

Table 3.34.

The values of the ITQSRF and ITQSRF ant $_{\text {at }}$ the sampling point downstream the Kapan town of the Voghji River, according to various hydrochemical indicators.

\begin{tabular}{|c|c|c|c|c|}
\hline \multirow{2}{*}{ Years } & \multicolumn{4}{|c|}{ ITQSRF, G tons/year } \\
\cline { 2 - 5 } & Nitrate nitrogen & $\begin{array}{c}\text { Ammonium } \\
\text { nitrogen }\end{array}$ & Copper & Zinc \\
\hline 1980 & 417.10 & 0.00 & 3.95 & 0.29 \\
\hline 2008 & 95.19 & 93.39 & 13.71 & 9.69 \\
\hline 2009 & 164.83 & 114.51 & 23.78 & 24.26 \\
\hline 2010 & 245.27 & 126.09 & 24.89 & 19.93 \\
\hline 2011 & 144.90 & 61.65 & 18.95 & 16.08 \\
\hline 2012 & 180.38 & 148.18 & 19.83 & 17.96 \\
\hline 2013 & 132.17 & 104.30 & 18.04 & 18.69 \\
\hline 2014 & 131.24 & 167.75 & 16.92 & 19.59 \\
\hline 2015 & 127.29 & 89.59 & 16.31 & 18.32 \\
\hline 2008 & -13.76 & 93.39 & 12.67 & 9.61 \\
\hline 2009 & -60.11 & 114.51 & 18.25 & 24.10 \\
\hline 2010 & 6.72 & 126.09 & 22.63 & 19.77 \\
\hline 2011 & 13.17 & 61.65 & 17.70 & 15.99 \\
\hline 2012 & 32.79 & 148.18 & 18.44 & 17.86 \\
\hline 2013 & -13.77 & 104.30 & 16.66 & 18.59 \\
\hline 2014 & 5.78 & 167.75 & 15.73 & 19.51 \\
\hline 2015 & 8.29 & 89.59 & 15.19 & 18.24 \\
\hline
\end{tabular}


Using data from the annual and monthly average natural flow and meteorological stations precipitation and air temperature monitoring data for the Voghji-Kapan observation station on the Voghji River, a correlation was established between the above mentioned elements in regression, change of A2 scenario (Table 3.34).

Taking into consideration the fact that the water use permits (WUPs) are issued for a period of 5-8 years, their quantities will not change until 2025. Consequently, the natural flow of the predicted river can easily be overcome with the predicted actual flow. Having the predicted actual flow values of the Voghji River, the A2 scenario (26) proposed by the proposed water quality prediction method can calculate the concentrations of hydrochemicals studied in 2016-2020.

Table 3.35.

Annual average actual, Natural flows, Total Water Abstraction and Wastewater discharge at Voghji-Kapan sampling point (based on

\begin{tabular}{|c|c|c|c|}
\hline Years & $\begin{array}{c}\text { The average } \\
\text { annual actual } \\
\text { flow of the } \\
\text { river, } \mathbf{~ m}^{\mathbf{3}} / \mathbf{s e c}\end{array}$ & $\begin{array}{c}\text { The average } \\
\text { annual natural } \\
\text { flow of river } \\
\text { water, } \mathbf{~ m}^{\mathbf{3}} / \mathbf{s e c}\end{array}$ & $\begin{array}{c}\text { Amount of water } \\
\text { and water volume } \\
\text { determined by WUP, } \\
\mathbf{~ m}^{\mathbf{3}} / \mathbf{s e c}\end{array}$ \\
\hline 1980 & 14.86 & 15.47 & 0.61 \\
\hline 2008 & 3.88 & 4.60 & 0.72 \\
\hline 2009 & 8.01 & 8.74 & 0.73 \\
\hline 2010 & 8.50 & 9.24 & 0.74 \\
\hline 2011 & 4.69 & 5.44 & 0.74 \\
\hline 2012 & 5.26 & 6.00 & 0.74 \\
\hline 2013 & 5.55 & 6.29 & 0.74 \\
\hline 2014 & 4.60 & 5.34 & 0.74 \\
\hline 2015 & 5.17 & 5.91 & 0.74 \\
\hline
\end{tabular}


In the formula instead of the three-year average value of the ITQSRF $_{\text {ant }}$ of the hydrochemical parameters, it can also be taken as the value of its progressive growth as the incremental increase is observed for the values of the 2008-2015 values for the ITQSRF $_{\text {ant }}$.

Table 3.36.

Modeled annual values of river water outlet at Voghji-Kapan observation point, according to the IPCC A2 scenario.

\begin{tabular}{|c|c|c|}
\hline Years & $\begin{array}{c}\text { The average annual } \\
\text { natural flow of the river, } \\
\mathbf{m}^{\mathbf{3}} \mathbf{\text { sec }}\end{array}$ & $\begin{array}{c}\text { The average annual } \\
\text { expected actual flow } \\
\text { of the river, } \mathbf{~ m}^{\mathbf{3}} / \mathbf{s e c}\end{array}$ \\
\hline $\begin{array}{c}\text { Basis period: } \\
1961-1990\end{array}$ & 12.28 & - \\
\hline 2018 & 5.48 & 4.74 \\
\hline 2019 & 5.47 & 4.73 \\
\hline 2020 & 5.45 & 4.71 \\
\hline 2025 & 5.43 & 4.69 \\
\hline
\end{tabular}

Accordingly, a graph of the annual change in the ITQSRF $F_{\text {ant }}$ values of each hydrochemical indicator was constructed, from which the straight-line dependency formula was determined. In this way, the predicted values of the ITQSRF $\mathrm{ant}_{\mathrm{an}}$ are shown in Table 3.36. To evaluate the most stringent scenario, it is recommended to take the progressive growth values to predict the ITQSRF ${ }_{\text {ant }}$, otherwise, the average value of the last three years.

The anticipated concentrations of nitrate nitrogen, ammonium nitrogen, copper and zinc determined base on the predicted actual flow and ITQSRF $F_{\text {ant }}$ values are estimated at 2020-2025 for A2 scenario are shown in Tables 3.37 and 3.38. 
Table 3.37.

The ITQSRF $_{\text {ant }}$ (Gant tons/year) projected values for the given hydrochemical parameter at Voghji river, according to the IPCC A2

scenario.

\begin{tabular}{|c|c|c|c|c|}
\hline Years & $\begin{array}{c}\text { Nitrate } \\
\text { nitrogen }\end{array}$ & $\begin{array}{c}\text { Ammonium } \\
\text { nitrogen }\end{array}$ & Copper & Zinc \\
\hline $\begin{array}{c}\text { Three-year } \\
\text { average }\end{array}$ & 15.62 & 120.54 & 15.86 & 18.78 \\
\hline 2018 & 15.80 & 124.05 & 16.65 & 19.45 \\
\hline 2019 & 21.06 & 127.15 & 16.50 & 19.87 \\
\hline 2020 & 26.32 & 130.25 & 16.36 & 20.30 \\
\hline 2025 & 52.63 & 145.78 & 15.63 & 22.43 \\
\hline
\end{tabular}

The obtained forecast data show that for the prediction of water quality in the downstream part of the Voghji River, it is more expedient to use the progressive ITQSRF $_{\text {ant }}$ progressive values.

Table 3.38.

The concentrations of hydrochemical parameters in the Voghji-Kapan observation point based onITQSRFant values for predictive three-year average estimates in the case of the IPCC A2 scenario.

\begin{tabular}{|c|c|c|c|c|}
\hline \multirow{2}{*}{ Years } & \multicolumn{4}{|c|}{ Concentrations of Parameters, $\mathbf{m g} / \mathbf{d m}^{\mathbf{3}}$} \\
\cline { 2 - 5 } & $\begin{array}{c}\text { Nitrate } \\
\text { nitrogen }\end{array}$ & $\begin{array}{c}\text { Ammonium } \\
\text { nitrogen }\end{array}$ & Copper & Zinc \\
\hline 2015 & 0.952 & 0.670 & 0.122 & 0.137 \\
\hline 2018 & 0.994 & 0.806 & 0.114 & 0.1262 \\
\hline 2019 & 0.995 & 0.809 & 0.115 & 0.1266 \\
\hline 2020 & 0.995 & 0.812 & 0.115 & 0.1271 \\
\hline 2025 & 1.424 & 0.832 & 0.129 & 0.1698 \\
\hline
\end{tabular}

Thus, the results of the water quality prediction method indicate that the nitrous, ammonium nitrogen and zinc 
concentrations will increase up to 1.2-1.5 times in the Voghji River up to 2025 by 2015 , and the copper will change slightly, 1.1 times. The assessment is a signal that the Voghji River water quality improvement measures will be taken to reduce the concentration of nitrates and nitrates in the water.

River water in the Voghji river basin is constantly polluted with heavy metals that gradually eliminate water biodiversity. Although the high concentrations of copper and zinc in water are not yet discovered for human health, they are toxic and cause serious damage to water ecosystems.

Table 3.39.

The concentrations of hydrochemical parameters in the Voghji-Kapan sampling point according to the ITQSRF ${ }_{\text {ant }}$ prediction of progressive growth, in the case of the IPCC A2 scenario.

\begin{tabular}{|c|c|c|c|c|}
\hline \multirow{2}{*}{ Year } & \multicolumn{4}{|c|}{ Concentrations of parameters, $\mathbf{~ m g / \mathbf { d m } ^ { \mathbf { 3 } }}$} \\
\cline { 2 - 5 } & $\begin{array}{c}\text { Nitrate } \\
\text { nitrogen }\end{array}$ & $\begin{array}{c}\text { Ammonium } \\
\text { nitrogen }\end{array}$ & Copper & Zinc \\
\hline 2015 & 0.952 & 0.670 & 0.122 & 0.137 \\
\hline 2018 & 0.996 & 0.829 & 0.120 & 0.131 \\
\hline 2019 & 1.031 & 0.853 & 0.119 & 0.134 \\
\hline 2020 & 1.067 & 0.877 & 0.119 & 0.137 \\
\hline 2025 & 1.246 & 0.986 & 0.114 & 0.152 \\
\hline
\end{tabular}

For the purpose of researching the effectiveness of water quality improvement measures and the reduction of the concentrations of hydrogen-based indicators in the Voghji River, a B1 (mild) scenario has been developed in this work. For this reason, the PRECIS regional climatic model was determined at the Voghji-Kapan point of view for the natural and actual flow of the river 2020-2025, according to the scenario B1 (Table 3.39). 
According to the B1 scenario, the B1 scenario proposed the proposed water quality prediction method has determined the concentrations of hydrochloric acid in the river water (Table 3.40). The 0.5 value for the $\beta$ coefficient describing water quality improvement measures has been taken, assuming that in the upcoming years half of the necessary environmental measures will be undertaken in Voghji River Basin.

Table 3.40.

The model annualized values of the river water outlet at Voghji-Kapan sampling point, according to the IPCC B1 scenario.

\begin{tabular}{|c|c|c|}
\hline Year & $\begin{array}{c}\text { The average annual } \\
\text { natural flow of the } \\
\text { river, } \mathbf{~ m}^{\mathbf{3}} / \mathbf{s e c}\end{array}$ & $\begin{array}{c}\text { The average annual } \\
\text { expected actual flow of the } \\
\text { river, } \mathbf{~}^{\mathbf{3}} \mathbf{s e c}\end{array}$ \\
\hline $\begin{array}{c}\text { Basis period: } \\
1961-1990\end{array}$ & 12.28 & - \\
\hline 2018 & 5.64 & 4.90 \\
\hline 2019 & 5.63 & 4.89 \\
\hline 2020 & 5.62 & 4.88 \\
\hline 2025 & 5.62 & 4.89 \\
\hline
\end{tabular}

Table 3.41.

The results of forecasting hydrochemical values in the Voghji-Kapan sampling point according to the $B 1$ scenario.

\begin{tabular}{|c|c|c|c|c|}
\hline \multirow[b]{2}{*}{ Year } & \multicolumn{4}{|c|}{ Concentrations of parameters, $\mathrm{mg} / \mathrm{dm}^{3}$} \\
\hline & $\begin{array}{c}\text { Nitrate } \\
\text { nitrogen }\end{array}$ & $\begin{array}{c}\text { Ammonium } \\
\text { nitrogen }\end{array}$ & Copper & Zinc \\
\hline 1980 & 0.890 & 0.000 & 0.008 & 0.001 \\
\hline 2015 & 0.952 & 0.670 & 0.122 & 0.137 \\
\hline 2018 & 0.904 & 0.090 & 0.024 & 0.015 \\
\hline 2019 & 0.897 & 0.045 & 0.016 & 0.008 \\
\hline 2020 & 0.894 & 0.023 & 0.012 & 0.004 \\
\hline 2025 & 0.891 & 0.019 & 0.011 & 0.003 \\
\hline
\end{tabular}


The water quality B1 scenario forecasting results show that whenever appropriate environmental measures are taken, the water quality will be gradually improved in the downstream part of the Voghji River from Kapan, seeking better grades (III) and good (II) quality classes. Unlike the A2 scenario, in 2025, the concentrations of the hydrochemicals studied will increase by about 1.2-1.5 times as compared to 2015, in the case of the B1 scenario, these concentrations will decrease by about 11.1 times, in copper 45.7 times, in zinc 35.3 times, ammonium nitrogen and 1.1 times in the case of nitrous nitrogen.

Thus, only the urban sewage treatment plant can be reduced up to 35 times by reducing the ammonium ion concentration in the Voghji River and the construction of an industrial wastewater treatment plant for 11 to 45 times the metal concentrations. By estimating the water quality as predicted by this prediction, it becomes clear that in the case of the A2 (severe) scenario of the Voghji River by 2025, the quality of the disturbing water will be affected by damaged aquatic ecosystem, and in the case of B1 (mild) scenario, water quality improvements, Approaching the background ecological state. This method also predicts the extent to which the river will be rebuilt in the case of each type of environmental event as well as select the type of optimum and priority water quality improvement event. For example, the priority for the Voghji River is the introduction of the municipal waste water treatment plant and the mining wastewater treatment system. 


\section{Chapter 4. Natural Water Quality Assessment Methods}

\subsection{New system for surface water quality assessment in Armenia, based on EU WFD}

According to the Water Framework Directive (WUA) (2000/60 / EC) developed by the European Union (EU), all European surface waters should be in good ecological condition after 2015, and water objects with poor quality water should be improved through targeted measures quality to a better status. Each EU Member State has developed classroom schemes for water quality classification according to WFD [10]. For example, in France, the SEQ-system is used for the classification of river water quality, consisting of three sections. To classify water quality, 15 descriptors are separated into 156 indicators, taking into account similar factors and effects. The evaluation is carried out using the boundary value table, which defines the boundaries of classes [40].

Then the index values are calculated based on which the water quality is classified into 5 classes based on the water useability. Germany's chemical quality classification scheme consists of 4 main classes and 3 subclasses, with a similar biological classification. The grades obtained are mapped through color codes.

Water quality assessment in the Danube River Basin according to the EU WFD (2000/60/EC) program is carried out according to separate indicators $[10,40]$. In this classification scheme, indicators are classified into five classes. Class I is 
referred to as "reference" or background concentration; class II is a target value that should be followed; the III-V classes are part of the "non-executable" classification scheme and their values are usually 2-5 times higher than the target value.

According to the EU WFW Rural Water Quality Assessment, due to the lack of biological monitoring, assessment was made only with the use of water quality chemical indicators. Natural background concentrations of hydrochemical indices were taken into account. The determination of background concentrations according to the EU WFD was performed using a statistical method using the probability logarithmic distribution function. The expected background status of the reference state is the absence or insignificance of anthropogenic pressure. It is closely connected with Background concentration (BC). Background concentration is the value of the water quality indicator concentration before exposure to any source of pollution.

The calculations of the $\mathrm{BC}$ took place in the RA rivers in 2005-2010 hydrochemical monitoring.

The Government of the Republic of Armenia ("Decree N75$\mathrm{N}$ of 27 March 2011") establishes the surface water quality assessment system in Armenia for each indicator of the water quality for each watercourse by the decision of the Government of the Republic of Armenia "On Establishment of Water Quality Assurance Standards for each Water Basin Management Area" five class status: "excellent" (1st grade), "good" (2nd grade), "mediocre" (3rd grade), "insufficient" (grade 4) and "bad" (5class). The general assessment of the chemical quality of water is shaped by the class of the lowest quality indicator. 
If the different indicators of the quality of the surface water object fall into different classes of quality, the final classification is considered the worst. The following principle applies: "If someone is in bad shape, then everyone is in a bad condition" or "one is out, everyone is out" principle.

Table 4.1.

Water quality classification by EU WFD.

\begin{tabular}{|c|c|c|}
\hline Water quality class & Assessment & Water quality \\
\hline 1 & & Excellent \\
\hline 2 & & Good \\
\hline 3 & & Moderate \\
\hline 4 & & Unsatisfactory \\
\hline 5 & & Bad \\
\hline
\end{tabular}

The advantages of the new norms of water quality in Armenia are:

- The classification of environmental norms is based on the natural BCs.

- Selection of indicators was made taking into account the pressures on the surface water of the Republic of Armenia (mainly 43 indicators).

- Disclosure of real pressures on water quality.

- Detection of river basin pollutants.

- Established for 14 major river basins in Armenia. 
Table 4.2

Ecological norms of the water quality of the River Basin River basin in the Northern Basin Management Area according to the RA Government Decree N 75-N of January 27, 2011

\begin{tabular}{|l|c|c|c|c|c|c|}
\hline \multirow{2}{*}{ Parameters } & \multicolumn{7}{|c|}{ Water quality class } & \multirow{2}{*}{ Unit } \\
\cline { 2 - 6 } & I & II & III & IV & V & \\
\hline DO & $>7$ & $>6$ & $>5$ & $>4$ & $<4$ & $\mathrm{mgo}_{2} / \mathrm{L}$ \\
\hline BOD $_{5}$ & 3 & 5 & 9 & 18 & $>18$ & $\mathrm{mgo}_{2} / \mathrm{L}$ \\
\hline COD-Cr & 10 & 25 & 40 & 80 & $>80$ & $\mathrm{mgo}_{2} / \mathrm{L}$ \\
\hline SS & 2.84 & 3.41 & 5.68 & 11.36 & $>11.36$ & $\mathrm{mg} / \mathrm{L}$ \\
\hline Mineralization & 142 & 284 & 1000 & 1500 & $>1500$ & $\mathrm{mg} / \mathrm{L}$ \\
\hline Ammonium ion & 0.191 & 0.4 & 1.2 & 2.4 & $>2.4$ & $\mathrm{mgN} / \mathrm{L}$ \\
\hline Nitrate ion & 0.012 & 0.06 & 0.12 & 0.3 & $>0.3$ & $\mathrm{mgN} / \mathrm{L}$ \\
\hline Nitrite ion & 1.62 & 2.5 & 5.6 & 11.3 & $>11.3$ & $\mathrm{mgN} / \mathrm{L}$ \\
\hline Phosphate ion & 0.031 & 0.1 & 0.2 & 0.4 & $>0.4$ & $\mathrm{mg} / \mathrm{L}$ \\
\hline Zinc & 4.3 & 100 & 200 & 500 & $>500$ & $\mathrm{microg} / \mathrm{L}$ \\
\hline Copper & 3.0 & 23.0 & 50 & 100 & $>100$ & $\mathrm{microg} / \mathrm{L}$ \\
\hline Chromium & 1.3 & 11.3 & 100 & 250 & $>250$ & $\mathrm{microg} / \mathrm{L}$ \\
\hline Arsenic & 0.42 & 20 & 50 & 100 & $>100$ & $\mathrm{microg} / \mathrm{L}$ \\
\hline Cadmium & 0.24 & 1.24 & 2.24 & 4.24 & $>4.24$ & $\mathrm{microg} / \mathrm{L}$ \\
\hline Lead & 0.66 & 10.66 & 25 & 50 & $>50$ & $\mathrm{microg} / \mathrm{L}$ \\
\hline Nickel & 1.10 & 11.10 & 50 & 100 & $>100$ & $\mathrm{microg} / \mathrm{L}$ \\
\hline Molybdenium & 0.76 & 1.52 & 3.04 & 6.08 & $>6.08$ & $\mathrm{microg} / \mathrm{L}$ \\
\hline Manganese & 32.0 & 64.0 & 128.0 & 256.0 & $>256.0$ & $\mathrm{microg} / \mathrm{L}$ \\
\hline Vanadium & 2.9 & 5.8 & 11.6 & 23.2 & $>23.2$ & $\mathrm{microg} / \mathrm{L}$ \\
\hline Cobalt & 1.4 & 2.8 & 5.6 & 11.2 & $>11.2$ & $\mathrm{microg} / \mathrm{L}$ \\
\hline Iron & 0.09 & 0.18 & 0.5 & 1 & $>1.00$ & $\mathrm{mg} / \mathrm{L}$ \\
\hline Calcium & 40 & 100 & 200 & 300 & $>300$ & $\mathrm{mg} / \mathrm{L}$ \\
\hline Magnesium & 7.2 & 50 & 100 & 200 & $>200$ & $\mathrm{mg} / \mathrm{L}$ \\
\hline Potassium & 1.4 & 2.8 & 5.6 & 11.2 & $>11.2$ & $\mathrm{mg} / \mathrm{L}$ \\
\hline Sodium & 9.02 & 18.04 & 36.08 & 72.16 & $>72.16$ & $\mathrm{mg} / \mathrm{L}$ \\
\hline Aluminum & 258.6 & 517.2 & 1034.4 & 5000 & $>5000$ & $\mathrm{microg} / \mathrm{L}$ \\
\hline Selen & 1 & 20 & 40 & 80 & $>80$ & $\mathrm{microg} / \mathrm{L}$ \\
\hline Antimony & 0.22 & 0.44 & 0.88 & 1.76 & $>1.76$ & $\mathrm{microg} / \mathrm{L}$ \\
\hline Tin & 0.11 & 0.22 & 0.44 & 0.88 & $>0.88$ & $\mathrm{microg} / \mathrm{L}$ \\
\hline COD-Mn & 2.21 & 10 & 15 & 20 & $>20$ & $\mathrm{mgo} / 2 / \mathrm{L}$ \\
\hline $\begin{array}{l}\text { Total } \\
\text { phosphorus }\end{array}$ & 0.050 & 0.2 & 0.4 & 1 & $>1$ & $\mathrm{mg} / \mathrm{L}$ \\
\hline Chloride ion & 6.3 & 12.6 & 150 & 200 & $>200$ & $\mathrm{mg} / \mathrm{L}$ \\
\hline Sulfates ion & 35.42 & 70.84 & 150 & 250 & $>250$ & $\mathrm{mg} / \mathrm{L}$ \\
\hline
\end{tabular}


Selection of reference points for the basins of the Republic of Armenia based on following criteria:

1. Southern Basin Management Area, Vorotan and Voghji River Basins.

2. Ararat Valley Basin Management Area, Arpa, Vedi and Azat River Basins.

3. River basin of Lake Sevan, Argichi, Karchaghbyur, Masrik, Sotk, Dzknaget and other river basins.

4. Hrazdan River Basin Management Area, Hrazdan River (Geghamavan Drainage Canal and Medium, Inner Currents), Kasah and Marmarik River Basins.

5. Akhuryan Basin Management Area, Metsamor, Akhuryan River Basins.

6. Northern river basin management, small rivers of Kur River, Aghstev and Debed River basins.

New norms for water quality have not been developed for Lake Sevan and Arax River. There is an uncertainty to calculate $\mathrm{BC}$ according to seasons, as well as define the $\mathrm{BC}$ for the purpose of water use.

\subsection{Water quality assessment of Debed River}

The hydrochemical observations of the Debed River were conducted in 2013-2015. The values of EWQI and AWQI were calculated according to the values of the Background Concentration [123] (Table 4.3). 
Table 4.3.

EWQI and AWQI values for Debed river, 2013, based on BC.

\begin{tabular}{|c|c|c|c|c|c|c|}
\hline \multirow{2}{*}{$\begin{array}{l}\text { Parameters } \\
\text { and } \\
\text { indicators }\end{array}$} & \multicolumn{2}{|r|}{5} & \multicolumn{2}{|r|}{6} & \multicolumn{2}{|r|}{7} \\
\hline & $\mathbf{n}$ & $n \log _{2} n$ & $\mathbf{n}$ & $n \log _{2} n$ & $\mathrm{n}$ & $n \log _{2} n$ \\
\hline DO & 2 & 2 & 2 & 2 & 2 & 2 \\
\hline $\mathrm{pH}$ & 0 & 0 & 1 & 0 & 2 & 2 \\
\hline COD & 7 & 19.64 & 9 & 28.5 & 8 & 24 \\
\hline $\mathrm{BOD}_{5}$ & 3 & 4.75 & 5 & 11.61 & 5 & 11.61 \\
\hline $\mathrm{NO}_{2}^{-}$ & 9 & 28.50 & 10 & 33.2 & 9 & 28.5 \\
\hline $\mathrm{NH}_{4}^{+}$ & 6 & 15.51 & 7 & 19.64 & 6 & 15.5 \\
\hline $\mathrm{Fe}$ & 10 & 33.20 & 12 & 43.000 & 12 & 43.000 \\
\hline $\mathrm{Cu}$ & 11 & 38.03 & 12 & 43.000 & 12 & 43.000 \\
\hline $\mathrm{V}$ & 9 & 28.5 & 10 & 33.200 & 9 & 28.500 \\
\hline $\mathrm{Al}$ & 4 & 8 & 5 & 11.61 & 6 & 15.500 \\
\hline $\mathrm{Cr}$ & 0 & 0.000 & 3 & 4.75 & 3 & 4.752 \\
\hline $\mathrm{Mn}$ & 0 & 0.000 & 2 & 2 & 4 & 8.000 \\
\hline $\mathrm{Zn}$ & 6 & 15.51 & 12 & 43.000 & 11 & 38.03 \\
\hline $\mathrm{Se}$ & 6 & 15.50 & 6 & 15.51 & 5 & 11.61 \\
\hline $\mathrm{N}$ & \multicolumn{2}{|r|}{73} & \multicolumn{2}{|r|}{96} & \multicolumn{2}{|r|}{94} \\
\hline$\sum n \log _{2} n$ & \multicolumn{2}{|c|}{209.15} & \multicolumn{2}{|c|}{291.02} & \multicolumn{2}{|c|}{276.02} \\
\hline $\mathrm{I}$ & \multicolumn{2}{|c|}{2.8650} & \multicolumn{2}{|c|}{3.0314} & \multicolumn{2}{|r|}{2.9364} \\
\hline $\mathrm{H}$ & \multicolumn{2}{|c|}{3.3212} & \multicolumn{2}{|c|}{3.5497} & \multicolumn{2}{|r|}{3.6144} \\
\hline EWQI & \multicolumn{2}{|c|}{1.1592} & \multicolumn{2}{|c|}{1.1709} & \multicolumn{2}{|r|}{1.2308} \\
\hline $\mathrm{M}=\sum \mathrm{m}$ & \multicolumn{2}{|c|}{27.9} & \multicolumn{2}{|r|}{32.7} & \multicolumn{2}{|r|}{91.0} \\
\hline$\sum \log _{2} \mathrm{M}$ & \multicolumn{2}{|c|}{4.80} & \multicolumn{2}{|r|}{5.03} & \multicolumn{2}{|r|}{6.50} \\
\hline AWQI & \multicolumn{2}{|c|}{1.6392} & \multicolumn{2}{|c|}{1.6737} & \multicolumn{2}{|r|}{1.7798} \\
\hline
\end{tabular}

The results of the Water Quality Assessment have shown that the Debed River water is classified as the 3rd, polluted and 4 th, dirty quality. With the above 4 index results, the quality of river water flows downwards gradually decreasing. If Debed River View. The water quality at 5 is the 3 rd, polluted class, and 
then it is already visible. 7 it dropped to the 4th, dirty class and the 5 th class.

Table 4.4.

Values of water quality indexes for Debed River.

\begin{tabular}{|c|c|c|c|}
\hline \multirow{2}{*}{ Indexes } & \multicolumn{3}{|c|}{ Sampling points } \\
\cline { 2 - 4 } & $\mathbf{5}$ & $\mathbf{6}$ & $\mathbf{7}$ \\
\hline $\mathrm{EWQI}_{\mathrm{MAC}}$ & 1.106 & 1.1448 & 1.1868 \\
\hline $\mathrm{EWQI}_{\mathrm{BC}}$ & 1.1592 & 1.1709 & 1.2308 \\
\hline $\mathrm{AWQI}_{\mathrm{MAC}}$ & 1.6229 & 1.6929 & 1.8929 \\
\hline $\mathrm{AWQI}_{\mathrm{BC}}$ & 1.6392 & 1.6737 & 1.7798 \\
\hline
\end{tabular}

$\mathrm{AWQI}_{\mathrm{MAC}}=-(1.509 \pm 0.0 .48)+(1.912 \pm 0.028) \cdot \mathrm{AWQI}_{\mathrm{BC}}$, $\mathrm{R}=0.99989, \mathrm{~N}=3$

$\mathrm{EWQI}_{\mathrm{MAC}}=-(0.0282 \pm 0.4258)+(0.9891 \pm 0.3586) \cdot \mathrm{EWQI}_{\mathrm{BC}}$,

$$
\mathrm{R}=0.94011, \mathrm{~N}=3
$$

Table 4.4 also shows that the indexes calculated by background concentrations are largely larger than those calculated by MAC. It turns out that the background concentrations estimated for the Debed River are much stronger than those of MAC for fish breeding.

Table 4.5

Debed River water quality by norms, 2013.

\begin{tabular}{|l|c|c|c|}
\hline \multirow{2}{*}{ Parameters } & \multicolumn{3}{|c|}{ Sampling points } \\
\cline { 2 - 4 } & $\mathbf{5}$ & $\mathbf{6}$ & $\mathbf{7}$ \\
\hline $\mathrm{DO}$ & 9.79 & 9.49 & 9.76 \\
\hline $\mathrm{pH}$ & 8.21 & 8.19 & 8.20 \\
\hline $\mathrm{BOD}_{5}$ & 2.9 & 2.9 & 3.05 \\
\hline $\mathrm{COD}$ & 12.7 & 17.7 & 20.2 \\
\hline $\mathrm{SS}$ & 48.21 & 155.3 & 114.35 \\
\hline Mineralization & 201 & 223 & 294 \\
\hline Ammonium ion & 0.264 & 0.240 & 0.301 \\
\hline Nitrate ion & 1.55 & 1.40 & 1.55 \\
\hline Nitrite ion & 0.032 & 0.032 & 0.026 \\
\hline
\end{tabular}




\begin{tabular}{|l|c|c|c|}
\hline \multirow{2}{*}{\multicolumn{1}{|c|}{ Parameters }} & \multicolumn{3}{c|}{ Sampling points } \\
\cline { 2 - 4 } & $\mathbf{5}$ & $\mathbf{6}$ & $\mathbf{7}$ \\
\hline Zinc & 0.0047 & 0.0263 & 0.1200 \\
\hline Copper & 0.0038 & 0.0137 & 0.0731 \\
\hline Chromium & 0.0010 & 0.0010 & 0.0013 \\
\hline Molybdenum & 0.0005 & 0.0006 & 0.0007 \\
\hline Manganese & 0.0150 & 0.0179 & 0.0936 \\
\hline Vanadium & 0.0068 & 0.0038 & 0.0035 \\
\hline Iron & 0.1782 & 0.3230 & 0.8530 \\
\hline Aluminum & 0.3705 & 0.3387 & 0.7001 \\
\hline Selen & 0.0017 & 0.0018 & 0.0022 \\
\hline
\end{tabular}

The water quality of the Debed River was also assessed based on appropriate WQ norms (Tables 4.5 and 4.7). Based on the results, in sampling points 5 and 6 , the water quality of the water corresponds to $1^{\text {st }}$ and $2^{\text {nd }}$ classes by vanadium and to $3^{\text {rd }}$ clasess by iron. For the 7 sampling point the main parameters water quality reduced to $4^{\text {th }}$ "unsatisfactory" class.

Table 4.6.

Debed River water quality by norms, 2014.

\begin{tabular}{|l|c|c|c|}
\hline \multirow{2}{*}{ Parameters } & \multicolumn{3}{|c|}{ Sampling points } \\
\cline { 2 - 4 } & $\mathbf{5}$ & $\mathbf{6}$ & $\mathbf{7}$ \\
\hline $\mathrm{DO}$ & 9.82 & 9.53 & 9.70 \\
\hline $\mathrm{pH}$ & 8.15 & 8.20 & 8.19 \\
\hline $\mathrm{BOD}_{5}$ & 2.7 & 2.9 & 3.15 \\
\hline $\mathrm{COD}$ & 11.8 & 16.2 & 22.1 \\
\hline $\mathrm{SS}$ & 5.4 & 5.5. & 10.4 \\
\hline Mineralization & 180 & 233 & 284 \\
\hline Ammonium ion & 0.284 & 0.340 & 0.365 \\
\hline Nitrate ion & 2.01 & 2.60 & 2.80 \\
\hline Nitrite ion & 0.041 & 0.031 & 0.031 \\
\hline Zinc & 0.0057 & 0.023 & 0.022 \\
\hline Copper & 0.0040 & 0.0180 & 0.020 \\
\hline Chromium & 0.0012 & 0.0012 & 0.0018 \\
\hline Molybdenum & 0.0011 & 0.0015 & 0.0025 \\
\hline
\end{tabular}




\begin{tabular}{|l|c|c|c|}
\hline \multirow{2}{*}{ Parameters } & \multicolumn{3}{|c|}{ Sampling points } \\
\cline { 2 - 4 } & $\mathbf{5}$ & $\mathbf{6}$ & $\mathbf{7}$ \\
\hline Manganese & 0.018 & 0.023 & 0.036 \\
\hline Vanadium & 0.004 & 0.004 & 0.004 \\
\hline Iron & 0.1782 & 0.48 & 0.50 \\
\hline Aluminum & 0.236 & 0.288 & 0.483 \\
\hline Selen & 0.0017 & 0.0018 & 0.0022 \\
\hline
\end{tabular}

The concentrations of nitrate ion and molybdenum have increased year by year. It should be noted that, depending on the particles in the Debed River, the concentration of particles, mostly concentrated in all months and at all points, exceeded the BC (Table 4.4). We recommend reviewing the dependent particle norms.

Table 4.7.

Debed River water quality by norms, 2015.

\begin{tabular}{|l|c|c|c|}
\hline \multirow{2}{*}{ Parameters } & \multicolumn{3}{c|}{ Sampling points } \\
\cline { 2 - 4 } & $\mathbf{5}$ & $\mathbf{6}$ & $\mathbf{7}$ \\
\hline $\mathrm{DO}$ & 9.82 & 9.59 & 9.79 \\
\hline $\mathrm{pH}$ & 8.18 & 8.22 & 8.24 \\
\hline $\mathrm{BOD}_{5}$ & 3.5 & 3.5 & 3.6 \\
\hline $\mathrm{COD}$ & 14.5 & 18.4 & 24 \\
\hline $\mathrm{SS}$ & 10.0 & 11.0 & 14.2 \\
\hline Mineralization & 188 & 203 & 290 \\
\hline Ammonium ion & 0.245 & 0.220 & 0.290 \\
\hline Nitrate ion & 1.75 & 2.70 & 2.60 \\
\hline Nitrite ion & 0.047 & 0.029 & 0.048 \\
\hline Zinc & 0.005 & 0.028 & 0.025 \\
\hline Copper & 0.0038 & 0.018 & 0.017 \\
\hline Chromium & 0.002 & 0.002 & 0.002 \\
\hline Molybdenum & 0.0016 & 0.0041 & 0.0055 \\
\hline Manganese & 0.023 & 0.031 & 0.04 \\
\hline Vanadium & 0.004 & 0.0039 & 0.0041 \\
\hline Iron & 0.250 & 0.3230 & 0.450 \\
\hline Aluminum & 0.340 & 0.660 & 0.788 \\
\hline Selen & 0.0017 & 0.0023 & 0.0024 \\
\hline
\end{tabular}


According to new norms, in 2013-2015 water quality of the Debed River has deteriorated, especially in the 6th and 7th sampling points, from the 2 nd and 3 rd water quality classes to the 4 th more polluted class.

\subsection{Europian water quality indexes with biological content}

\subsubsection{Hulberts diversity index (ES100)}

Hurlberts index is based on the rarefaction technique of Sanders. The expected number of species (ES) is calculated among a certain number of individuals, individuals e.g. 100 individuals (ES100). The index was calculated according to the formula:

$$
E S_{100}=\sum_{i=1}^{S} 1-\frac{\left[\frac{\left(N-N_{i}\right) !}{\left(N-N_{i}-100\right) ! 100 !}\right]}{\left[\frac{N !}{(N-100) ! 100 !}\right]},
$$

where $\mathrm{ES}_{100}=$ expected number of species among 100 randomly chosen individuals in a sample with $\mathrm{N}$ individuals, $\mathrm{S}$ species and individuals of the ith species [45].

\subsubsection{ISI sensitivity index}

ISI is a sensitivity index which uses the occurrence or absence of indicator species to measure stress levels (e.g. pollution impact). Species which frequently occur in highdiversity samples, but not in low diversity samples, are classified as sensitive species. The presence of many sensitive species in a community indicates a healthy environment. The sensitivity value for each of the 200 taxa was determined by 
obtaining the five lowest ES100 values for the taxon in question among all samples where this taxon occurred, and calculating the average of these 5 values. The average of the 5 lowest ES100 was defined as the sensitivity value of the taxon and referred to as ES100 .The sensivity values can be found in. The development of these values was based on data from 1080 samples from Norwegian soft-bottom fauna, collected between 1975 and 2001.

The index was calculated according to the formula

$$
I S I=\frac{\left(E S_{100 \min 5}-E S_{100 \min 5 i}\right)}{N},
$$

where the index value of a sample is defined as the average of sensitivity values (ES100) of taxa occurring in the sample. Taxa/species which occur in the sample, but have no sensitivity values assigned to them, are ignored in the calculation of ISI. Only presents/absence data of the taxa, not their abundance is considered. Additional species belonging to the same taxon are ignored [126].

\subsubsection{The Applied Marine Biotic Index (AMBI)}

The AMBI index is commonly used as element in multimetric indices. The index establishes a disturbance classification according to 5 ecological groups (EG) of species:

Group I "Species very sensitive to organic enrichment and present under polluted conditions (Initial state)".

Group II "Species indifferent to organic enrichment, always present in low densities with non-significant variations over time (from initial state to slight unbalanced)". 
Group III "Species tolerant to excess organic matter enrichment. These species may occur under normal conditions, but their populations are stimulated by organic enrichment (slight unbalanced situations)."

Group IV "Second order opportunistic species (slight to pronounced unbalanced situations), mainly small sized polychaetes."

Group V "First-order opportunistic species (pronounced unbalanced situation)".

The AMBI index was calculated using AMBI version 4.0 (www.azti.es) according to the formula

$$
A B I=\frac{[(0 \times \% G I)+(1.5 \times \% G I I)+(3 \times \% G I I I)+(4.5 \times \% G I V)+(6 \times \%) G V]}{100},
$$

where GI- GV corresponds to group 1 to 5 listed above. \%G indicates the percentage of the total number of species belonging to this group. The AMBI index increase with the level of disturbance, a value of 0 represents the highest obtainable status, while a status below 6 is characterized as azoic [126-129].

\subsubsection{Norwegian quality index version 1 (NQI1)}

The official index for the WFD in Norway is the NQI1, which is intercalibrated with the other indices in the NEAGIG. It is a multimetric index which includes AMBI as a measure of sensitivity and the diversity component is described by a factor SN [8]. Both AMBI and SN are normalised to attain values between 0 and 1 . The diversity component is modified by a factor to compensate for low densities. The normalised sensitivity and diversity components are weighted equally. 
The index was calculated according to the formula

$$
N Q I 1=\left[0.5 \times\left(1-\frac{A M B I}{7}\right)+0.5 \times\left(\frac{S N}{2.7}\right) \times\left(\frac{N}{N+S}\right)\right],
$$

where, $\mathrm{SN}=\ln \mathrm{S} / \ln (\ln \mathrm{N}), \mathrm{S}$ is number of species and $\mathrm{N}$ is number of individuals [130-132].

\subsubsection{The Norwegian quality index version 2 (NQI2)}

NQI2 is identical to NQI1 except the diversity component consists of Shannon diversity $(\mathrm{H})$ which is normalised to attain values between 0 and 1 . The normalised sensitivity and diversity components are weighted equally [130-132].

The equation is:

$$
N Q I 2=\left[0.5 \times\left(1-\frac{A M B I}{7}\right)+0.5 \times\left(\frac{H}{6}\right)\right],
$$

\subsubsection{The Danis index (DKI)}

The Danish index (DKI) is a multimetric index consisting of a sensitivity component (AMBI), a diversity component (Shannon diversity) and a factor including species number and number of individuals to compensate for low densities and species numbers. The diversity component $(\mathrm{H})$ and the sensitivity component (AMBI) are both normalised to attain a value between 0 and 1 , and the diversity is normalised against the highest diversity observed in the area . As the area did not include any undisturbed sites, $\mathrm{H}$ max was set to 5 following. All variables are weighted equally in this approach.

The index was calculated according to the formula: 


$$
D K I=\left[\frac{\left(1-\frac{A M B I}{7}\right)+\left(\frac{H}{H \max }\right)}{2}\right] \times\left[\frac{\left(1-\frac{1}{N}\right)+\left(1-\frac{1}{S}\right)}{2}\right],
$$

where $\mathrm{H}$ is the Shannon index with log base 2, and $\mathrm{H}$ max is the highest value that $\mathrm{H}$ reaches in undisturbed condition, $\mathrm{S}$ is the number of taxa and $\mathrm{N}$ is the number of individuals in the sample. DKI can attain values between 0 and 1 . If $\mathrm{S}=1$ and $\mathrm{N}=1$ then DKI=0. 29 [127].

\subsubsection{Infaunal quality index (IQI)}

The IQI index (Dr. A. Miles, Environmental agency, Peterborough, UK, version 1, still undergoing development, unpublished) is used in UK and Ireland. It is a multimetric index, which consists of the sensitivity element (AMBI), a diversity element (Simpsons index) and a factor including number of taxa and number of individuals. The index was calculated according to the formula

$$
I Q I=\left[\frac{\left(1-\frac{A M B I}{7}\right)+(1-\lambda)}{3}\right] \times\left[\frac{\left(1-\frac{1}{N}\right)+\left(1-\frac{1}{S}\right)}{2}\right],
$$

where is Simpsons index, $\mathrm{S}$ is the number of taxa and $\mathrm{N}$ is the number individuals [127].

\subsubsection{Benthic quality index (BQI )}

The Swedish index (BQI) is a multimetric index. The sensitivity element of the index is like in the ISI index based on Hulberts diversity index. However, ES50 is used instead of ES100 to enable the use of samples with abundances between 50 and 100 , which is useful in disturbed areas. The most tolerant 
species are likely to be associated with the lowest ES50 values selected that $5 \%$ of the population would be associated to this category, and defined this value as the species tolerance value . As sensitivity values were calculated both based on Swedish and Norwegian faunistic data, the index was calculated separately for the two types of sensitivity. The indices were denoted BQIs for Swedish values and BQIn for Norwegian values.

The index was calculated according to the formula:

$$
B G I=\left[\sum_{i=1}^{n}\left(\frac{A_{i}}{\operatorname{tot} A} \times E S 50_{0.50 i}\right)\right] \times \log _{10}(S+1) \times\left(\frac{N}{N+S}\right),
$$

where is the abundance of individuals of species $i$ at the considered station, is the sum of the abundance of individuals of all species for which it is possible to compute an , is of species, $\mathrm{S}$ is the total number of species at the considered station and $\mathrm{N}$ is the total number of individuals. 30 The tolerance value ( of each species found at a stations is multiplied with the mean relative abundance (A) of species to put weight on common species in relation to rare species. Furthermore, the sum is multiplied with a 10 logarithm for 1 plus the number of species (S) at the station, as high species diversity is related to high environmental quality [133].

\subsubsection{Benthic habitat quality index (BHQ)}

The Benthic habitat quality index (BHQ) is founded on the principles of Pearson and Rosenberg model of benthic succession along a gradient of pollution. The index is calculated using information obtained from the SPI pictures. Information on sediment habitat structures like tubes, burrows, voids, pits 
and mounds are along with the depth of the RPD layer summarized into an index that provides information on benthic habitat quality. Biogenic structures caused by activities of the fauna on sediment surface, within sediment and the mean vertical depth distribution of the RPD layer are all given a score between 0 and 5 resulting in an index that ranges between 0 and 15. In order to assess EcoQ according to the EU Water Framework Directive the index is divided into 5 groups.

The index was calculated according to the formula:

$$
B H Q=\sum A+\sum B+C,
$$

where $\mathrm{A}$ is surface structures, B IS subsurface structures and C IS mean sediment depth of apparent redox potential discontinuity (RPD) layer [134-135].

Table 4.1.

Reference values and class boundaries for all investigated indices.

\begin{tabular}{|c|c|c|c|c|c|c|}
\hline \multirow{2}{*}{$\begin{array}{c}\text { Indicative } \\
\text { parameter }\end{array}$} & \multirow{2}{*}{$\begin{array}{c}\text { Reference } \\
\text { value }\end{array}$} & \multicolumn{5}{|c|}{ Ecological classes } \\
\cline { 3 - 7 } & & $\begin{array}{c}\text { Very } \\
\text { good }\end{array}$ & Good & Moderate & Poor & High \\
\hline NQI1 & 0.78 & $>0.72$ & $\begin{array}{c}0.72- \\
0.63\end{array}$ & $0.63-0.49$ & $\begin{array}{c}0.49- \\
0.31\end{array}$ & $<0.31$ \\
\hline NQI2 & 0.73 & $>0.65$ & $\begin{array}{c}0.65- \\
0.54\end{array}$ & $0.54-0.38$ & $\begin{array}{c}0.38- \\
0.20\end{array}$ & $<0.20$ \\
\hline H & 4.4 & $>3.8$ & $3.8-3.0$ & $3.0-1.9$ & $\begin{array}{c}1.9- \\
0.9\end{array}$ & $<0.9$ \\
\hline ES100 & 3.2 & $>25$ & $25-17$ & $17-10$ & $10-0.5$ & $<0.5$ \\
\hline ISI & 9.0 & $>8.4$ & $8.4-7.5$ & $7.5-6.1$ & $6.1-$ & $<4.2$ \\
& & & & & 4.2 & \\
\hline IQI & N.A. & $>0.75$ & $0.75-$ & $0.63-0.41$ & $0.41-$ & $<0.20$ \\
& & & 0.63 & & 0.20 & \\
\hline BQI & 20 & $>16$ & $16-12$ & $12-8$ & $8-4$ & $<4$ \\
\hline DKI & $\mathrm{H}_{\max }(5)$ & $>0.72$ & $0.72-$ & $0.58-0.35$ & $0.35-$ & $<0.16$ \\
& & & 0.0 .58 & & 0.16 & \\
\hline BHQ & 15 & $15-11$ & $11-7$ & $7-4$ & $4-2$ & $2-0$ \\
\hline
\end{tabular}




\subsubsection{Denisenko Index}

Denisenko uses the information concept of Shannon to propose a new assessment of the ecological well-being of the marine zoo - $\mathrm{D}_{\mathrm{E}}$ (difference in the evenness).

$$
D_{E}=\frac{H_{1}-H_{2}}{\log _{2} N},
$$

where $H_{1}$ is the Shannon index calculated from the biomass, $H_{2}$ is the Shannon index, calculated by the number of individuals, and $N$ is the number of species [136]. 


\section{Chapter 5. Analyses of the ecological systems by geoecological evolving organized index}

\subsection{Analysis of the biopolymers}

In biological systems, there can be processes both with recovery and decrease in entropy. The concept of entropy has many interpretations in the most diverse areas of human knowledge. Along with the entropy of Clausius, static, informational, mathematical, linguistic, intellectual and other entropies appeared. Entropy became the basic concept of information theory and began to act as a measure of the uncertainty of a certain situation. To characterize the measure of the complexity of the system, U. Ashby first proposed the use of the concept of entropy. The system interacts with the outside world as a whole. In general, the system does not lose its organization or high orderliness. Open systems can exchange energy, matter and, last but not least, information with surrounding bodies. For a biological system to act and interact with the environment, it must consume information from the environment and communicate information to the environment. This process is called information metabolism, which, together with the material and material metabolism, forms a complete metabolism.

For the first time, in 1955, Mac-Arthur [137] used the general Shannon entropy equation for estimating the degree of structuring of biocenoses, in which pi was replaced by $\mathrm{pi}=\mathrm{ni} /$ $\mathrm{N}$; (where ni is the total number of individuals of the species $\mathrm{i}$, $\mathrm{N}$ is the total number of individuals in the entire biocenosis). In 
1957, R. Margalef postulated a theoretical concept according to which diversity corresponds to entropy when randomly choosing species from the community $[138,139]$. As a result of these works, the Shannon H Index, sometimes called the Shannon Diversity Information Index, has gained widespread acceptance.

The use of the Shannon diversity index in ecology and, in particular, fot assess the degree of structuring of populations and biocenoses is discussed in great detail. The features of the functioning of biological systems of different levels from the point of view of information theory were also considered in. Schmalhausen introduced the concepts of direct and feedback channels through which genetic and phenotypic information is transmitted, and the laws governing the transformation and coding of biological information [140].

An open system is a system that constantly exchanges matter and energy with the environment. A high degree of orderliness of an open system is achieved by increasing the entropy outside it.

Living organisms are formed from all sorts of small organic molecules - monomers, which when combined create macromolecules. The unity of the living at the molecular level is expressed primarily in the presence of two types of vital polymers - nucleic acids containing genetic information from all organic forms, without exception, and proteins, which are the basis of the construction and all vital signs of any living being. Self-regulation and self-reproduction of a biological system are based on the properties of its constituent proteins and nucleic acids. Proteins are organic compounds that make up all living organisms, consisting of a large number of monomers. The 
composition of proteins includes 20 standard amino acids. Properties of proteins are determined by the spatial threedimensional structure of their chains. By changing only one amino acid in the chain, you can get a molecule with a completely different structure and other properties. The huge variety of living organisms on our planet is determined by differences in the composition and spatial form of the proteins that make them up. Nucleotides are monomeric units of a chain of nucleic acids. They are chemical compounds of residues of three substances: nitrogenous base, carbohydrate and phosphoric acid. There are two types of nucleic acids - deoxyribonucleic acid (DNA) and ribonucleic acid (RNA). DNA contains genetic information about the sequence of amino acids in polypeptide chains and determines the structure of proteins. RNA is responsible for making proteins. It turned out that the DNA molecule consists of two monomer chains running in opposite directions and spirally twisted one around the other. The DNA of the entire organic world is formed by the combination of four types of nucleotides - adenine (A), guanine (G), cytosine (C) and thymine (T), their location in the DNA molecule gives an indication to the RNA molecule how to build a protein. RNA molecule single-stranded. The structure of RNA is also created by alternating four types of nucleotides, but their composition is slightly different from the composition of those in DNA molecules in that uracil (U) is used instead of thymine (T).

The concept of structural levels of living organisms allows to arrange them in a hierarchical subordination. According to the criterion of scale, the biological level includes sublevels: macromolecules (nucleic acids, DNA, RNA, proteins), cell 
levels, microorganic (single-cell organisms), organs and tissues of organisms in general, population, biocenosis and biosphere.In accordance with the purpose of the work and the formulation of the problem, calculations were made of the function of protein molecules, RNA, DNA and the living body [141, 142].

The elements of the system can be amino acids in a protein molecule, nucleocytes in RNA and DNA molecules, as well as the elemental composition of biopolymers and organisms.

The primary structures of protein molecules, RNA and DNA are, respectively, sequences of amino acid residues and nucleotides, and can be considered as systems divided into parts according to the same types of corresponding amino acids and nucleotides. For example, the primary structure of the corticotropin molecule is as follows:

Ser- Tyr- Ser- Met-Glu- His- Phe- Arg-Trp-Gly-lys-Pro-ValGly-Lys-Lys-Arg-Arg-Pro-Val-Lys-Val-Tyr-Pro-Asp-Ala-GlyGlu-Asp-Gln-Ser-Ala-Glu-Ala-Phe-Pro-Leu-Glu-Phe

Table 5.1.

The calculation of the values of $I, H$ and $G$ in the structure of the molecule corticotropin.

\begin{tabular}{|c|c|c|c|c|c|c|c|}
\hline № & $\begin{array}{c}\text { Amino } \\
\text { acid }\end{array}$ & $\mathbf{n}$ & $\mathbf{n l o g} \mathbf{2}$ & № & $\begin{array}{c}\text { Amino } \\
\text { acid }\end{array}$ & $\mathbf{n}$ & $\mathbf{n l o g}_{2} \mathbf{n}$ \\
\hline 1 & Gly & 3 & 4.75 & 9 & Leu & 1 & 0 \\
\hline 2 & Ala & 3 & 4.75 & 10 & Phe & 3 & 4.75 \\
\hline 3 & Val & 3 & 4.75 & 11 & Tyr & 2 & 2 \\
\hline 4 & Lys & 4 & 8 & 12 & Asp & 2 & 2 \\
\hline 5 & His & 1 & 0 & 13 & Gln- & 1 & 0 \\
\hline 6 & Met & 1 & 0 & 14 & Trp & 1 & 0 \\
\hline 7 & Glu & 4 & 8 & 15 & Ser & 3 & 4.75 \\
\hline 8 & Arg & 3 & 4.75 & 16 & Pro & 4 & 8 \\
\hline \multicolumn{7}{|c|}{$\mathrm{N}=39 \sum \log _{2} \mathrm{n}=56.5$} \\
I $=56.5: 39=1.46 \mathrm{H}=\log _{2} 39-1.948=3.82$ \\
G $3.82: 1.46=2.61$ \\
\hline
\end{tabular}


Table 5.2 gives the $\mathrm{I}, \mathrm{H}$, and $\mathrm{G}$ values for protein molecules.

For corticotropin $\mathrm{N}=39$, the number of nucleic acids is 16 , and the number of identical residues (n) varies from 1 to 4 . The corresponding calculations of functions I, $\mathrm{H}$, and $\mathrm{G}$ are shown in Table 5.1, which implies that the corticotropin chain is a chaotic type of system.

Table 5.2.

The values of $\mathrm{N}, \mathrm{I}, \mathrm{H}$ and $\mathrm{G}$ of protein molecules.

\begin{tabular}{|c|c|c|c|c|}
\hline Protein molecules & $\begin{array}{c}\mathbf{N} \\
{[\mathbf{1 4 1}]}\end{array}$ & $\mathbf{I}$ & $\mathbf{H}$ & $\mathbf{G}$ \\
\hline Glycogen phosphorylase & 841 & 5,54 & 4.18 & 0.75 \\
\hline Thrombin & 259 & 3,81 & 4.21 & 1.10 \\
\hline Luteinizing hormone & 205 & 3,57 & 4.11 & 1.15 \\
\hline Myoglobin & 152 & 3,30 & 3.95 & 1.20 \\
\hline Cytochrome c & 104 & 2,75 & 3.95 & 1.74 \\
\hline Corticotropin & 39 & 1,46 & 3.82 & 2.61 \\
\hline Glucagon & 29 & 1,14 & 3.75 & 3.29 \\
\hline
\end{tabular}

Tables 5.1 and 5.2 show that the amino acid chains of glucagon and corticotropin citrochrome have an obvious chaotic structure $(G>1)$. The chains of all other protein molecules belong to the synergistic type of systems and tend to decrease and approach $\mathrm{G}=1$ as the total number of amino acid residues in the protein chain grows.

Based on the statistical data of the HIVH3CG virus genome [124], it is shown how for RNA $G=0.8$, then order prevails in the structure of the system (Table 5.3). 
Table 5.3.

The nucleotide composition, mol. \%, Calculation of the I, $\mathbf{H}$ and $\mathbf{G}$ genome of the virus (HIVH3CG).

\begin{tabular}{|c|c|c|}
\hline Nucleotides & $\mathbf{n}$ & $\mathbf{n} \log _{2} \mathbf{n}$ \\
\hline $\mathrm{U}$ & 22.23. & 99.41 \\
\hline $\mathrm{C}$ & 18.32 & 76.81 \\
\hline $\mathrm{A}$ & 35.20 & 180.73 \\
\hline $\mathrm{G}$ & 24.25 & 111.48 \\
\hline \multicolumn{2}{|c|}{$\mathrm{I}=\sum \operatorname{nog}_{2} \mathrm{n}: \mathrm{N}=368.4: 100=3.684$} \\
$\mathrm{H}=\log _{2} \mathrm{~N}-\mathrm{I}=\log _{2} 100-3.684=2.956$ \\
$\mathrm{G}=\mathrm{H} / \mathrm{I}=2.956: 3.684=0.803$ \\
\hline
\end{tabular}

Table 5.4 shows some statistical data on the nucleotide composition of DNA and calculated data I, H and G of different organisms from viruses to humans.

Table 5.4.

The nucleotide composition, mol\%. Calculation of I, $\mathrm{H}$ and $\mathrm{G}$ DNA From.

\begin{tabular}{|c|c|c|c|c|c|c|c|}
\hline Organism & $\begin{array}{c}\mathbf{A , \%} \\
\mathbf{m o l}\end{array}$ & $\begin{array}{c}\mathbf{G , \%} \\
\mathbf{m o l}\end{array}$ & $\begin{array}{c}\mathbf{T , \%} \\
\mathbf{m o l}\end{array}$ & $\begin{array}{c}\mathbf{C}, \boldsymbol{\%} \\
\mathbf{m o l}\end{array}$ & $\mathbf{H}$ & $\mathbf{I}$ & $\mathbf{G}$ \\
\hline Human & 30.9 & 19.9 & 29.4 & 19.8 & 1.97 & 4.67 & 0.422 \\
\hline Sheep & 29.3 & 21.4 & 28.3 & 21.0 & 1.98 & 4.66 & 0.425 \\
\hline Hen & 28.8 & 20.5 & 29.2 & 21.5 & 1.98 & 4.66 & 0.425 \\
\hline Turtle & 29.7 & 22.1 & 27.9 & 21.3 & 1.92 & 4.72 & 0.434 \\
\hline Salmon & 29.7 & 20.8 & 29.1 & 20.4 & 1.98 & 4.66 & 0.425 \\
\hline Sea urchin & 32.8 & 17.7 & 32.1 & 17.3 & 1.94 & 4.70 & 0.414 \\
\hline Locust & 29.3 & 20.5 & 29.3 & 20.7 & 1.87 & 4.77 & 0.390 \\
\hline Wheat & 27.3 & 22.7 & 27.1 & 22.8 & 2.00 & 4.64 & 0.431 \\
\hline Yeast & 31.3 & 18.7 & 32.9 & 17.1 & 1.94 & 4.70 & 0.414 \\
\hline $\begin{array}{c}\text { Eschericha coli } \\
\text { (bacterium) }\end{array}$ & 24.7 & 26.0 & 23.6 & 25.7 & 2.00 & 4.64 & 0.431 \\
\hline $\begin{array}{c}\text { Bacteriophage } \\
\text { X 174 (virus) }\end{array}$ & 24.6 & 24.1 & 32.7 & 18.5 & 1.97 & 4.67 & 0.422 \\
\hline
\end{tabular}

From table 5.4 it is clear that for DNA of different organisms $G=0.420$, which indicates that the structure of the DNA molecules is clearly ordered. 
Dizoxyribonucleic acid, like any chemical compound, has the formula, while DNA is a polymer and, like any polymer, its formula is very unambiguous for DNA. The number of nucleotides in each monomer is different, but in the same segment of DNA they are the same, the number of segments can reach 100,000. Thus, the simplified (non-structural) DNA formula of an animal cell consisting of 100,000 segments is as follows:

\section{$\left\{\left[\left(\mathrm{C}_{5} \mathrm{H}_{10} \mathrm{O}_{4}\right)_{4}-\left(\mathrm{PO}(\mathrm{OH})_{3}\right)_{4}-\mathrm{C}_{4} \mathrm{H}_{3} \mathrm{~N}_{3} \mathrm{O}-\mathrm{C}_{5} \mathrm{H}_{4} \mathrm{~N}_{5} \mathrm{O}-\mathrm{C}_{5} \mathrm{H}_{5} \mathrm{~N}_{2} \mathrm{O}_{2}-\right.\right.$ $\left.\left.\mathrm{C}_{5} \mathrm{H}_{3} \mathrm{~N}_{5}\right] 100000\right\}_{2}$}

A completely simplified formula is as follows: $\left(\mathrm{C}_{78} \mathrm{H}_{134} \mathrm{P}_{8} \mathbf{N}_{30} \mathbf{O}_{70}\right) \mathbf{1 0 0 0 0 0}$.

In Table 5.5 we give the elemental chemical composition of DNA. From Table 5.5 it is clear that based on the elemental composition of the DNA, the entropy index is also obtained on the order of $\mathrm{G}=0.420$.

In the cells of living systems many of the chemical elements present in the environment exsits, but only about 20 of them are necessary for life. These elements are called biogenic. On average, about $70 \%$ of the mass of organisms is oxygen, $18 \%$ is carbon, $10 \%$ is hydrogen and $2 \%$ of the remaining elements (nitrogen, phosphorus, potassium, calcium, sulfur, etc.).

Table 5.5.

The elemental composition, mol $\%$ and calculation of $\mathrm{I}, \mathrm{H}$ and $\mathrm{G}$ DNA.

\begin{tabular}{|c|c|c|}
\hline Elements mol \% & n & $\mathbf{n l o g}_{2} \mathbf{n}$ \\
\hline $\mathrm{C}$ & 24.38 & 111.72 \\
\hline $\mathrm{H}$ & 41.87 & 225.46 \\
\hline $\mathrm{O}$ & 21.88 & 97.34 \\
\hline $\mathrm{N}$ & 9.37 & 30.23 \\
\hline $\mathrm{P}$ & 2.5 & 3.30 \\
\hline \multicolumn{2}{|c|}{$\mathrm{I}=\Sigma \log _{2} \mathrm{n}: \mathrm{N}=468.05: 100=4.68$} \\
$\mathrm{H}=\log _{2} \mathrm{~N}-\mathrm{I}=\log _{2} 100-4.68=1.96$ \\
$\mathrm{G}=\mathrm{H} / \mathrm{I}=1.96: 4.68=0.41888$ \\
\hline
\end{tabular}


Table 5.6

The elemental composition, $\% \mathrm{~mol}$ and $\mathrm{p}$ calculation of $\mathrm{I}, \mathrm{H}$ and

\begin{tabular}{|c|c|c|c|c|}
\hline Elements & $\mathbf{C}$ & $\mathbf{H}$ & $\mathbf{O}$ & $\mathbf{N}$ \\
\hline $\mathbf{n}$ & 18 & 10 & 70 & 2 \\
\hline $\mathbf{n l o g}_{2} \mathbf{n}$ & 75.0 & 33.2 & 428.8 & 2 \\
\hline \multicolumn{5}{c}{$\mathrm{I}=\Sigma \mathrm{nlog}_{2} \mathrm{n}: \mathrm{N}=539: 100=5.39$} \\
$\mathrm{H}=\log _{2} \mathrm{~N}-\mathrm{I}=\log _{2} 100-5.39=1.25$ \\
$\mathrm{G}=\mathrm{H} / \mathrm{I}=1.25: 5.39=0.232$ \\
\hline
\end{tabular}

Thus, for the first time, a structural analysis of the state of biological systems at the level of proteins, ribonucleic acid, DNA and cells was carried out using the entropy index. It has been established that in the series: protein $\rightarrow$ RNA $\rightarrow$ DNA $\rightarrow$ cell, entropy decreases, and Gevsim syntropia increases, and $\mathrm{G}$ function decreases. For protein $\mathrm{G}$, the function tends to unity, which indicates that the structural organization of the system is equilibrium. It was shown that for DNA of different organisms $\mathrm{G}=0.420$, which indicates that the structure of DNA molecules has an explicit order. For a cell $\mathrm{G}<0.2$, which indicates a high degree of freedom and order of these systems[143].

\subsection{Analysis of environmental status of wood and shrub vegetation by the Armenian index of Environmental quality}

Green plantings of the city, performing their sanitary and hygienic and decorative functions, are designed to create comfortable or close to such conditions, habitat for the population. Factors of adverse effects on urban ecosystems act in a complex, having a permanent negative impact on the vital activity of plants in urban environments and leading to the 
premature death of trees, long before the onset of natural old age. The system of monitoring the state of green plantations is built on the inventory of green spaces and annual monitoring of their condition, which allows to reliably estimate the dynamics of plantation status, analyse the results obtained, and make forecasts for the future. Monitoring data on the presence of dead trees are taken into account for planning the amount of work on sanitary felling of trees by organizations involved in the maintenance of green spaces [144-150].

The purpose of the work is to assess the ecological state of wood and vegetation using the indices Geo-Ecological Evolving Organised (G) and Armenian index of environmental quality (A) obtained from the Shenon index $[87,88]$. Proceeding from the aim of the investigation, the assessment of the state of green plantations on the territory of the Kazakh Agrotechnical University (KAU), located in Saryarkinsky district and Ijevan arboretum of Tavush Marz of Armenia.

Study area.

(a) Planting plantations on the territory of the KAU cover the following types of green areas: boulevards, squares, street plantings. They are located on three sections: the first is between the streets of Moldagulova, Shakarim and the avenue Zhenis, the second one between the streets of Shakarim, Esenberlin and Zhenis avenue, and the third is between Moldagulova, Beibitshilik, Shakarima, Esenberlin streets. On the green areas KAU are 23 species of trees and shrubs. Total count of plants is 3463 , of which conifers: spruce and spruce pine are 110 pieces, deciduous - 3353 pieces. 
(b) Ijevan Dendrological Park is located in Ijevan in the north-eastern part of Armenia. The arboretum is 630-650 m above sea level, on the right bank of the river Agstev. The arboretum consists of two zones: the Ijevo arboretum 8.5 hectares and the pitoma zone 6.0 ha. In the arboretum were tested 1000 species of trees and shrubs from introduced from the areas of many countries in the world. In the arboretum there are 640 species of trees and shrubs[145].

Prosedure for determining diversity index. Studies of green plantations in the investigated object were carried out in accordance with the accepted method, trees were assessed on a four-point scale - 'good', 'satisfactory', 'unsatisfactory' and 'emergency'.

I - good trees of the state (signs of weakening);

II - trees of a satisfactory condition (weakened);

III - trees of unsatisfactory condition (strongly weakened, shrinking trees).

IV - emergency state tree. plants recommended for removal (felling)

The analysis of the ecological state of woody and shrubby vegetation is made using the following categories, biodiversity indices and and environmental quality indices.

Weighted average category of plants

$$
K=\frac{\left(n_{1} \times 1.0+n_{2} \times 2.0+n_{3} \times 3.0\right)}{N},
$$

where $n_{1}, n_{2}$, and $n_{3}$ are the corresponding numbers of trees of I, II, III categories, and $N$ - the total number of trees[146].

The Shannon diversity index. The concept of entropy has many interpretations in various fields of human knowledge. The 
system interacts with the outside world as a whole. An open system can exchange energy, material and, which is not less important, information with environment. The system consumes information from the environment and provides information to environment for act and interact with environment. Shannon was the first who related concepts of entropy and information[87,88]. He has suggested that entropy is the amount of information attributable to one basic message source, generating statistically independent reports. Get any amount of information entropy is equal to the lost. Information entropy for independent random event $x$ with $N$ possible states is calculated by the following equation:

$$
\mathrm{H}=-\sum_{\mathrm{i}=1}^{\mathrm{N}} \mathrm{p}_{\mathrm{i}} \log _{2} \mathrm{p}_{\mathrm{i}},
$$

where $P_{i}$ is the probability of frequency of occurrence of an event.

The entropy of Shenon or the Shannon diversity Index (the Shannon Index) has become a popular index of diversity in environmental literature after the 1955 article by Robert Helmer MacArthur, who used the Shenon equations to assess the degree of structuring of biocenoses [137]. Margalef postulated theoretical concept that meets a variety of entropy for a random selection of species from the community[138,139]. When calculating the diversity of biocenoses, the value expressing the amount of information per element (individual, unit of biomass, etc.) is denoted by:

$$
H=-\sum_{i=1}^{S} \frac{n_{i}}{N} \log _{2} \frac{n_{i}}{N} .
$$

The information of the whole biocenosis or its part in a unit of space (volume, area), equal to the product of $H$ by the total 
number of elements in the biocenosis $(\mathrm{N}) ; n_{i}$ - the number of elements in this group; $S$ - the number of groups. The number of elements can be understood as the number of individuals, their biomass and any other characteristics of the groups. Thus, according to MacArthur 'The variety in the Shannon index is treated as the amount of information per species that is enclosed in distributions by species, individuals, or energy over trophic connections'.

The Simpson diversity indices. The term 'Simpson's Diversity Index' can actually refer to any one of 3 closely related indices:

$$
\mathrm{D}=\frac{\sum \mathrm{n}(\mathrm{n}-1)}{\mathrm{N}(\mathrm{N}-1)},
$$

where $n$ is the the total number of organisms of a particular species; $N$ - the total number of organisms of all species The value of $\mathrm{D}$ ranges between 0 and 1 [147].

The Gini-Simpson index of Diversity $1-\mathrm{D}$. The value of this index also ranges between 0 and 1, but now, the greater the value, the greater the sample diversity. This makes more sense.

The Simpson Reciprocal Index 1/D. This measure is also known in ecology as the probability of interspecific encounter and the Gini-Simpson index. It can be expressed as a transformation of true diversity of order 2. The most popular of such indices have been the inverse Simpson index (1/D) and the Gini-Simpson index (1 - D) $[148,149]$.

Based on detailed surveys of green plantations in 20152016 in the territory of the main building of KAU for accounting, assessment and status, biometric measurements, interpolation and statistical processing field material developed 
scientific approaches to the creation and reconstruction of green spaces. Landscaping plantations on the territory of the university were surveyed, covering the following types of green areas: boulevards, squares, street plantings. Table 5.7 presents data on the distribution of KAU woody vegetation by categories. With the help of these data, the calculation of the indices diversiti (Table 5.8).

Table 5.7.

Distribution of woody vegetation KAU by category.

\begin{tabular}{|l|c|c|c|c|c|}
\hline \multirow{2}{*}{$\begin{array}{c}\text { Number, pcs. } \\
\text { Name of the plant }\end{array}$} & \multicolumn{2}{|c|}{ Status category code } & \multirow{2}{*}{ Total } & \multirow{2}{*}{ Emergency } \\
\cline { 2 - 4 } & I & II & III & & \\
\hline Ulmus pumila & 949 & 767 & 148 & 1883 & 79 \\
\hline Acer negundo & 152 & 171 & 113 & 436 & 63 \\
\hline Populus balsamifera & 124 & 39 & 8 & 171 & 286 \\
\hline Malus baccata & 86 & 80 & 6 & 172 & 17 \\
\hline Caragana arborescens & 90 & 7 & 1 & 97 & 6 \\
\hline Betula pendula & 35 & 28 & - & 63 & 5 \\
\hline Salix fragilis & 40 & 16 & - & 56 & 4 \\
\hline Pinus sylvestris & 6 & 45 & 7 & 58 & 2 \\
\hline Syringa vulgaris & 26 & 3 & 1 & 30 & 2 \\
\hline Sorbus aucuparia & 24 & 2 & - & 26 & 1 \\
\hline
\end{tabular}

Table 5.8.

Values of diversity indices of plants on the territory of the KAU.

\begin{tabular}{|l|c|c|c|c|c|c|c|}
\hline $\begin{array}{c}\text { Name of the } \\
\text { plant }\end{array}$ & H & D & $\mathbf{1 - D}$ & $\mathbf{1 / D}$ & $\mathbf{G}$ & $\mathbf{A}$ & $\mathbf{K}$ \\
\hline Ulmus pumila & 1.42 & 0.4258 & 0.5742 & 2.3485 & 0.1502 & 0.7802 & 1.55 \\
\hline Acer negundo & 1.61 & 0.3379 & 0.6620 & 2.9593 & 0.2242 & 0.8218 & 1.91 \\
\hline $\begin{array}{l}\text { Populus } \\
\text { balsamifera }\end{array}$ & 1.03 & 0.5776 & 0.4224 & 1.7314 & 0.162 & 0.9775 & 1.32 \\
\hline Malus baccata & 1.18 & 0.4644 & 0.5366 & 2.1531 & 0.1891 & 0.5976 & 1.46 \\
\hline $\begin{array}{l}\text { Caragana } \\
\text { arborescens }\end{array}$ & 0.45 & 0.8470 & 0.1530 & 1.1805 & 0.073 & 0.3313 & 1.07 \\
\hline Betula pendula & 0.994 & 0.4966 & 0.5033 & 2.0134 & 0.1995 & 0.4315 & 1.44 \\
\hline Salix fragilis & 0.834 & 0.5844 & 0.4166 & 1.711 & 0.1738 & 0.3738 & 1.28 \\
\hline Pinus sylvestris & 0.994 & 0.6207 & 0.3793 & 1.6111 & 0.2046 & 0.3046 & 2.01 \\
\hline Syringa vulgaris & 0.675 & 0.754 & 0.264 & 1.3262 & 0.1596 & 0.2596 & 1.17 \\
\hline Sorbus aucuparia & 0.391 & 0.8523 & 0.1477 & 1.173 & 0.0907 & 0.0907 & 1.08 \\
\hline
\end{tabular}


For example, for Malus baccata, the number of trees in categories I, II and III is 86,80 and 6, respectively. The total number of trees is $N=172, \sum n \log _{2} \mathrm{n}=552.3+505.5+15.5=$ 1073.3, $\mathrm{I}=1073.3 / 172=6.24, \mathrm{H}=\log _{2} 172-6.24=7.42-6.24$ $=1.18, G=1.18 / 6.24=0.1891$. The total number of emergency trees is $M=\Sigma \underline{m}=17, \log _{2} M=\log _{2} 17=4.085, A=0.1891+$ $0.4085=0.5976$ (Table 5.8).

From the data given in Table 5.7 it can be seen that the populus balsamifera, ulmus pumila, acer negundo and malus baccata. ta are mainly recommended for removal (cutting down). Factors of destabilisation of the state and disruption of useful functions of green plantations of the city of Astana are natural and anthropogenic factors. The natural factors are that the city is territorially located in the steppe zone, in the subzone of dry fescue-feather grass steppes with sharply continental climate, characterised by a significant moisture deficit, severe low-snow and prolonged winters, strong winds and abrupt temperature changes within $24 \mathrm{~h} \mathrm{[150].}$

Table 5.9.

Values of diversity indices of plants on the territory of the Ijevan subtropical arboretum.

\begin{tabular}{|l|c|c|c|c|c|c|c|}
\hline Name of the plant & H & D & D-1 & 1/D & G & A & K \\
\hline Cedrus deodara & 1.3 & 0.4164 & 0.5838 & 2.403 & 0.2586 & 0.4906 & 1.5 \\
\hline Cédrus atlántica) & 0.91 & 0.5480 & 0.4519 & 1.8247 & 0.1823 & 0.2823 & 1.33 \\
\hline $\begin{array}{l}\text { Cryptomeria } \\
\text { japonica) }\end{array}$ & 1.52 & 0.333 & 0.666 & 3 & 0.4875 & 0.7195 & 1.8 \\
\hline Cupressus arizonica & 1.92 & 0.25 & 0.75 & 4 & 0.7063 & 0.9383 & 2.6 \\
\hline $\begin{array}{l}\text { Acer } \\
\text { pseudoplatanus }\end{array}$ & 1.92 & 0.265 & 0.735 & 3.773 & 0.5163 & 0.9483 & 2.0 \\
\hline Populus pyramidalis & 1.91 & 0.263 & 0.263 & 3.8052 & 0.5598 & 0.7918 & 2.1 \\
\hline Pinus pallasiana & 1.8 & 0.275 & 0.725 & 3.636 & 0.8170 & 0.9170 & 1.93 \\
\hline Pinus Weiwutow & 0.6868 & 0.6883 & 0.3118 & 1.4528 & 0.1821 & 0.3405 & 1.18 \\
\hline Malus & 1.567 & 0.3979 & 0.6021 & 2.513 & 0.2647 & 0.6967 & 1.5 \\
\hline
\end{tabular}


Anthropogenic factors that adversely affect the green plantings of the city of Astana include the following: dustiness and gassing of the atmosphere, high density of communal structures, etc. One of the main reasons is salinization of soils. For plantings it is necessary to carry out preventive measures for their care, consisting in the following: application of mineral fertilisers, pruning of shrinking branches.

Assessment of the values of plant diversity indices in the territory of Ijevan subtropical arboretum is demonstrated in Table 5.9.

From the values of the indices of diversity for plants on the territory of the Ijevan Dendrological Park, it can be seen that A, G. $\mathrm{H}$ and $\mathrm{K}$ have high values for Cryptomeria japonica, Cupressus arizonica, Acer pseudoplatanus, Populus pyramidalis and Pinus pallasiana indicating that they are in a bad state.

Further, a correlation matrix was computed, using all the indices values, in order to establish the indices relationships and similar behaviours (Table 5.10).

Table 5.10.

Correlations between diversity indices.

\begin{tabular}{|l|c|c|c|c|c|}
\hline & H & D & K & G & A \\
\hline H & 1 & -0.97379 & 0.85474 & 0.80741 & 0.8588 \\
\hline D & -0.97379 & 1 & -0.80741 & -0.77274 & -0.82176 \\
\hline K & 0.85474 & -0.80741 & 1 & 0.79766 & 0.6655 \\
\hline G & 0.80741 & -0.77274 & 0.79766 & 1 & 0.65936 \\
\hline A & 0.8588 & -0.82176 & 0.6655 & 0.65936 & 1 \\
\hline
\end{tabular}

Analysis of obtained data indicates that $\mathrm{A}$ has liner dependence on $\mathrm{H}, \mathrm{G}, \mathrm{K}$, and an inverse dependence on D. The correlation coefficients have large values, as expected, indicating strong associations between diversity indices and 
statistically all the relationships can be designated as highly significant.

Thus, studies have shown that the current state of green plantations on the territory of the KAU does not meet the current standards and requirements. The existing level of gardening of the investigated object is uneven.

It is shown that for the plants in the Ijevan subtropical arboretum the values of diversity indices: A, G. H and K have high values for the Cryptomeria japonica, Cupressus arizonica, Acer pseudoplatanus, Populus pyramidalis and Pinus pallasiana, indicating that they are in poor condition.

It is established, that the Armenian index of environmental quality has liner dependence on Shannon diversity and EWQI indices, weighted average category of plants, and an inverse dependence on the Simpson diversity indices. The correlation coefficients have large values, as expected, indicating strong associations between diversity indices and statistically all the relationships can be designated as highly significant [144].

\subsection{Assessment of the maturity of oil and natural gas pools by means of the Entropy Index}

Oil belongs to the group of rocks along with sands, clays, limestone, rock salt, etc. It has one important property - the ability to burn and release thermal energy. Among other combustible minerals, it has the highest calorific value. For example, for heating a boiler room or other installation, oil is required that is significantly less in weight than coal. All combustible rocks belong to a special family, called 
caustobioliths (from the Greek words "caustos" - combustible, "bios" - life, "lithos" - stone, that is, combustible organic stone) [151-158].

Oil is formed in the interior of the Earth from deep mantle fluids and is a renewable resource. Oil is a mutual solution of the closest homologues and other compounds in each other. More than a thousand of individual organic substances were found in the composition of oil, containing: carbon, hydrogen, oxygen, nitrogen, sulfur, and more than 60 elements.

The carbon content in oils varies between $80-87 \%$, and hydrogen in oils $10-14.5 \%$. Among the other elements in oils, sulfur, oxygen and nitrogen are most common. The maximum content of these elements can reach up to $5-8 \%$ in total. The sulfur content in individual oils reaches 6-8\%. The oxygen content in oils sometimes reaches $1-2 \%$, and nitrogen in oils does not exceed $1 \%$.

A simple mathematical calculation shows that the ratio of the five main elements in oil corresponds on average to the chemical formula [152]

$$
\begin{gathered}
\ll \mathbf{C H}_{\mathbf{1}, \mathbf{7 6}} \mathbf{S}_{\mathbf{0 . 0 1 8}} \mathbf{O}_{\mathbf{0 . 0 0 9}} \mathbf{N}_{\mathbf{0 . 0 0 6}} »: \\
\mathrm{C}: \mathrm{H}: \mathrm{S}: \mathrm{O}: \mathrm{N}=\frac{(80+87)}{(2 \times 12)}: \frac{(10.0+14.5)}{(2 \times 1)}: \frac{(0.03+8)}{(2 \times 32)}: \frac{(0.02+2)}{(2 \times 16)} \\
: \frac{(0.03+1)}{(2 \times 14)}= \\
6.96: 12.25: 0.125: 0.063: 0.041=1: 1.76: 0.018: 0.009: \\
0.006
\end{gathered}
$$

The following parts are distinguished in oils: hydrocarbon, asphalt-resinous, porphyrins, sulfur and ash. Each oil has a 
dissolved gas that is released when it reaches the earth's surface. The composition of the oil includes hydrocarbon and heteroorganic chemical compounds.

The main part of the oil is hydrocarbons, different in their composition, structure and properties, which can be in the gaseous, liquid and solid state. The composition of the oil includes more than four hundred hydrocarbon compounds. Depending on the structure of the molecules, they are divided into three classes - paraffinic, naphthenic and aromatic. But a significant part of oil is made up of mixed hydrocarbons containing the structural elements of all three mentioned classes. By the quantitative ratio of various groups of hydrocarbons contained in oil, all oils are grouped into four classes:

1) methane containing more than $66 \%$ methane hydrocarbons;

2) naphthenic containing more than $66 \%$ naphthenic hydrocarbons;

3) naphthene-methane, in which the content of methane and naphthenic hydrocarbons in the amount of more than 66\%;

4) all oils of "unusual composition", i.e. aromatic and others

According to the paraffin content of oil they are divided into three groups:

1) non-paraffin-paraffin to $1 \%$;

2) low paraffin - paraffin 1-2\%;

3) paraffin - paraffin over $2 \%$.

According to the sulfur content of oil they are divided into two groups:

1) low-sulfur - sulfur to $0.5 \%$;

2) high-sulfur - sulfur more than $0.5 \%$. 
According to the content of asphaltenes and resins, three groups of oils are distinguished:

1) light resin - resins less than $8 \%$;

2) resinous - resin $8-28 \%$;

3) strongly resinous - resins more than $28 \%$.

More than 60 microelements has founded in the composition of oil, half of them are metals. The average concentrations of trace elements in oils decrease in the following row: $\mathrm{Cl}, \mathrm{V}, \mathrm{Fe}, \mathrm{Ca}, \mathrm{Ni}, \mathrm{Na}, \mathrm{K}, \mathrm{Mg}, \mathrm{Si}, \mathrm{Al}, \mathrm{I}, \mathrm{Br}, \mathrm{Hg}, \mathrm{Zn}, \mathrm{P}, \mathrm{Mo}$, $\mathrm{Cr}, \mathrm{Sr}, \mathrm{Cu}, \mathrm{Rb}, \mathrm{Co}, \mathrm{Mn}, \mathrm{Ba}, \mathrm{Se}, \mathrm{As}, \mathrm{Ga}, \mathrm{Cs}, \mathrm{Ge}, \mathrm{Ag}, \mathrm{Sb}, \mathrm{U}, \mathrm{Hf}$, $\mathrm{Eu}, \mathrm{Re}, \mathrm{La}, \mathrm{Sc}, \mathrm{Pb}, \mathrm{Au}, \mathrm{Be}, \mathrm{Ti}, \mathrm{Sn}$.

In natural oils and solid bitumens, metals are in the following forms: $\mathrm{Cu}, \mathrm{Fe}, \mathrm{Pb}$ and $\mathrm{U}$ form true solutions; $\mathrm{Zn}, \mathrm{Cu}$, $\mathrm{Ni}, \mathrm{U}, \mathrm{Ca}, \mathrm{Mg}, \mathrm{Fe}$ and $\mathrm{V}$ form colloidal solutions adsorbed on the active surface oil / water; $\mathrm{Cu}, \mathrm{Zn}, \mathrm{Ge}, \mathrm{Au}$ are found in polar resins in the form of salts of organic acids; $\mathrm{Hg}, \mathrm{Sb}, \mathrm{As}, \mathrm{V}, \mathrm{Ni}$, $\mathrm{Fe}, \mathrm{Cu}, \mathrm{Co}, \mathrm{Cr}$ form organometallic compounds, and $\mathrm{V}$ and $\mathrm{Ni}$ form metal porphyrin complexes. It has been established that the concentration of most trace elements increases with increasing molecular weight and aromaticity of asphaltenes, and asphaltene fractions enriched with microelements always have an increased content of nitrogen, sulfur and oxygen [159-165].

It is assumed that metal atoms create complex compounds with asphaltene heteroatoms in a donor-acceptor type.

On the gold ore manifestation of the Pioneer Degdekan ore field of Central Kolyma, in the zone of sedimentary bituminization, an increase in the concentration of gold by an order of magnitude and more is observed compared with the clarke content. Gold content in bitumen averaged $520 \mathrm{~g} / \mathrm{t}$, which 
significantly exceeds the content of this metal in many of its primary deposits. The fact that gold and naphthides coexist is shown at the Witwatersrand gold deposits in South Africa and Muruntau in Uzbekistan. Manifestations of gold in the amount of $0.438 \mathrm{mg} / \mathrm{t}$ are found in the oils of Mexico and Alberta in Canada. The association of gold and other metals with hydrocarbons and organic matter is caused by their ability to form organometallic compounds of various types. Gold in the amount of up to $2 \mathrm{~g} / \mathrm{t}$ for one of the fractions was found in hydrothermal bitumens in the ancient volcanic pipes of Siberia.

Petroleum also contains other metals- $\mathrm{Mo}, \mathrm{Pb}, \mathrm{Ag}, \mathrm{Zn}, \mathrm{Cr}$ and so on.

Molybdenum in oils is contained in the amount of several $\mathrm{g} / \mathrm{t}$. For example, the molybdenum content in solid bitumens and heavy oils of Athabasca, Cold Lake and Lloydminster is 10, 7.3 and $3.3 \mathrm{~g} / \mathrm{t}$, respectively. The average molybdenum content in Venezuelan oil is $60 \mathrm{~g} / \mathrm{t}$.

Tin was found in less than half of the oil in the western United States. Silver is present in the ash residues of oil in the western US less than $1 \mathrm{~g} / \mathrm{t}$. The average content in Alberty oils of cesium, rubidium and europium is 4.3, 0.015 and $0.94 \mathrm{~g} / \mathrm{t}$, respectively. In a number of oil-bearing regions, Cheleken and Gulf-Coast, plugs from native lead and zinc or their sulfides are formed in wells drilled in oil.

Vanadium and nickel deserve special attention, their concentrations in oils are much higher than in living matter. Vanadium and nickel are among the first metals found in oil. After burning the oil, a ash residue remains, which is rich in metals. due to their elevated concentrations in comparison with 
other metals. The concentrations of these metals in the oil of individual deposits are so significant that they are quite comparable with the metal content in the ores, the extraction of which is quite profitable. The maximum content of vanadium in oil is $6 \mathrm{~kg} / \mathrm{t}$. In the oil in the Officein retinue within the East Venezuelan basin, the average vanadium content is $335 \mathrm{~g} / \mathrm{t}$. In the Devonian oil of Alberta in Canada, vanadium contains an average of $13.6 \mathrm{~g} / \mathrm{t}$. In the oil of Illinois, vanadium is $0.35 \div 1.5$ $\mathrm{g} / \mathrm{t}$, and in Arabic $-9.52 \div 51 \mathrm{~g} / \mathrm{t}$. The ash residue from the deposits in the western United States contains 5-50\% vanadium. Vanadium is present in almost all oil fields in Western Kazakhstan. Akbulak oil contains vanadium up to $400 \mathrm{~g} / \mathrm{t}$, and Buzachinsk oil contains up to $300 \mathrm{~g} / \mathrm{t}$. Within the Ural ore belt, oil contains up to $569 \mathrm{~g} / \mathrm{t}$ vanadium, and solid bitumens contain vanadium up to $1230 \mathrm{~g} / \mathrm{t}$.

In natural oils, metal etioporphyrins and metal deoxyophylloerythroethioporphyrins containing an isocyclic ring and with $\mathrm{Ni}^{2+}$ and $-\mathrm{VO}^{2+}$ in the center of the porphinic core predominate. Metal porphyrin complexes are present in natural bitumens in an amount up to $1 \mathrm{mg} / 100 \mathrm{~g}$, and in high-viscosity oils - up to $20 \mathrm{mg} / 100 \mathrm{~g}$ of oil; It was found that $40 \%$ of vanadilporphyrins are concentrated in dispersed particles, and the rest of them (and nickel-porphyrins, too) are contained in a dispersed medium. By the way, both types of metalloporphyrins in the composition of asphaltenes make a significant contribution to the surface activity of oils. In sulfur oils, more porphyrins are present in the form of the vanadium complex, and in low-sulfur, and especially nitrogen-rich oils, nickel complexes predominate. Their concentrations are of the same 
order. About $5-10 \%$ of oil porphyrins are more condensed with respect to alkyl porphyrins.

These compounds are attributed to the structure of bicycloalkanoporphyrins, benzoporphyrins, cycloalkanomonobenzoporphyrins.

"Naphthids" - hydrocarbons in gas, liquid, semi-solid and solid states or as a mixture of these phases. The mantle fluids along deep faults move and penetrate into the Earth's crust, where they form naphtide systems. According to D.N. Timofeev potential reserves of hydrocarbons on our planet is $1.9 \times 10^{18}$ tons. Naphthides are unstable open fluid-dynamic systems that, under the influence of man-made, deep-earth, surface, cosmic processes, can self-organize in the direction of chaos, of which entropy is a measure, or in the direction of order. In open horodinamic systems, which include naphthid ones, processes can proceed both with restoration, and with a decrease in entropy.

The purpose of this work is to evaluate the state of naphthide systems using the chemical component composition of naphthid systems using an entropy index.

In accordance with the purpose of the work and the formulation of the problem, the entropy index of natural gas, associated gas from oil fields and oil fractions were calculated. Tables 5.11-5.13 show the corresponding entropy index calculations. 
Table 5.11.

Chemical composition (vol.\%) and values I, H, G of natural gas.

\begin{tabular}{|c|c|c|}
\hline Natural gas composition & $\mathbf{n}$ & $\mathbf{n l o g}_{2} \mathbf{n}$ \\
\hline $\mathrm{CH}_{4}$ & 94 & 615.8 \\
\hline $\mathrm{C}_{2} \mathrm{H}_{6}$ & 3 & 4.75 \\
\hline $\mathrm{C}_{3} \mathrm{H}_{8}$ & 0.4 & 0 \\
\hline $\mathrm{N}_{2}$ & 2 & 2 \\
\hline $\mathrm{CO}_{2}$ & 0.6 & 0 \\
\hline $\mathbf{N}$ & \multicolumn{2}{|c|}{622.55} \\
\hline$\sum n \log _{2} n$ & \multicolumn{2}{|c|}{6.23} \\
\hline $\mathrm{I}$ & \multicolumn{2}{|c}{0.41} \\
\hline $\mathrm{H}$ & \multicolumn{2}{|c}{0.066} \\
\hline $\mathrm{G}$ & \multicolumn{2}{|c}{} \\
\hline
\end{tabular}

Table 5.12.

Chemical composition (vol.\%) and values of I, H, G of oil fields (associated gas).

\begin{tabular}{|c|c|c|c|c|c|c|c|c|c|c|}
\hline Field & $\mathbf{C H}_{\mathbf{4}}$ & $\mathbf{C}_{\mathbf{2}} \mathbf{H}_{\mathbf{6}}$ & $\mathbf{C}_{\mathbf{3}} \mathbf{H}_{\mathbf{8}}$ & $\mathbf{C}_{\mathbf{4}} \mathbf{H}_{\mathbf{1 0}}$ & $\mathbf{C}_{\mathbf{5}} \mathbf{H}_{\mathbf{1 2}}$ & $\mathbf{N}_{\mathbf{2}}$ & $\mathbf{C O}_{\mathbf{2}}$ & $\mathbf{I}$ & $\mathbf{H}$ & $\mathbf{G}$ \\
\hline $\begin{array}{c}\text { Bavlinskoe } \\
\text { Romashkins } \\
\text { koye }\end{array}$ & 35,0 & 20,7 & 19,9 & 9,8 & 5,8 & 8,4 & 0,4 & 4.28 & 2.36 & 0.55 \\
\hline Samotlor & 53,4 & 7,1 & 17,8 & 8,0 & 6,8 & 8,0 & 1,5 & 4.28 & 2.36 & 0.55 \\
\hline Uzen & 50,2 & 20,2 & 16,8 & 7,7 & 3,0 & 2,3 & - & 4.69 & 1.95 & 0.42 \\
\hline
\end{tabular}

Table 5.13.

Values of I, H, G for fractions of a number of oils.

\begin{tabular}{|c|c|c|c|}
\hline Oil fraction & I & H & G \\
\hline The first fraction of Kumkol oil & 3.85 & 2.79 & 0.72 \\
\hline The second fraction of Kumkol oil & 3.45 & 3.19 & 0.91 \\
\hline Gasoline fraction Karazhanbas oil & 3.18 & 3.46 & 1.09 \\
\hline Kerosene oil fraction Karazhanbas & 3.28 & 3.36 & 1.02 \\
\hline
\end{tabular}


- In the series natural gas $\rightarrow$ associated gas $\rightarrow$ oil, entropy increases, and geo-ecological syntropy decreases. It is curious that for natural gas $\mathrm{G}=0.066$, which indicates a high degree of freedom of the gas phase [166-168].

- For oil, the entropy index tends to unity, which indicates that when oil is formed in the trap mainly from the mantle highenergy fluid, the structural organization of the oil reservoir is equilibrium.

- Along with other geo-information methods and technologies, it is recommended to use the entropy index to estimate the maturity of oil deposits.

\subsection{Surface water pollution by vanadium}

Detection of oil mines is closely related to reliability and accuracy of geochemical search. The economic efficiency of oil extraction is depending on the quality and efficiency of mine exploration, as the exploration probe is worth millions of dollars. Therefore, the development of a rapid and accurate method of detecting oilfield is effective and actual. Many geochemical methods of detecting deposits are known. For example,biogeological (briogeochemical, phytogeochemical, geobiological), hydrogeochemical, geochemical and gasogeochemical[169]. The method for detecting oil fields differs from the sampling surface of the water surface and compares the obtained data with the vanadium permissible concentration and judges the location of the oilfield with a 10fold exceedance of the vanadium permissible concentration 
According to the suggested method surface water are sampled, the concentration of vanadium in samples are determined by atom-absorption spectroscopy, analyzes the data are obtained and confirmed the location of the oil field.

Example. Water sampling was carried out by the Ministry of Nature Protection of the Republic of Armenia, in the monitoring stations approved by the Environmental Impact Monitoring SNCO and their adjacent water areas (by their regular number plates) each month during 2007-2014. The selected data is presented in Table 5.14 below. The table contain only those points where the content of vanadium has been exceeded by at least 10 times, due to the presence of oil mines.

Oil fields in the territory of the Republic of Armenia were found at the territory of Yeghvard-Byureghavan-Ashtarak settlements[170], which are lied between the Hrazdan and Kasakh rivers. In the water taken from the Kasakh River \# 45 (1 $\mathrm{km}$ above Ashtarak), 10.6 concentration of $\mathrm{V}$ were detected and $12.2 \mathrm{~V}$ content was detected in the water taken from the Hrazdan River No. 54.

Table 5.14.

Water quality class, hydrochemical parameters and pressure-impact analysis of the rivers in Armenia in 2007-2014.

\begin{tabular}{|c|c|c|c|}
\hline \multirow{2}{*}{ River } & $\begin{array}{c}\text { Sampling } \\
\text { points }\end{array}$ & Observation point & $\begin{array}{c}\text { Over } \\
\text { average }\end{array}$ \\
\hline \multirow{4}{*}{ Araks } & 25 & Near Surmalu village & 16 \\
\cline { 2 - 4 } & 26 & $\begin{array}{c}\text { Upstream Hrazdan } \\
\text { river intake }\end{array}$ & 11.6 \\
\cline { 2 - 4 } & 27 & $\begin{array}{c}\text { Downdtream } \\
\text { Hrazdan river intake }\end{array}$ & 12.6 \\
\hline
\end{tabular}




\begin{tabular}{|c|c|c|c|}
\hline River & $\begin{array}{l}\text { Sampling } \\
\text { points }\end{array}$ & Observation point & $\begin{array}{c}\text { Over } \\
\text { average }\end{array}$ \\
\hline & 28 & $\begin{array}{c}0.5 \mathrm{~km} \text { downstream } \\
\text { Armash village }\end{array}$ & 10.8 \\
\hline & 29 & $\begin{array}{c}2 \mathrm{~km} \text { south Agarak } \\
\text { town }\end{array}$ & 11.8 \\
\hline & 30 & $\begin{array}{l}2.5 \mathrm{~km} \text { south-east } \\
\text { Agarak town }\end{array}$ & 11.2 \\
\hline \multirow{2}{*}{ Akhuryan } & 33 & $\begin{array}{l}0.8 \mathrm{~km} \text { upstream } \\
\text { Gyumri town }\end{array}$ & 12.75 \\
\hline & 34 & $\begin{array}{l}\text { 5km downstream } \\
\text { Gyumri town }\end{array}$ & 11.75 \\
\hline \multirow{3}{*}{ Sevdjur } & 40 & $\begin{array}{c}\text { 10km south of } \\
\text { Vagharshapat town }\end{array}$ & 18.7 \\
\hline & 41 & $\begin{array}{l}11 \mathrm{~km} \text { south-east of } \\
\text { Vagharshapat town }\end{array}$ & 16.8 \\
\hline & 42 & $\begin{array}{l}\text { 0.5km downstream } \\
\text { Ranchpar village }\end{array}$ & 13.8 \\
\hline \multirow{3}{*}{ Kasakh } & 45 & $\begin{array}{l}1 \mathrm{~km} \text { upstream } \\
\text { Ashtarak town }\end{array}$ & 10.6 \\
\hline & 46 & $\begin{array}{c}3.5 \mathrm{~km} \text { downstream } \\
\text { Ashtarak town }\end{array}$ & 10.8 \\
\hline & 47 & near River mouth & 11.1 \\
\hline \multirow{4}{*}{ Hrazdan } & 53 & $\begin{array}{c}0.5 \mathrm{~km} \text { downstream } \\
\text { Argel village }\end{array}$ & 11.8 \\
\hline & 54 & $\begin{array}{c}0.5 \mathrm{~km} \text { downstream } \\
\text { Arzni HPP } \\
\end{array}$ & 12.2 \\
\hline & 55 & $\begin{array}{c}\text { 6km downstream } \\
\text { Yerevan city, near } \\
\text { Darbnik village }\end{array}$ & 15.8 \\
\hline & 56 & near River mouth & 14.2 \\
\hline Masrik & 63 & near River mouth & 13.2 \\
\hline Karchaghbyur & 67 & near River mouth & 10.2 \\
\hline Gavaraget & 78 & near River mouth & 20 \\
\hline Arpa & 85 & $\begin{array}{l}\text { 0.5km downstream } \\
\text { Vaykh town }\end{array}$ & 10.6 \\
\hline
\end{tabular}




\begin{tabular}{|c|c|c|c|}
\hline \multirow{2}{*}{ River } & $\begin{array}{c}\text { Sampling } \\
\text { points }\end{array}$ & Observation point & $\begin{array}{c}\text { Over } \\
\text { average }\end{array}$ \\
\hline \multirow{3}{*}{ Vorotan } & 100 & $\begin{array}{c}1 \mathrm{~km} \text { upstream Sisian } \\
\text { town }\end{array}$ & 25.6 \\
\cline { 2 - 4 } & 101 & $\begin{array}{c}\text { 2km downstream } \\
\text { Sisian town }\end{array}$ & 25.3 \\
\hline \multirow{2}{*}{ Gorisget } & 106 & $\begin{array}{c}3 \text { km upstream Goris } \\
\text { town }\end{array}$ & 13.1 \\
\cline { 2 - 4 } & 107 & $\begin{array}{c}1.5 \text { km downstream } \\
\text { Goris town }\end{array}$ & 19.8 \\
\hline
\end{tabular}

Artashat-Masis-Arax River (Artashatian Descent), where it was also discovered oil in the Hrazdan-Sevjur-Araks rivers[170], on the Sevjur River \# 40 (10 km from south of Vagharshapat), \# 41 (11 km south-east of Vagharshapat), the content of V in watermelons \# 42 (0.5 km from Ranchpar) was higher than the TM content by 18 times, respectively, 16.8 times, 13.8 times, V content in the Araks River No. 26, exceeded the TM 11.6 times and the Hrazdan River The content of $\mathrm{V}$ in the water from the observation point No 55 (near Darbnik) exceeded the TMC 15.8 times. In Table 5.14, all points of observation are considered to be oil prospective quarries[171].

Based on the foregoing, application of the following invention will enable the determination of the presence of oil mines in the riverbed area, especially in difficult-to-reach mountainous areas. The proposed weather is reliable and costly, unlike the current geological prospecting methods. 


\section{References}

1. Alekin A., Hydrochemistry: Sankt-Petersburg, Hydrometeorological publishing of Leningrad, 1970, 444p. (in Russian)

2. Askhabov A.M. Nanocluster model of liquid water formation. Izvestiya Komi Scientific Center UB RAS, 2016, No.1 (25), 62-67pp.

3. Bloch A. M. The structure of water and geological processes. M., Nedra, 1969, 216p. (in Russian)

4. Adamyan R.Kh. Inorganic chemistry (in two volumes). Volume 1, Book 1 Chemistry of intransitive elements.Yerevan: YSU, 2018, 382p. (in Armenian)

5. Mosin O.V, Ignatov I. The structure of water. Chemistry. 2013. No.1, 12-32pp. (in Russian)

6. Nikanorov A.M., Hydrochemistry. - SPb: Gidrometeoizdat, 2001, 444p. (in Russian)

7. Letnikov F.A., Kashcheeva T.V., Mincis A.Sh. Activated water. Novosibirsk, Science, 1976, 135p. (in Russian)

8. Simonyan G.S., Harutyunyan N.M., The concept of abnormal and specific properties of water. Science and education today, 2018, No 4(27), 13-15pp. (in Russian)

9. Rivkin S.L., Aleksandrov A.A. Thermophysical properties of water and water vapor. -M., Energy, 1980, 424p. (in Russian)

10. Directive 2000/60/EC of the European Parlament and of the Council of 23 October 2000 establishing a frameworc for Community action in the field of water policy. 
11. ENPI / 2011 / 281-959 Technical Report "Analysis of Current Water Quality Assessment Systems in Armenia, Georgia and Azerbaijan in the Context of WFD Requirements", EU "Transboundary Rivers III Phase - Kur River - Armenia, Georgia and Azerbaijan", 2012

12. Fomin G.S., Water, Control of chemical, bacterial and radiation safety to international standards. Moscow, 2000, 370p. (in Russian)

13. Shahnazaryan G.A., Minasyan S.H., Pirumyan G.P., Integrated Water Pollution Assessment of the Araks River by the Hydrochlorical Results of 2005. Information Technologies and Management, Yerevan, 2006, No. 4-2, 69-87pp. (in Armenian)

14. Shahnazaryan G.A., Pirumyan G.P., Minasyan S.H., Comprehensive evaluation of Debed River water quality by index methods. Information Technologies and Management, Yerevan, 2008, No 5, 40-52pp. (in Armenian)

15. Shahnazaryan G.A., Pirumyan G.P., Seasonal variability of nutrient content of the Agstev River. First Scientific Conference of the Armenian Chemical Society Actual Problems of the Chemical Science of Armenia, Abstracts of Reports, July 2008, Yerevan, 65p. (in Russian)

16. Shitikov V., Rosenberg G., Zinchenko T. Quantitative hydroecology: methods, criteria, solutions: in 2 books. $-\mathrm{M}$., Science, - 2005. -Kn. 1.- 281p. (in Russian)

17. Observation stations of water quality and quantity in Armenia, Agency of Hydrometeorology and Environmental Impact Monitoring, Ministry of Nature Protection of the Republic of Armenia, Yerevan, 2003, 20p. 
18. Dictionary of Physical-Geographic Objects in the Republic of Armenia. State Committee of the Real Estate Cadastre.Yerevan, Armenia, 2007. 136p. (in Armenian)

19. Hydrological Year books, Annual report books of Hydrometeorology and Monitoring State Service of Armenia, 1969-2013. www.meteo.am

20. Tutunjan A.A., Pirumyan G.P., Ecological-hydrochemical assessment of ground and surface waters. IV international scientific conference "Water resources, ecology and hydrological safety", Moscow, 2010, 179-181pp. (in Russian)

21. Margaryan L.A. Assessment of the impact of climate change on the quality and quantity of drinking water sources in Armenia. Ecological chemistry. St. Petersburg, vol.26 (issue 2), 2017, 71-78p. (in Russian)

22. Margaryan L.A. Impact of mining enterprises on the quality of water in rivers. Chemical safety Moscow, Vol. 1 No. 1, 2017, 86-91p. (in Russian)

23. Margaryan L.A. Impact of domestic wastewater on surface water quality in some residential settlements of Armenia. European Water. Vol. 53, 2016, 5-12p.

24. Margaryan L.A. Assessment of the Climate Change Impact on the Quality and Quantity of Drinking Water Sources in Armenia. Russian Journal of General Chemistry, v.87, №13, 2017, 3014-3020pp.

25. BMU (Federal Ministey for the Environment, Nature Conversation and Nuclear Safety): Environmental Policy, Water Resource Management in Germany, Part 2-Water Quality 2006, 33-88p. 
26. Biryukova M. G., Yurchenko V.V., Karapun M.Y., Znobishchev A. A., Comparative Characteristics of The Volga-Akhtuba Watershed Hydrobiocenoses According to Indicators of Biodiversity and Saprobity. Vestnik of Astrakhan State Technical University, Series: Fishing Industry, 2017, v. 2, 26p. (in Russian)

27. Le Nouveau Sisteme d`evaluation de la qualite de l'eau des rivers: Le SEG-eau Adour- Garone, Revue de l’eue, Hiver, 2001, № 81, 7-9p.

28. Pirumyan G., Pirumyan E., Simonyan G., Simonyan A., Method of Determining the Level of Water Pollution. RA Patent, 2016, No 3063A.

29. Surmalyan V., Minasyan S., Pirumyan G., Assessment of pollution levels of Gavaraget and Dzaghnaget and their impact on Small Sevan based on hydrochemical data. Information Technologies and Management, Yerevan, 2008, No 2, 93-102pp. (in Armenian)

30. Surmalyan V., Minasyan S., Pirumyan G., Assessment of Drakhtik river water quality based on hydrochemical data. The importance of ecology and nature protection in the perspective of sustainable development. International Conference Materials. Yerevan, 2008, No 44pp. (in Armenian)

31. Surmalyan V., Minasyan S., Pirumyan G., Assessment of Drakhtik river water quality based on hydrochemical data. Information Technologies and Management, Yerevan, 2008, No 8, 132-139pp. (in Armenian)

32. Surmalyan V., Pirumyan G., Hydrochemical assessment of water pollution level in Gavaraget, Dzknaget and Drakhtik 
rivers. Water abnd Ecology: problem and solutions, Sankt Petersburg, 2009, No 3, 62-67pp. (in Russian)

33. Surmalyan V., Minasyan S., Pirumyan G., Assessment of Shoghvak, Tsakkar, Lichk rivers water quality based on hydrochemical data. Information Technologies and Management, Yerevan, 2009, No 7, 204-213pp. (in Armenian)

34. Surmalyan V., Minasyan S., Pirumyan G., Assessment of Argitchi river water quality based on hydrochemical data. Information Technologies and Management, Yerevan, 2009, No 7, 213-221pp. (in Armenian)

35. Surmalyan V., Minasyan S., Pirumyan G., Gavaraget, Dzknaget, Draxtik, Argichi, Shoghvak, Tsakkar, Lichk Rivers' water quality assessment with dates of hydrochemical. "Technology-2011" XIV National Scientific Conference materials, East Ukraine Volodymyr Dahl National University (STI), part 1, Severodonetsk, April 2011, 133p.

36. Surmalyan V., Minasyan S., Pirumyan G., Climate change impact on the Gavaraget, Dzknaget, Draxtik, Argichi, Shoghvak, Tsakkar, Lichq Rivers' water quality in RA. Advances in Mass Spectrometry for petrochemistry, Environmental and food chemistry -2011. XIV National Scientific Conference materials, TIPS RAS, part 1, Moscow, November 2011, 162p.

37. The RA Government Decree N75-N of 27 March 2011 "On the Establishment of Water Quality Standards for Each Water Basin Management Area Depending on the Territory Peculiarities" (in Armenian) 
38. Vardumyan L.E., Minasyan S.H., Piroumyan G.P., Complex analysis of water quality of Goris river with different index methods. International Conference "The Importance of Ecology and Nature Protection in the Stable Development Perspective". International Conference Materials, Yerevan, November 2008, 46p. (in Armenian)

39. Vardumyan L.E., Piroumyan G.P., Minasyan S.H., Complex analysis of water quality of Goris River on the basis of hydrochemical data. Armenian Engineering Academy Newsletter, 2009, no. 6 (3), 461-465pp. (in Armenian)

40. Vardumyan L.E., Vardumyan E.E., Piroumyan G.P., Minasyan S.H, Evaluation of the water quality of the rivers of the Southern River Basin of Armenia by the main component analysis method. Armenian Engineering Academy Newsletter, 2011, no. 8 (1), 196-202pp. (in Armenian)

41. Water quality in the Danube River Basin-2004, Yerbook. International Comunicions for the Danube River, 2005

42. Chilingaryan, L.A.; Mnatsakanyan, B .P.; Aghababyan, K.A.; Tokmajyan, H.V. Watercourse of Armenian rivers and lakes, Agropress, Yerevan, Armenia, 2002, 50 p. (in Armenian)

43. CCIC Report, Vulnerability of Water resources in the Republic of Armenia Under Climate change, Yerevan, Climate Change Information Center, Ministry of Nature Protection of RA, 2009, 26p. 
44. Simonyan A. G., Pirumyan G. P., Simonyan G.S., Analysis of Environmental Status of the Kechut Artificial Reservoir and River Arpa with Armenian Index of Water Quality. Austrian Journal of Technical and Natural Sciences, 2016, v.7-8, 37p.

45. Horton R.K. An index number system for rating water quality. Journal on Water Pollution Control Fed, 1965. v.37(3), 300p.

46. Brown R.M., Mclennald N.I., Deininger R.A., Tozer R.G. A water quality index: Do we are? Water and Sewage works. 1970, v.117(10), 339-343pp.

47. Kumar D., Alappat B. NSF-Water quality index: Does it represent the experts' opinion? Pract. Period. Hazard. Toxic Radioact. Waste manage., 2009, v.13(1), 75-79pp.

48. CCME Water Quality Index. Technical Report. Excerpt from Public. Ni 1299, 2001, ISBN 1-896997-341,Winnipeg.

49. Islam N., Sadiq R., Robriguez M.J., Optimizing booster chlorination in water distribution networks: a water quality index approach. Environ. Monit. Assess., 2013, v.185 (10), 8045-8050pp.

50. Cude C.G., Oregon Water Quality Index: A tool for Evaluating Water Quality Management Effectiveness. J. of the American Water Resources Association, 2001, v. 37(1), 125-137pp.

51. Dunnette D.A. A geographically variable water quality index used in Oregon. Journal on Water Pollution Control fed, 1979.v. 51(1), 53-61pp. 
52. Zulkifli A.R. Water quality management in Malaysia. Department of Environment Malaysia, 2000, 35p.

53. Department of Environment Malaysia (DOE) 2013 Malaysia Environmental Quality Report on 2012 (Report No. WEQR-2012). Putrajaya. OMR press Sdn.Bhd.

54. Dinius S.H. Design of an index of water quality. Journal of the American Water resources Associatior., 1987. V.23 (5), 833-843pp.

55. Ott.W. Water quality indices: A survey of indices used in the United States. Environmental Protection Agency, Office of Research and Development, Office of Monitoring and Technical support, 1978, v.1, 154p.

56. Poonam T., Tanushree B., Sukalyan C. Water quality indices - important tools for water quality assessment: a review. International Journal of Advances in Chemistry, 2013, v.1 (1), 15-28pp.

57. Bascaron M. Establishment of a methodology for the determination of water quality. Boltein Informativo del Medio Ambiente, 1979, v.9, 30-51pp.

58. Debels P., Figueroa R., Urrutia R., Barra R., Nielle X. Valuation of water quality in the Chilla'n River (Central Chile) using physicochemichal parameters and a modified water quality index. Environ. Monit. Assess. 2005, v.110, 301-322pp.

59. Sargaonkar A., Veshoande V. Development of an overall index of pollution for surface water based on a general classification scheme in Indian context. Environ. Monitoring Assess., 2003, v.89, 43-67pp. 
60. Nagels J.W., Colley D., Smith D.G., A water quality index for contact recreation in New Zealand. Water Sci. technol., 2001, v.43(5), 285-292pp.

61. SRDD, Scottish Research Development Department. Development of a water quality index. Applied Research \& Development, Report Number ARD3, Engineering Division, Edinburg, 1976, UK, 61p.

62. Bordalo A.A., Nilsumranchit W., Chalermwat K., Water quality and uses of the Bangpakong River (Eastern Thailand). Water Research, 2001, v. 35(15), 3635-3642pp.

63. Carvalho L., Cortes R., Bordalo A., Evaluation of the ecological status of an impaired watershed by using a multiindex approach. Environmental Monitoring And Assessment, 2011, v.174(1-4), 493-508pp.

64. Liou S., Lo S., Wange S., A generalized water quality index for Taiwan. Environmental Monitoring and Assessment, 2004, v 96(1), 35-52pp.

65. Bhargava D.S., Expression for drinking water supply standards, J. Environ. Engin. ASCE 1985106(4), 757771pp.

66. Bhargava D.S., Nature and the Ganga. Environment Conservation,1987, v. 14, 307- 318pp.

67. Dwivedi S., Tiwari I.C., Bhargava D.S., Water quality of the river Ganga at Varanasi, Institute of Engineers, Kolkota, 1997, v.78, 1-4pp.

68. Smith D.G., A better water quality indexing system for rivers and streams. Water

Research

(Oxford), 1990 Vol.24 No.10 pp.1237-1244 ref.13 
69. Smith D.G., Davies-Colley R.J.: Perception of Water Clarity and Color in Terms of Suitability for Recreational Use, Journal of Environmental Management, 1992, v.36, 225-235pp.

70. Wepener V. J., Van Vuren H. J., Preez H. H. Du, The implementation of an aquatic toxicity index as a water quality monitoring tool in the Olifants River (Kruger National Park). 1992, Koedoe 42 (1), 85-96pp.

71. Wepener V., Cyrus D., Vermeulen L., O'Brien G., Wade P., 2006 Development of a Water Quality Index for Estuarine Water Quality Management in South Africa. Water Research Commission, South Africa.

72. Parmar V., Parmar K., Water Quality Index Of River Ganga: Determination Of Water Quality Index Of River Ganga In Patna District For Public Water Supply LAP LAMBERT Academic Publishing (2012-0918) 116p.

73. Ocampo D.W., On the Development of Decision-making Systems based on Fuzzy Models to Assess Water Quality in Rivers. PhD thesis, Rovira i Virgili University, Escola Tècnica Superior d'Enginyeria Química, Spain. Tarragona 2008

74. Boyacioglu H., Development of a water quality index based on a European classification scheme. Water SA, 2013, v. 33 (1), 101-106pp.

75. Boyacioglu H., Gundogdu V., Efficiency of Water Quality Index Approach as an Evaluation Tool, Ecological Chemistry and Engineering. S 2013|Vol. 20, N 2, 247255pp. 
76. Mishra N., Jha P., Fuzzy expert system for drinking water quality index. Recent Research in Science and Technology 2014, v.6(1): 122-125pp.

77. Brown R.M., Mccleiland N.J., Deiniger R.A., O'Connor M.F.A., Water quality index - crossing the physical barrier", (Jenkis, S.H. ed.) Proceedings in International Conference on water pollution Research Jerusalem, 1972, v. 6, 787-797pp.

78. Temporary Methodical instruction by a Complex Assessment of Quality of Surface and Sea water on Hydrochemical Indicators, are Enacted by the Instruction Goskomgidromet No250-1163. 1986, 5p. (in Russian)

79. RD 52.24.643-2002. The Leading Document. Methodical instructions. A Method of a complex assessment of degree of Impurity of Surface water on Hydrochemical indicators. St.Pb.: Gidrometeoizdat, 2002, 55p. (in Russian)

80. ISO 10304-1:2007, Water quality-Determination of dissolved anions by liquid chromatography of ions, Part 1 : Determination of bromide, chloride, fluoride, nitrate, nitrite, phosphate and sulfate, $15 \mathrm{p}$.

81. ISO 17294-2:2005, Water quality - Application of inductively coupled plasma mass spectrometry (ICP-MS) Part 2: Determination of 62 elements, 46p.

82. ISO 5667-1:2006, Water quality-Sampling, Part 1: Guidance on the design of sampling programmes and sampling techniques, 31p.

83. ISO 5814:1990 (E), Water quality -Determination of dissolved oxygen: Electrochemical probe method, $5 \mathrm{p}$. 
84. Manual, Guidance on chemical analysis of surface waters: Main Administration of Hydrometeorology under the USSR Council of Ministers, 1977. 542p.

85. Standard methods for the examination of water and wastewater. 20th edition USA. Edited by Lenore S. Clesceri, Arnold E. Greenberg, Andrew D. Eaton. 1998. 1.27-3.52p.

86. Sargsyan V.H., Hydrology and Hydrometry: Guideline for students of technical colleges. Yerevan, Lucky Print, 2006, 360p. ISBN 9789994197576

87. Shannon C. E., A Mathematical Theory of Communication. The Bell System Technical Journal,1948, v.27, 379p.

88. Shannon K. Works on information theory and cybernetics. M., IL, 1963, 830p.

89. Shitikov V., Rosenberg G., Zinchenko T. Quantitative hydroecology: methods of system identification. Tolyatti, IEEB RAS, 2003, 463p.

90. Simonyan A.G., Pirumyan G.P. Entropy approach to assessing the ecological status of the river. Geology of seas and oceans: Proceedings of the XXI International Scientific Conference (Schools) on marine geology. M: GEOS, v.4, 2015.

91. Margaryan G., Pirumyan E., Pirumyan G. Method for determining water quality. RA Patent, 2017, No 3204A.

92. Simonyan A.G., Pirumyan G.P., Simonyan G.S. Analysis of environmental status of the Kechut artificial reservoir and river Arpa with Armenian index of water quality.Austrian journal of Technical and Natural Sciences, "East West" 
Association for Advanced Studies and Higher Education GmbH. Vienna, 2016, No7-8, 37-40pp.

93. Simonayn A.G., Simonayn G.S., Pirumyan G.P. Analyses of environmental status of the reivers Aghstev and Getik with Armenian index of water quality. European journal of Natural History. 2016, No4, 22-27pp.

94. Simonyan G. S., Simonyan A. G., Pirumyan G. P., Systemic-Entropy Approach for Estimating the Water Quality of a River. Oxid Commun, 2018, v.41 (2), 307p.

95. Simonyan A.G., Pirumyan G.P. Analyses of the ecological status of the Pambak River using a synergistic information index. International Journal of Experimental Education. 2015, No.6, 32-34pp.

96. Simonyan A.G., Pirumyan G.P. Analyses of the ecological state of the river using a synergistic information index on the example of iver Debed. Water: chemistry and ecology. 2016, No.8 (98), 65-73pp. (in Russian)

97. Simonyan A.G. Analyses of the ecological state of the Debed river and its tributaries using the Armenian water quality index. Successes of modern natural science. 2016, No.8, 200-204pp. (in Russian)

98. Simonyan A.G. Analysis of the influence of the Akhtala river on the ecological state of the Debed river. IV International Conference on Chemistry and Chemical technology: Compendium of Materials. Institute of General and Inorganic Chemistry of the NASA RA, 2015, 272274pp. (in Russian)

99. Simonyan A.G., Pirumyan G.P. Assessment of the water quality of the tributaries of the Debed river. Collection of 
materials of a scientific conference with international participation "Modern problems of Hydrochemistry and Monitoirng of surface water quality". Part 1. Rostov-onDon, September 2015, 267-269pp. (in Russian)

100.Pirumyan G.P., Simonyan A.G. Analysis of the ecological state of the Agstev River with the help of the entropy index. Scientific Herald., 2016, No1(7), 191-195pp. (in Russian)

101.Simonayn A.G., Pirumyan G.P. Analysis of environmental status of the rivers Vorotan, Sisian and Goris. Proceedings of YSU, Series Cemistry and Biology, 2017, No 1, 12-16pp. 102.Simonyan A.G., Pirumyan G.P. Analysis of environmental status of the rivers Sisan and Goris with Armenian index of water quality. International Scientific conference "natural management and environmental protection". France (Paris), October 2016, European Journal of Natural History, 2017, No1, 70-71pp.

103.Pirumyan G.P., Simonayn A.G. Ecological stae of the Vorotan river. Scenitific Herald. 2016, No 3(9), 112-117pp. (in Russian)

104. Pirumyan G.P., Simonayn A.G. Analysis of the ecological condition of the river Arpa. Scenitific Bulletin. 2016, No 2(8), 44-49pp. (in Russian)

105.Simonayn A.G. Analysis of the environmental status of the river Voghji with Armenina index of water quality. Proceedings of YSU, Series Chemistry and Biology. 2016, No 2, 20-24pp.

106.Pirumyan G.P., Simonyan G.S., Simonyan A.G. Analysis of the water quality of the rivers Sevdjur, Kasakh and the 
Aparan reservoir using the Armenian water quality index. Scientific Herald., 2017, No2(12), 66-71pp. (in Russian)

107. Simonyan A., Simonyan G., Margaryan L., Pirumyan E., Pirumyan G. Assessment of ecological status of river with Armenian water quality index. The $6^{\text {th }}$ International Conference "Ecological\&environmental chemistry", March 2017. Abstract book. Pontos, europres, 2017, 63p.

108.Pirumyan G.P., Simonyan G.S., Simonyan A.G. Analysis of the ecological status of lake Sevan with the help of the Armenian water quality index. Scientific Herald., 2017, No1(11), 137-142pp. (in Russian)

109.Simonyan A.G., Simonyan G.S., Pirumyan G.P., Water quality assessment "Yerevan Lake" artificial reservoir. International Scientific Conference "Environmental monitoring", Italy, September 2016, European Journal of Natural History, 2017, 71p.

110.Simonyan A.G., Simonyan G.S., Pirumyan G.P., Analysis of environmental status of the Kechut artificial reservoir. International Scientific Conference "Ecology industrial regions of Russia", Great Britain, October 2016, European Journal of Natural History, 2017, 69-70p.

111.Simonyan, G.; Pirumyan, G. Entropy - System Approach to Assess the Ecological Status of Reservoirs in Armenia. Preprints 2019, $2019010260 \quad$ (doi: 10.20944/preprints 201901. 0260. v.1).

112.Derdzyan T.H., Pirumyan G.P. hydro-chemical research of water of "Yerevan Lake" artificial reservoir. Academic Journal of Science. USA, 2013, v.2, No2, 339-344pp. 
113.Derdzyan T.H.,Margaryan L.A., Minasyan S.H., Pirumyan G.P. Hydrochemical study of freshwater large reservoirs in Armenia and water quality assessment using index methods. Water: chemistry and Ecology. 2014, v.1, 97-101pp.

114.Derdzyan T.H., Simonayn G.S., Pirumyan G.P. Analysis of the ecological state of the large reservoirs in RA using synergic theory of information. Abstract book on Current trends in science and education, Warsaw, 2014, 33-39pp.

115.Derdzyan T.H., Pirumyan G.P. Investigation water quality of the reservoirs located at the north-west part of Armenia 2006-2009. Materials of All-Russian Scientific Practical Conference "Ecological Safety and Nature Management: Science, Innovation, management", Makhachkala, 2013, 8791pp.

116.Derdzyan T.H., Pirumyan G.P. Assessment of the water quality of "Yerevan Lake" artificial reservoir for 2005-2009 using index methods. Abstract book of YSU, Yerevan 2012, v. IV (47), 111-115pp.

117.Derdzyan T.H., Margaryan L.A., Minasyan S.H., Pirumyan G.P. Hydrochemical study of "Azat" artificial reservoir and water quality assessment using index methods. Water: chemistry and Ecology. 2012, v.3, 105-109pp.

118.Derdzyan T.H., Margaryan L.A., Pirumyan G.P. Study of water pollution level of "Azat", "Ketchut", "Yerevan lake", "Akhuryan", "Lake Arpa" and "Aparan" artificial reservoirs. Water: chemistry and Ecology. 2012, v.9, 95100pp.

119.Derdzyan T.H., Margaryan L.A., Minasyan S.H., Pirumyan G.P. Investigation of pollution of Lake Arpi, Akhuryan and 
Aparan reservoirs. Information Technology and Management, 2008, v.8, 127-131pp.

120.Derdzyan T.H., Margaryan L.A., Pirumyan G.P. Hydrochemical study of "Yerevan Lake" artificial reservoir. Water and Ecology. 2009, v.4 (41), 43-46pp.

121.Derdzyan T.H., Pirumyan G.P. Investigation of water pollution level of "Yerevan Lake" artificial reservoir. Monitoring of natural ecosystems. Abstract book of III International conference. Penza, 2009, 105-108pp.

122.Derdzyan T.H., Margaryan L.A., Pirumyan G.P. Quality assessment of Kechut reservoir water by index methods. A Collection of Works of II International Conference of Goris State University. Goris, 2011, 239-253pp.

123.Pirumyan G.P., Simonyan A.G. Analysis of the ecological state of the river with the help of background concentrations. Scientific Bulletin. 2016.N 4 (10), 105110pp. (in Russian)

124.Talanov V.A. Mathematical models for the synthesis of peptide chains and methods of graph theory in deciphering genetic texts.

http://new.math.msu.su/department/dm/dmmc/PUBL1/gen.htm

125.USAID, Technical Approaches for incorporating climate change into hydrological analysis. "Clean Energy and Water Program" Report, 2012, 49p.

126.Rygg B., Indicator species index for assessing ecological quality in marine waters of Norway. 2002, In: NIVA report 4548p.

127.Borja A., Franco J., Perez V., A marine Biotic Index to establish the ecological quality of soft-bottom benthos 
within European estuarine and coastal environments. Marine Pollution Bulletin, 2000, No 40, 1100-1114pp.

128.Borja A., Josefson A.B., Miles A., Muxika I., Olsgard F., Philips G., Rodriguez J.G, Rygg B., An approach to the intercalibration of benthic ecological status assessment in the North Atlantic ecoregion, according to the European Water Framework Directive. Marine Pollution Bulletin, 2007. v.55, 42-52pp.

129.Borja A., Muxika I., Franco J., The application of a Marine Biotic Index to different impact sources affecting softbottom benthic communities along European coasts. Marine Pollution Bulletin, 2003. No46, 835-845pp.

130.Puente A., Diaz R.J., Is it possible to assess the ecological status of highly stressed natural estuarine environments using macro invertebrates indexes? Marine Pollution Bulletin, 2008. No56, 1880-1889pp.

131.Rygg B., Developing indexes for quality-status classification of marine soft-bottom fauna in Norway. 2006, In. NIVA report 5208p.

132.Vannportalen, 2009. Klassifiserings Veilder In., www.vannportalen.no

133.Rosenberg R., Blomqvist M., Nilsson H.C., Cederwall H., Dimming A., Marine quality assessment by use of benthic species-abundance distributions: a proposed new protocol within the European Union Water Framework Directive. Marine Pollution Bulletin, 2004. v.49, 728-739pp.

134.Nilsson H.C., Rosenberg R., Succession in marine benthic habitats and fauna in response to oxygen deficiency: 
analysed by sediment profile-imaging and by grab samples. Marine Ecology-Progress Series, 2000, v.197, 139-149pp.

135.Parson T.H., Roesnberg R., Macrobenthic succession in relation to organic enrichment and pollution of the marine environment. Oceanography and Marine Biology an Annual Review, 1978. v. 16, 229-311pp.

136.Denisenko S.G., Structurally-functional Characteristics of the Barents Sea Zoobenthos. Proc Zool Inst Russ Acad Sci, 2004, v.300, 43p.

137.McArthur R. M., Fluctuation of Animal Populations and Measure of Community Stabiliry. Ecology, 1955, v.36 (3), $533 \mathrm{p}$.

138. Margalef R. Information theory in ecology. Gen. Syst. 1958,v. 3, 36-71pp.

139.Margalef R., La teoria de la information en ecologia. Mem Real Acad Cienc Y Artes Barcelona, 1957, v.32, 373p.

140.Schmalhausen I.I. Cybernetic questions of biology. Novosibirsk, Science, 1968. 224p.

141.Ivanova T.V., Kalinova G.S., Myagkova A.N. General biology. M., Enlightenment, 2000. 460p.

142.Nikolaev A.Ya. Biological chemistry. M, MIA,2001. 496p.

143.Simonyan G.S, Simonyan A. G. Entropy approach to the assessment of chaos and the order of biological systems. Successes of modern natural science. 2015. №9. 100-104pp. (in Russian)

144. Simonyan G.S., Simonyan A. G., Sayadyan M. L., Sarsekova D. N., Pirumyan G. P. Analysis of Environmental Status of Wood and Shrub Vegetation by the 
Armenian Index of Environmental Quality. Oxidation Communications 2018, V.41, No 4, 533-541pp.

145.Sayadyan M.L. Colection of plant species: Ijecan subtropical arboretum.Vanadzor: SIM Press. 2010, 204 p.

146.Pavlov N.V., Smolyanov A.S., Weiss A.A. Mathematical methods in forestry. Krasnoyarsk: SibSTU, 2005. 192 p. (in Russian)

147.Simpson E.H.: Measurement of diversity. Nature, 1949. V.163, 688p.

148.Hill M. O. Diversity and Evenness: a Unifying Notation and Its Bioconsequences. Ecology, 1973. V.54, 427p.

149.Jost L. Entropy and Diversity. Oikos, 2006. V.113, 363p.

150.Askharova M.A., Arslan M., Mussagaliyeva A.N., Environmental Security of Geosystems of Kazakhstan. State and Evaluation. Oxid Commun, 2014, v.37 (3), 882p.

151.Simonyan G.S. Elemental and chemical composition of oil. Technique and technology of the XXI century: Monograph. Book 4 / under total. ed. I. B. Krasinoy - Stavropol: Logos, 2015.170-189 pp. (in Russian)

152. Simonyan G.S. Endogenous formation of naftids in the light of the abiogenic theory of oil formation. Scientific Review. Technical science. 2016. No. 4., 77-100pp. (in Russian)

153.Kudryavtsev N.A. Genesis of oil and gas. L.: Nedra, 1973. 216pp. (in Russian)

154.Gubkin I.M. The doctrine of oil. M: Science, 1975. 387p. (in Russian)

155.Gold $\mathrm{T}$. The origin of natural gas and petroleum, and the prognosis for future supplies. Ann. Rev. Energy.1985.V. 10. 53-77pp. 
156. Timurziev A.I. The October Theses, or the Beginning of the Second Stage of Preparing the Scientific Revolution on Changing the Paradigm of Oil and Gas Geology in Russia. Subsoil Use XXI Century.1917, No. 1. 116-121pp. (in Russian)

157.Timofeev D.N. The nature of the cosmic bodies of the solar system. Krasnoyarsk: City, 2018. 227p. (in Russian)

158.Simonyan G.S., Pirumyan G.P. The role of nitrogen in the endogenous formation of oil. Modern science: actual problems and development prospects: monograph. Book 4. Stavropol: Logos, 2014. 84-100pp. (in Russian)

159.Simonyan G.S. The role of nickel and vanadium metalloporphyrins in the abiogenic formation of oil. Modern high technologies. 2015.№ 9. 82-85pp. (in Russian)

160.Simonian G. Chemical processes of abiotic oil formation. GISAP: Physics, Mathematics and Chemistry. 2015, No. 7. 10-13pp.

161.Simonyan G.S. Prospects for obtaining metals from oil "Innovative technologies and projects in the mining and metallurgical complex, their scientific and personal support" Collection of works of the International Scientific and Practical Conference. Ch. ed. Zh. M. Adilov. Almaty: KazNTU, 2014. 446-449pp. (in Russian)

162.Simonian G., Beylerian N. Michaels condensation in conditions of inverse transfer catalysis. Kinetic study. In:Success in Chemistry and Biochemistry Ed.G.E.Zaikov. Nova Sci.Pub.Inc. New-York, 2009, v.33, 445-452pp.

163. Simonian G. S., Pirumyan G. P. Reactions of unsaturated surfactants with methylethanolamine in the model oil-water 
system. Russian Journal of General Chemistry.2014, V.84, № 13, 2552-2554pp.

164.Simonyan G.S. Fractality of oil deposits and oil. Oil and gas technology. 2015. №3, 24-31pp. (in Russian)

165.Simonyan G.S. Analysis of the state of naphtide systems in the light of the synergistic information theory. Modern high technologies 2014, No.4, 108-113pp. (in Russian)

166. Simonian G. Analysis of the state of geoecological systems in the view of synergetic theory of information. GISAP: Physics, Mathematics and Chemistry. 2014. №4. 18-21pp.

167.Simonyan G.S. Maturity assessment of oil deposits using the entropy index "Modern problems of oil and gas geology" Kiev: Institute of Geological Sciences of the National Academy of Sciences of Ukraine, 2016, 135137pp. (in Russian)

168. Simonyan G.S. Analysis of the state of naphtide systems in the light of the synergistic information theory. Modern high technologies 2014, No.4, 108-113pp.

169.O.V. Baratashevich et al . Geochemical methods for finding oil and gas fields. M .: Nedra, 1980. 300 p. (in Russian)

170.Yu.R. Kagramanov On the problem of the prospects for the oil and gas potential of the Ararat-Aragats basin. Yerevan: Asogik, 2010.141p. (in Russian)

171.Simonyan G., Pirumyan E., Margaryan L Grigoryan S, Pirumyan G. Oil Field Detection Method. RA Patent, 2012, No 2682A. 


\title{
G. PIRUMYAN, G. SIMONYAN, L. MARGARYAN
}

\author{
GEOECOLOGICAL EVALUATIONAL \\ INTEGRATING INDEX OF NATURAL \\ WATERS AND OTHER SYSTEMS
}

Computer design: Karine Chalabian

Signed for publication 12.08.2019.

Format 60x84 1/16. Singnature 15.125.

Circulation 300.

CopyPrint LTD 
